
Digitized by the Internet Archive in 2007 with funding from Microsoft Corporation 






\section{A MONOGRAPH

\section{THE MYXOGASTRES.}

BY

GEORGE MASSEE.

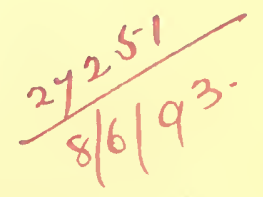

ftlettuten \& $\mathbb{C} \mathfrak{a}$, 18, BURY STREET, LONDON, E.C.

1892. 
Riciard Clay a sons, Lamitro, Losmox \& Btruar. 


\section{PREFACE.}

THE preparation of a monograph dealing with minute organisms, where the descriptions of the old authors are comparatively or often absolutely valueless, depends on the facilities afforded for a critical examination of type or authentic specimens. In this respect I have enjoyed exceptional facilities. The splendid collection of Myxogastres in the Royal Herbarium, Kew, rich in types, and with numerous annotations by Rostafinski, who examined the collection in detail, and which indeed served as the basis for his excellent monograph, also served me in like manner. To other workers in the same field in different countries I am also indebted for the loan or gift of valuable, and in some instances unique, specimens. To all who have in this or other ways assisted, I offer my sincere thanks.

Notwithstanding the excellent work initiated by the late Professor De Bary, and continued by Brefeld, Cienkowski, Woronin, Zopf, and others, the life-history of the majority of forms is still unknown; hence all attempts at classification, as also the conception as to what constitutes a species, must be considered as tentative. When we are better aquainted with the main lines of development and lines of variation, also the conditions determining these variations, it is certain that the main factor in the discrimination of species will not be a onetwelfth oil-immersion objective.

Geo. MasseE.

Kew, 1892. 


\section{MONOGRAPH OF THE MYXOGASTRES.}

\section{HISTORICAL.}

NeGLeCTING the allusions made to members of the present group by the pioneers of science, we find amongst the earliest of unmistakable accounts, an essay on the organism popularly known as "Flower of $\tan$ "-Fuligo varians, Rost., by Marchand, a Frenchman. ${ }^{1}$ The account, as would be expected, savours of the mysterious; but it is evident from the name used, 'Eponge,' and from certain remarks made, that the author considered the organism as being most nearly allied to what are at present considered as members of the animal kingdom. From this period until within the last thirty years, the Myxogastres have almost universally been considered as fungi, and with but few exceptions regarded as belonging to the Gastromycetes.

Characteristic figures by early authors occur in the works of Micheli, ${ }^{2}$ Gleditsch, ${ }^{3}$ Schaeffer, ${ }^{4}$ Bulliard, ${ }^{5}$ Sowerby $_{3}{ }^{6}$ and Schrader. ${ }^{7}$ Fries was the first to clearly grasp the leading features of the group to which he gave the name of Myxogastres, and defined as follows, "Primitus mucilaginosi, fluxiles." 8 In

1 Sur une végétation particulière qui vient sur le tan, Hist. de l'acad. roy. des sciences, Paris (1727).

2 Nov. Plant. Gen. (1729).

4 Icon. Fung. (1762).

- Engl. Fung. (1797-1809).

8 Syst.: Myc., iii. p. 67 (1829).

3 Meth. Fung. (1753).

5 Hist. Champ, France (1791-1798).

7 Schrad., Nov. Gen. (1797). 
the Friesian arrangement of fungi, the Myxogastres constitute one of the two sub-orders of the Gastromycetes, a position that was perfectly justifiable when we remember that at the period in question, external resemblances were accepted as proofs of affinity; and considering the advances made in almost every other group of minute organisms due to microscopic research, it is somewhat remarkable to find that until the year 1864 the classification of the Myxogastres was based almost entirely on naked eye, or at most, pocket-lens characters. At the date last named, the appearance of Professor De Bary's splendid work on the present group ${ }^{1}$ completely revolutionized all the pre-existing ideas as to structure and affinity, and has served as the basis upon which all subsequent writers have endeavoured to demonstrate kinship amongst the various sections comprising the group.

\section{Affinitics.}

Respecting the nature and affinities of the Myxogastres, we find the following in Professor De Bary's last work on the subject-"I have, since the year 1858, placed the Myxomycetes under the name of Mycetozoa outside the limits of the vegetable kingdom, and I still consider this to be their true position." ${ }^{2}$ This statement has been generally interpreted, and probably correctly, as signifying that De Bary looked upon his Mycetozoa as animals; but it would perhaps have been wiser to have stated this belief point-blank, and to have chosen some other word than Mycetozoa to designate the group, thereby dispelling any lingering of doubt as to his meaning. The difficulty is not lessened by De Bary's introductory paragraph on the Mycetozoa, which is as follows-"The name Mycetozoa is here applied to a group of fungus-like organisms amounting at the present time to nearly three hundred species, the larger number of which are contained in the division Myxomycetes or Slime-Fungi (the Myxogastres of Fries), together with the smaller one distinguished by Van Tieghem under the name of Acrasieae.

1 Die Mycetozoen (Schleimpilze), (1864).

2 Fungi Mycetorua and Bacteria; Engl. ed., p. 444. 
"The resemblance of the Mycetozoa to the Fungi is due partly to their mode of life and nutrition, partly to the close agreement in structure and biological characters between their organs of reproduction and the spores of Fungi. A spore-terminology corresponding to that of the Fungi will therefore be applied to the present group." ${ }^{1}$ In the Myxogastres, the life of an individual consists, under normal conditions, of two very sharply defined stages; first, the vegetative phase, concerned with functions tending towards the well-being of the individual; second, the reproductive phase, concerned entirely with the continuation of the species. The above quotation not only shows that De Bary's reasons for placing the Myxogastres in the animal kingdom are derived entirely from the vegetative phase, but what is equally important to note, that the disparity between the reproductive phase in the Myxogastres and that exhibited by any of the lower groups of animals is so great, while "the close agreement in structure and biological characters between their organs of reproduction and the spores of fungi" are so pronounced, that De Bary was compelled to adopt the terminology used by fungologists in describing all the parts belonging to the reproductive phase, and not only the spores; such terms as sporangium, capillitium, columella, \&c., are used by fungologists for structures in fungi that are identical in function with the structures designated by the same names by De Bary in the Myxogastres.

Passing to the evidences of affinity afforded by the vegetative phase, we find De Bary's idea on this point expressed in the following quotation-

"The group of the Mycetozoa differs distinctly from the Fungi which have been the subject of the first part of this book in all such characteristics as do not belong to all organisms alike, and the descriptions already given of both kinds of plants render any further explanation of the point unnecessary; their connection also with other known plants is still more remote. The difference would not be less decided if the Mycetozoa were without their remarkable movements, for such movements are

1 Tom. cit. p. 421. 
observed in other vegetable cells which have not a firm membrane. The characteristic mark of separation lies in the formation of plasmodia or aggregation of swarm-cells."

We find in the abuve paragraph the reasons why the Myxogastres are placed outside the vegetable kingdom; these reasons we further find to be two in number-one general, the other specific. Commencing with the general reason, "The group of the Mycetozoa differs distinctly from the Fungi . . . in all such characteristics as do not belong to all organisms alike." In estimating the value of the above reason, it will be most satisfactory to accept De Bary's own idea as to what constitutes a standpoint for comparison, which is as follows-" We find it impossible to establish any strict homologies, and we are limited to the observation of resemblances in form, structure, and mode of life." 2 As stated above, the Myxogastres are so far differentiated as to have the vegetative and reproductive plases sharply defined, and it is customary, I believe, to take the sum of characters presented by both phases, in determining affinities; hence while admitting that reproduction is common to all organisms alike, I maintain that differences of degree in connection with reproduction, are also of value in determining affinities, and consequently cannot reconcile "the resemblance of the Mycetozon to the Fungi is due partly to their mode of life and nutrition, partly to the close agrecment in stmucture and biological characters between their organs of reproduction and the sporcs of Fungi"-(the italics are ours)-with "the group of the Mycetozon differs distinctly from the Fungi . . . in all such charactcristics us do not belong to all organisms alike"(italics ours) - especially as De Bary admits that in such simple groups, our proofs of affinity are "limited to the observation of resemblances in forms, structure, and mode of life."

Second, or specific reason.-- "The characteristic mark of separation lies in the formation of plasmodia or aggregation of swarm-cells."

To realize the true value of the two points, both presented by the vegetative phase, and considered by De Bary as of sufficient

1 Tom. cit. p. 443.

2 Tom. cit. p. 443. 
importance to place the Mycetozoa outside the vegetable kingdom, tile formation of a plasmodium in the Myxomyeetes, or the aggregation of swasm-cells in the Acrasicae, the two primary divisions of the Mycetozoa, it is necessary to commence with the germination of the spore. In the Myxomycetes, the spores on germination give origin to one, two, or more naked cells, which possess the power of movement due to the protrusion of pseudopodia or the presence of a cilium; these cells are known as swarm-cells. The swarm-cells possess a nucleus, multiply by bipartition, and eventually coalesce to form a plasmodium in the following manner. After the production of numerous swarm-spores by repeated bipartition, little groups are formed by the close approach of two or more of these bodies; these groups often disperse again, but eventually the components of a group coalesce, and lose their individuality; this coalescence and loss of individuality results in the formation of a small plasmodium, which, in some unknown way, possesses the power of attracting surrounding free swarm-cells; these at once coalesce and add to the bulk of the plasmodium. The nuclei of the component swarm-cells retain their individuality in the plasmodium, the latter retaining the power of motion originally possessed by its components, and represents the vegetative phase of a Myxogaster. The above is De Bary's conception of the formation of a plasmodium, to which may be added, in his own words-" Nuclei were not at first observed in the plasmodia. Cienkowski even stated expressly that the nuclei present in the swarm-cells disappear when they coalesce. But Schmitz and Strasburger have recently established the presence of numerous nuclei in the plasmodium, and it may be presumed that they are the persistent nuclei of the swarm-cells and products of their division." I The presence of a thick, colourless membrane surrounding the plasmodia in Lycogala, Areypia punicea, and Stemonitis fusca has been noted by De Bary, who also found that in the last-named species, the inner and thicker portion of the envelope became blue with iodine. Under certain conditions unfavourable for active vegetative work,

1 Tom. cit. p. 425. 
plasinodia possess the power of passing into a temporary sclerotioid or resting stage; the preliminaries for this condition are the breaking up of the protoplasm into innumerable roundish or polyhedric cells with an average diameter of from $25-40 \mu$. In some species, as Fuligo and Didymium scrpula, the cells become surrounded by a distinet, colourless membrane, which shows the reaction of cellulose with iodine and sulphuric acid or with Schulze's solution.

In the Acrasicce, the spores on germination give origin to ameboid swarm-cells, ciliated cells never being produced; after undergoing repeated bipartitions, the swarm-cells form dense masses, but although crowded together, do not coalesce; this crowding together without loss of individuality constitutes what De Bary terms, aggregation of swarm-cells.

From the above account we learn that the coalescence of naked, motile cells, or even the aggregation of naked motile cells without loss of individuality, is, from De Bary's standpoint, the proof that the Myxogastres are not plants.

Naked or primordial cells are as a rule motile; in fact a considerable amount of motility is usually exhibited by protoplasm when imprisoned in a cell-wall; hence we may presume that motility, being so general, is not an important factor in the character that proves Myxogastres to be animals; in fact De Bary admits that the differences between the Mycetozoa and the Fungi "would not be less decided if the Mycetozoa were without their remarkable movements, for such movements are observed in other vegetable cells which have not a firm membrane." The Acrasicae show that the coalescence, with loss of individuality of the component cells, may be omitted from the character that separates the Myxogastres from plants; hence we find that the only point not neutralized by De Bary's own statements is that of naked cells; consequently we may, by following De Bary's reasoning, formulate the character that excludes the Myxogastres from the vegetable kingdom as follows-Cells naticd during the entive vegetative period.

Notwithstanding the fact that the above definition covers 
the crucial point in De Bary's characteristic work of separation, which "lies in the formation of plasmodia or aggregation of swarm-cells," it will be well to treat individually, all the points embodied in the original, commencing with the coalescence of cells. This coalescence, and consequent loss of individuality of cells to form a common mass of protoplasm capable of spontaneous movement, is the leading characteristic of a plasmodium; but it is an undoubted fact that motility is to a very considerable extent influenced by the presence or absence of a cell-wall, or to the relative plasticity of the cell-wall when present; and coalescence of protoplasm, even when cell-walls intervene, is highly characteristic of fungi, and has received different names depending on its supposed morphological or physiological functions; it is sufficient to name "clamp-connections" characteristic of the vegetative hyphae of the Basidiomycetes; and the complex irregular network formed by the vegetative hyphae of many of the forms included in the Hyphomycetes as being due - to the fusion of portions of protoplasm originally distinct. In the above examples the component hyphae are septate; but in the Mucorini, where the hyphae are entirely without septa, there is a still nearer approach to a plasmodium.

In the last-named group, the spore on germination gives origin to an intricately branched mycelium, the component branches of which eventually form a dense, irregular network, due to the numerous points at which coalescence of originally distinct branches has taken place. If single spores, picked up under a low magnifying power, on the point of a needle touched with glycerine, are sown on glass slips in a thin smearing of sterilized decoction of raisins, covered with large squares of thin glass sterilized by passing through the flame of a spirit-lamp, raised at one end by a strip of tracing-paper to prevent crushing the spore, and at once sealed up with cement, it will be found that in most cases, spores of the Hyphomycetes or Phycomycetes will germinate at once, and continue to grow until a considerable mass of mycelium is formed; such preparations can be examined at any moment under high powers without loss of time, and the behaviour of the mycelium followed. A noteworthy feature 
presented during the growth of the primary mycelium is the gradual tapering of the hyphae; this tapering is of a two-fold nature; the main trunk, or first portion emitted by the spore produces secondary thinner branches, these in turn bear still thinner branches, and this production of successively thinner hyphae results in a complex structure, which may be compared to the branching of a tree, commencing with the trunk and ending with the youngest and thinnest ramifications. The second type of tapering is seen in the gradual attenuation of the component hyphae; this is most conspicuous in the case of elongated, unbranched hyphae, which from a basal width of $8-10 \mu$ taper gradually towards the apex, which may not exceed $2 \mu$ in width. If a spore of Mucor lateritius, a species met with on semi-putrid potatoes, be sown on a glass slip in a drop of sterilized decoction of decayed potato, and kept in a damp atmosphere under a small bell-jar, growth proceeds somewhat as described above; a dense mycelium showing the two aspects of attenuation is developed; and as growth proceeds an irregular reticulation is formed, due to the coalescence of originally distinct lateral brauches. This coalescence is not confined to cases where two hyphae happen to meet in the ordinary course of growth, but in many instances, as described in detail by Professor Marshall Ward in the instance of a species of Botrytis, ${ }^{1}$ the hyphae attract each other, and may be deflected from their previous course through a right angle or even more. The peripheral hyphae usually elongate for some distance in straight lines, the unknown factor in connection with coalescence being apparently absent from the youngest portions, and only manifests itself at some distance behind the tips of the hyphae, where it possibly determines first the origin of lateral branches, and subsequently their direction. This yearning for coalescence is not common to all lateral branches. The hyphae possess a cell-wall but no transverse scpta, hence the protoplasm is continuous throughout the intricate mycelium, and, as would be expected, the cell-wall is exceedingly thin and yielding, and becomes very pale blue with iodine, and very pale brownish-

1 A lily-disease. Amals of Botany, vol, ii. pp. 319-378, 5 plates. 


\section{A Monograph of the Myxogastres.}

purple with cellulose reagents. After the vegetative mycelium has acquired a certain amount of reserve material, one or more of the thickest portions give origin to yet thicker branches which grow erect; each erect branch at length becomes dilated into a large sphere at its apex; into this sphere a considerable amount of protoplasm, obtained from the vegetative mycelium, becomes concentrated, and retained by the development of a transverse septum at the base of the sphere where it passes into its support. After these preliminaries, the reproductive phase may be said to commence, the protoplasm undergoes differentiation, resulting in the separation of lime which appears in the form of a thin frosting outside the wall of the sphere or sporangium; another portion of the protoplasm becomes differentiated into the broadly elliptical conidia or spores; while a third portion of the protoplasm, which may be considered as of no value in the process of spore-making, remains in the form of very thin, irregular strands in what may be termed the

- intercellular spaces between the spores. Most species of the Phycomycetes and Mucorini pass through the above phases during their development, differing in minor points, as form of conidia, presence or absence of lime on sporangia, \&c. The above description covers many points in the development of a typical member of the Myxogastres. The latter differ at the starting-point in the first product of germination, being more motile than in Mucor, after coalescence of the cells to form a plasmodium; the latter usually behaves somewhat similar to the mycelium of Mucor, advance of the mass being effected by the protrusion of long tapering strands which at some distance behind the tips coalesce to form a dense, irregular network; every portion of a plasmodium, even the thinnest outlying strands, are furnished with a distinct, thin, yielding membrane, analogous at least to the membrane called the cell-wall, protecting the protoplasm in the Mueor mycelium; the two membranes agree in origin, being secreted by the protoplasm; both become blue with iodine, and pale dirty brownish-violet with " chlor-zinc iodide." The reproductive phase consists in the conversion of certain portions of the protoplasm into erect sporangia with the 
apical portion usually more or less globose; the membrane of the plasmodium is continued upwards to form the wall of the stem and sporangium, the protoplasm of the plasmodium passes into the newly formed sporangia, undergoes differentiation frequently resulting in the separation of lime which may form a crust outside the sporangial wall; spores are differentiated, and generally a surplus portion of the protoplasm takes the form of a more or less complicated network mixed with the spores, and homologous with the strands described as being present in the sporangium of Mucor, inasmuch as both structures are made from a substance separated from protoplasm during sporcformation; finally, the cell-wall of the spores of the Myxomycetes agrees with that of the spores of fungi in giving a cellulose reaction when young; as differentiation of the wall proceeds, in common with the spores of fungi, mosses, and ferns, the cellulose reaction is no longer obtained, except perhaps in the inner layers. The above comparison between Mucor and the Myxomycctes is not introduced with the vicw of showing close homologies, but to draw attention to what I consider may, at least, be accepted as a series of analogies, which, accepting De Bary's opinion, would, in the present connection, indicate affinities, as we find it formulated that in searching for affinitics, "we find it impossible to establish any strict homologies, and we are limited to the observation of resemblances in form, structure, and mode of life."

I regret to say that I am not sufficiently familiar with the lower forms of animal life to indicate any group presenting an equal number of analogous points with the Myxomycetes, as have been described above in the fungi belonging to the Mucorini, otherwise I should be too pleased to do so; it is not my desire to endeavour to force the Myxogastres into filling a preconceived gap in the vegetable kingdom, but simply to analyze the reasons advanced in favour of their exclusion from the plant world; personally it is not a matter of prime importance whether it be eventually shown that I have been a botanist or a zoologist. It is admitted by De Bary that the wall or membrane of plasmodia, the cell-walls of spores, and various other structures 
belonging to different orders of the Myxogastres, give a characteristic cellulose reaction, and more extended experiments were only required to show that the presence of cellulose during some or other phase of development is general in the Myxomycetes; cellulose as a protective substance cannot be said to be so generally present as in phanerogams, neither is it so general in the fungi, henee the term fungus-cellulose. In the Acrasicae the stipes in many species consists of one or more rows of superposed cells having the walls composed of cellulose.

The presence of eellulose, according to De Bary, is the only character showing that the Myxogastres are in touch with the vegetable kingdom-" The Mycetozoa show only a slight agreement, either in the general course of their development or in the characteristie features of its separate stages, with organisms that are of undoubted vegetable origin; whether they be fungi or plants other than fungi; the agreement, with the exception of a few cases in which cellulose makes its appearance, is eonfined to phenomena which are common to all organized bodies." 1

I eannot reconcile the above sweeping statement with the two following, first-in connection with affinities, "we are limited to the observation of resemblances in form, structure, and mode of life"; second, "the resemblance of the Mycetozoa to the Fungi is due partly to their mode of life and nutrition, partly to the close agreement in structure and biological charaeters between their organs of reproduction and the spores of Fungi." One more point given by De Bary in support of the animal nature of the Myxogastres requires to be noticed. "It is obvious moreover aecording to our present knowledge that the Mycetozoa are the superior terminal member or the two terminal members of a series of forms or developments which commence elsewhere. The most highly differentiated sections of the group, the Calcareae, Trichiae, Lyeogala, and others, give evidence of no close affinity with any more highly differentiated group; in other words, like the Gastromycetes with which they were classed by earlier botanists, they do not connect with any group above

1 'Tom. cit. p. 444. 
them. Hence in inquiring after their affinities we must be content with searching for a possible connection with an inferior group, and for the simpler forms from which they have proceeded.

"When we seek for such a connection among the forms with which we are acquainted, we find it impossible to establish any strict homologies, and we are limited to the observation of resemblances in form, structure, and mode of life. Such a course of unprejudiced comparison leads us by a very short step to the naked 'Amoebae' of the zoologists, especially in Bütschli's sense, as the starting-point, organisms with bodies having the amoeboid movements of the swarm-cells of the Myxomycetes, which multiply, as far we at present know, by successive bipartitions without forming plasmodia, and which inay pass singly and without aggregation or coalescence into states of rest not essentially different in their characteristics from those of the spores of the Myxomycetes." 1

Undoubtedly the Myxogastres must be considered as a terminal group, and the very fact of this admission implies a certain amount of differentiation, in fact sufficient to give individuality to the group. I accept De Bary's reasoning as to the origin of the Myxogastres, and as an evolutionist am ready to extend the same reasoning to other groups, as having had a common origin from the lowest forms of life, where, owing to absence of differentiation, the ideas implied in the terms animal and vegretable respectively are not evolved, and I consider that the entire evidence as to the animal or plant tendency of any departure from this neutral starting-point consists of the aggregate tendency of the evolved features which collectively constitute the charateristics of the group under consideration; and this tendency as manifested by the Myxogastres I consider to be in the direction of the vegetable kingdom, and more especially in the direction of the Fungi, for the following reasons, which, keeping in view the fact that we are dealing with a terminal group, and consequently can draw no comparisons from higher forms of the same type, "we find it impossible to establish any

1 Tom. cit. p. 443. 
strict homologies, and we are limited to the observation of resemblances in form, structure, and mode of life."

1. Frequent presence of cellulose in the general membrane protecting plasmodia, cell-walls of spores, sporangia, and walls enclosing the protoplasm in the sclerotioid or resting stage of plasmodia.

2. Presence of germ-pores in the cell-walls of the spores, of some species.

3. The frequent separation of lime from the protoplasm at the commencement of the reproductive phase.

4 . In the frequent separation of a substance from the protoplasm during the period of spore formation, homologous with the substance separated during the same period in the Ascomycetes, Mucorini, \&c. This substance in the Myxogastres forms the capillitium.

5. The agreement with many fungi in the contrivances for spore dissemination.

6. The production by free cell-formation of spores protected in the early stage with a wall of cellulose, which eventually becomes differentiated, and as stated by De Bary, "behaves towards reagents in a similar manner to cuticularized plantcell-membranes and to spore-membranes as in the Fungi." 1

7. Presenting analogy with undoubted members of the vegetable kingdom, as Hydrodictyon, where the naked, motile swarm-cells coalesce to form a coenobium which eventually becomes invested with a membrane.

8. In the close affinity with the genus Ceratium, where we trace the sequence which leads to what is morphologically a mycelium furnished with transverse septa. In Ceratium the spores do not originate by free-cell-formation within a sporangium, but are produced after the manner of the spores of the Basidiomycetcs or the conidia of the Hyphomycetcs. The general course of development in all the species, so far as can be determined from herbarium specimens, agrees with that of Ceratium hydnoides as described by Famintzin and Woronin, ${ }^{2}$ the specific

1 Tom. cit. p. 441.

2 Mem. Acad. Petersburg, XX, No. 3 (1873). 
distinctions depending more especially on the mode of branching and colour. The point of interest in the present connection is the mode of spore formation. Without entering into details, the protoplasm, immediately preceding spore formation, becomes arranged on the branches as a peripheral layer of cells enclosed in cellwalls, which, in the case of Cratium hydnoides, give a cellulose reaction when young. Owing to local growth, the central portion of the free side of each cell grows outwards in the form of a slender elongated cylinder until it measures about $10 \mu$ in length by about $3 \mu$ in diameter; the next change consists in the expansion of the free end of this outgrowth which continues until it assumes in C. hydnoides, a broadly elliptical form, about $10 \times 6-7 \mu$ in size; into this swollen apical portion the whole of the protoplasm then passes through the stalk from the parent cell, after which a transverse septum is formed in the stalk-like portion close up to its swollen apex, which eventually breaks away at the septum as a mature spore. In C. hydnoides the stalks persist after the spores have fallen away, each closed at the apex by the septum which formed the line of dehiscence, and the homology with the formation of conidia or spores in the Basidiomycetes is perfect. In each case we find a cell richly supplied with protoplasm giving origin by local growth to one or more thin spine-like processes, each of which becomes much enlarged at its apex; into these enlarged portions all the protoplasm from the mother-cell becomes concentrated and retained by the formation of a septum across the stalk close to the swollen apex, which eventually falls away at the septum as a ripe spore. The first appearance of a transverse septum being for the purpose of isolating a mass of protoplasm concentrated for purposes directly concerned with reproduction suggests the iden, if nothing more, that the Myxogastres are in touch with other acknowledged members of the vegetable kingdom. The remaining species of Cerativon show the same mode of spore formation, but in C. arbuscula, B. and Br., a very fine muchbranched species, the thin outgrowth bearing the spore at its apex is much larger than in C. hydnoides, and the transverse septum is even more distinet, while in C. filiforme, $\mathrm{B}$. and $\mathrm{Br}$., the 
slender stalk-like outgrowth measures from $18-20 \mu$ in length, and after having become inflated at the apex and absorbing the protoplasm from the parent cell, is cut off from the latter, first by a septum close to the parent cell; this is followed by the formation of a second septum close to the base of the swollen apical portion or spore.

9. In the coalescence of the naked cells to form a plasmodium being the result of conjugation between the component cells, thus presenting features in common with the primitive forms included in the group Zygosporeac. The reasons for the above statement are as follows-The frequent occurrence of forms intermediate between well-marked, but closely allied species, suggested the idea of hybridity, especially as the supposed hybrids varied in their degree of morphological agreement with one or other of the two species between which they were intermediate. With the object of ascertaining whether hybrids were formed in nature, the young plasmodia of Physarum leucopus and Physarum leucophaeum were so placed that the plasmodia of the two became blended together at the point of contact; this experiment resulted in the formation of sporangia intermediate between the two species from the blended portion of plasmodium, whereas sporangia typical of the two ispecies respectively were produced from those portions of plasmodia farthest removed from the point of contact of the two plasmodia. Without entering into minute specific details, it will be sufficient to state that Physarum leucophacum has a dark-brown stem and a thin capillitium with few knots of lime, whereas Physarum leucopus has a white stem and stout capillitium with numerous large knots of lime. The hybrid has a white stem and a slender capillitium with few knots of lime. In the Kew herbarium there is a specimen collected at Highgate by Dr. Cooke, which agrees exactly with the hybrid described above, and which appears to have specially attracted the attention of Mr. Arthur Lister, who in going over the collection of Myxogastres, made a careful drawing of the specimen, adding, "Physarum leucophaeum with a pale stalk." I lave also produced a hybrid from two species of Trichia. Mr. Harold 
Wingate, of Philadelphia, sent along with other Myxogastres, a specimen with the following comment-

"No. 25. Is the teratological result of an amour between the plasmodium of Arcyria punicea and that of Arcyria cincrea. It gives a point as to the absolute autonomy of plasmodia."

In reply to further inquiry respecting the supposed hybrid, Mr. Wingate writes, "The Arcyria hybrid is not doubtful. Two patches of Arcyria, punicea and cinerea, grew on the same log, side by side; where the two came together the plasmodia fused and produced the result I sent." The specimen is extremely interesting, different individuals varying to a considerable extent in the relative resemblance to one or other of the parent forms. For the production of a hybrid, it is assumed that conjugation-or its physiological equivalentliad taken place between the cells of the two parent forms. The significance of the possibility of hybrid forms occurring in nature may eventually qualify to some extent present ideas as to "species."

Zopf $^{1}$ has recently investigated the Myxogastres, more especially from the biological side, but so far as I can ascertain, does not express himself definitely as to their animal or vegetable nature.

Mr. Saville Kent ${ }^{2}$ espoused De Bary's view as to the animal nature of the Myxogastres, and suggested their affinity with the sponges. The two principal reasons given as favouring their exclusion from the vegetable kingdom are-(1) first product of spore germination, bodies capable of spontaneous movement; (2) presence of crystals of lime in substance of cell-walls. The first objection proves nothing at all, and the second, if anything, how little Mr. Kent knew about plant morphology.

Dr. R. Hesse has recently announced ${ }^{3}$ that the members of

${ }^{1}$ Die Pilzthiere oder Schleimpilze. Schench's Handb. der Bot., vol. iii.

3 A Mamual of the Infusoria.

${ }^{3}$ Bot. Centrallb., xxxviii. (1889), pp. 518-20, 553-7. 
the Tuberaccae and the Elaphomycctae originate as masses of swarm-cells, which after passing through various phases, assume the well-known ascigerous form, and that these groups, if kept in the fungi at all, must be placed with the Mycetozoa. He further considers that the typical members of the Hymenoyastreae and the Lycoperdeaceae present similar characteristics in the earliest condition. If corroborated, the above statement will show how imperfect and superficial has been all previous work on these groups.

The following remarks by Mr. A. Lister are considered by the author as favouring the animal nature of the Myxogastres; but as usual, the evidence is afforded entirely by the vegetative phase, and consequently still much in touch with their aquatic progenitors, the Flagcllatae, whereas the individuality of the Myxogastres, as it appears to me, is to be found in the reproductive phase, and further, the individuality is obviously due in main to the change from an aquatic to an aerial habitat. In all probability the sexual method by conjugation was the one followed by the aquatic primitive forms, and if so, we find an agreement more or less pronounced with the ferns, where the prothallus, the sexual organ of reproduction, is structurally in touch with the aquatic forms from which this group is supposed to have evolved, whereas the truly aerial spore-producing form is the portion that gives most individuality to the ferns.

"At a meeting of the Linnean Society in April 1889, I described the mode of feeding which I had observed in the swarm-cells of Stemonitis fusca. I have since been able to watch the same process in the swarm-cells of several other species. Those of Pcrichaena corticalis afforded an interesting instance, because of the great activity of the bacilli which abounded in the preparation, and as showing the voracity of a few individual swarm-cells. One was noticed which already contained four vacuoles stuffed with bacilli, probably six to eight in each. It was observed to throw out several long pseudopodia from the posterior region, to which active bacilli became attached. In the course of twelve minutes four were 
seen, under a Beck's $\frac{7}{1} 0$ th immersion lens, to be drawn in and conveyed into freshly formed vacuoles.

"I have repeatedly seen bacteria taken by swarm-cells of Chondrioderma difforme in the manner above described, and it would appear that bacteria form their principal food. On one occasion I had a favourable opportunity for observing the digestion of bacilli on account of the quiescent state assumed by a swarm-cell, which remained with little active movement for an hour and a half. On the previous evening I had placed some spores of Chondrioderma difforme in water under a thin cover-slip; on the following morning swarm-cells were in great abundance in the pure water. I introduced a drop containing multitudes of bacilli from a glass in which a piece of Stereum hirsutum had been soaking for several days. In a short time a number of the swarm-cells were seen, attended by bacilli, some of which were attached to their pseudopodia, and some were already enclosed in vacuoles. The swarm-cell in question had taken an amoeboid form, occasionally producing and again withdrawing the cilium, while from time to time thin pseudopodia were extended from the opposite end, but more frequently the posterior region expanded into a somewhat funnel-shaped mouth. Into such au expansion a stout bacillus, about $2 \mu$ long, was seen to enter; in the course of a few seconds it was enclosed with a noticeable amount of water, by the folding over of the lips of the funnel, and conveyed into the body-substance; a few minutes after, another bacillus was taken in, much in the same manner, but no globule of water was introduced. Ten minutes later a large bacillus, $4 \mu \times 0.75 \mu$, was caught by a prolongation of one sille of the funnel, and in the course of half a minute a tube-like extension of protoplasmic substance invested the bacillus, and it was drawn in. It remained for a short time in direct contact with the granular matter of the body, but was soon surrounded by an oval vacuole. The swarm-cell continued inactive for nearly an hour, when it assumed an extended form, and shortly after swam away with rapid jogging movement. Constant observation was maintained during this hour, and the bacilli were seen gradually to dissolve 
in the vacuoles in which they lay, until at length all trace of them had disappeared together with their containing vacuoles, and only the contracting vacuole remained in the homogeneous granular substance of the swarm-cell.

"At the commencement of the observation this granular protoplasm was much more turbid than at the close, when it was remarkably hyaline; the swarm-cell appeared also to have increased in size, though it was difficult to determine by measurement in consequence of its changing form. No rejection of refuse matter took place while the observation lasted.

"In the same preparation I watched a swarm-cell creeping in a straight line with the strange snail-like movement, so difficult to understand. In its course it came to a small group of motionless bacilli lying against the glass; immediately it changed its linear form and spread itself out, covering four of the bacilli. In about two minutes it resumed its former shape and movement and crept away, carrying off two of the bacilli in vacuoles.

"These observations seem to confirm the opinion of De Bary, that the organisms under consideration should be classed among the animal rather than the vegetable kingdom, which led him in $\mathbf{1 8 5 8}$ to adopt the term Mycetozoa in place of that of Myxomycetes for the group. When a creeping swarm-cell is watched, with the projecting cilium placed immediately in advance of the nucleus, which never shifts its position, and when, as in the last-mentioned case, we note the manner in which the vibrating extremity of the cilium appeared to detect the presence of the bacilli before the swarm-cell spread itself over them; again, when we observe the creeping action suddenly change, and raising itself from the decumbent attitude, with a few lashing strokes of the cilium the swarm-cell releases its foot-hold and swims away; and when to these remarkable movernents is added the process of ingestion which has been described; we cannot but feel the force of the conclusion at which De Bary arrived, if indeed a distinct line of demarcation between the two kingdoms can be said to exist." 1

The brilliant and pure colours presented by the plasmodia of

1 Notes on Chondrioderma difforme and other Mycetosoa; Aun. Bot., Vol. IV. No. xiv. (May 1890), pp. 281-298, 1 pl. 
the Myxogastres are very remarkable; their significance is at present unknown.

The following list of colours observed is taken from $\mathrm{Mr}$. $\mathrm{A}$. Lister's paper, "Notes on Chondrioderma difforme and other Mycetozoa." 1

Species.

Amaurochaete atra

Arcyria cinerea ...

ferruginea

" incariata

mutans (buff variety) $\cdots$ untaus (red variety) ...

"̈ puricea ...

, utriculeris

Brefeldia maxima

Chondrioderma difforme

"Michelii

" spumarioides ...

Clathroptychium megulosum

Comatricha Friesiume

" typhina ... ...

Comnuia metallica

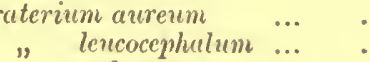

"vulgare...

Cribraria argillacea

" arerantiace

Diachaca lcucopoda

Dictydium cernum

Didyminm claves

(= D. Listeri, $\ddot{M}($ lss.)

"microcarpon

"squamilosum

Enteridium olivaceum ...

Fuligo varians ... ...

Hemiarcyia mbifom is

Lamproderma irilea (Clie.)

Lycogula epidendrum ...

Physurum tompressim ...

" levcophacut ...

Reticularia lycoperdon $\ldots$

Spumaria alba ... ...

Stemonitis fermuginea ...

mi" fusca ... ...

Tilmadoche mutabilis ...

Trichia affinis

, fullax $\quad \ldots \quad$...

Colour of Plasmodium.

yellowish white.

greyish white.

rose.

white.

white.

white.

wlite.

greyish white.

orange yellow.

pure white.

white to orange yellow.

opaque white.

... watery white.

... rose.

... watery wlite.

... watery white.

colourless.

lemon yellow.

yellow.

yellow.

... lead-eoloured in rising sporangia.

... sap green.

white.

... purple in rising sporangia.

... grrey.

... colourless.

... brownisl grey.

... watery white.

... rosé.

... yellow.

... purple in rising sporangia.

... colourless.

... rose.

... greyish whit?

... Watery white to greenish.

... opaque white.

white.

... white.

... lemon yellow.

white.

... yellow.

pure white.

... white and rose.

white. 
The plasmodium of most species inhabiting dead leaves is discoloured by foreign matter before the change to sporangia takes place.

The foregoing remarks may be summarized as follows-

1. The Myxogastres, as stated by De Bary, appear to have originated from a primitive group of aquatic organisms, the Flagellatae.

2. The sequence of differentiation which gives individuality to the group, is almost entirely confined to the reproductive phase, and follows in many important points, the lines of development observable in the Fungi.

3. The subordinate position occupied by the Fungi and the Myxogastres in the general evolution of the vegetable kingdom may be traced to the absence of chromatophores. The lichenforming fungi have succeeded in correcting this fundamental omission in an indirect manner.

4. There is no evidence in favour of the supposition that the Myxogastres are degenerated members of the vegetable kingdom, whereas the idea that fungi originated by differentiation from chlorophyll-bearing plant ancestors is generally admitted.

5. The Myxogastres with allied forms included by Zopf differ from all known members of the vegetable kingdom in having the component cells naked, or without a cell-wall, during the entire vegetative phase.

\section{Classification.}

In addition to the Myxogastres as defined in the present work, other smaller groups, as the Acrasieae of Van Tieghem; the Monadineae of Cienkowski, \&c., are supposed to possess certain important characters in common with the Myxogastres, and have been by some authors united into one group.

The following outlines of the various schemes of classification will indicate the views of affinity as proposed from time to time.

The term Mycetozoa as already explained, was first used by De Bary, ${ }^{1}$ and in his latest work on the subject this name is retained as follows :-

1 Die Mycetozucn, Zeitschrift f. wiss. Zoologie, Bd, x. 1859. 


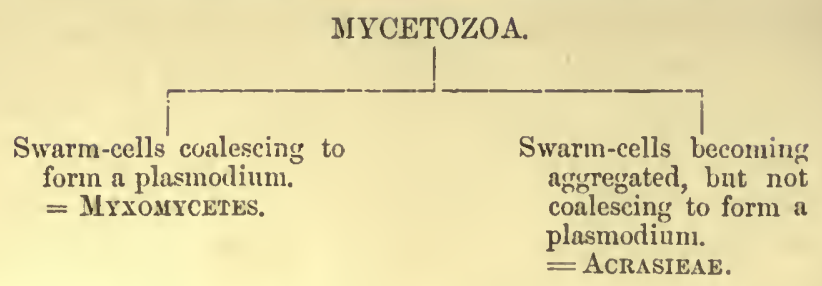

Cienkowski's Nucleariae and Vampyrellae along with such genera as Bursclla, Protomyxa, Myxastrum, Monas, Monadopsis, Pscudospora, Colpodella, and Plasmodiophora are considered by . De Bary as "doubtful Mycetozoa" for the following reasons. "I here exclude from the ranks of the true Mycetozoa a few forms or groups of forms, some of which have been occasionally mentioned in the preceding sections. Those forms, so far as they are known, have many points of resemblance with the Myjectozoa, but either our knowledge of them is imperfect, or else they depart so far in certain points from the typical Myxomycetes and Acrasieae, that it is better to leave their position in the system for the present undetermined." 1

Although De Bary clearly indicated that the existing classification of the Mycetozoa was very imperfect, being the outcome of pocket-lens observations on mature forms, and as above indicated, pointed out a scheme in accordance with the modern system of research, yet, lacking time, he never completed all the details necessary for a thorough revision of the group. This was done however by Dr. Rostafinski, a student of De Bary's, and as at least some of Rostafinski's important work on this subject was done by Rostafinski in De Bary's laboratory at Strassburg, we may presume that the general scheme was more or less inspired by De Bary.

Rostafinski confined his attention to the group Myxomycetes as defined by De Bary, and this group he calls Mycetozoa, thus using the same name in a narrower sense than De Bary, who included the Acrasicce that do not form a plasmorlium, and in bis Monograph ${ }^{2}$ recognized two primary divisions-ExosPonEAE,

1 Fungi Mycetozou and Baetcria, Engl. ed., 1) 446.

2 Mongrafia Sluzowec, Paris, 1875 (in Polish). 


\section{A Monograph of the Myxogastres.}

having the spores produced externally on slender sporophores, a feature met with only in the genus Ceratium; and ENDOSPOREAE, having the spores produced in sporangia. In the second "Appendix" to the Monograph, amongst other changes in the classification, the Exosporeat division is omitted altogether, and the Endosporous division alone retained. In Rostafinski's classification the two primary divisions are founded on the "colour of the spores as seen under the microscope by transmitted light; each primary division is further divided into two sections determined by the presence or absence of a capillitium as shown in the following arrangement-

\section{MYCETOZOA.}

\section{ENDOSPOREAE.}

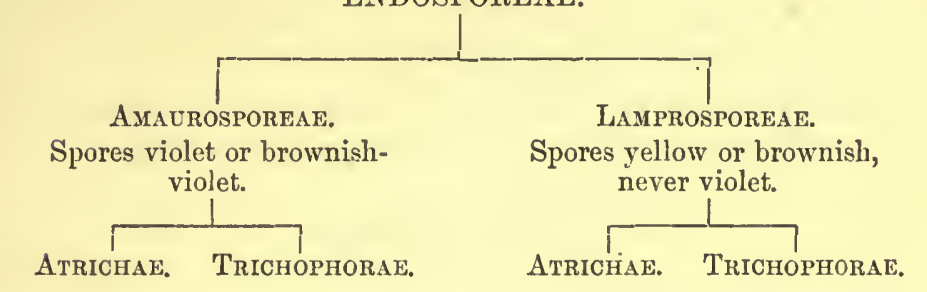

Von Tieghen uses the name Myxomycetes in a broader sense than De Bary's IFycetozoa, and arranges the groups as follows:-1

MYXOMYCETES.

\section{THALLUS.}

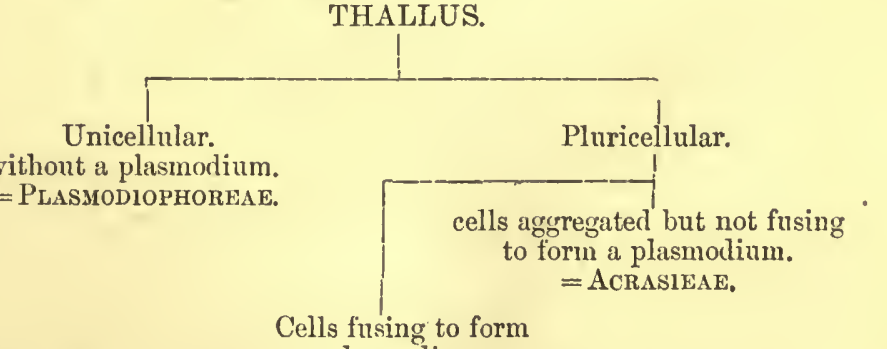

a plasmodium.

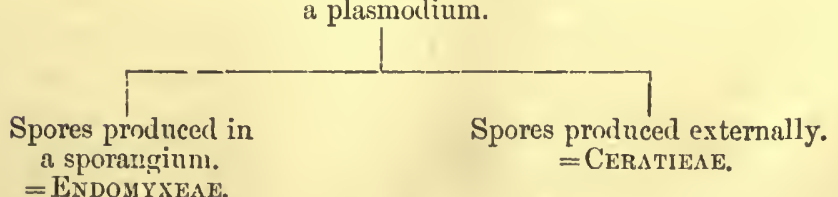

a sporanginn.

1 Traité de Botanique, p. 992 (1884). 
Zopf's Mycetozoa include many forms that do not come within De Bary's conception of the Mycetozoa as already defined. The following illustrates the primary divisions as adopted in his latest work. ${ }^{1}$

\section{A. Monadineak.}

Mostly aquatic, partly parasites; resting cysts are usually formed.

\section{Monadineac azoosporeae.}

Vampyrelleac; Burscllineae; Monocystaccae.

II. Monadincac zoosporeae.

Pseudosporeae; Gymnococcaccae; Plasmodiophoreac.

\section{B. EumycetozoA.}

Aerial. Never parasites; plasmodia always present, generally well developed; fructification generally well developed.

\section{Sorophoreat.}

Guttulincac: Dictyostcliaccae.

\section{ENDOSPOREAE.}

a. Peritricheae.

Clathroplychiuceae; Cribrariaceac.

ß. Endotricheac.

* Sicreoncmeac.

Culcariaccue; Amaurochataccae.

* Calonemeac.

Trichiaccue; Arcyriaccac; Reticulariaceac; Liccaccae ; Prorchacnaccae.

\section{ExosporeaE.}

In Raunkier's Myxomycetes Daniae ${ }^{2}$ the following classification is proposed-

- I Die Pilzthiere oder Schleimpil\%e (Schenk's Handbuch der Botanil, in Encylil. (ler Naturwissenschaften), 1884.

2 Botanisk Tiddskript, 17 Bind. (1888). 
A. Capillitium absent.

\section{Homodermeae.}

Liceaceae. (Tubulina, Lindbladia.)

II. Heterodermeae.

Clathroptychaceae. (Enteridium, Clathroptychium.)

Cribrariaceae. (Cribraria, Dictydium.)

B. Capillitium present.

III. Collonemeae.

Arcyriaceae. (Perichaena, Lachnobolus, Arcyria, Cornuvia, Lycogala.)

Trichiaceae. (Hemiarcyria, Trichia.)

IV. Stereonemeae.

Physaraceae. (Badhamia, Physarum, Tilmadoshe, Fuligo, Leocarpus, Craterizum.)

Didymiaceae. (Chondriodcrma, Lepidoderma, Didymium, Spumaria.)

Stemonitaceae. (Lamproderma, Enerthenema, Ancyrophorns, Comatricha, Stemonitis, Brefeldia, Reticularia.)

The Myxomycetes are divided by Schröter ${ }^{1}$ into three principal groups as follows-

A. Mature fructification consisting of a mass of free spores.

* Saprophytes; the amoeboid bodies unite in masses, but do not coalesce $=$ ACrasieaE.

* * Parasitic in the interior of living cells, forming in the known instances, a true plasmodium $=$ PнутоMYXINEAE.

B. Spores formed in the interior of sporangia, or on the outside of discoid or columnar fructifications = MYxoGASTRES.

At the close of the vegetable period, the passage of the motile plasmodium into the stationary reproductive condition is abrupt, and takes place as follows; the surface of the plasmodium becomes elevated into one or usually many protuberances, the original investment of the plasmodium is continuous over these

${ }^{1}$ Engler u. Prantls' Natürl. Pflanzenfam., 36 Leif., von Y. Schröter, 1889. 
protuberances into which the whole of the protoplasm passes, leaving behind the remainder of its pellicle attached to the substratum, and known as the hypothallus. When these protuberances, which may be sessile or stipitate, are symmetrical and individually distinet, they are called sporangia; when sporangia are irregular in form, usually veinlike and creeping, the term plasmodiocarp is used; finally, when the sporangia are densely aggregated, so that their individuality disappears to a greater or less extent, an acthlium is produced. The three conditions are connected by intermediate links. Aethalia are most frequently sessile on a broad base, as in Tubulina cylindrica and Entcridium olivaccum, but stipitate aethalia are not uncommon, especially in the Trichicceae, where the transition from typical sporangia to aethalioid forms in many species is very instructive.

As previously stated, the late Professor De Bary was the first to show, by his admirable researches on the morphology and physiology of the Myxogastres, that the systematic arrangement then in vogue was no longer tenable, owing to the fact that it was founded on analogies rather than affinities; and although at the present day it must be admitted that, within the group, affinities are far from being settled, yet, the appearance of Dr. Rostafinski's Monograph based on De Bary's researches, gave a fresh impetus to the study, ard showed in a masterly m:mner, that well-marked morphological features, far beyond the ken of pocket-lens revelation, could be utilized in connection with the systematic disposition of the members of the group. Among the essentials still lacking for an approximately correct classification are more especially-amount of variability, as also its direction in the various sections; the relative value of such structures as the columella, capillitium, sporangial, aethalioid and plasmodiocarp furirs; the presence or absence of lime, as also its amorphous and crystalline condition as presented in different sections; and finally, what is undoubtedly of primary importance, a complete knowledge of the lifehistory of at least the representative species of each section; and although complete life-histories inight not in all cases be 
possible, yet in so difficult a subject, the modus operandi alone would enable others to follow along the same lines. In the present state of knowledge, the markings usually present on the epispore appear to be constant within narrow limits, are often very characteristic, and of value as one factor in the discrimination of what we at present consider to be species, nevertheless I wish to express the strongest dissent to species founded on spore characters alone, or indeed on any one character. Rostafinski was the first to use spore characters in a specific sense. It is important to bear in mind, that the apparent nature of spore ornamentation depends entirely on the amount of magnifying power used; the complex epispore of Trichic affinis appears only as a confused series of minute irregular projections under a quarter-inch objective, consequently there is no absolute character in the spore unless a uniform magnifying power is agreed upon. The objective used in determining the nature of the epispore as described in the present work is a $\frac{1}{10}$ oil immersion, which gives a magnifying power of 1200 diameters. So far as the synonymy is concerned, I can only repeat in substance what I have written on a previous occasion in connection with the same subject. I have not included the synonymy further back than Rostafinski's Monograph, unless justified by the presence of type or authentic specimens. Rostafinski has given synonyms dating from the time of Micheli (1729), but on referring to the earlier descriptions, I realize my weakuess, in not being able to reconcile the wonderfully brief descriptions, and equally crude drawings, with modern species, which in many instances require a magnifying power of 1000 diameters for their determination, hence I wish to be clearly understood that the synonyms headed "Rostafinski's Synonyms," are copied from Rostafinski's Monograph without any attempt at corroboration. I feel certain that nearly one-third of Rostafinski's work would not have been sacrificed to synonyms unless they mean something more than I have been able to discover, hence I have not felt justified in ignoring them altogether. 


\section{MYXOGASTRES (FRIES).}

Myxogastres, Fries, Syst. Myc., iii. p. 67 (1829); Schroeter, $K r . F l$. Schles., Vol. iii. p. 98.

Myxomycetes, Wallr., Fl. Crupt., ii. p. 333 (1833); Cooke, Brit. Myx., p. 1; Raunk, Myx. Dau., p. 20; Sacc., Syll., Vol. vii. pt. i. p. 323.

MycetozoA, De Bary (Dic Mycetozoen, 1864); Rost. (Mon. Sluzowce) (in part).

Pilztulere, Zopf, in Schenk's Handb. der Bot., Vol. iii. (18s4) (in part).

Consisting during the cntive vegetative period of an accumulation of naked cells forming a plasmodium possessed of the power of movement, and invested with an imperfectly differentiated, yielding membrane. This plasmodium at length becomes transformed into sporangia containing numerous spores which form a powdery mass at maturity. First product of spores on germination either ciliated zoosporcs or amoeboid cells, which aftcr repcated bipartition and conjugation, combine to form a plasmodium.

The species are usually aerial, the plasmodium stage bẹing pussed in rotten wood or amongst decaying vegetable matter, and coming to the surface only to form the sporangia; nevertheless several species have been observed to pass the whole of their existence under water. The sequence from the aquatic to the aerial condition may frequently be seen in the same batch when developing on logs that are partly submerged.

The most pronounced feature in the evolution of the Myxogastres is in connection with spore dissemination, and the following arrangement is based on the relative development of the capillitium, which is seen in its most perfect form in the genera Trichia and Arcyria. In the Gastromycetcs I have shown elsewhere ${ }^{1}$ that the sequence of evolution all tends towards securing in the most efficient manner, the dissemination of the spores; commencing with the subterranean genera Rhizopogon and

${ }^{1}$ A Monogruph of the British Gastromycetes. Ann Bot., Vol. ir. pp. $1-103$ ( 4 plates). 
Hymenogaster, where the spores are liberated only by the decay of the plant without any apparent morphological provision for their dispersion, we trace, as the above ground genera appear, the gradual evolution of the capillitium through such genera as Diploderma and Scleroderma, until in Lycoperdon we find the highly specialized byphae forming the capillitium effecting at maturity the rupture of the peridium, and consequent dispersion of the spores. This phase is the most perfect, so long as dispersion is effected by mechanical methods, but in the Phalloileae we find the mechanical method superseded by a totally different idea; brilliant colours, usually combined with a strong odour, and the presence of a sweet substance, bid for the visits of insects, which in return disperse the spores. In the Myxogastres the mechanical method of spore dispersion is the most perfect condition attained, as illustrated by the rough, elastic capillitium of many species of Arcyria. The above allusion must not be interpreted as implying relationship between the Gastromycetes and the Myxogastres; in fact I see in this point of agreement no more proof of affinity than exists between the Phalloideae and those flowering plants that make use of the same announcements to insects, in the form of colour, scent, and honey in connection with pollination. I consider the Myxogastres as illustrating one of the earliest known attempts at differentiation in the direction that has eventually resulted in the mass of organisms constituting the vegetable kingdom, but having originated from the Flagellatae, a group more in touch with the animal side of life, the work of developing individuality has been slow, as illustrated by the tardy appearance of cellulose cell-walls, which, as would be expected, is most complete in the newly evolved reproductive phase, itself to a great extent the outcome of a gradual change of environment from aquatic to aerial-but the radical mistake, after having adopted the plant line of development, consisted in the non-development of chromatophores, and retention of the animal mode of nutrition, which in the plant world means parasite or saprophyte. The fungi, a later gromp, differentiated from ancestors that had already evolved the leading plant characteristics, including cell- 
walls, chlorophyll, starch, hence in this respect are more typical plants than the Myxogastres; but in the fungi the check to progress was due to the degeneration of chromatophores, already evolved by their ancestors, whereas in the Myxogastres the check was due to their inability to differentiate these essentials.

\section{MYXOGASTRES.}

Order. Peritricheae.

Wall of sporangium not incrusted with lime; capillitium absent or formed from wall of sporangium.

Sub-Order. Tulnulinae. Wall of sporangium not perforated.

Sub-Order. Cribrariae. Wall of sporangium perforated.

Order. Columelliferae.

Wall of sporangium without lime; capillitium originating from a central, usually elongated columella.

Sub-Order. Stemonitae. Capillitium springing from every part of an clongated columella.

Sub-Order. Lamprodermae. Capillitium springing from the apical portion of a short or elongated columella.

Order. Lithodermeae.

Wall of sporangium with an external deposit of lime; capillitium present.

Sub-Order. Didyneac. Threads of capillitium without lime.

Sub-Order. Physarae. Capillitium containing lime.

Order. Calotricheae.

Wall of sporangium without an external deposit of lime; capillitium present, not springing from a columella.

Sub-Order. Trichcac. Threads of capillitium free, simple or branched, not anastomosing to form a network.

Sub-Order. Areyriae. Threads of capillitium either attached by one end with the free tips more or less branched, or combined to form an irregular network.

The following diagrammatic arrangement is an attempt to illustrate my ideas of relationship between the several orders.

The bracketed generic names represent the points of contact 
between respective orders, and the names in italics to the right and left indicate those genera that illustrate the maximum of development characteristic of the orders to which they are respectively attached.

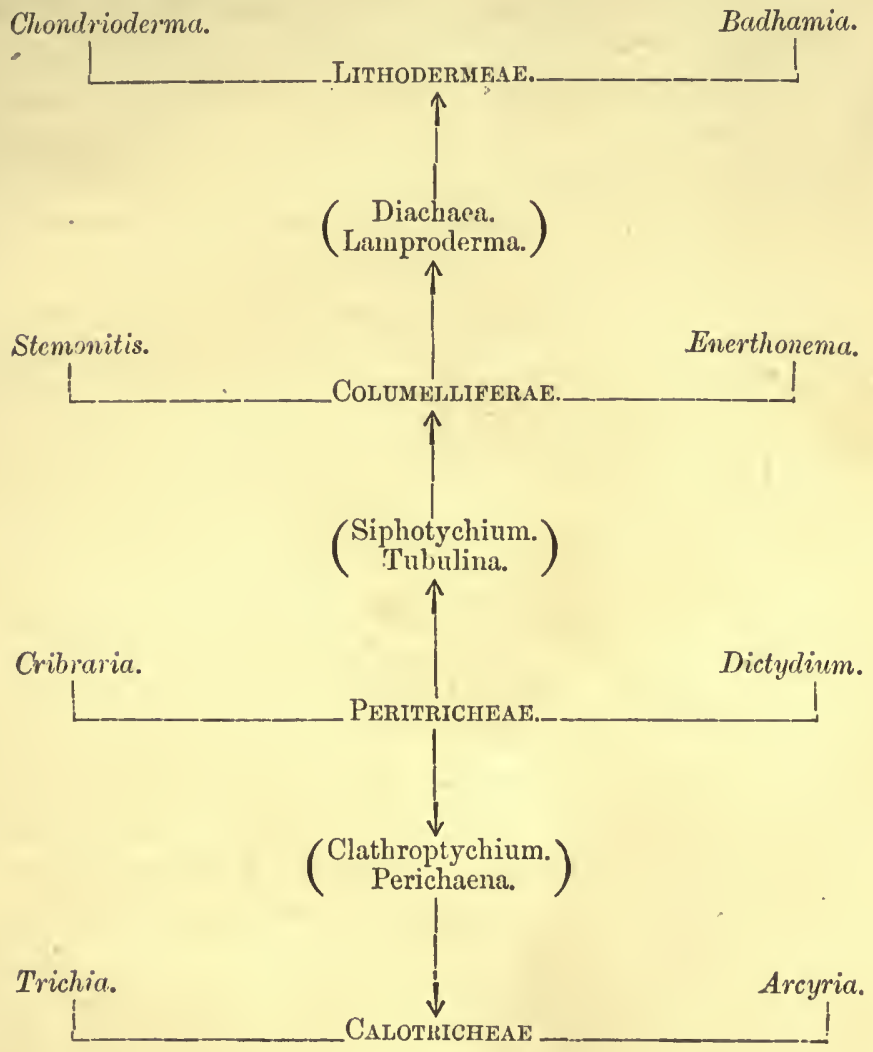

In each order we find the special characteristic idea evolving through a sequence of genera, the terminal one not connecting with any higher order, hence the special feature terminates abruptly within the order where it originated, and it is invariably in some comparatively undifferentiated genus near the initial point of each order that we meet with the suggestion of a new line of evolution, which at its maximum of development, constitutes the characteristic feature of the order immediately 
in advance of the one from which it emanated in an incipient condition; hence in the Peritricheac, starting with the genus Tubulina, the marked characteristic of the order-a perforated sporangial wall-evolves gradually through Protodermium to Dictydium, where it attains its highest phase of development, and then terminates abruptly; whereas in E'nteridium, a coinparatively primitive genus, we get a transition from slightly perfurated walls to a complete breaking up of their substance into an irregular network, which leads by degrees to the central columella and capillitium characteristic of the Columellifcrae.

\section{PERITRICHEAE.}

The present order includes the most primitive types met with in the Myxogastres, illustrated by such genera as Tutulina, of which the plasmodiocarp condition, representing a plasmodium covered by a common cortex, is the lowest phase; when the substance of the plasmodiocarp becomes broken up into smaller portions by special walls, an aethalium is produced, and finally, by the gradual isolation of the components of an aethalium we get the sporangium or most highly specialized form of reproductive organ, characteristic of the higher sections; but we everywhere meet with plasmodiocarp and aethalioid conditions, proving the comparative instability of the acquired sporangial phase. In the present order we learn that the primitive idea in connection with spore dissemination was that of modifying, or rather differentiating, the sporangial wall. The original function of the wall was protective, as illustrated in the genus Tululina, where we find this to be its only function, there being no provision for spore diffusion other than that brought about by the decay of the wall, which does not take place readily, and the subsequent dispersion of the spores by wind or rain. Passing on to such genera as Enteridium and Clathroptyelivum, we find the sporangial wall yet performing, as it continues to do in every section, the function of protection, and remaining intact until the spores are fully differentiated; but in these genera certain portions of the wall have become specially 
thickened, and at the period of maturity, the thickened portions are persistent, while the remaining portions of the wall disappear, and as this thickening is usually of. a determinate nature, and utilized as a generic factor, we meet witl the small, fairly regular openings in the lateral walls presented by one of the members of the genus Enteridium, or the still larger openings of Clathroptychium; but, although the modification is a step in the right direction, owing to the fact that the species constituting the two genera named retain the aethalioid condition, the new idea is of but little practical value; and it is only when we come to Cribraria, the components of which for the most part have reached the condition of forming small detached plasmodia, each only sufficiently large to form a single sporangium, that we realize the value of the perforated sporangial wall, which, other things being equal, is better than the sealed up, entire sporangium, inasmuch as at the moment the spores are mature, there is a chance of being removed from the sporangium by wind or rain; but in Cribraria the stem, although usually elongated, is rigid, and it is in the genus Dictydium that arrangements for spore diffusion from a perforated sporangium is most perfect. In this genus the thickened, permanent portions of the sporangium are arranged in the form of ribs radiating from the base and converging again the apex, being connected by very thin, transverse bars, forming a hollow sphere of lattice-work; this globe is pendulous from a long stem curved at the apex, and while the stem is rigid during the young condition, towards maturity the upper portion above the curve becomes shrivelled and flaccid, and the sporangium hangs in a condition ready to be dangled by the wind or the movements of minute insects; how effectual this method of spore diffusion is in its way is proved by the specimens being generally found destitute of spores. In Enteridium, as already mentioned, we find in one species the wall symmetrically perforated, whereas another species has the walls of the component sporangia forming the aethalium so irregularly perforated, and forming a variable network, that at first sight the aethalioid nature of the mass is masked, and this species may be considered as forming, 
a connecting link with another order, the Columelliferae, where the capillitium originates in a totally different manner. The following arrangement illustrates the evolution of the genera included in the Peritvicheae, and the points of affinity with other orders-

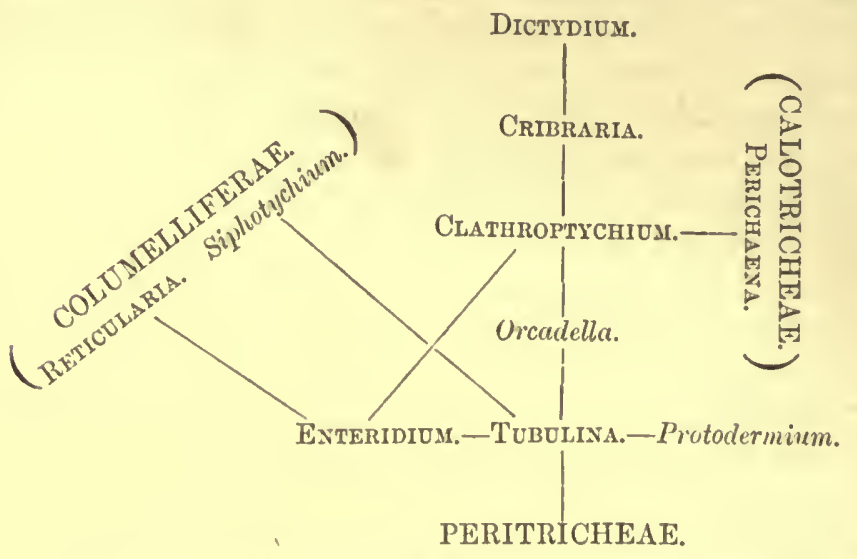

(British genera are printed in smatr capitals, exotic genera in ilalics.)

\section{ANALYSIS OF THE GENERA.}

PERITRICHEAE.

Sub-sect. Tubulinae.

Tubulina. Sporangia crowded to form an aethalium.

Protodermizum. Sporangia scattered.

Sub-sect. Crimrariae.

Orcadella. Sporangia perforated at the apex.

Evteridium. Sporangia with sinall lateral perforations, or broken up into an irregular network.

Clathioptychium. Sporangia with large symmetrical openings in side walls, apices of sporangia permanent.

Cribraria. Permanent portions of upper part, or whole of sporangium forming an irregular network.

Dictydium. Permanent ribs of sporangium radiating from the calyculus and converging towards the apex, joined by thinner transverse bars. 


\section{Sub-sect. Tubulinae.}

Tubulina, , Pers. (emended).

Sporangia scattered and regular, or irregular and forming a plasmodiocarp, or compacted together to form a naked or corticated aethalinm; walls very thin, single, often iridescent, not perforated; columella and capillitium absent.

Tubulina, Persoon, Syn. Fung., p. 197 ; Rost., Mon., p. 219 ; Cooke, Myx. Brit., p. 54; Sacc., Syll., Vol. vii. p. 406 ; Schroeter, p. 102; Zopf, p. 172 f. Licca, Schrader, Nov. Pl. gen., p. 17 ; Rost., Mon., p. 218; Schroeter, p. 102 ; Zopf, p. 171 ; Sacc., Syll., Vol. vii. p. 404; Cooke, Brit. Myx., p. 54. Lindbladia, Fries, Summ. Veg. Scand., p. 449; Rost., Mon., p. 223 ; Cooke, Myx. Brit., p. 55 ; Sacc., Syll., Vol. vii. p. 408; Zopf, 172.

A careful examination of ample material has convinced me that the three genera given above constitute but one natural genus, and Tubulina, having priority, has been adopted. The structure and origin of an aethalium being unknown to the old mycologists, explains the origin of these genera; but it is remarkable that Rostafinski, who so lucidly explains the origin and value of aethalia, did not notice the sequence so clearly stated in his own diagnoses of the three genera, which he retains. In all three the sporangial walls agree in being membranaceous and not.perforated; Licea has the sporangia regular, as in $L$. minima, Fr., or irregular and forming a plasmodiocarp, as in L. flexuosa, Pers. ; in Tubulina the sporangia are cylindrical or prismatic from mutual pressure, and combined to form a naked aethalium; while in Lindbladia, the sporangia also form a naked aethalium, but although prismatic, as in Tubulina, are not quite so much elongated; finally, the species described as Licea spumarioides, Cke. and Mass., belongs to one of the trio, but differs from all in having the sporangia flexuous, and in the aethalium being covered with a common cortex. If Rostafinski's view as to the autonomy of the three genera in question is correct, it follows that the acthalioid condition of such species as Hemiarcyria rubiformis, Rost., must not only be separated from the form with simple, normal sporangia, 
but must constitute a new genus, which exactly illustrates the difference between Licea and Lindbladia or Tubulina respectively; whereas the only distinction given by Rostafinski between Tubulina and Lindbladia amounts to saying that in the former the sporangia are elongated; in the latter, shorter.

A well-defined hypothallus is often present, and in some species, as T. stipitata, B. and C., forms an elongated, stem-like structure which possibly consists of sterile, modified sporangia.

Dr. Geo. A. Rex has kindly furnished me with a sequence of specimens, all belonging to Tubulinacylindrica as defined in the present work, which to my mind show clearly the transition from Tubulina to Siphoptychium, and thus furnishing a connecting link between the Pcritricheae and the Columelliferae.

Distrit. Europe; North America; India; Ceylon; Australia; Bonin Island: species, 11.

A. Sporangia, regular or plasmodiocarp.

Tubulina minima, Mass.

Sporangia scattered, sessile on a broad base, hemispherical or variously elongated, little depressed; wall thin, smooth; from clear to obscure brown; torn above into several persistent, irregular teeth; mass of spores umber, spores globose, minutely warted, 10-12 $\mu$ diameter.

Licea minima, Fr., Syst. Myc., iii. p. 199 ; Karst., Myc. Fenn., iv. p. 125 ; Sacc., Syll., 1385.

Licea variabilis, Schral., Nov. pl. gen., p. 15, t. vi., ff. 5, 6 .

Exsicc.-Karst., Fung. Fenn., 798.

(Specimen from Fries in Herb. Berk.)

Britain (Bulmer, Yorks).

On pine wood and sawdust. Germany; Sweden; Finland.

An obscure species, which, from its scattered habit, is easily overlooked; when circular from $5-1 \mathrm{~mm}$. across; frequently $2-3 \mathrm{~mm}$. when elongated. The colour varies from almost chestnut to blackish brown; ruptured above in an irregularly stellate manner.

The inner surface of wall of sporangium has numerous coloured cells or masses arranged in groups. 
Rostafinski's gratuitous suggestion that the present species is a Phelonitis is altogether wrong.

Tubulina flexuosa, Mass.

Sporangia scattered, sessile on a broad base, circular or variously elongated and flexuous, wall thin, single, shining; deep olive or tinged with brown; mass of spores olive; spores globose, pale olive-brown, minutely warted, the warts showing a tendency to form very short ridges, $12-15 \mu$ diameter.

Licca flexuosa, Pers., Syn. fung., p. 197, t. 1, f. 5, 6 ; Rost., Mon., p. 218 ; Schroet., p. 102 ; Sacc., 1382.

(Specimen named by Rostafinski in Herb. Berk.)

On decaying wood, especially pine. Britain (Aboyne, N. B.); Finland; Sweden; Germany.

From. 1-1.5 mm. when circular, often $2-3 \mathrm{~mm}$. when elongated. The wall of the sporangium is furnished inside with a layer of fine granules of organic matter.

(Rostafinski's Synonyms.)

Licea flexuosa, Pers., Syn. p. 197, t. 1, f. 5, 6 (1801).

Tutulina flexuosa, Poir., Enc., l.c. viii. no. 8 (1808).

L. serpula, Fr., Sym. Gast., p. 12 (1817).

L. spadicea, Fr., cfr., l.c. iii. p. 197 (1829).

Lycogala contortinu, Lk., Herb. non Ditm.

Aethalium minimum, Wallr., in litt.

Aethalium microscopicum, Wallr., Herb.

Licea alutacea, Wallr., Fl. Ger. cr. n. 2106 (1833).

\section{Tubulina spermoides, Mass.}

Sporangia cylindrical, shorter than broad, crowded, rarely scattered towards the circumference of the clusters, apex slightly rounded, wall very thin, dull, breaking up into whitish fragments, seated on a well-developed, thin hypothallus; mass of spores olive; spores globose, $6,7 \mu$ diameter, equally covered all over with minute warts.

Licea spermoides, B. and C., Grev. v. 2, p. 68.

Cribraria argillacea, Sacc., Syll., 7, n. 1415 (in part).

(Type in Herb. Berk. n. 10854.)

On wood, leaves, \&c. Alabama. Sporangia in a single stratum, 
often forming patches $6-9 \mathrm{~cm}$. long and broad; the hypothallus although thin, is tough, and can be peeled off the matrix. Sporangia about $5 \mathrm{~mm}$. diameter and not quite so high; before dehiscence yellowish olive and resembling a crowded Pcrichacna.

Tubulina spéciosa, Speg.

Sporangia densely gregarious, fasiculate, fascicles subcircular, $1-2 \mathrm{~cm}$. long and broad, 1-1 mm. high, seated on a slightly convex hypothallus; sporangia cylindrical, apices rounded, dehiscing irregularly, at first flesh-colonr then cinnabar, shining; spores warted, rusty-ochre; depressed, dry concavo-convex, with a thickish margin.

Spegazzini, Nov. Add. ad Myc.Ven. n.123; Sace., Syll., 7, n. 1393.

On rotten wood of Pinus silvestris. N. Italy.

I have had no opportunity of examining the present species, the spores of which are described as concavo-convex when dry, but in all probability become spherical when moist.

\section{Tubulina stipitata, Rost.}

Hypothallus stem-like, often sulcate, spongy within; sporangia crowded in a sub-globose head, cylindrical, apices rouniled; walls very thin, evanescent; mass of spores brownishumber; spores globose, $4-5 \mu$ diameter, about three-fourths of the surface with a regular small network, the remainder with much larger meshes. Rost., Mon., p. 223, f. 2; Cooke, Myx. Brit., f. 2 ; Sace., Syll., 7, n. 1392.

Licce stipitata, B. and C., Grev. v. 2, p. 68.

(Type in Herb. Berk. n. 10851.)

Exsicc. Fung. Cub. Wrightiani, šs 1.

On dead wood, bark, \&e. Stem 2-4 mm. thick and high, umber, porous within; sporangia $1.5-2 \mathrm{~min}$. long. The spores are globose when thoroughly soaked.

Dr. G. A. Rex of Philadelphia has recently sent specimens of the present species having the hypothallus very much reduced, and also informs me that sessile forms are not uncommon, hence the specific distinction between $T$. cylindrica and the present species turns mostly on spore differences.

Ciuba; Java; Bonin Islands; United States. 


\section{Tubulina guaranitica, Roumeg.}

Gregarious; sporangia globose, sometimes slightly attenuated below on passing into the stem; wall single, thin; dingy ochraceous with a tinge of olive, sometimes greyish below, about $1 \mathrm{~mm}$. diameter; stem rather thick, slightly incrassated downwards, and passing into a hypothallus, 15-2 mm. long, ochraceous-brown; mass of spores umber; spores globose, smooth, $7-8 \mu$ diameter.

Tubulina guaranitica, Roumeguère, Fung. Sel. exsicc., no. 5196. Licea? guaranitica, Speg., Fung. guaran., Pug. I, no. 322.

On decayed bark. Guarapi; Argentine Republic.

With the general appearance of a small specimen of Tubulina stipitata, differing in having only a single sporangium, or aethalium surrounded by a thin, friable cortex. The dimorphic capillitium described by Spegazzini as consisting of septate threads is clearly nothing more than the mycelium of some minute fungus spreading in the mass of spores. The tail-like appendages to the spores mentioned by the author are to be explained in the same way. The above description is drawn up from the specimens in Roumeguère's exsicc. These specimens were supplied by Balansa, and may therefore be considered as authentic, inasmuch as Spegazzini's Fungi guaranitica is an account of the Fungi collected by Balansa.

\section{B. Acthalium naked.}

Tubulina cylindrica, Rost. (f. 1-6).

Sporangia usually crowded and forming a naked cake-like brown aethalium, rarely scattered, seated on a well-developed flat or slightly convex hypothallus, cylindrical or subangular from mutual pressure, more or less elongated, apex rounded; wall single, thin, often iridescent; mass of spores brownishumber; spores globose, about three-fourths of the surface with a regular, fine-meshed network, the remainder with scattered ridges and warts, 7-9 $\mu$ diameter. Rost., Mon., p. 220; Cke., Myx. Brit,, p. 54 ; Sacc., Syll., 1391; Schroeter, p. 102. 
Tubulina nitilissima, Berk., Journ. Linn. Soc., v. 18, p. 387 (from examination of type); Licea rubiformis, B. and Curt. (from exam. of type).

Licea microsperma, B. and C. (from exam. of type).

Exsicc.-Syd., Myc. March., 1498; Cke., Brit. Fung., ed. ii., 528 ; Karst., Myc. Fenn., 697 ; Fekl., F. Rhen., 1470; Roum., Fung. Gall., 3066; Ellis and Everh., N. A. Fung., ser. II. 2096.

On wood. Forming compact cakes varying from half an inch to a foot or more in diameter, varying from umber-brown to chestnut, the surface granular with the convex apices of the sporangia. When immature and pulpy, of a beautiful strawberry colour. Hypothallus spongy, resembling when thick the sterile base of a Lycoperdon. Dr. Rex considers that two distinct species are confounded under the above name.

Britain (Apethorpe, Powerscourt, Brandon, Scarboro', Carlisle, Glamis, N. B.); Germany; France; Sweden; Finland; Hungary; Belgium; United States; India; Ceylon; Australia.

(Rostafinski's Syıonyms.)

T'ubulifera cercutum, Fl. Dan., t. 659, f. 2 (1777).

T'ubulifera arachnoidca, Jacq., Misc., t. 15 (1778).

Mucor tubulosus, Retz.

Stemonitis ferruginea, Batsch, f. 175 (1786).

Sphaerocarpus cylindricus, Bull., t. 470, f. 3 (1791).

Sphaerocurpus fragiformis, Bull., t. 384? (1791).

I'ubifera fcrouginosa, Gmel., Syst. 1472 (1791).

Tubifera cylindrica, Gmel., Syst. 1472 (1791).

Tubifera fragiformis, Gmel., Syst. 1472 (1791).

I'richia fragiformis, With., Arr., iii. 480 (1792).

Tubulifera coccinea, Trent., p. 243 (1797).

Iicca tubulina, Schrad., N. G., 16 (1797).

Licea clavata, Schrad., N. G., 18 (1797).

I'ubulina fragiformis, Pers., Disp., p. 11 (1797) ; Pers., Syn., t. 4, f. 3,4 .

Tuhulina fallax, Pers., Obs., ii. 28 (1799).

Tubulina fragiformis, a. papillata, $\beta$. clavata, $\gamma_{0}$ conica, 8. cuccinea, є. opcreulata: Pers., Obs., ii. 29. 
Reticularia multicapsula, Sow., t. 179 (1799).

Tubulina cylindrica, D. C., Fl. F., 674 (1805).

Tubulina fragifera, Poir., Ency., viii. No. 3 (1808).

Licea fragiformis, Nees, f. 102 (1816); Eng. Fl., v. p. 321;

Cooke, Hdbk., 1194; Fung. Brit., ii. 528.

Dermodium fallax, Nees, f. 103 (1816).

Licca cylindrica, Fr., S. Myc., iii. 195 (1829); Eng. Fl., v. 391 ;

Cooke, Hdbk., No. 1193.

Licea iricolor, Zoll., in Flòra (1847), p. 300.

Tubulina conglobata, Preuss., Linnaea, 140 (1851).

Tubulina effusa, Mass.

Acthalium naked, sporangia seated on a firm, common hypothallus, irregular from mutual pressure, in a single stratum or superposed, walls very thin, lustrous, grown together; free apices of sporangia slightly convex, giving the surface of the aethalium a granular appearance; mass of spores ochraccous-umber; spores globose, yellowish-brown, very indistinctly vervuculose, $6-8 \mu$ diameter.

Lindbladia effusa, Rost., Mon., p. 223; Schroet., p. 103 ; Cooke, Myx. Brit., p. 55; Sacc., Syll., no. 1395.

On the ground and on wood. Britain (Leicester, Epping, Scarboro', Aboyne, Forres, Linlithgow); Germany; Sweden; France; Bohemia.

Often forming compact, flattened cakes extending for three or four inches, sometimes much smaller; superficially closely resembling Tubulina cylindrica, but the mass of spores with a yellower tinge, and the present species also differs in the shorter sporangia, which are not so uniform in their arrangement as in T. cylindrica.

(Rostafinski's Synonyms.)

Licea effusa, Ehr., Sylv., p. 26, f. i. (1818). Actralium melaenum, Chev. Byss., iii. (1837). Lindbladia tubulina, Fr., S. V. S., 449 (1849). Aethalium atrum, Preuss., Linnaea, 141 (1851). 
Reticularia maxima, Corda, Ic. vi. 35 (1852).

Reticularia granulosa, CErstd. MSS.

C. Aethalium covered with a common cortex.

Tubulina spumarioidea, Cke. and Mass.

Aethalium large, irregular, cortex membranaceous, bright grcy, with anastomosing veins inside; walls of sporangia almost colourless, very thin and soon disappearing; mass of spores orange with a tinge of olive; spores globose, with rather large, oltuse varts, $16-18 \mu$ diameter.

Licea spumarioidea, Cke. and Mass., Grev., vol. xvi. p. 74 (1888).

Running over twigs and on the ground. Near Melbourne, Australia.

Aethalia subglobose cr irregular, varying from $\frac{z}{4}$ to 1 inch across, creeping up grass and twigs like Spumaria alla; common cortex bright grey, thin, subpersistent, with numerous anastomosing vein-like thickenings in the inside of the wall. Sporangia densely crowded, flexuous, wall thin, at first imperforate, soon disappearing.

Imperfectly linonon species.

Tubulina brunnea (Preuss.).

Closely gregarious; sporangia ochraceous-brown, rotund, subdepressed, wall papyraceous, irregularly torn, upper portion disappearing in a subcircumscissile manner; spores globose, minute, ochraceous, threads none.

Licea brunnea, Preuss., Hoyersw., n. 275; Schroet., p. 102 ; Sacc., Syll., 1387.

On semi-putrid trunks of pines. Germany; Silesia.

Tubulina Lindheimeri, Mass.

Broadly effused, externally blackish, mass of spores ferruginous-orange; spores globose, smooth, $6-7 \mu$ diameter.

Liica Lindhcimeri, Berk., Grev. v. 2, p. 65; Sacc., Syll., v. 7, n. 1388 . 
(Type in Herb. Berk. n. 10848.)

On dead bark. Texas.

The type specimen is so thoroughly crushed that it is impossible to say whether the plant is a Licea or a Tubulina, but in all probability the latter, as there appear to be indications of the bases of crowded sporangia.

Tubulina caespitosa, Mass.

Peridia aggregated in tufts or clusters, crowded, sessile, smooth, brown or blackish-brown; spores dingy ochre, smooth, globose, .00025 in. in diameter $(=5.5 \mu)$.

Physarum caespitosum, Peck, 26th Report, State Mus. N. York, p. 75 .

Rotten wood. Greenbush; U. States.

Protodermium, Rost.

Sporangia simple, solitary, regular in form; mass of spores blackish violet; capillitium entirely absent.

Protoderma, Rost., Mon., p. 90 ; Schroeter, p. 103; Cooke, Myx. Brit., p. 10.

Protodermium, Sacc., Syll., Vol. vii., pt. I., p. 325.

Rostafinski's name Protoderma was altered by Berlese in Saccardo's Sylloge to Protodermium, as the former had been already used for a genus of algae.

The present genus is identical with Tubulina except in the colour of the spores, a character which I look upon with doubt. Colour as presented by spores is undoubtedly of some significance, but being altogether in ignorance as to its relative physiological value, I cannot accept colour in Rostafinski's sense as being of such supreme importance as to constitute the basis for the primary divisions of the Myxogastres, even if the divisions indicated had really existed in nature, which however is far from being the case.

Distrit. Europe; United States: species 1.

Protodermium pusillum, Rost.

Sporangia gregarious, distinct, hemispherico-subdepressed, about $1 \mathrm{~mm}$. broad, chestnut-brown, shining; mass of spores 
black; spores globose, $16-18 \mu$ diameter; epispore blackish - violet, smooth.

Protoderma pusilla, Rost., Mon., p. 90.

Protoderniium pusillum, Sacc., Syll., Vol. vii., pt. I, n. 1139.

On rotten wood. Germany; Russia; United States.

\section{(Rostafinski's Synonyms.)}

Licca pusilla, Schrad., Nov. Gen., p. 19, t. vi., f. 4 (1797).

Physarum licea, Fr., S. M., iii., p. 143 (1829).

\section{Sub-sect. ' Cribrariae.}

Enteridium, Rost. (emended).

Aethalium covered with a general, irregularly perforated, membranaceous cortex; walls of component sporangia with symmetrical perforations, or irregularly broken up to form a capillitium-like structure.

Rost., Mon., p. 226; Cooke, Myx. Brit., p. 56; Schroeter, p. 103; Sacc., Syll., Vol. vii., pt. I., p. 409.

Very closely allied to the Clathroptychizm, which differs chicfly in the more complete absorption of the walls of the sporangia.

In $E$. olivaceum, which most nearly approaches Clathroptychivom in structure, the side walls of the sporangia are not so completely absorbed as in the last-named genus, hence the thickened angles formed by the walls of contiguous cells have broader and more irregular wings.

Distrib. Europe; United States; W. Australia: species 3.

\section{A. Spores Reticulated.}

Enteridium olivaceum, Rost. (f. 14-18).

Aethalium very variable in form, flattened or pulvinate, olive; general cortex papery, pellucid; walls of the crowded sporangia pellucid, yellowish-brown, perforated; mass of spores olive; spores in clusters of from 5-20, single sporcs truncate, the free portion convex and warted, remaining portion smooth, 11-15 $\mu$ diameter. 
Rost., Mon., p. 227, fig. 5 ; Cooke, Myx. Brit., p. 56, fig. 5 ; Schroeter, p. 103 ; Sacc., Syll., n. 1399.

Reticularia applanata, B. and Br., Ann. Nat. Hist. (1886), t. ii., f. 3.

\section{(Specimen in Herb. Berk., named by Rostafinski.)}

On wood. Britain (Kew, Scarborough, Appin, N. B.); Germany; Denmark; France; United States; W. Australia.

Irregularly effused for 1-2 inches, or sometimes in the cracks of wood and then elongated; colour dark greenish olive, the minute sporangia showing through the thin general cortex, and giving the surface a slightly papillose appearance. The side walls of the sporangia are more or less regularly perforated, the angles where adjacent sporangia meet being permanent and winged with the side portions of the walls that are not absorbed.

\section{(Rostafinski's Synonyms.)}

Lycoperdon undulinum, Schum. Saell., 1404 (1803).

Enteridium olivaceum, Ehr., f. 1, 5 A.E. (1818).

Reticularia versicolor, Fr., Obs., ii., 147 (1818).

- Licogala olivacea, Link, $\mathrm{Hb}$.

Reticularia olivacea, Fr., Syst. Myc., iii., 89 (1829).

Reticularia ungulina, Fr., in Fl. Dan., t. 1977, f. 2 (1823).

Enteridium atrum, Preuss., Linnaea, 142 (1851).

Reticularia applanata, B. and Br., Ann. Nat. Hist. (1866),

t. ii., f. 3 ; Cke. Hdbk., No. 1098.

Licea olivacea, Fckl. Symb., 338 (1869).

Licea glomulifera, De Bary and Rost., in Alex. (1872).

Licaethalium olivaceum, Rost. Vers.; p. 4 (1873).

Lindbladia versicolor, Rost., in Fckl., 68 (1873).

Enteridium Rostrupii, Raunk.

Aethalia irregular, lengthened, the greatest length is $4 \mathrm{~cm}$., consisting but of one stratum of sporangia, which is $1 \mathrm{~mm}$. thick. Wall of sporangium olive; the lateral wall towards ripening of the spores perforated by large, oval openings. Mass of spores olive; the single spore rather colourless. Spores in 
oval ball-shaped clusters of from 5-25. Only the convex surfase warted, 11-12 $\mu$ diameter.

Enteridium Rostrupii, Raunk., Myx. Dan., p. 106 (in English).

On fir-stumps and rotten oak branches-autumn.

Denmark.

From the above description alone it is difficult to indicate the points of difference between the present species and $E$. olivaceum.

\section{Enteridium macrosporum, Raunk.}

Aethalia hemispherical, $2 \mathrm{~mm}$. diameter, at first reddish, later olive. Spores in oval ball-shaped clusters of from 5-25. Only the convex surface spinulose, $12-14 \mu$ diameter.

Enteridium macrosporum, Raunk., Myx. Dan., p. 106, t. 2, f. 1 .

On rotten fir branches. Autumn. Near Copenhagen.

This species I have only found once, and then but very few specimens. It seems to be especially different from the other species of Enteridium in the size of the spores and the particularly developed sculpture of their convex surface. (Raunk.)

Enteridium Rozeanum, Wing. (f. 108).

Acthalium of irregular sliape, globose, ovoid, or roundedpyramidal, attached to the substratum by a wide base. Variable in size, from $5-30 \mathrm{~mm}$. in diameter. Cortex and mass of spores ferruginous brown; occasionally the cortex shining; sometimes membranaceous, pellucid. Interior structure very variable, the walls of the individual sporangia (which form a capillitium) membranaceous, pellucid, band-like, combined into an all-sided network attached uniformly to all sides of the cortex. The bands have triangular or polygonal expansions at the angles where they join each other. Spores globose, about two-thirds of the surface covered with a delicate, regular, fine-meshed network, the remainder with simple warts or elongated ridges. The warted portion has the outline of a wide spindle lying at the poles of the little sphere. Spores measure $7 \cdot 5-9 \mu$. 
Enteridium Rozeanum, Wing., Proc. Acad. Nat. Sci. Phil., 1889, p. 156.

Retieularia (?) Rozeana, Rost., Mon., Suppl., no. 179 ; Sacc., Syll., no. 1425.

Licea fallax, Pers., in Herb. Schwein.

On wood, bark, \&c. Britain (Scarboro'); France; United States.

The spaces in the capillitium, which represent the individual sporangia of the aethalium, have about the same dimensions in the same plant, but vary considerably, comparing one specimen with another. The extremes of variation may be expressed by the proportion 1 to 10 . Sometimes the bands of the capillitium are very much lacerated longitudinally, and form a filamentous mass, when the characteristic structure of the genus is entirely lost after the dispersal of the spores. Capillitium yellowish under the microscope.

The whole of the above is from Mr. Wingate's article, which also contains an interesting historical sketch of the species.

The present species appears to be generally distributed in the United States, judging from the specimens in the Kew herbarium sent by various American correspondents; one specimen communicated by Ravenel from Lower Carolina is irregularly circular "in outline, three and a half inches in diameter and half an inch thick. The European form, judging from the specimens I have seen, has the sporangial walls very much reduced, and will probably be found in herbaria under Reticularia, where I was at first disposed to place it until convinced by Mr. Wingate of its nearer affinity with Enteridium.

\section{B. Spores warted.}

\section{Enteridium simulans, Rost.}

Very sinnilar to E. olivaceum, but the spores are free or loosely aggregated, irregularly spherical, and minutely warted all ovcr, $10-12 \mu$ diameter.

Rost., Monogr., Appendix, p. 31; Karst., Myc. Fran., iv. p. 126 ; Sacc., Syll., n. 1400. 
On decorticated branches of Alnus incana. Finland.

Aethalium variable in form, suborbicular or elongated, convex, pulvinate or depressed, $2-5 \mathrm{~mm}$. broad.

I have had no opportunity of examining, the present species. If the spores are minutely warted all over, the species may be distinct, but clustered spores with warts all over are not common; and remembering the numerous inaccurate descriptions in the works of Karsten and Rostafinski in connection with epispore marking, I am inclined to suspect the autonomy of the present species.

\section{OrCadella, Wing.}

Sporangia with coarse stipes; sporangium wall likewise coarse, but at the top of the sporangium replaced by a delicate membrane which forms a more or less flattened deciduous lid.

Orcadella, Wingate, in Proc. Acad. Nat. Sci. Philada., 1889, p. 280.

The present genus is considered as the type of a new family of the Myxogastres, described as follows by Mr. Harold Wingate in the article quoted above-

"This curious minute plant presents anatomical characteristics which lead me to propose a new family of the Myxomycetes, and which, in Dr. Rostafinski's classification, would come under Order IV., Anemcac, and after Family 13, Clathroptychiaceae.

"Orcaulellaceae, fam. nov.

"Sporangia without columella or capillitium, and the upper part of the coarse sporangium wall replaced by a delicate membrane having a defined outline.

"This family seems to bridge, to a certain extent, the gap between Rostafinski's orders Anemeae and Heterodermeae, as we here have a stage between the uniform wall of Licea, Tubulina, \&c., and the lacerate upper wall of some species of Cribraria, where the receptacle is strongly developed and covered with minute granulations. The epispore seems to be absolutely without thickenings even under very high magnification." 
I am indebted to the kindness of the author for an opportunity of examining authentic specimens, and quite agree as to the validity of the generic characters, and also admit that the new family founder is quite as good as most others at present admitted in the Myxomycetcs, but I am afraid that if such trivial characters are admitted as sufficient for family characteristics, those left for generic distinctions will be reduced to inappreciable quantities.

Compared with allied genera, as Clathroptychium and Enteridinu, we find that in the genus under consideration, the apical portion of the sporangium is differentiated and eventually disappears, whereas in the two last-named genera the differentiation and disappearance of the sporangium is confined to certain portions of the latcral wall; or finally, it may be looked upon as a scattered, stipitate Tubulina with a dehiscent apex to the sporangium.

Distrib. United States: species 1.

Orcadella operculata, Wing. (f. 201).

Sporangia stipitate, without columella. or capillitium, very variable in form, barrel-shaped, urn-shaped, vase-shaped, jarshaped, ovoid or nearly globose, or all varieties appearing in one small group; stipe slightly tapering, erect or bent; blackish, rough and coarse from deposits of plasmodic refuse; very variable in height. Sporangium wall likewise coarse, blackish, containing deposits of plasmodic refuse, but at the top part of the sporangium replaced by a delicate, yellowish, iridescent, lustrous or vernicose membrane which forms a flat or slightly convex circular deciduous lid, sometimes smooth, sometimes reticulately wrinkled. Máss of spores yellowish. Individual spores almost colourless, globose or irregularly roundish, smooth, $8-11 \mu$ in diameter.

Orcadella operculata, Wing., Proc. Acad. Nat. Sci. Phil., 1889, p. 280, with fig.

(Type in Herb. Acad. Nat. Sci. Philada.)

On trunks of living red-oak trees (Quercus ruber). United States. 
I have given the author's own diagnosis of the species. Scattered in cracks of the bark, from $5-1 \mathrm{~mm}$. high, sometimes a little more, stem suberect, sometimes rather flexuous, sporangium very small.

\section{Clathroptychium, Rost.}

Aethalium naked; sporangia sessile, prismatic or cylindrical, densely crowded on a hypothallus, walls of sporangia persistent at the apex, lateral walls reduced to $5-6$ slender threads which extend from the hypothallus and support the apical portion.

Rost., Mon., p. 225; Cooke, Myx. Brit., p. 55 ; Schroeter, p. 164; Sacc., Syll., p. 405 ; Zopf, p. 137.

Rostafinski was the first to point out the true aethalioid nature of Clathroptychium rugulosum, and in his diagrammatic arrangement, Mon., fig. 30, represents the sporangia as circular in outline, packed close together, and consequently leaving triangular interspaces; each sporangium is represented as having six triangular thickened portions of its wall projecting into the interior of the sporangium. A careful examination of several specimens in various stages of development show that Rostafinski's interpretation is not correct. The sporangia, when young, are cylindrical, with both ends slightly convex, and the walls entire; towards maturity the lateral walls, due to mutual pressure, become flattened, and the sporangia are then hexagonal or rarely pentagonal in transverse section; at the angles where three contiguous cells meet the walls of the sporangia become thickened, agglutinated together, and persist as the upright threads that support the slightly convex, persistent, cap-like portions of the sporangia. From the above description it will be seen that the triangular upright threads correspond in position to the triangular interspaces in Rostafinski's diagram, and further, that the black triangular thickenings shown in the diagram have no existence in nature. During the period between the formation and maturing of the spores, the flat lateral walls of the sporangia are dissolved, with the exception of a narrow jagged wing projecting from each angle of the upright permanent portions. In C. rugulosum these wings are 
very rudimentary, but in $C$. Berkeleyi are often broader than the triangular portion, and recalling to mind the similar structure in Enteridium olivaceum. The triangular upright threads almost invariably show traces of a central cavity, which corresponds to the intercellular space between the originally cylindrical sporangia. The persistent apices of the sporangia, when viewed from above under a low power, are seen to consist of very slightly convex hexagons, rarely pentagons, so firmly agglutinated together that the whole can be removed as a continuous membrane; if this is done, and the membrane then viewed from the under side, after the spores have been cleared away, the stumps of the triangular threads will be seen to originate from the angles where the permanent apices of three sporangia meet; if this membrane is treated with potassie hydrate, the apices separate from each other as do also the triangular threads; this separation sometimes takes place in water alone, when the apices with their threads appear as represented in Rostafinski's figures 28 and 29.

The above account applies to the typical structure, but both species appear to be very variable. Zopf has figured an aberrent form of C. rugulosum, having the threads supporting the apical persistent portion of the sporangium varying in number, irregularly branched and anastomosing. I have met with a similar form, also another variety where the threads are branched and anastomosing and not confined to the margin of the apical portion, but originating from any portion of its under surface, and approximating so closely in structure to certain forms of the genus Perichaena as to be almost indistinguishable.

Distrib. Europe; Africa; India; Ceylon; Australia; United States: species 3.

Clathroptychium rugulosum, Rost. (f. 25-28).

Hypothallus well developed, often extending as a whitish membrane for some distance; sporangia prismatic, apex slightly rounded, and supported by five or six slender triangular persistent threads, the flat face pointing to the interior of the sporangium rugulose; colour of mass of sporangia reddish, bright 
brown, or umber; mass of spores clear yellow, ochraceous, or tinged with brown, spores globose, very minutcly vcrucuculose, 8-11 $\mu$ diameter.

Rost., Mon., p. 225, figs. 25, 28, 29, 30; Cooke, Myx. Brit., p. 5 j, figs. 25, 28, 29, 30 ; Schroeter, p. 104.

Licca tenuissima, B. and Br., Fungi of Ceylon, in Journ. Linn. Soc., Vol. xiv., p. 86 (Hb. B., n. 10858).

Licea cinnabarina, B. and Br., Ceylon Fungi, in Journ. Linn. Soc., Vol. xiv., p. 86 (Herb. Berk., 10854).

Ostracoderma spadiccum, Schwein. (specimen so named by Schweinitz in Herb. Berk., 10864).

Cornuvia Schwcinitzii, Berk. in Herb.

Exsicc.-Ellis, N. Amer. Fung., 33 J.

On dead wood. Britain (Oxford, Leicester, Eltham Park, Scarborough, Glamis, N. B.) ; France; Germany; Italy ; Belgium; Hungary; Algeria; United States; Ceylon; Australia.

The crowded sporangia form compact cakes of irregular form, varying from a $\frac{1}{2}$ to $1 \frac{1}{2} \mathrm{in}$. across, and about $1 \mathrm{~mm}$. thick. The surface is generally chestnut-brown, often with olive shade, and minutely rugulose. The hypothallus often extends considerably beyond the sporangia. Differs from $C$. cinnabariunm iu the verruculose spores, and from $C$. Berkeleyi in the absence of wings to the triangular supports of the apex of the sporangium.

(Rostafinski's Synonyms.)

Fuligo plumber, Fl. Dan., 1976, f. 1 (1803).

Reticularia plumbea, Fr., S. M., iii. 88 (1829).

Licea mugulosa, Wallr., Fl. Germ., 2107 (1833).

Licca applanata, Berk., Hook Journ. (1845); B. and Br., Ann. Nat. Hist., n. 313 ; Cke, Hdbk., n. 1195.

Lycogala lenticulare, D. R. and M., Fl. Alg., 401 (1846).

Reticularia lenticularis, Mort., Herb.

Dictydiaethalium applanatum, Rost., in Fckl., Symb., 2 Nach.

69 (1S73). 
Clathroptychium Berkeleyi, Mass. (n. sp.).

Hypothallus stout, not extending beyond the sporangia, which are densely crowded, forming cakes $1-3 \mathrm{~cm}$. across, and $1.5-2 \mathrm{~mm}$. thick, very minutely and indistinctly rugulose, brownish-olive; apices of sporangia almost plane, supported by 5-6 triangular, hollow threads, which are strongly winged at the angles, free edges of wings eroded; mass of spores dirty olive; spores globose, warted, warts with a tendency to become elongated, 10-13 $\mu$ diameter.

Licea cylindrica, Fr., Berk. and Br., Fungi of Ceylon, Journ. Linn. Soc., Vol. xiv., p. 86.

On wood. Ceylon.

(Type in Herb. Berk., n. 10857 a.)

The large spores with the "warts showing a tendency to become elongated and form ridges, and the strongly-winged threads supporting the apices of the sporangia characterize the present species.

Clathroptychium cinnabarinum, Sacc.

Sporangia prismatic, broadly diffused, closely crowded, $\frac{1}{3}-\frac{1}{2} \mathrm{~mm}$. high, vivid vermilion, above (operculum) blackishpurple, rather shining, sessile, rising erect from a hypothallus; spores globose, smooth, 9-12 $\mu$ diameter, vermilion, guttulate; threads descending from the operculum, filiform, thickish, fuliginous.

3. Sacc., in Michelia, I., p. 545 ; Sacc., Syll., Vol. vii., pt. I., n. 1397.

On decayed oak wood. North Italy. Forming flattened heaps, 4-6 cm. long. Differs from Clathroptychium rugulosum in the different colour of the mature plant, the narrow, prismatic sporangia, and smooth, vermilion spores.

The vermilion colour and smooth spores suggest the possibility of the present being an immature condition of some species.

Clathroptychium dissiliens, Hazl.

Sporangia forming a rotund or oval cushion, 2-5 $\mathrm{mm}$. 
diameter, chestnut-brown, pruinose; mass of spores and supporting threads yellowish brown.

Dictydiathalium dissilicns, Hazl., Just.' Bot. Jahresb., 1877, p. 156 ; Sacc., Syll., Vol. vii., pt. I., n. 1398.

Hazlinsky states the present species, when ripe, dehisces in an elastic manner on the slightest touch, brought about by the sudden expansion of the elaters (= threads supporting apical portion of sporangium) which increase to three times their previous length.

Cribraria. Pers. (emended).

Wall of sporangium single, with thickened permanent portions arranged in the form of more or less parallel ribs at the base, branching and anastomosing above to form an irregular network, angles of network sometimes dilated and enclosing granules; thin portions of wall entirely disappearing at maturity, or the basal portions between the radiating ribs persistent and forming an imperforate calyculus; columella and capillitium absent.

Cribraria, Pers. Syn., p. 192; Rost., Mon., p. 57 ; Cooke, Myx. Brit., p. 57 ; Schroeter, p. 104; Zopf, p. 141 ; Sace., Syll., Vol. vii., pt. I., p. 412.

Heterodictyon, Rost., Mon., p. 231 ; Cooke, Brit. Myx., p. 57 ; Sacc., Syll., p. 411.

After a careful comparison of specimens or figures of all the species, with two exceptions, I find it impossible to retain Rostafinski's genus Hetcrodictyon. In Cribraria we find, as a rule, a calyculus at the base of the sporangium, composed of more or less parallel ribs, with the thinner intermediate portions persistent; from the irregular margin of the calyculus, the upper network commences, or rather, may be looked upon as a continuation of the ribs of the calyculus; if the upper portion starts from the margin of the calyculus, as an irregular net-work consisting of well-defined nodes united by thin strands, it represents Rostafinski's conception of Cribrarice; but if the lower portion of the network consists of more or less parallel, broad ribs, joined laterally by thin strands, and 
passing into the Cribraria type of network towards the apex, then, according to Rostafinski, it is Heterodietyon. There is, in reality, every shade of transition between the two extremes, and C. Bieniaszii closely connects the genus Cribraria in the wider sense, with Dictydium.

Distrib. Europe; United States; Ceylon: species 19.

Sub-Gen. Heteroderma. Calyeulus present. Network thickened, and forming nodes at the angles.

Cribraria elegans, B. and C.

Sporangia globose, stipitate, more or less cernuous, purple, calyeuhus occupying nearly lower half of sporangial wall, with numerous radiating ribs, and studded with organic purple granules inside; nodes of network numerous, large, angular or irregularly stellate, containing purple granules, connected by thin bands; stem elongated, expanding downwards, and passing into a small hypothallus, curved near the apex, purple; spores-mass purple; spores globose; minutely warted, $5-7 \mu$ diameter.

Cribraria elegans, B. and C., Grev., Vol. ii., p. 67 ; Sacc., Syll., n. 1412 ; Rost., Mon., App., p. 32.

(Type in Herb. Berk., n. 10873.)

On decayed wood. Lower Carolina.

Scattered or gregarious, stem variable in length, $2-3 \mathrm{~mm}$., sometimes flexuous. There are no free ends in the network of the sporangium.

\section{- Cribraria piriformis, Schrad.}

Sporangia pyriform, stipitate, erect, purple-brown before dehiscence, then yellowish-brown above, calyculus funnel-shaped, occupying the lower third of sporangium, with radiating ribs, margin eroded, nodes of network large, angular, coloured, with prominent, acute processes, containing granules, united by very slender threads; stem about equal in length to sporangium, subequal, purple-brown, expanding at the base into a hypothallus of the same colour; spores very pale salmon-colour, globose, smooth, $5-7 \mu$ diameter. 
Cribraria pirifornis, Schrad., Nov. Pl. Gen., p. 4, pl. 3., f. 4-5; Rost., Mon., p. 237, fig. '14; ; Cooke, Brit. Myx., fig. 14; Sacc., Syll., n. 1416.

On rotten pine wood. Scotland; Sweden; Germany.

Gregarious, several often springing from a common hypothallus; $2-3 \mathrm{~mm}$. high, resembling superficially some forms of C. macrocarpa, but at once distinguished by the large, irregularly stellate, distinct nodes of the network, connected by slender strands.

Cribraria macrocarpa, Schrad. (f. 110).

Sporangia troadly obovate, stipitate, erect, upper portion yellowish-broion, calyculus brownish-purple, funnel-shaped, occupying one-third or more of the sporangium; sometimes perforated towards the very irregular margin, the projections of which are prolonged as flattened, granulose, coloured, irregularly curved bands of varying width, and anastomosing at various points, with numerous lateral projections which are continuous with the projections of adjoining ribs as thin strands bridging the irregular meshes formed by the larger ribs; stem stout, erect, simple, or 2-3 more or less grown together, purplebrowon, rugulose, expanded at the base into a spreading hypothallus; spores pale yellow, globose, smooth, 7-10 $\mu$ diameter.

Cribraria macrocarpa, Schrad., Nov. Pl. Gen., p. 8, t. ii., f. 3-4 ; Cooke, Myx. Brit., p. 59 ; Sacc., Syll., n. 1417; Rost., Mon., p. 238.

On decayed wood. Britain (Glamis, N. B.); France; Switzerland; Germany; Sweden.

Crowded or scattered, sometimes $2-3$ more or less combined to form an aethalium. The obovate sporangia and peculiar structure of reticulation characterize the present species, the broad, flattened, primary ribs by irregular bifurcation, combine to form a network of irregularly elongated meshes, which are bridged over by lateral thin strands from the sides of the larger ribs. Well-defined distinct nodes connected by thin strands are absent. 


\section{(Rostafinski's Synonyms.)}

Critruria mucrocarpa, Schrad., Nov. Gen., p. 8, t. ii., f. 3-4 (1797).

Trichia macrocarpa, Poir., Ency., 1. c. viii., no. 30 (1808).

\section{Cribraria purpurea, Schrad. (f. 109).}

Sporangia globose, stipițate, dar\% purple, calyculus welldeveloped, with thickened ribs, sometimes irregularly perforated near the dentate margin; nodes of network containing purple granules, small, usually elongated, but very irregular in form, with numerous processes, connecting threads thin, some of the processes are prolonged into simple or branched irregularly bent threads that remain free at the tips, and not connected with other nodes or threads; stem elongated, flexuous, purple; sporemass dark purple, spores almost colourless, or with faint tinge of rose, globose, smooth, $5-7 \mu$ diameter.

Cribraria pur'purea, Schrad., Nov. Pl. Gen., p. 8; Rost., Mon., p. 233 ; Sacc., Syll., 1408.

On decayed pine trunks. Germany; Britain (specimen in Herb. Kew marked, "Herb. Dawson Turner, British "); Sweden (specimen collected by Lindblad, and communicated to Berkeley by Fries).

Gregarious or scattered, about $1.5 \mathrm{~mm}$. high, stem $3-4$ times as long as sporangium, usually more or less flexuous. Agrees in colour with C. elegans, but readily distinguished by the smooth spores and numerous free ends in the permanent network of the sporangium. Distinct from C. macrocarpa in the globose sporangium and long, slender, flexuous stem.

\section{Cribraria aurantiaca, Schrad. (f. 104).}

Sporangia globose, usually more or less cernuous, orange brown, calyculus occupying one-third or more of the sporangial wall, furnished with ribs which pass upwards to form the network, nodes coloured, containing granules, large, irregular, united by thin, colourless bands; stem elongated, attenuated upwards, where it is curved, bright brown, expanding at the base into a 
small hypothallus; mass of spores dark orange; spores globose, smooth, $5-7 \mu$ diameter.

Cribraria aurantiaca, Schrad., t. i., f. 3-4; Rost., Mon., 22.3, f. 21; Cooke, Myx. Brit., p. 58, fig. 21 ; Schroet., p. 105; Raunk., p. 50 ; Sacc., Syll., 1409.

On decaying wood, especially pine. Britain (Carlisle, Aboyne, Linlithgow); Sweden; Germany; Belgium; Hungary.

Gregarious or scattered, $2-2.5 \mathrm{~mm}$. high; the nodes of the network of the sporangial wall are numerous, large, and very irregular, usually irregularly stellate, the rays tapering gradually and without much smooth internode, again expanding as a ray of an adjoining node. Spores sometimes minutely verruculose under a high power.

\section{(Rostafinski's Synonyms.)}

Cribraria aurantiaca, Schrad., t. i., f. 3-4 (1797); Fr., S. M., iii. 174; Cke., Hdbk., 1169 ; B. and Br., Amn. Nat. Hist., 1037. Cribraria vulgaris, $\beta$ aurantiaca, Pers., Syn., 194 (1801).

Trichia mufescens, $\beta$ aurantiaca, Poir, Ency., viii. 31.

Cribraric aurentiaca y sulphurea, Wallr., Fl. Germ. (1833).

Cribruria intermedia, Berk., Eng. Fl. v., 318 (18:36); Cooke, Hdbk., 1166.

Cribraria ravicebilis, Ficinus Dresd., Fl. 269 (1838).

\section{Cribraria tenella, Schrad.}

Sporangia spherical, generally more or less cernuous, stipitate, calyculus occupying about half the sporangium, broun, shining, often perforated above, margin irregularly eroded, nodes numerous, coloured, containing granules, small, more or" less circular in outline, connected by very delicate strands; stem elongated, slender, subequal, often flexuous, brown, with a tinge of purple; spores globose, almost colourless, smooth, 5-7 $\mu$ diameter.

Cribraria tenella, Schrad., Nov. Pl. Gen., p. 6, t. iii., f. 2-3; Rost., Mon., p. 235, f. 23; Cooke, Myx. Brit., fig. 23; Sclıroeter, p. 105 ; Sacc., Syll., no. 1411.

On rottun wood. Germany; Sweden; Italy. 
Gregarious, $1.5-2 \mathrm{~mm}$. high, resembling superficially $C$. intricata, but distinguished by the nodes of the network being almost circular in outline, and without the prominent angles from which the delicate strands spring in the last-named species.

Cribraria intricata, Schrad. (f. 11-13).

Sporangia globose, erect, stipitate; ochraccous brown, calyculus occupying half the sporangium, margin dentate, nodes of network numerous, containing granules, coloured, irregularly angular, with several large, pointed, marginal projections, connected by very delicate strands, often arranged in more or less parallel series; stem erect, attenuated upwards, brown, with usually a purple tinge; spores pale, globose, wall thick, smooth, $5-7 \mu$ diameter.

Cribraria intricata, Schrad., Nov. Pl. Gen., p. 7, t. iii., f. 1; Rost., Mon., p. 237, fig. 27; Cooke, Brit. Myx., p. 59, f. 27 ; Raunk., p. 50, t. ii., f. 7 ; Sacc., Syll., n. 1415.

On rotten wood, especially pine. Britain (Lyndhurst, Weybridge, Carlisle, Glamis, N. B.); Germany; Sweden; United States.

Gregarious or crowded, $2.5-3 \mathrm{~mm}$. high; distinguished amongst species with a large, hemispherical calyculus, by the large, angular, irregularly stellate nodes of the network being connected by slender bands, which are often arranged in parallel pairs.

(Rostafinski's Synonym.)

Cribraria intricata, Schrad., Nov. Pl. Gen., p. 7, t. iii., f. 1 (1797).

Cribraria minima, B. and C.

Sporangia globose, cernuous, stipitate, dusky ochraceous, calyculus hemispherical, margin irregularly toothed, thickened, ribs rudimentary; nodes of network numerous, irregularly stellate, coloured, not containing granules; stem elongated, attenuated upwards, brownish; spores globose, almost colourless, smooth, $5-7 \cdot \mu$ diameter. 
Cribraria minima, B. and C., Grev., Vol. ii., p. 67.

Cribraria minutissima, Rost., Mon., App., p. 31 ; Sacc., Syll., n. 1405 (in part).

(Type in Herb. Berk., n. 10874.)

On pine planks. Lower Carolina.

Scattered, about $\frac{2}{3} \mathrm{~mm}$. high, stem erect, or usually curved above. Perfectly distinct from $C$. minutissima in the presence of a well-developed calyculus occupying the basal half of the sporangium. Most nearly allied to C. intricata, which is distinct in its larger size, presence of granules in nodes of network and minutely warted spores. Rostafinski has evidently not seen the type specimen of the present species, otherwise he could not possibly have given it as a synonym of $C$. minutissina.

Cribraria mirabilis, Mass.

Sporangium spherical with a small, irregular calyculus; persistent thickencd portions of wall continuing for some distance from the base as more or less parallel, irregular, flattened ribs, joined laterally by thin threads, towards the apex forming an irregular network with large, irregular nodes; mass of spores obscure fulvous, spores smooth, $7 \mu$ diameter.

IIcterodictyon mirabile, Rost., Mon., p. 231, fig. 16; Cooke, Myx. Brit., fig. 16 ; Sacc., Syll., no. 1403.

Germany.

The characteristics of the present species are-the small, irregular calyculus, and the great length of the more or less parallel flattened ribs, which only break up to form a reticulation towards the apex of the sporangium.

\section{Cribraria Bieniaszii, Mass.}

Sporangia globose, stipitate, bronon, calyculus oceupying the loner third of the sporangium, on the inside furnished with a thickened network, margin dentate, teeth $30-40$, continuing upuards as long, linear, parallel ribs united by very thin horizontal strands, passing above into a Cribraria-like networl, nodes small with from 3-6 angles and concave sides; stem elongated, becoming attenuated upwards, lrown, expanding into a small 
hypothallus; spores clear yellow, wall smooth, thin, 5-7 $\mu$ diameter.

Heterodictyon Bieniaszii, Racib., Hedw. 1889, p. 121.

On rotten trunks. Poland.

Stem $1.5-2.5 \mathrm{~mm}$. high, sporangium $0.8-1 \mathrm{~mm}$. diameter.

Distinguished from C. mirabilis by the larger sporangium and the greater number of ribs forming the lower part of the network.

\section{Cribraria vulgaris, Schrad.}

Sporangia globose or slightly flattened below, stipitate, calyculus shallow, ribs very thin, parallel, crowded, margin regularly dentate, the very thin threads of the network springing from the teeth of the calyculus, and combining to form a dense net, nodes distinct, but very small, rarely containing a few granules; stem slender, elongated, often rather flexuous, brown, with tinge of purple, becoming thicker downwards and expanding into a small hypothallus; spores very pale, globose, smooth, $5-7 \mu$ diameter.

Cribraria vulgaris, Schrad., Nov. Pl. Gen., p. 6, t. i., f. 5; Rost., Mon., p. 234, f. 26; Cke., Brit. Myx., fig. 26 ; Schroeter, p. 105 ; Karst., Myc. Fenn. iv., p. 85 ; Sacc., Syll., no. 1410.

Exsicc. Rab., Fung. Eur., 676; Fckl., Fung. Rhen., 2100.

On decayed wood, especially pine. Germany; Sweden; Finland.

Gregarious, about $1 \cdot 5-2 \mathrm{~mm}$. high. Stem straight or curved above. The features of the present species are-the shallow calyculus with thin, crowded, parallel, or more accurately, radiating ribs, and the very small knots of the network.

\section{Cribraria elata, Mass.}

Sporangia globose, erect or sub-cernuous, stipitate, calyculus small, funnel-shaped, radiating ribs well-developed, margin regularly dentate, tceth elongated, acute, nodes of network numerous, coloured, irregularly angular, crowded with granules, with several prominent, tapering processes, connected by very slender bands; stem with the calyculus dark reddish-brown, elongated, 
erect or slightly curved above, becoming thicker downwards and expanding into a small hypothallus; spores pale yellow brown, globose, smooth, $7-8 \mu$ diameter.

On wood and twigs. Ceylon.

(Type in Herb. Berk., Kew, no 10871.)

Gregarious, $3-3.5, \mathrm{~mm}$. high, superficially resembling $\mathrm{Cr}^{\circ}$ braria microcarpa, but distinguished from this and all other species by the small, funnel-shaped calyculus with the very long, tapering, marginal teeth. The spores sometimes show a tendency to granulation under a high power.

* Network not thickened at the angles.

Cribraria microscopica, B. and C.

Sporangia broadly obovate or globose, stipitate, calyeulus occupying almost the lower half of the sporangium, withont rib-like thickenings, permanent ribs of upper portion thin, equal, without granules, not incrassated at the angles, combined to form large, irregular polygons of about equal size; stem abont equal in length to sporangium, ereet, brownish umber: spores globose, smooth, 6-7 $\mu$ diameter.

Cribraria microscopica, Berk. and Curt., Grev., Vol. ii., p. 67 ; Sacc., Syll., 1406.

(Type in Herb. Berk., n. 10175.)

On shingles. South Carolina.

Scattcred, about $1 \mathrm{~mm}$. high, stem about equal to sporangium in length, expanding at the base into a minute hypothallus. Every part dingy ochraceous. Distinct from C. minima in the absence of thickened nodes in the network of the sporangium.

\section{Cribraria tatrica, Racib.}

Sporangia globose, rufous-brown, stipitate, stem obscure rufous, straight; lower part of sporangium persistent, forming a ealyculus with the margin irregularly crenato-dentate; persistent thickenings of upper portion of sporangium about equal, not thickened at the nodes; spores yellow, globose, smooth, $6-7 \mu$ diameter. 
Cribraria tatrica, Racib., Hedw., 1885, p. 170; Sacc., Syll., n. 1407.

On rotten wood. Hungary (Tatra).

Sporangia $\frac{3}{4}-1 \mathrm{~mm}$. diameter, stem $2 \mathrm{~mm}$. long.

Cribraria rufa, Rost. (f. 103).

Sporangia broadly obovate or sub-globose, stipitate, orangerufous, calyculus well-developed, occupying one-third or more of the sporangium, furnished with radiating ribs, which extend above and combine to form a more or less regular net not thickened at the angles; stem brown, often with a purple tinge, elongated, erect, attenuated upwards, expanding at the base into a small hypothallus; - spores pale brown, often with a decided purple tinge, smooth, $5-7 \mu$ diameter.

Cribraria rufa, Rost., Mon., p. 232, f. 15; Cke., Brit. Myx., p. 58, f. 15; Schroeter, p. 105; Sacc., Syll., n. 1404; Raunk., p. 49 , t. ii., f. 5 .

On wood. Britain (Epping, Carlisle, Linlithgow); Germany; Sweden; Denmark.

Gregarious, 2-3 mm. high.

(Rostafinski's Synonyms.)

Stemonitis rufa, Roth., Fl. Germ., 548 (1788).

Cribraria rufescens, Pers. disp., t. i., f. 5 (1797).

Cribraria fulva, Schrad., t. i., f. 1 (1797).

Cribraria intermedia, Schrad., t. i., f. 2 (1797); Berk. and Br., Ann. Nat. Hist., no. 1601.

Trichia rufescens, Poir., Ency., viii., no. 31 (1808).

Sub-Gen. Homoderma. Calyeulus absent.

* Network thickened and forming nodes at the angles.

Cribraria microcarpa, Rost. (f. 134-136).

Sporangia globose, small, erect or cernuous, stipitate, calyeulus absent, primary ribs of network radiating from apex of stem as elongated, broad bands, anastomosing laterally and forming elongated meshes passing upwards into an irregular network of 
very thin threads connecting large, brown, irregularly stellate knots crowded with granules; stem slender, very much elongated, straight or flexuous, erect or curved above, brownish purple; spores very pale, globose, minutely verruculose, $5-7 \mu$ diameter.

Cribraria microcarpa, Rost., Mon., p. 236 ; Schroeter, p. 105 ; Karst., Myc. Fenn., iv., p. 86; Sacc., Syll., no. 1413.

Exsicc.-Ellis, North Amer. Fung., 1398 (as Cribraria tenella, Schrad.); Rav. Fung. Car., 79 (as $C$. intricata).

On decayed pine-wood and on sphagnum. Britain (Clevedon, Bristol); Germany; Sweden ; Finland; United States.

Gregarious, $25-3 \mathrm{~mm}$. high. Distinguished amongst species without a calyculus by the small sporangium and elongated stem; also by the elongated, flattened, radiating ribs at the base of the network, thus approaching the type of structure on which Rostafinski's genus Heterodictyon was founded.

\section{Cribraria splendens, Rost.}

Sporangia globose, stipitate, erect, yellowish, calyculus not differentiated, membrane between the thickened portions for a long time persistent; nodes large, angular, containing granules; stem elongated, slender, sometimes flexuous, purple-brown; spores pale yellow, globose, smooth, $5-7 \mu$ diameter.

Cribraria splendens, Rost., Mon., p. 236 ; Karst., Myc. Fenn., iv., p. 85; Raunk., Myx. Dan., p. 50, t. ii., f. 6; Sacc., Syll., n. 1414 .

On rotten pine-wood. Germany; Finland; Sweden; Switzerland.

Scattered, about $2 \mathrm{~mm}$. high, stem about three times as long as sporangium. Distinguished by the very persistent nature of the membrane between the thickened portions.

\section{(Rostafinski's Synonyms.)}

Dictydium splendens, Schrad., Nov. Pl. Gen., p. 14, t. iv., f. 5 -6 (1797).

Cribraria splendens, Pers. Syn., p. 191 (1801).

Trichia splendens, Poir., Ency., l. c. viii., no. 28 (1808). 
Cribraria dictydioides, Cke. and Balf.

Sporangia globose, stipitate, dingy ochraceous, calyculus absent; permanent ribs broad and flattened below, anastomosing laterally, filled with granules, passing upwards into numerous elongated or irregularly angular, prominently convex, coloured nodes containing granules, and connected at various points by very thin, colourless threads; stem elongated, slightly thinner upwards, straight or flexuous, from dirty ochraceous to brown; spores globose, almost colourless, minutely verrucose, $5-7 \mu$ diameter.

Cribraria dictydioides, Cke. and Balf., Rav. Fung. Amer., 475 .

(Type in Herb. Kew.)

On wood. Aiken, S. Carolina, and Philadelphia, U. S.

Gregarious, about $3 \mathrm{~mm}$. high. The permanent portion of the sporangium closely resembles that of $C$. argillacea, but in the latter the spores are warted and the sporangium sessile. The present species also agrees with $C$. microcarpa in the absence of a calyculus, but in the last-named species every part of the permanent portion consists of irregularly stellate nodes connected by thin bands, and the spores are warted. In $C$. dictydioides, the nodes of the upper portion of the network are convex and very prominent. The stem is sometimes branched, or composed of two or three stems more or less completely blended together.

Cribraria argillacea, Pers. (f. 105-107).

Sporangia crowded or scattered, shortly stipitate or sessile, subglobose or broadly pyriform, thin portions of sporangium very persistent, dirty ochraceous, shining, calyculus absent; thickened portions of sporangium in the form of long, more or less parallel, laterally connected ribs, passing upwards into an irregular network with irrcgular nodes containing granules; the internodes have frequently a central, swollen, fusiform, granular portion; mass of spores dingy ochre; spores globose, minutcly warted, $5-7 \mu$ diameter. 
Cribraria argillacea, Pers., Obs., i., p. 90 ; Rost., Mon., 239 ; Cooke, Myx. Brit., 59; Sacc., Syll., 1418; Raunk., p. 51, t. ii., f. 8.

Exsicc.-Cooke, Fung. Brit., ser. ii., 526.

On wood. Britain (Smethwick, Brandon, Carlisle); Germany; Denmark; France; United States.

Characterized by the sessile or subsessile sporangia, absence of calyculus, and in the granular swellings of the thickened portions of the capillitium not being confined to the nodes.

\section{(Rostafinski's Synonyms.)}

Stemonitis sphaerocarpa, Schr., Bot. Mag., xii. 20 (1790).

Stemonitis argillacea, Pers., in Gmel., 1409 (1796).

Cribraria argillacea, Pers., Obs.,.i. 90 (1796); B. and Br., Ann. Nat. Hist. (1865), no. 1036; Cooke, Hdbk., 1168; Fung. Britt., ii. 526.

Cribraria micropus, Schrad., t. ii., f. 1-2 (1797).

Trichia argillacea, Poir., Ency., viii., no. 32 (1808).

* Network not thickened at the angles.

\section{Cribraria minutissima, $\mathrm{Sz}$.}

Sporangia globose, stipitate, calyculus absent, permanent ribs thin, forming a more or less uniform reticulation; angles not at all, or very slightly enlarged: rarely enclosing a few granules; stem filiform, larger than sporangium, erect or curved above, brownish; spores globose, almost colourless, minutely warted, $4-6 \mu$ diameter.

Cribraria minutissima, Schweinitz, in Syn. Fung. Amer. Bor., no. 2362; Rost., Mon., App., p. 31 (Excl. Syn. C. minima, B. and C.); Sacc., Syll., 1405 (Excl. Syn. C. minima, B. and C.).

(Specimen in Hb. B. from Schweinitz.)

On decaying pine wood. United States.

Scattered, very minute, from $5-1 \mathrm{~mm}$. high, recognized at once by the absence of a calyculus and absence of enlarged, 
angles in the network. Stem from 2-3 times as long as sporangium.

\section{Dictydium, Schrad.}

Wall of sporangium single; permanent rib-like thickened portions radiating from base to apex and joined by numerous thinner transverse bands; thinner portions of wall situated between the ribs disappearing at maturity, or persistent at the base and forming an imperforate calyculus; columella and capillitium absent.

Dictydium, Schrad., Now. Gen. Pl., p. 11; Rost., Mon., p. 229; Cooke, Myx. Brit., p. 57 ; Sacc., Syll., p. 410; Zopf, p. 140 .

The primary, vein-like, permanent portions of the sporangium radiate from the base and converge at the apex without becoming much broken up or distorted, although there is usually an indication of a reticulate arrangement near the apex; these primary ribs are united laterally by straight, thinner portions, hence the arrangement of the skeleton is into more or less regular rectangular meshes.

Distrib. Europe; N. America; S. America; Ceylon; Australia : species 2 .

\section{Dictydium cernuum, Nees. (f. 133).}

Sporangium globose, cernuous, more or less umbilicate at the apex, reddish brown; stem elongated, slightly thinner upwards, with a sharp curve near the apex, above which the stem is hyaline and shrivelled at maturity; below the curve dark brown, opaque, smooth, passing into a small hypothallus; calyculus small; mass of spores purple brown; spores globose, smooth, 5-7 $\mu$ diameter.

Dictydium cernuum, Nees., Syst., f. 117; Rost., Mon., p. 229, figs. 17, 19, 22; Cooke, Myx. Brit., p. 57, figs. 17, 19, 22 ; Sacc., Syll., no. 1401 ; Schroeter, p. 106; Raunk., p. 51, Tab. ii. fig. 4 .

Dictydium cornuum, var. laxum, B. and C., Grev. 1873, p. 67. Exsicc.-Fuckel, Fung. Rhen., 1445 and 2099; Syd., Myc. 
March., 164; Rab., Fung. Eur., 2519; Jack, Leiner. \&c., 422 ; Rav., Fung. Car., 78 ; Rav., Fung. Amer., 476 ; Ellis, N. Amer. Fung., 1122.

On decaying wood, especially pine. Britain (Milton, Norths; Kew, Suffolk, Scarboro', Carlisle, Appin, N. B.); Germany; Sweden; Finland; Belgium; Denmark; Hungary; United States; S. America; Ceylon.

Gregarious, $1-1.5 \mathrm{~mm}$. high; the stem varies from $2-3$ times as long as the sporangium; the lower three-fourths is erect, blackish-brown, and opaque; at the top of this erect portion there is a sharp curve, above which the pendulous portion of the stem consists, at maturity, of a colourless, shrivelled membrane, from which the sporangium hangs suspended, and easily moved by wind or insects; in all probability this peculiar structure of the stem is connected with sporedissemination. The inner surface of the calyculus and the ribs are furnished with numerous dark brown granular masses of organic matter.

(Rostafinski's Synonyms.)

Mucor cancellatus, Batsch, f. 232 (1789).

Stcmonitis canccllata, Gmel., Syst., 1468 (1791).

Sphacrocarpmes trichioides, Bull., p. 124 (1791).

Cribrueriu cernua, Pers., Obs., i. 91 (1796).

Dictydium mmlilicatum, Schrad., t. iv., f. 1 (1797); Fr., S. M., iii. 165 ; Berk., Eng. Fl., v. p. 318; Cooke, Hdbk., 1165, fig. 134 .

Dictydizm ambiguum, Schrad., t. iv., f. 2 (1797).

Trichia cernua, Poir., Ency., viii., no. 25 (1808).

Dictydium ccrnuum, Nees., f. 117 (1816).

Dictydium trichioides, Chev., Fl. Par., 327 (1827); Corda Ic., v., f. 36.

Dictydium venosum, Schrad.

Sporangium globose, cernuous, brownish-yellow owing to the spore-mass showing through the translucent wall, which is 
almost colourless when empty and furnished with $9-12$ darker coloured ribs giving off lateral, free, not anastomosing branches; stem elongated, flexuous, brownish.

Dietydium venosum, Schrader, Nov. Gen., p. 14, pl. iii., fig. 6 ; Sacc., Syll., v. 7, pt. I., no. 1412 ?

On rotten prostrate trunks of pine. Germany.

It is doubtful whether the species described by Berlese in Sacc., Syll., l. c., is the species intended by Schrader.

\section{COLUMELLIFERAE. .}

The most pronounced features of the present section are the presence of a central columella, which in most instances is a direct continuation of the stem within the peridium, and the absence of lime from every part. The two sub-sections as defined appear distinct, but this, as usual, is only true of the two poles, and curiously enough, transitions have been met with where they would have been least expected. In the Lamprodermeae, characterized by the capillitium springing from the apex of the columella, we find this character fairly satisfactory in the typical genus Lamproderma, and yet more rigidly carried out in Enerthenema, where the copious capillitium originates entirely from a peltate disc springing from the apex of the columella after the latter has passed quite through the sporangium; yet we find in the genus Ancyrophorns all the characteristics presented by the genus Enerthenema, plus a few scattered branches springing from various points of the columella throughout its length, in addition to the main bulk of the capillitium which originates from the apical disc as in Enerthenema. The branches of the capillitium springing from the columella are again broken up into smaller and smaller branchlets, which usually combine to form an irregular network. The sporangial wall is always very thin and blackish in colour and remarkable for its brilliant metallic tints, and also for its ephemeral nature, disappearing entirely or in part as the spores approach maturity, or as in the genus Orthotrichia being absent 
from the earliest condition. In Lamproderma violaceum the columella is filled with large spherical, or from mutual pressure, polyhedral cells, a character repeated in the stem of several species of Arcyria. The three genera Amaurochaete, Brefeldia, and Reticularia are only known in the aethalioid condition, and superficially appear quite isolated from the remaining genera, but structurally are nothing more than confluent forms of such genera as Stemonitis and Lamproderma. Comatricha confluens is a connecting link between the two extremes. According to the preconceived idea that the presence of a columella is of sectional importance, the genus Siphoptychium belongs to the present division, nevertheless its affinity with the Peritricheae is obvious.

The following arrangement indicates the affinities of the genera included in the Columellifcrae, and the points of contact with other sections.

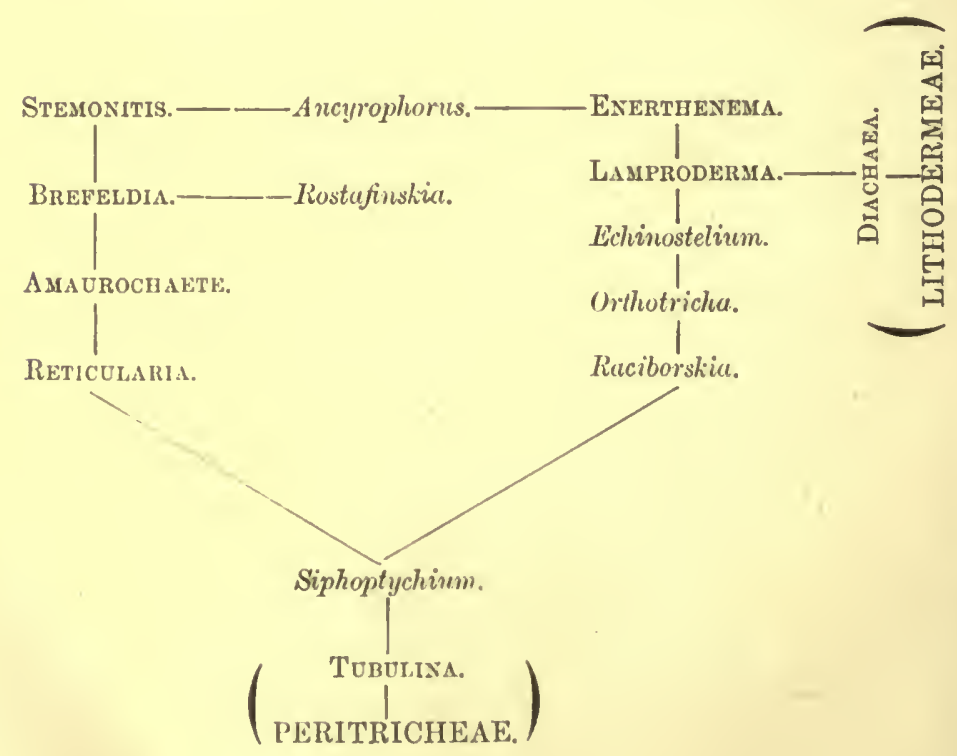




\section{ANALYSIS OF THE GENERA.}

\section{Sub-sect. Stemonitae.}

A. Sporangia free.

Stemonitis. Capillitium threads springing from all sides of an elongated columella.

\section{B. Sporangia forming an aethalium.}

Siphoptychium. Sporangia straight, parallel, each containing a central columella.

AMAURochaETE. A large, pulvinate aethalium, bifurcating branches of capillitium connected for some distance by a thin membrane.

BREFELDIA. Aethalium large, threads of capillitium with clusters of vesicular bodies.

Rostafinskia. Threads of lower portion of capillitium septate.

RETICULARIA. Aethalium pulvinate; capillitium threads forming an irregular network without vesicles or flat membranous expansions.

\section{Sub-sect. LAMPRODERMAE.}

ENerthenema. Threads of capillitium springing from a flattened disc at the apex of the columella.

Ancyrophomes. Threads of capillitium springing from a flattened disc at the apex of the columella, and also from the columella throughout its length.

LAMPRODERMa. Threads of capillitium springing from the abrupt apex of the short columella.

Echinostelium. Columella absent; capillitium springing from apex of stem.

Raciborstia. Wall of sporangium absent, main branches of capillitium springing from apex of a short columella, becoming branched, branches forming a network.

Orthotricha. Sporangial wall absent from the first. 


\section{Sub-sect. I. Stemontrae.}

\section{Stemonitis, Gled.}

Sporangia cylindrical, ovate, or globose, stipitate; stem continuing into the sporangium as a eolumella of greater or less length, and giving origin to numerous branches throughout its length, which combine to form a dense, irregular network; wall of sporangium thin, soon disappearing, often with metallic tints.

Stemonitis, Gleditsch, Meth., p. 141; Rost., Mon., p. 193 (in part); Cke., Myx. Brit., p. 46 (in part); Sacc., Syll., vii., pt. I., p. 397.

Comatricha, Preuss. in Sturm's Deutschl. (in part); Rost., Mon., p. 197 (in part); Cke., Myx. Brit., p. 47 (in part); Sacc., Syll., vii., p. 394.

The genus Comatricha was distinguished according to Preuss by the globose or shortly elliptical sporangium from the species of Stemonitis, a character shown by Rostafinski to be untenable, hence the last-named author used characters supposed to be presented by the capillitium for the separation of the two genera. In Comatricha the meshes of the network are arcuate or curved, and not attached to the wall of the sporangium, by short branches, whereas in Stemonitis the threads are not arcuate at the surface, and the eapillitium is attached to the wall in numerous places by short branches. These characters, not being constant, and furthermore overlapping in the two genera, cannot be considered as of generic value, neither in my opinion would they be so even if constant.

Distrib. Scattered over temperate and tropical regions. Species 23.

A. Spores blackish brown in the mass.

§spores warted.

Stemonitis fusca, Rost. (figs. $155-157$ and $162-164$ ).

Denscly gregarious, springing from a vell-developed, broadly 
spreading hypothallus; sporangia cylindrical, obtuse or attenuated at the apex, wall thin, evanescent; blackish with metallic tints; stem slender, equal, shorter than the sporangium, blackish, shining; columella reaching nearly to apex of sporangium; capillitium dense, threads blackish, tapering, combined into a dense, irregular net, the peripheral meshes smaller or equal to the spores in diameter: spores in the mass black, with violet tinge, dingy violet by transmitted light, globose, varying from distinctly verrucose to almost smooth, size also variable, from $5-11 \mu$ diameter.

Stemonitis fusca, Rost., Mon., p. 193, fig. 40 ; Cke., Myx. Brit., p. 46, fig. 40 ; Sacc., Syll., n. 1362.

Exsicc.-Roum., Fung. Sel. Gall. (Rel. Moug.); Ellis, N. Amer. Fung., 1119; Fckl., Fung. Rhen., 1149; Holl, Schmidt, and Kunze, Deutschlands Schwamme, n. cix.; Cke., Fung. Brit., Ed. ii., n. 522; Fung. Cub. Wrightiani, n. 538; Roum., Fung. Gall., Cent. xiv. (number indistinct).

On rotten wood, \&c. Britain (Bournemouth, Kew, Ilfracombe, Epping; Bulmer, Yurks; Carlisle, Aboyne); Europe; N. America; Cuba ; Venezuela; Natal ; Maúritius; Himalayas; Ceylon; Victoria; Tasmania.

From 5-14 mm. high. The only large British species with a small meshed capillitium and spores blackish violet in the mass.

\section{(Rostafinski’s Synonyms.)}

Lycoperdon capite cylindracea, Rupp. Jenn., 304 (1718).

Clathroidastrum obscurum, Mich., t. 94, f. 1 (1729).

Embolus nigerrimus, Hall, t. i., f. 1 (1742).

Clathrus nudus. Linn., Fl. Suec., 1263 (1745).

Stemonitis I, Gled., Meth., 141 (1753).

Embolus, Hall, 2137, t. 48, f. 1 (1768).

Tubulifcra cremor, Fl. Dan., t. 659, f. 1 (1777).

Tremella typhina, Willd. Fl. Ber., 420 (1787).

Mucor arancosus, Jacq. Misc., t. 15 (1778).

Stemonitis fusca, Roth. Mag. Bot., p. 26 (1782); Ehr. Ber., f. 5 ; Grev., S. C. Fl., t. 170 ; Corda Ic., ii., f. 87 ; Eng. Fl., v., 317; Cooke, Hdbk., 1155, fig. 132, Fung Britt., ii., 522. 
Trichia nuda, With. Arr., iv., 477 (1792).

Stemonitis fasciculata, Pers., Syn., 187 (1801).

Stemonitis typhoides, Auct.

\section{Stemonitis maxima, Sz.}

Sporangia crowded, stipitate, springing from a well-developed hypothallus; sporangia cylindrical; wall blackish, reflecting metallic tints, evanescent; columella reaching almost to the apex of the sporangium; capillitium dense, branches often arcuate, sometimes more or less irregularly dilated, especially at the nodes, peripheral meshcs much larger than the diameter of the spores; mass of spores blackish brown; spores globose, very minutely verruculose, $5-10 \mu$ diameter; stem filiform, black, shining, shorter than the sporangium.

Stemonitis maxima, Schweinitz, Syn. Fung. Amer., n. 2349 (specimen from Schweinitz in Herb. Berk., Kew, n. 10835).

Stemonitis splendens, Rost., Mon., p. 195; Sacc., Syll., vii. 1, n. 1364. (Authentic specimen named by Rostafinski.)

On wood, \&c. Russia; Finland; France; Ceylon; Mauritius; Cuba; United States; Australia; Cape of Good Hope.

A fine large species, distinguished amongst the dark-spored species by the large peripheral meshes of the capillitium. Lumps of organic matter are sometimes met with in considerable quantities on the threads of the capillitium; $1.5-3 \mathrm{~cm}$. high.

\section{Stemonitis typhina, Mass.}

Gregarious, but not usually crowded, springing from a delicate hypothallus; sporangia cylindrical, obtuse at both ends, wall very thin, brownish, disappearing; columella reaching to the apex, capillitium dense, threads originating at numerous points from the columella, dingy brown, copiously branched and forming a dense, irregular network, thickest at the point of origin and tapering towards the periphery where they are very slender, and form a network of irregular pattern, with the meshes usually not larger than the diameter of the spores; stem erect, slender, cyliudrical, usually rather shorter than the sporangium, blackish; 
mass of spores brownish-black, lilac-brown by transmitted light, globose, very minutely asperate, $5-8 \mu$ diameter.

Rostafinski gives the following forms, but it is not unusual to meet with both in the same cluster.

a. Genuina.-Sporangium with stem $2 \frac{1}{2}-4 \mathrm{~mm}$. high.

B. Pumila.-Sporangium with stem $2 \mathrm{~mm}$. high.

Comatricha typhina, Rost., Mon., p. 198, figs. 46, 47; Cke., Myx. Brit., p. 47, figs. 46, 47; Sacc., Syll., vii., n. 1355.

On rotten wood. Britain (Lyndhurst, Kew, Scarboro', Carlisle, Aboyne, N. B.); Europe; U. States; Cuba; Ceylon; New Zealand.

From 4-7 mm. high. Closely allied to C. pulchella, but distinguished by the dark brown colour of the spores in the mass,

\section{(Rostafinski's Synonyms.)}

Clathroidastrum obscurum, Mich., t. 94, f. 2 (1729).

Mucor capitulo fusco, Scop., Fl. Carn., 66 (1760).

Mucor Stemonitis, Scop., Fl. Carn., 493 (1772); Schpf., t. 296.

Embolus lacteus, Jacq., Musc. 1, t. 6 (1778).

Clathrus nudus, Fl. Dan., t. 755 (1782).

Clathrus fertusus, Batsch, f. 176 (1753).

Stemonitis typhina, Roth. Fl. Germ., 1, 547 (1798); Pers.,

Obs., 1, 57.

Stemonitis filicina, Schrk., Fl. Bav., 1782 (1789).

Trichia typhoides, Bull., t. 477, f. 2 (1791).

Stemonitis typhoides, D. C., Fl. Fr., ii., 257 (1805); Cooke, Hdbk., n. 1157.

Stemonitis bicolor, Fries, Herb.

Stemonitis leucopoda, Fr. Gast., 16 (1817).

Stemonitis pumila, Corda Ic., v., p. 37 (1842).

\section{Stemonitis macrosperma, Mass.}

Sporangia naked, stipitate; stem continued into the sporangium as a-columella, reaching nearly to the apex, threads of capillitium passing from the columella to the wall and pro- 
ducing very much thinner branchlets, which are combined amongst themselves at all points to form a rather loose network, the peripheral meshes of the network formed of combined, arcuate threads, and slightly smaller than the rest, cspecially towards the base of the capillitium; spores $9-12 \mu$ diameter, pale violet, verruculose.

Stemonitis macrosperma, Racib., Myx. Crac., p. 8; Sacc., Syll., vii., 1, n. 1361.

Var. obovata. Racib., sporangia obovate, $0.5-0.75 \mathrm{~mm}$. broad. With the type.

Var. oblonga. Racib., sporangia oblong, $0.75-1 \mathrm{~mm}$. long, $0.3-0.5 \mathrm{~mm}$. broad. With the type.

Poland.

\section{Stemonitis Suksdorfii, Mass.}

Gregarious, stipitate, sporangia cylindrical, very obtuse at both ends, wall iridescent, evanescent; stem blackish-brown, shining, about equal in length to sporangium, tapering upwards, rather stout, becoming dilated at the base into a hypothallus; spores in the mass blackisst-purple. Columella rather thick, sub-equal, blackish, usically becoming abruptly divided into branches at some distance below the apcx of the sporangium; sometimes more or less flattened at the apex, and with a tendency to become discoid; capillitium exccedingly dense, dark, main branches originating from the columella; stout, tapering, branches arcuate, combined to form an irregular, smallmeshed network; spores bright lilac, minutely warted, 7-8 $\mu$ diameter.

Comatricha Sulsslorfii, Ellis and Everh.

On wood, bark, \&c. United States.

(Described from a portion of type specimen communicated by Wingate.)

From 5-6 mm. high.

Stemonitis affinis, Mass.

Sporangia cylindrical, obtuse, up to $2 \mathrm{~mm}$. high; stem from its shortness scurcely distinct: columella reaching almost to apex 
of the sporangium, then dividing into $2-5$ branches; threads of capillitium much more rigid at the base than in the ulterior, very loose network, nodes often triangular, ultimate branches arcuate, transversely joined, some free and excurrent; spores pale violet, warted, 5-6 $\mu$ diameter.

Comatricha affinis, Rost., Mon., p. 202 ; Sacc., Syll., vii., 1 n. 1359.

Germany.

Stemonitis confluens, Cke. and Ellis.

Forming compact tufts about $2 \mathrm{~mm}$. high, from 8-15; individuals spring from a firm, spreading, venulose hypothallus; stems usually simple and distinct, dark brown, wrinkled towards the base, about $5 \mathrm{~mm}$. high, then breaking up into from 2-4 main branches or columellas which anastomose laterally with those of other individuals forming an irregular plasmodiocarp, covered with a blackish-violet, evanescent, common cortex; mass of spores black with violet tinge; the main branches springing from the columellas form a dense network, threads arcuate, many of the meshes closed by a thin membrane; spores globose, dingy violet, minutely warted, $7-8 \mu$ diameter.

Stemonitis confluens, Cke. and Ellis, Grev., vol. v., p. 51.

- Comatricha confluens, C. and E., Myx., U. States, p. 396.

On oak bark. United States.

A very interesting species, and highly instructive in showing how the fundamental simple form becomes modified by confluence. The general mass of the plasmodiocarp is sometimes spherico-depressed, and even at others the columella of one individual of the colony remains simple and projects above the mass as a finger-like projection; in others all the individuals are more or less free at the tips. When the wall and spores are completely blown away, the resemblance of the capillitium to that of Reticularia is striking. 


\section{$\S \S$ Spores smooth.}

Stemonitis atra, Mass. (n. sp.).

Scattered; sporangia cylindric-ovate, black, slightly iridescent; stem twice as long as sporangium, thin, equal, dull, black, expanding at the base into a minute, circular hypothallus; mass of spores brown with a lilac tinge; columella as thick as the stem, equal, reaching to apex of sporangium; main branches scattered, remaining simple for a short distance then branching and forming a network, the meshes becoming smaller towards the periphery where they equal the spores in diameter; all the branches of the network of equal thickness, very stout, $35-4 \mu$ diameter; dark brown; spores globose, dingy lilac-brown, smooth, $10 \mu$ diameter.

On wood. New Zealand.

Remarkable in the scattered habit, $6-8 \mathrm{~mm}$. high. Readily distinguished by the very thick threads of the capillitium. The columella sometimes breaks up into branches a short distance below the apex of the sporangium.

\section{Stemonitis acuminata, Mass. (n. sp.).}

Gregarious, or often densely crowded on a well-developed, iridescent hypothallus; sporangia cylindrical, elongato-acuminate at the apex; wall blackish-purple, iridescent, disappearing; stem equal to or shorter than sporangium, filiform, slightly attenuated upwards; blackish, shining; mass of spores black with purple tinge; capillitium continuing to the apex of the sporangium, primary branches scattered, short, supporting a netroort of irregularly polygonal meshes which are large and everywhere of equal size, $40-50 \mu$ in diameter; spores globose, smooth, 13-14 $\mu$ diameter.

On rotten wood. Cape of Good Hope (Table Mountain).

Agreeing with Stemonitis Morgani in the large-meshed capillitium, but distinguished by the acuminate apex of the sporangium and the larger spores; $1.5 \mathrm{~cm}$. high. 
Stemonitis Bäuerlinii, Mass. (n. sp.).

Densely gregarious on a well-developed, firm hypothallus; sporangia elongato-fusiform, wall blackish, iridescent, very evanescent, mass of spores black with a violet tinge; stem erect, black, shining, slightly tapering from the base; columella extending to apex of sporangium; flexuous above; capillitium of lower half of sporangium of large, equal meshes which are peripheral only and supported on distant, thin, simple or rarely divided branches springing from the columella, the main branches become more and more numcrous, thicker, and irregular towards the apex of the sporangium, and often form irregular, flattened expansions; the branches forming the net are also much thicker, and the meshes irregular, and not all peripheral as towards the base of the sporangium; many of the branches of the network towards the apex with short free ends; spores globose, smooth, $5-6 \mu$ diameter.

On wood. New Guinea (Strickland River).

'From 1·5-2 cm. high. Distinguished by the capillitium being very scanty and the network being entirely peripheral below, becoming very dense towards the apex.

\section{Stemonitis laxa, Mass.}

Sporangia spherical, scarcely $5 \mathrm{~mm}$. diameter; stem rigid, black, not attaining to $1 \mathrm{~mm}$. in length; columella almost reaching to apex of sporangium, and then dividing into 2-3 branches; threads of the capillitium of equal width throughout, very rigid, forming a regular, lax network, ultimate branches arcuate, connected by transverse bands, some remaining free and furcately divided; spores smooth, lilac, $9-11 \mu$ diameter.

Comatricha laxa, Rost., Mon., p. 201 ; Sacc., Syll., vii., 1, no. 1358.

Germany.

\section{Stemonitis fluminensis, Speg.}

Hypothallus very thin, broadly effused, mucedinous, black, rather shining; stem erect, rather rigid, shining, black, $0.5-1$ 
mm. long, $0.7-0.6 \mathrm{~mm}$. thick; smooth when moist, rugulose when dry, sub-contorted, extended into the sporangium as a columella, not reaching to the apex; sporangium cylindrical, rarely sub-clavate, rounded at both ends, 0.8-1.2 $\mathrm{mm}$. long, 0.3-0.2 mm. thick, black, opaque, wall persistent for a long time; capillitium springing from the columella, forming a rather dense network, the superficial meshes equal to or twice the diameter of the spores, with uncinate free tips; spores globose or sub-elliptical, 5-8 $\mu$ diameter, perfectly smooth, smoky brown.

Stemonitis fluminensis, Speg., Fung. Arg., N. 261 ; Sacc., Syll., vii., 1, n. 1366.

On bark, moss, \&c. Brazil.

Stemonitis subcaespitosa, Mass.

Stems subcaespitose or locisely clustered, thickened at the base, about half the length of the sporangia, extending through the capillitium as a columella; peridia ovate-oblong, obtuse, fugacious; capillitium growing from the columella, reticulately connected and also forming a superficial net with coarse meshes, blackish; spores globose, even, (smooth?), blackish-brown, $.0004-00045$ in. in diameter.

Comatricha subcacspitosa, Peck, 43rd Report, New York State, Mus. Nat. Hist. (1890), p. 25, Pl. iii., figs. 6-9.

Decorticated wood of hemlock. Tsuga Canaulensis. Sandlake. July.

This species resembles Stcmonitis fusca in colour. In size it approaches Comatricha typhina. Its capillitium is variously connected, and appears to combine the reticulation of Comatricha and Stemonitis, but on account of the network not being wholly parallel to the walls of the peridium, it is placed in Comatricha. The plants are mostly conuected in small groups or loose clusters of two to ten individuals. Its coarser meshes and larger spores distinguish it from Comatricha typhina. (Peck, l. c.).

\section{Stemonitis aequalis, Mass.}

Gregarious or loosely clustered, about three lines high, arising from a thin hypothallus; sporangia cylindrical, obtuse, fugacious, 
wholly falling away; capillitium brown or blackish-brown, forming an intricate network; stem slender, smooth, black, penetrating the capillitium as a columella, and extending nearly or quite to the apex, the free portion about equal in length to one-half the altitude of the entire plant; spores globose, smooth, violet-black, $\cdot 0003^{\prime}-00035^{\prime}$ in diameter ( = about 8-9 $\mu$ ).

Comatricha aequalis, Peck, 31st Report of State Mus., N. Y., p. 42 ; Sacc., Syll., n. 1360.

Decaying wood. Catskill Mountains. Sept.

In colour this species is almost exactly like Stcmonitis fusca, from which its more lax habit, proportionally longer stem and different capillitium separate it.' The larger size, both of the plant itself and of the spores, will separate it from Comatricha typhina. The length of the stem and of the capillitium are nearly equal, hence the specific name. (Peck.)

\section{Stemonitis tenerrima, B. and C.}

Gregarious; sporangia cylindrical, base and apex very obtuse, wall thin, blackish-purple, iridescent, evanescent; stem about equal in length to sporangium, filiform, blackish, sub-equal; columella reaching nearly or quite to apex of sporangium; primary branches short, breaking up into a network, the meshes becoming smaller towards the periphery where they equal the spores in diameter, the threads taper towards the periphery; spores in the mass black with violet tinge, globose, smooth, 13-14 $\mu$ diameter.

Stemonitis tenerrima, Berk. and Curt., Grev., vol. ii., p. 69.

(Type in Herb. Berk., Kew, n. 10831.)

On wood. Lower Carolina.

Distinguished by the small size $3.5-4 \mathrm{~mm}$., cylindrical sporangium, and the large, smooth spores.

Whether the present species is identical with "Stemonitis tenerrima Curtis in Sill., Journ., 1. c., p. 349 (1848)," as quoted by Rostafinski, Mon., Append., p. 27, I have no means of determining. 


\section{Stemonitis Friesiana, De Bary.}

Scattered or gregarious; sporangia globose on shortly elliptical, wall very thin, disappearing, whitish with a silvery sheen or purple black; stem blach, shining, elongated, tapering upwards, expanding at the base into a small, circular, irregularly ribbed or latticed hypothallus; columella reaching about two-thirds the height of the sporangium, then breaking up into several branches, threads of capillitium dark brown, arcuate, forming a dense net; spores in the mass blackish, violet-brown by transmitted light, globose, smooth, 8-10 $\mu$ diameter.

Stemonitis Friesiana, De Bary, in Rab. F. Eng., n. 568.

Comatricha Friesiana, Rost., Mon., p. 199, figs. 51 and 56 ; Cke., Myx. Brit., p. 48, figs. 51 and 56 ; Sacc., Syll., vii., 1356.

Exsicc.-Fuckel, Fung. Rhın., n. 1446 (as Stemonitis ovata).

On wood, branches, leaves, \&c.

Britain (Lyndhurst, Kew, Hereford, York, Carlisle, Aboyne, N. B.) ; Europe; U. States; Ceylon; Tasmania.

From 3-5 $\mathrm{mm}$. high. The threals of the capillitium are of nearly equal thickness throughout, and sometimes studded with amorphous lumps of organic matter. Distinguished by the long, tapering stem, and small globose, or shortly ovate sporangium.

\section{(Rostafinski's Synonyms.)}

Mucor cmbolus, Linn. Sp., 1185 (1753).

Lycogala, Hall, 2146 ? (1768).

Stemonitis reticulata, Trent, p. 223? (1797).

Stemonitis nigr'a, Pers., Gmel. Sys., 1467 (1791).

Stemonitis atrofusea, Pers., Disp., 11 (1797).

Stemonitis atrofusca, $\beta$ nigra, Pers., Disp., 54 (1797).

Stemonitis ovata, Pers., Syn., 189 (1801); Berk., Eng. Fl., v., p. 317 ; Cooke, Hdbk., no. 1158.

Trichia mucoriformis, Schum., Saell, 1469 (1803).

Stemonitis violacea, Schum., Saell., 1491 (1803).

Stemonitis nigra, Schum., Saell., 1493 (1803).

Stemonitis globose, Schum., Sacll., 1494 (1803). 
Trichia alba, Sow., t. 259 (1818).

Stemonitis obtusata, Fr. Sym. Gast., 17 (1818); Eng. Fl., v.,

p. 317 ; Cooke, Hdbk., no. 1159.

Comatricha obtusata, Preuss., Sturm. (1851).

Comatricha alba, Preuss. in Sturm (1851).

Stemonitis Friesiana, De Bary (1870); Rabh., Fung. Eur., no. 568.

\section{$\S \S \S$ Spores reticulated.}

\section{Stemonitis longa, Mass.}

Sporangia gregarious, slender, cylindrical, straight, or usually flexuons, very long; wall evanescent; stem filiform, slender, rather short, blackish; columella, capillitium, and mass of spores brownish-violet; columella extending nearly to apex of sporangium, tapering upwards; capillitium springing from the columélla at numerous points throughout its length, main branches soon branching, axils usually rounded, often occupied for some distance by a thin membrane, sometimes connected laterally, branches towards the periphery much branched in a penicillate manner, tips free; spores globose, epispore very minutely reticulated, 7-8 $\mu$ diameter.

Comatricha longa, Peck, 43rd Report of New York State Mus., p. 24, pl. 3, f. 1-5.

On wood,' bark, \&c. United States.

Fasciculate, capillitium often curved or twisted after the wall has disappeared, $3-6 \mathrm{~cm}$. long.

Stemonitis dictyospora, Rost. (fig. 112).

Sporangia gregarious, cylindrical, both ends obtuse, wall silvery, soon disappearing, stem shorter than sporangium, rather thick, equal, black, springing from a well-developed hypothallus; columella reaching nearly to apex of sporangium, capillitium dense, threads like the columella blackish, combined to form a network having the peripheral meshes not larger than the diameter of the spores; spores in the mass blackish-violet, globose, epispore with thin ridges forming a polygonal network, 12-15 $\mu$ diameter. 
Stemonitis dictyospora, Rost., Mon., p. 195 ; Sacc., Syll., vii., 1, 1363.

On palm leaves. Venezuela; Amazon Valley; United States. The type specimen on which Rostafinski founded the species is in the Berkeley herbarium, Kew, and had evidently been considered as distinct as the MS. name of "S. trechispora, B. and C.," is on the paper in Berkeley's writing. It seems a pity that Rostafinski could not accept this name. Distinguished at once by the silvery white sporangial wall, very small peripheral meshes of the capillitium, and reticulated spores.

B. Spores bronon or ferruginons in the mass.

$\S$ Spories smooth.

Stemonitis Carlylei, Mass. (n. sp.) (figs. 158, 159).

Growing in small scattered tufts, sporangia cylindrical, apex obtuse, wall very thin, evanescent except the apical portion, which remains like a cap, dark, with purple or dark blue tints; stcm short, dark, expanding into a tough, brown, common hypothallus; mass of spores dull orange-browon; columella attenuated upwards, disappearing just below the apex; capillitium dense, originating in numerous stout branches from the columella, which soon break up into thinner branches that anastomose to form a dense, irregular net, threads arcuate, peripheral meshes large, at least twice the diameter of the spores, and bearing numerons free tips which are at first attached to the wall, brown, becoming paler towards the periphery; spores globose, pale, clear orange-browon, smooth, $11-15 \mu$ diameter.

On wood. Carlisle.

Growing in small scattered tufts of from 8-14 plants, $3.5-4 \mathrm{~mm}$. high, the sporangia are cylindrical with abruptly rounded ends, or rarely slightly attenuated below, and passing into the stem, which is not usually a quarter the length of the sporangium. At once distinguished from Stcmonitis fermuginca, the remaining bright-spored species by the large peripheral meshes of the capillitium, with numerous free tips, and the 
larger spores. The spores sometimes show indistinct indications of warting under 1200 diameters.

Stemonitis ferruginea, Rost. (figs. 160, 161).

Densely gregarious, on a well-developed hypothallus; sporangium cylindrical, obtuse, wall thin, dark brown, evanescent; stem slender, blackish, equal to or shorter than sporangium; columella reaching to the apex of the sporangium, blackish; capillitium dense, threads dark brown, tapering, combined to form an irregular network, the peripheral meshes about equalling the spores in diameter; spores in the mass bright brown, pale brown by transmitted light, globose, smooth, 6-9 $\mu$ diameter.

Stemonitis ferruginea, Rost., Mon., p. 196, figs. 31-39, 41-44, and 50; Cke., Myx. Brit., p. 47, figs. 31-39, 41-44, and 50; Sacc., Syll., vii., n. 1365.

Éxsicc.-Rav., Fung. Car., 75 (typical); Rav., Fung. Amer., 788.

On rotten wood, \&c. Britain (Lyndhurst, Highgate, Scarboro', Carlisle, Linlithgow); Europe; United States; Mexico; S. Domingo; Cuba; Rangoon; Ceylon; Queensland; New Zealand.

Usually densely gregarious, $1-1 \cdot 5 \mathrm{~cm}$. high. Readily distinguished by the small peripheral meshes of the capillitium and the bright brown colour of the spores in the mass.

(Rostafinski's Synonyms.)

Stemonitis typhina, Willd., Ber., 408 (1787).

Clathrus nudus, Bolt., t.' 93, f. 1 (1789).

Triehia axifera, Bull., t. 447, f. 1 (1791).

Stemonitis fasculata, Pers., Syn., 187 (1801).

Stemonitis violacea, Schum., Saell., 1491 (1803).

Stemonitis fasciculata, DC., Fl. Fr., ii., 256 (1805).

Stemonitis ferruginea, Ehr., Syl. Ber., f. vi. a b (1818); Cooke, Hdbk., No. 1156.

Stemonitis decipiens, Nees. Nov. Act. Leop., xvi. 95 (1821).

Stemonitis heterospora, Oudem. Ned. Kr. Arch., i., 167 (1S72). 
Stemonitis Morgani, Peck.

Sporangia crowded, stipitate, springing from a well-developed hypothallus; cylindrical, wall evanescent; stem much shorter than sporangium, black, shining; mass of spores brmon with a formuginous tinge; columella evanescent just below the apex of the sporangium; threads of capillitium forming the network brown, sub-cqual, about $3 \mu$ thick, meshes large, and about equal in size at every part, spores globose smooth, $6-7 \mu$ diameter.

Stcmonitis Morgani, Peck, Bot. Gaz., vol. vo, p. 33; 34th Report State Mus., N. Y., p. 43; Sacc., Syll., vii., 1, n. 1368.

Exsice.-Ellis and Everhart, N. Amer. Fung., Ser. II., n. 2088. On bark, wood, \&c. United States.

Agreeing in the large meshed capillitiun with $S$. Carlylei and S. maxima; differing from the former in the much smaller spores, and from the latter in the brown or sub-ferruginous colour of the spores in the mass.

\section{$\S \S$ Spores warted.}

\section{Stemonitis pulchella, Bab.}

- Scattered or gregarious, springing from a delicate hypothallus; sporangic cylindrical or cylindrical-ovate, apex obtuse, base usually slightly umbilicate, wall delicate, silvery or dark; stem rather stout, blackish, sub-equal or slightly tapering upwards, expanded at the base, shorter than sporangium; columella reaching nearly to the apex of the sporangium; capillitium dense, threads tapering, arcuate, brown, forming a dense, irregular net with the periphcral meshes not larger than the diameter of the spores; spores in the mass clear ferrnginons, pale brown by transnitted light, globose, minutcly warted, 6-8 $\mu$ diameter.

Stemonitis melchella, Babington, Linn. Soc. Trans., 1839; Berk., Ann. Nat. Hist., 1841, p. 431, t. 12, f. 11; Cke., Hdbk., n. 1160.

Comatricha melehclla, Rost., Mon., Suppl., p. 27 ; Cke., Brit. Myx., p. 49 ; Sacc., Syll., vii., pt. I., n. 1357. 
(Type in Herb. Berk., Kew, n. 10\$41.)

On twigs, herbaceous stems, ferns, \&c.

Britain (Bardon); Germany.

The peridium is sometimes almost white with a silvery sheen, at others brown. From $4-6 \mu$ high. Much shorter and not so densely crowded as $S$. ferruginea. Quite distinct from $S$. pulcherrima, B. and C.

\section{(Rostafinski's Synonyms.)}

Stemonitis pulchella, Bab., Trans. Linn. Soc., cfr. Berk., A. and M. (1841), p. 431, t. 12, f. 11 (1839).

Stemonitis tenerrima, Curtis, Sill. Journ., l. c., p. 349 (1848).

Stemonitis tenerrima, B. and C., Grev., n. 373 (1873).

\section{Stemonitis herbatica, Peck.}

Sporangia densely gregarious, stipitate, springing from a thin hypothallus, sub-cylindrical, wall evanescent; stem usually shorter than sporangium, thin, blackish; spores in the mass brown; columella reaching nearly to apex of sporangium; capillitium dense, periphercl meshes not larger than diameter of spores, threads sometimes furnished with a few short, free ends; spores globose, very minutely warted, $8-9 \mu$ diameter.

Stemonitis herbatica, Peck, 26th Report State Mus., N. Y., p. 75 ; Sacc., Syll., vii., 1, no. 1367.

\section{(Authentic specimen from author.)}

On living leaves, stems, \&c. United States.

Often in scattered, small, densely crowded clusters, $5-8 \mathrm{~mm}$. high. Allied to S. ferruginea in the colour of the spore-mass, and in the small peripheral meshes of the capillitium, differing in the very minutely warted spores.

\section{Stemonitis tubulina, A. and S.}

Aethalium at first white, soft, $1 \frac{1}{2}-2$ in. broad, 4-6 lines high, orbicular, rarely sub-oblong, basal membrane stout, silvery, pellucid, iridescent, easily removable from the substratum; surface very smooth, shining, with hemispherical warts above, 
regularly arranged and corresponding to the apices of the component sporangia; columella (stylidia) brown, slender, capillary, aggregated, but for the most part individually free; capillitium loosely interwoven into a common mass; mass of spores brown.

Stemonitis Tubulina, Alb. and Schu. Consp., p. 102.

On decorticated pines. Germany.

From the description given by Albertini and Schweinitz, I have very little doubt but that the organism they had in view was Siphoptychium Casparyi, Rost.

In Saccardo's Sylloge, vii., p. 399, the following synonyms and remarks are given.

Stemonitis fusca, var. $\beta$ Fr. Syst. Myc., iii.; Amaurochacte speciosa, Zukal, Eni. Pilze Myx. Bact., p. 5, t. 15, f. 3.

According to Raciborski, Hedw. 1887, p. 3, the above species is neither a species of Stemonitis nor Amaurochacte, but a new genus described under the name of Jundzillia, Racib.

\section{Siphoptychium, Rost.}

Sporangia sessile, densely crowded, springing from a welldeveloped hypothallus, cylindrical, or prismatic from mutual pressure, the whole forming a naked aethalium; wall of sporangium single, thin; columella central, springing from the hypothallus and reaching to the apex of the sporangium, tubes of capillitium rather scanty, radiating from the columella to the wall of the sporangium.

Siphoptychium, Rost., Mon., App., p. 32; Cke., Myx. Brit., p. 83 ; Sacc., Syll., vol. vii., part I., p. 417.

The general habit and appearance of some species of Tubulina from which the present genus differs in the presence of a central columella and capillitium; yet the general structure and arrangement of the sporangia and the spore sculpture of the only known species is so thoroughly that of Tululine cylindrica, that it seems very probable that the present genus is an evolution from the last-named species, or some close ally, the columella and radiating tubes being derived from modified sporangial walls. 
Siphoptychium Casparyi, Rost. (fig. 111.)

Sporangia crowded on a well-developed hypothallus, elongated, cylindrical or prismatic from mutual pressure, apices slightly convex, wall thin, brownish, iridescent; mass of spores umber; columella thin, reaching nearly or quite to apex of sporangium, tubes of capillitium simple, rarely branched, springing from the columella and extending to wall of sporangium; spores globose, with a minutely raised network, 7-9 $\mu$ diameter.

Siphoptychium Casparyi, Rost., Mon., Append., p. 32, fig. 245 ; Sacc., Syll., vii., 1, n. 1423.

Exsicc.-Ellis and Everh., N. Amer. Fung., n. 2092.

On wood, \&c. United States.

Sporangia up to $5 \mathrm{~cm}$. high, and about $5 \mathrm{~mm}$. diameter of equal height, and densely packed side by side, forming cakelike aethalia, stated in letter from Dr. Rex, of Philadelphia, who has collected this species in abundance, to average from three to five inches in diameter; but one aethalium collected in the Adirondack Mountains, N. Y., measured one foot and a lialf in length by one foot in width, with various prolongations besides.

Amaurochaete, Rost.

Aethalium consisting of numerous elongated, naked sporangia, compacted together in several layers, and enclosed in a common delicate cortex; the capillitium consists of several columellalike, erect tubes springing from the base of the aethalium, and anastomosing amongst themselves form tree-like branches, which along with the secondary branches combine to form an irregular network; angles of the larger forks of the capillitium connected for some distance by a thin web-like membrane.

Amaurochaete, Rost., Mon., p. 210; Cke., Myx. Brit., p. 52 ; Sacc., Syll., p. 401.

Closely related to if indeed distinct from Reticularia.

Distrib. Europe; United States. Species 1.

Amaurochaete atra, Rost.

Aethalium variable in size, pulvinate, covered with a thin, 
fragile, blackish cortex; capillitium denše, forming an irregular network, the two branches forming the angles of the larger dichotomies connected by a membrane; spores brownish-violet, globose, minutely warted, $14-17 \mu$ diameter.

Amaurochacte atra, Rost., Mon., p. 210, fig. 67; Cke., Myx. Brit., p. 52, f. 67; Sacc., Syll., vii., no. 1375.

On wood and bark, especially of pines. Britain (Ascot, Lyndhurst, Leicester, Somerset, Aboyne, N. B.); Germany; France; Sweden; United States.

Varying from $1-3$ in. or more across.

In the typical form the sporangia are very irregular and have nearly lost their individuality, whereas in other specimens the whole structure suggests the idea of a number of confluent individuals of a sessile Stcmonitis.

Brefeldita, Rost.

Aethalium composed of numerous naked, elongated, closelypacked sporangia, arranged in several strata; columellas of the various sporangia coalescing to form tree-like branchings, branches of the capillitium meeting at the boundary of the sporangia and coalescing by the formation of polycellular vesicles.

Brefeldia, Rost., Mon., p. 212 ; Cke., Myx. Brit., p. 53 ; Sace., Syll., vii., p. 402 ; Raunk., Myx. Dan., p. 96.

Like Reticularia, the one species constituting the present genus is only known in the aethalioid form, and the component sporangia are much contorted. The principal feature of the genus is the presence of numerous very peculiar structures met with scattered at intervals in the threads of the capillitium. These bodies usually consist of eight cell-like vesicles more or less quadrate in outline, measuring $8-15 \mu$ in diameter, and arranged in a quadrate manner, the capillitium threads are attached to the four cells forming the two ends of the cluster of vesicles by short branches, usually four in number, one being attached to each vesicle. Rostafinski says that these 
bodies are situated at the points where adjacent sporangia meet.

Distrit. Europe. Species 1.

Brefeldia maxima, Rost. (figs. 254-256).

Aethalium large, pulvinate, surface blackish with purple or olive tints, rough with irregular wart-like nodules, seated on a firm, silvery-looking hypothallus; capillitium dense, threads irregularly anastomosing, dark coloured, with numerous intercalary clusters of vesicles; spores in the mass blackish with a purple tinge, globose, minutely warted, $13-17 \mu$ diameter.

Brefeldia maxima, Rost., Mon., p. 213, figs. 60, 65, 66, 69, 70 , Cke., Myx. Brit., p. 53, figs. 60, 65, 66, 69, 70 ; Sacc., Syll., vii., no. 1377 ; Raunk., Myx. Dan., p. 96, t. 5, f. 13.

Licea perreptans, Berk., Gard. Chron., 1848, p. 451.

Exxice.-Cke., Fung. Brit., Ed. II., n. 518.

On fallen trunks, \&c. Britain (Rolleston, Kew); Germany.

Forming large pulvinate patches of irregular form varying fiom $1-6$ inches across.

\section{(Rostafinski's Synonyms.)}

Lycoperdon epidendrum, Sow., 400, f. 2, 3 (1809).

Dermodium inquinans, Fr. Gast., 9 (1817).

Reticularia maxima, Fr. S. M., iii., 85 (1829); Eng. Fl., v., 308 ; Cooke, Hdbk., No. 1097; Fungi Britt., ii., 518.

Iycoperdon echiniformis, Sow., t. 400, f. 1.

Licea perreptans, Berk., Gard. Chron. (1848), 451 ; Ann. Nat. Hist., No. 392; Cooke, Hdbk., No. 1196.

\section{Rostafinskia, Speg.}

Sporangia flexuous, intricately combined to form aethalia of varying magnitude, seated on a floccoso-papyraceous hypothallus; columellas absent; capillitium well-developed, not furnịshed with granules of lime, persistent, naked; spores globose or irregular, coloured, present only in the central stratum of the aethalium. 
Rostafinskia, Speg., Fung. Arg., Pug. İII., p. 27 ; Sacc., Syll., vii., 1, p. 403 (not of Raciborski).

I am not acquainted with the single species constituting the present genus which appears to be exceptional in the septate tubes of the capillitium, \&c.

Distrib. Argentine Republic. Species I.

\section{Rostafinskia australis, Speg.}

Aethalia variable in form, thickly pulvinate-effused; ecorticate, surface softly velvety-tomentose, at first with a longish cottony tomentum, then breaking up into powdery filaments, purpleviolet or bright reddish-violet; capillitium tubes of the intermediate stratum cylindrical, $3-4 \mu$ thick, branched, not septate, everywhere rough with minute warts, hyaline or tinged violet, tubes of inferior sterile stratum cylindrical septate, nodulosely branched, 5-6 $\mu$ thick, smooth, brownish; spores globose, ovoid or irregular, filled with granular protoplasm, smooth, bright lilac, $8-10 \times 5-6 \mu$.

Rostafinslia australis, Speg., Fung. Arg., Pug. III., n. 59; Sacc., Syll., vii., 1, n. 1381.

On rotten trunks, sawdust, \&c. Everywhere very common.

Argentine Republic.

Reticularia, Bull.

$\Lambda$ ethalia composed of numerous elongated, naked sporangia, arranged in strata and covered with a thin, common cortex; capillitium consisting of several columella-like, slender, thinwalled tubes, that give off several lateral branches which anastomose to form an irregular network.

lieticularia, Bulliard, Hist. Champ., Rost., Mon., p. 240; Cke., Myx. Brit., p. 60; Sacc., Syll., vii., p. 418.

In the present genus numerous naked, elongated sporangia, arranged in a few superposed layers or strata, are covered with an external cortex. Each sporangium has its own long columella, which gives off lateral branches that anastomose to form an irregular network, the branches of contiguous sporangia 'also 
anastomose. The structure of the entire body may be compared with the dense clusters of sporangia in stemonitis, differing in the irregularity of the sporangia and absence of sporangial walls. Enteridium Rozeanum bears a close resemblance to the present genus, but there the capillitium is formed from the walls of the component sporangia. Several exotic species placed by Berkeley in Reticularia belong to the genus Chromosporium.

Distrib. Europe and N. America. Species 3.

Reticularia lycoperdon, Rost. (figs. 311, 312).

Aethalium large, pulvinate, completely surrounded by a delicate cortex which varies from dull umber, through reddishbrown, to pale grey with a silvery lustre; sometimes rough with irregular, yellowish, minute warts; threads of the capillitium springing from the base, consisting of erect, columella-like portions with slender, anastomosing branches; spores in the mass varying from umber to chestnut-colour, globose, about onehalf the surface of the spore covered with a regular network of raised lines, the remainder smooth, $7-9 \mu$ diameter.

Reticularia lycoperdon, Rost., Mon., p. 240, figs. 3, 4, 6, 13 ; Cke., Myx. Brit., p. 60, figs. 3, 4, 6, 13; Sacc., Syll., vii., n. 1424.

Exsice.-Fuckel, Fung. Rhen., n. 2583.

On wood, bark, \&c. Britain (Bristol, Kew, Ecclesfield, Scarboro', Carlisle, Coed Coch, Linlithgow); Europe; United States.

Forming lumps varying from $1-3$ inches across, more or less circular or elongated, sometimes compressed, at others pulvinate, and 1 in. or more high. Care must be taken not to confound small specimens of the present species with Lycogala epidendrum, which differs in the thick capillitium threads with ornamented walls.

(Rostafinski's Synonyms.)

Lycogala griseum major, Mich., t. 95, f. 1 (1729).

Lycoperdon fuscum, Huds. Fl. Aug., 645 (1778).

Mucor lycogalus, Bott., t. 133, f. 2 (1789).

Reticularia lycoperdon, Bull., t. 446, f. 4, t. 476, f. 1-3 (1791). 
Lycogala argentea, Pers., Disp., 7 (1797).

Lycogala turbinatum, Pers., Syn., 157 (1801),

Strongylium fuliginoides, Ditm., t. 2, f. 1 (1809).

Fuligo lycoperdon, Schum., Saell., 1409 (1803).

Reticularia argentea, Poir., Ency., vi., 20 (1806).

Reticularia umbrina, Fr. S. M., iii., 87 (1829); Corda, Ic., vi., f. 36 ; Eng. Fl., v., 308; Cooke, Hdbk., No. 1100.

\section{Sub-sect. Ir. Lamprodermae.}

\section{LAMPRODERMa, Rost.}

Sporangia globose or broadly obovate, usually stipitate, stem continuous within the sporangium as a columella; threads of the capillitium originating from the apex only of the columella, primary branches either remaining simple for some distance or branching irregularly from the base, the branches combining to form an irregular network; wall of sporangium usually iridescent, soon disappearing.

Lumproderma, Rost., Mon., p. 202 ; Cke., Brit. Myx., p. 49; Sace., Syll., vii., 1, p. 390 ; Zopf, p. 156.

Closely allied to Diachace and Stemonitis, but differing from both in having the threads of the capillitium originating from the apex of the columella only.

Distrit. Europe; United States; Ceylon; Australia; New Zealand. Species 18.

\section{A. Spores smooth.}

Lamproderma violaceum, Rost. (figs. 152-154).

Gregarious on a strongly-developed hypothallus; sporangia sub-globose, convex above, flattened or slightly umbilicate bclow; wall thin, blackish, with a dark violet lustre; stem elongated, black, thick at the base, attenuatcd upvards; columella about half the height of the sporangium, filled with large colourlcss cells; branches of capillitium almost colourless, springing from the apex and sides of the columclla, irregularly branched and com- 
bined into a network; spores violet, globose, smooth, $9-12 \mu$ diameter.

Lamproderma violacea, Rost., Mon., p. 204, fig. 64; Cke., Brit. Myx., p. 50, f. 64; Sacc., Syll., vii., no. 1394.

On wood, moss, \&c. Britain (Shrewsbury, Castle Howard, Yorks); United States.

A very distinct and beautiful species, characterized by having the sporangium flattened or umbilicate below, and the almost colourless capillitium springing from every part of the columella. From 2-3 mm. high.

\section{(Rostafinski's Synonym.)}

Stemonitis violacea, Fr. S. M., iii., 16z (1829); B. and Br., Ann. Nat. Hist., 387; Cke., Hdbk., n. 1162.

Lamproderma irideum, Mass. (figs. 149-151).

Scattered; sporangia globose, wall thin, with steel-blue, green, or coppery metallic tints; stem elongated, blackish-brown, tapering upwards, expanded at the base into a small, circular hypothallus; columella cylindrical, about one-third the height of the sporangium, giving origin at the apex to several thick, ascending branches, which remain simple throughout the greater portion of their length, towards the tips repeatedly bifurcating, rarely anastomosing laterally, violet-brown, not paler at the tips; spores globose, violet-brown, smooth, $11-15 \mu$ diameter.

Lamproderma arcyrioides, Var. iridea, Cke., Myx. Brit., p. 50, figs. 246-249; Sacc., Syll., vii., n. 1353.

Exsicc. Cke., Fung. Brit., Ser. I., 523 (as Stemonitis arcyrioides); Cke., Fung. Brit., Ser. II., 523 (as Lamproderma arcyrioides).

\section{(Type in Herb., Kew.)}

On dead leaves, moss, \&c. Britain (Hampstead).

Distinguished by the scattered habit, smooth spores, and in the primary branches of the capillitium remaining unbranched except at the tips.

Lamproderma suboeneum, Mass.

Scattered; sporangia globose, small, wall thin, brown, with a 
bright coppery tinge, basal portion often remaining as a frill round the stem; stem elongated, tapering upwards, expanding at the base into a minute, circular hypothallus, brown; columella cylindrical, not more than one quarter the height of the sporangium, producing at the apex several primary branches, which are at once divided into numerous arcuate branches of equal thickness that combine to form a dense nct, threads brown, often studded with organic lumps; spores lilac-brown, globose, smooth, $14-16 \mu$ diameter.

Stemonitis physarioides, A. and S., Var. suboeneus, Berk., in Herb., n. 10842.

On slender twigs, moss, \&c. Britain (Bulmer, Yorks); United States.

Remarkable in the capillitium consisting entirely of equal, rather stout, arcuate threads combined into a network of small, sub-equal meshes. From $2.5-3 \mathrm{~mm}$. high, sporangium rarely attaining to $5 \mathrm{~mm}$. diameter, constantly the colour of new copper.

Lamproderma leucosporum, Rost.

Sporangia spherical, about $55 \mathrm{~mm}$. diameter, with various metallic tints; stem black, shining, subulate, thin, passing into the sporangium as an exactly cylindrical, truncate columella; throuls of the capillitium from the base variously branchcd and combincd to form a compact network, blackish when the spores are blown away; spores pale violet, $8-9 \mu$ diameter, smooth.

Lamproderma leucospomum, Rost., Mon., App., 26 ; Sacc., Syll., vii., 1, n. 1350 .

Lamproderma nigrescens, Rost., Mon., p. 205 (in part).

Germany.

\section{Lamproderma arcyrionema, Rost.}

Sporangia spherical, very small, with a silvcry metallic lustre, stipitate, stem straight, subulate, black, shining, dilated into a very thin, blackish-purple hypothallus, and passing into the sporangium as a very slender, cylindrical, truncate columella; branches of the capillitium everywhere of uniform thickness, 
divided from the base, arcuate, variously interlaced, and combined to form a dense net without free branches; spores pale violet, smooth, $6-7 \mu$ diameter.

Lamproderma arcyrionema, Rost., Mon., p. 208; Sacc., Syll., vii., 1, n. 1352.

Poland.

Judging from the description, the present species appears to approach very closely such species as Stemonitis Friesiana.

B. Spores warted or echinulate.

Lamproderma echinulatum, Rost.

Sporangia globose, dark steel-blue or blackish, iridescent; stem thick at the base, becoming attenuated upwards, sometimes'sub-cylindrical, black, filled with large cells that become smaller upvards; columella thick, filled with cells like the stem, about one-third the height of the sporangium, sometimes clavate; capillitium dense, originating from apex of columella and at once forming an irregular network without the usual undivided primary branches, tubes pale, irregular, arcuate, often flattened and triangular at the nodes; spores globose, dingypurple, coarsely echinulate, $15-22 \mu$ diameter.

Lamproderma echinulatum, Rost., Mon., Append., p. 25 ; Sacc., Syll., vii., 1, n. 1344.

Stemonitis echinulata, Berk., Fl. Tasm., p. 268.

(Type in Herb. Berk., Kew.)

Amongst moss. Tasmania.

Gregarious, springing from a hypothallus, 3-4 mm. high, Departing from the usual type of Lamproderma in having every part of the capillitium combined to form a network with arcuate branches. Differs from Comatricha in the capillitium originating from apex of thick columella only. Remarkable in having the stem and columella filled with large cells.

Lamproderma Listeri, Mass. (n. sp.) (figs. 202, 203).

Sporangia globose, dark-purple or blackish, iridescent, lower portion sometimes remaining as a frill round the stem; colu- 
mella slender, about one-third the height of the sporangium, capillitium ratber dense, the main branches springing from the apex of the columella which is sometimes expanded in a discoid manner, branches stout, simple for half their length, then two or three times dichotomous, axils acute, secondary branches straight, sometimes anastomosing laterally, tips colourless, the other portions blackish; sterie elongated, straight or sub-flexuous, conical, smooth, blackish-brown, filled with amorphous organic matter, springing from a hypothallus; spores globose, dingy purple, coarscly spinulose, 15-17 $\mu$ diameter.

Scotland (Moffat); Tasmania; N. Zealand.

On moss, wood, \&c.; gregarious, $2 \mathrm{~mm}$. high. A very fine species, remarkable for the elongated stem becoming usually much incrassated downwards, and in the apex of the columella being in some specimens expanded into a disc from the margin of which the primary branches of the capillitium originate. Both these features are characteristic of the genus Encrthenema, and the present specics forms a connecting link between the last-named genus and Lamproderma. Agreeing with L. echinulata in the large, spinulose spores; differing in the long, straight branches of the capillitium, and the stem being filled with amorphous lumps of organic matter.

\section{Lamproderma Ellisiana, Cooke.}

Sporangia globose, stipitate, minutely rugulose, blackishpurple, rather dull; columella short; capillitium originating from apex of columella, threads blackish-purple, very slender, cqual throughont, repeatedly forking from the base, angles very acute; stem coloured like the sporangium and twice as long, slender above, becoming very thick downwards, and expanding into a small, circular, brown hypothallus; spores in clustcrs of $5-7$; when the spores break up the clusters are sub-angular but soon become globose when free, pale lilac, minutely warted, $15-16 \mu$ diameter.

Lamproderma Ellisiana, Cke., Myx., U. States, p. 397. Badhamia penetralis, Cke. and Ellis, Grev., vol. v., p. 49. 
(Type in Herb., Kew.)

About $1 \mathrm{~mm}$. high; scattered. "On pine boards not much decayed, white at first." (Ellis.)

\section{United States.}

The clustered spores probably suggested the genus Badhamia, but the plant is a true Lamproderma, and quite distinct from a small species of Comatricha, with which it is mixed.

Ellis appears to have confused the true Lamproderma of Cooke with the Comatricha in the N. A. F., Ser. II.

Lamproderma robusta, Ellis and Everh.

Sporangia globose or slightly contracted below, stipitate, blackish-purple, dull; when in perfect condition covered with a very delicate bloom, lower portion usually remaining like a frill : round the stem; columella short, thick, wrinkled; capillitium very dense, springing from apex of columella, the main branches 3-5 $\mu$ thick, simple for a very short distance, then branching and anastomosing to form a small-meshed, very irregular dense network; threads tapering from the base, mostly flattened, angles often rounded, with scattered interstitial swellings, brownish-purple at the base, becoming paler upwards, attached. at numerous points to sporangial wall;: stem equal in length to sporangium or a little longer, blackish, smooth, equal, springing from a hypothallus; spores globose, dirty brownish-purple, minutely warted, $9-10 \mu$ diameter.

Lamproderma robusta, Ellis and Everhart.

(Described from portion of type communicated by $\mathrm{Mr}$. Wingate.)

On wood. United States.

A very distinct and beautiful species, gregarious, springing from a common hypothallus, $2-2 \cdot 5 \mathrm{~mm}$. high. The sporangium is covered with an exceedingly thin layer of some substance resembling the bloom on a plum, which may be lime; it cracks and breaks up into angular patches in water.

Lamproderma Schimperi, Rost.

Sporangia spherical, green, becoming blackish, or with a 
reddish metallic sheen; stem black, shining, rigid, subulate, entering the peridium as an obovate columella, and about half its height; capillitium of dusky threads springing from apex of columella, branches for some distance simple, then becoming very much branched, laterally connected, and forming a dense net at the periphery, spores dingy-violet, minutely spinulose, $10^{\circ}-11 \mu$ diameter.

Lamproderma Schimperi, Rost., Mon., p. 203, fig. 63; Sacc., Syll., n. 1343; Cke., Myx. Brit., fig. 63.

Germany.

\section{Lamproderma Santeri, Rost.}

Similar to $L$. violaceum, but more rigid in every part; sporangia spherical, slightly flattened below, $1 \mathrm{~mm}$. broad, shining with various metallic tints; stem black, subulate, springing from a well-developed hypothallus; columella cylindrical, truncate; capillitium threads branched from the base and forming a dense network, pale when the spores are blown away; spores dingy-violet, densely covered with spinules, 12-15 $\mu$ diameter.

Lamproderma Sauteri, Rost., Mon., p. 205; Sacc., Syll., vii., 1, no. 1348.

Tyrol.

Entire specinen $2 \mathrm{~mm}$. high.

Lamproderma minutum, Rost.

Sporangia spherical, $\frac{3}{5} \mathrm{~mm}$. diameter, slightly metallic; stem black, slender, equal; columella cylindrical, thin, truncate; threculs of copillitium colourless, rarely fasciculately branchod, fuscicles blculing together; spores violet, delicatcly verriculose, $6.6 \mu$ diameter.

Lamproderma minutum, Rost., Mon., Append., p. 26 ; Sacc., Syll., vii., 1, n. 1351.

France.

Lamproderma columbinum, Rost.

Sporangia stipitate, sub-ovate or globose, blackish, reflecting 
variously coloured metallic tints; stem slender, attenuated upwards, longitudinally wrinkled below, purple-black; columella cylindrical, more or less attenuated at the apex, about half the leight of the sporangium; capillitium pale, primary branches short, but distinct, thick, soon branching and dichotomosing in an irregular manner, combined by transverse branches to form an irregular network with numerous free, thin tips; spores globose, pale violet, minutely warted, 12-16 $\mu$ diameter.

Lamproderma columbinum, Rost., Mon., p. 203, f. 61 ; Cke., Myx. Brit., f. 61 ; Sacc., Syll., n. 1345.

Lamproderma iridescens, Rost., Mon., App., p. 25 ; Sacc., Syll., n. 1346.

Physarum iridescens, Berk., Hook. Journ., 18ว̃1, p. 20.

Exsicc.-Rab., Fung. Eur., 2213; Roum., Fung. Gall. Exs., n. $168 \check{5}$.

On moss, wood, \&c. Britain (Orton Wood, Leicester; Rudloe, Twycross, Carlisle); Europe; United States.

From 2-3 mm. high, sometimes sessile and even aethalioid; distinguished by the very short, stout, primary branches of the capillitium, the smaller branches are sometimes nodulose at intervals.

(Rostafinski's Synonyms.)

Mucor violacens, Leess., Fl. Herb., n. 1128 (1775).

Trichia violacea, Hoffm., Veg. Cr., p. 5, t. 2. f. 1 (1790).

Physarum columbinum, Pers., Syst., p. 173 (1801).

Trichia columbina, Poir., Encycl., no. 17 (1808).

Physarum salicinum, Schum., Fl. Saell., n. 1431 (1803).

Physarum bryophilum, Fr., S. M., iii., p. 135 (1829).

Plysarum bryophilum, $\beta$ melanocephalum, Cda., Ic. 1, p. 22 , t. 4, f. 287 (1837).

\section{Lamproderma Saccardianum, Mass.}

Broadly gregarious, altogether blackish, sporangia perfectly spherical, not umbilicate, $\frac{1}{4} \mathrm{~mm}$. broad, at first yellowish then opaque black, smooth, persistent, erect; stem filiform, $\frac{1}{2} \mathrm{~mm}$. high, $40 \mu$ thick, black; hypothallus (when evident) distinct, minute, rufescent; columella terete, half the height of the 
sporangium, apex rather obtuse; branches of the capillitium springing from apex of columella, dichotomously tranched, filiform, fuliginous; spores globose, $9-10 \mu$ diameter, pale smokyviolet, minutely cehinulate.

Lamproderma nigrescens, Sac., Michelia, II., p. 262 ; Sacc., Syll., vii., 1, no. 1354 (not of Rost.).

On fallen leaves of Buxus, Robinia Pinus, heaps of chips, \&c. Selva, N. Italy.

Distinguisher from L. physarioides by its smaller size and smaller spores, and from L. violaceum by the black spherical sporangium, etc. (Sacc.)

Saccardo's name is antedated by Rostafinski's.

Lamproderma arcyrioides, Rost. (figs. 145-148).

Gregarious or scattered, springing from a firm hypothallus; sporangia globose, shortly elliptical or obovate, wall thin, blackish, with blue, purple, green, or reddish metallic tints; stem usually becoming thinner upwards, blackish, shining, sometimes obsolete, passing directly into the sporangium as a short columella that breales up at the apex into several cqual, ascending branches, these again produce numerous lateral Iranclucs, at some distance from the base, that ancstomose laterally and form a dense, irregular network, threads pale greyishbrown; spores globose, dirty violet, minutely warted, 11-16 $\mu$ diameter.

Lamproderma areyrioides, Rost., Mon., p. 206; Cke., Myx. Brit., p. 50 ; Sacc., Syll., vii., n. 1353.

Lisicc.-Rab., Herb. Myc., 4:31 ; Roum., Fung. Gall., 908; Fuckel., Fung. Rhen., 1447 ; Rab., Fung. Eur., 797.

On rotten wood, dead leaves, \&c. Britain (New Forest, Scarborough, Carlisle); France; Germany ; Sweden; Denmark ; United States.

From 1.5-3 mm. high. Near to $L$. violacea, but distinguished by the larger and more coarsely warted spores, and in the main branches of the capillitium remaining unbranched for some distance at the base. 
(Rostafinski's Synonyms.)

Stemonitis areyrioides, Somm., Tidsk. (1827); Berk., Ann. N. Hist., No. 114; Cke., Hdbk., n. 1163.

Stemonitis chalybea, Pers., in litt.

Stem.onitis Carestice, Ces. and Not. (1861); Erb. Cr. Ital., 888.

Stemonitis Morthieri, Fckl., Exs., n. 1447 (1860).

Lamproderma physarioides, Rost.

Gregarious or scattered; sporangia globose, wall pale, with a silvery sheen, stem elongated, tapering upwards, base expanding into a small circular hypothallus, black; columella about onethird the height of the sporangium, clavate; threads of capillitium purple-brown, springing from the clavate portion of the columella, repeatedly brainehing in a dichotomons manner, the branches anastomosing to form a network, becoming dense and small meshed towards the periphery; spores globose, brown, minutcly verruculose, $11-15 \mu$ diameter.

Lamproder'ma physarioides, Rost., Mon., p. 202 ; figs. 55, 59, 62 ; Cke., Myx. Brit., p. 49, figs. 55, 59, 62; Sacc., Syll., vii., n. 1342.

On rotten wood, moss, \&c. Britain; Germany; U. States.

Distinguished by the pale, silvery sporangial wall, the clear brown spores, and the clavate columella; $2-3.5 \mathrm{~mm}$. high.

(Rostafinski's Synonym.)

Stemonitis physarioides, A. and S., Consp., t. 11, f. 8 (1805); B. and Br., Ann. Nat. Hist., no. 386; Cke., Hdbk., no. 1161.

\section{Spores reticulated.}

\section{Lamproderma Fuckelianum, Rost.}

Sporangia globose, almost sessile, slightly umbilicate below, reddish, metallic; stem from its shortness almost inconspicuons, entering the peridium for nearly half its length as a conical columella; threads of the capillitium sparingly branched, combined into a loose network; spores pale violet, with thin ridges combined to form a network, 8-9 $\mu$ diameter. 
Lamproderma Fuckclianum, Rost., Mon., p. 207 ; Sacc., Syll., vii., 1, n. 1347.

Germany.

Distinguished more especially by the reticulated epispore.

Lamproderma Lycopodii, Raunk.

Sporangia single, globose, sessile, on a violet-brown hypothallus. Wall, columella, capillitium, and spores violet-brown. The lower part of the wall remains, with irregular, tattered margin. Columella cylindrical, nearly reaching half the height of the sporangium. Capillitium originating singly from the upper part of the columella, in continuation forked more and more, especially at the surface of the sporangium, combined into a net by transverse branches, extremities rather colourless, Spores 12-18 $\mu$ diameter, on the surfucc furnished with a dclicatc nctivor\% of fine thickenings.

Lamproderma Iycopodii, Raunk., Myx. Dan., p. 108 (in English).

\section{(Raunkier's Synonyms.)}

Stcmonitis cribraricules, Fries, Syst. Myc., iii., p. 163; Sacc., Syll., vii., 1, no. 1370.

Cribraria Lycopcrdi, Nees, in litt.

On the leaves of Iycopodium annotinum.

Sealand.

\section{Enerthenema, Bowm.}

Sporangial wall very thin, fragile, soon disappearing; sten continuing as a columella quite through the sporangium and expanding at its apex into a discoid membrane from which the capillitium originates; capillitium of slender, sub-equal threads which bifurcate and anastomose more or less laterally, tips free; spores free or at first in clusters.

Enerthcncma, Bowman, Trans., Linn. Soc. (1828), xvi., p. 151 ; Rost., Mon., p. 209 ; Cooke, Myx. Brit., p. 51; Raunk., Myx. Dan., p. 92 ; Sacc., Syll., v. 7, p. 402. 
A well-marked genus, characterized by the capillitium originating solely from the peltate, flattened apex of the columella; capillitium dense, threads coloured, thin, sub-equal, branching in a dichotomous or irregular manner, main branches frequently connected by transverse bars, tips free; that is, not combined into a net, but evidently in many instances showing indications of having originally been attached to the inside of the evanescent sporangial wall. Connected with the typical structure met with in the Columelliferae by Raunkier's genus Ancyrophorus, which agrees with Enerthenema in having the columella dilated at the apex, but the capillitium originates from the columella throughout its length as well as from the disc, and the tips of the threads are not so decidedly free from anastomosing as in the present genus.

Distrib. Europe; United States; New Granada. Sp. 3.

Enerthenema elegans, Bowm. (figs. 302-304).

Sporangia globose, with usually a minute apical umbo, wall very thin, brownish, iridescent, fugitive; stem thick, conical, blackish-brown, opaque, continuing as a thin columella quite through the sporangium and supporting the pendulous capillitium from its apical disc, threads of capillitium brown, sub-equal, $2.5-3 \mu$ thick, often minutely and irregularly nodulose; spores globose, free from the first, very indistinctly verruculose, 8-10 $\mu$ diameter.

Enerthenema clegans, Bowman, Linn. Trans. (1828), xvi., p. 151, t. 16 ; Rost., Mon., p. 209, figs. 45, 48, 49, 52, 57.

Enerthenema papillata, Rost., Mon., App., p. 28; Cooke, Brit. Myx., p. 51, figs. 45, 48, 49, 52, 57 ; Sacc., Syll., no. 1378; Raunk., Myx. Dan., p. 92, t. 5, f. 7 .

Britain (Wothorpe, Carlisle, Edinburgh); Germany ; Finland ; United States.

On wood and bark. From 1.5 to $2 \mathrm{~mm}$. high, wall of sporangium disappearing very early, hence the plant is usually met with having the capillitium streaming from the discoid apex of the columella. 
Owing to an oversight, Enerthenema-Berkeleyana was introduced by Cooke in Myx. Brit., p. 51, as a native of Britain. This species, so far as I am aware, has only been met with in S. Carolina, and is known by the clustered spores.

\section{(Rostafinski's Synonyms.)}

Arcyria atra, Schum., Saell., no. 1487; Fl. Dan., t. 4194 (1803).

Enerthenema clegans, Bowm., Trans. Linn. Soc., xvi., p, 151, t. 16 (1828).

Stemonitis mammosa, Fr., iii., 161 (1829).

Stcmonitis papillata, De Bary, l.c. (1859).

Encrthenema phocnicolepta, Bowm., msc.

\section{Enerthenema Berkeleyana, Rost.}

Sporangia stipitate, globose, blackish, wall evanescent; stem black, very thick at the base, conical, becoming contracted into a thin, cylindrical, black columella that reaches to the apex of the sporangium, and there becoming expanded into a disc; capillitium threads dark, springing from the margin of the disc, pendulous, sparingly forked, rarely joined laterally; spores blackish-purple in the mass, at first in elusters of 4-14, subtriangilar at first, free portion warted, 10-13 $\mu$ diameter.

Enerthenema Berkelcyana, Rost., Mon., Append., p. 29 ; Cke., Myx. Brit., p. 51 .

(Type in Herb. Berk., Kew, no. 10888.)

On boards. South Carolina.

Closely resembling $S$. elegans, but distinct in the clustered spores that are warted on the free surface only. The stem is not always thickened below.

\section{Enerthenema muscorum, Lév.}

Gregarious, black; stem setaceous, smooth, expanding at the base into a shield-like hypothallus; sporangium smooth; tubes of the capillitium springing from the lenticular apex of the 
columella; simple for some distance, then branched in a dichotomous or vague manner; spores globose, brown.

Enerthenema muscorum, Lév., Ann. Sci. Nat., Ser. IV., vol. xix., p. 289 (1863); Sacc., Syll., vii., 1, no. 1380.

On moss. New Granada.

The information respecting the present species is insufficient to indicate its specific features with exactness.

\section{ANCYrophorus, Raunk.}

Sporangium stipitate. Stem prolonged within the sporangiun as a columella, reaching the apex of the sporangium and there expanding into a discoid membrane. Capillitium originating from this stout discoid membrane, and from the upper part of the columella proper. Threads of the capillitium only towards the extremities inconsiderably forked, the extreme branches arcuate and furnished with numerous subulate spines.

Ancyrophorus, Raunkier, Myx. Dan., in Bot. Tidsskrift. (Journ. Bot. Soc. Bot. de Copenhague), 1888, p. 92, and 1889, p. 110 (in English).

Clossly allied to Enerthenema, known by the branches of the capillitium springing from the upper portion of the stem as well as from its discoid apex.

Distrib. Denmark. Species 1.

\section{Ancyrophorus crassipes, Raunk.}

Sporangia globose, stipitate. Stem shorter than the sporangium, from an exceedingly thick base lengthened directly into the subulate columella. Threads of capillitium combined by very few transverse branches. The extreme branches arcuate, and provided with numerous subulate spines. Stem, columella, and capillitium dull violet-black. Spores smooth or delicately warted; bright violet, $10-12 \mu$ diameter.

Ancyrophorus crassipes, Raunk., Myx. Dan., p. 93 (1888), and p. 110 (1890) in English.

On rotten wood. Denmark. 
Raciborskia, Berl.

Sporangia naked, globose, stipitate, stem elongated, entering the sporangium as a columella from one-third to half its height, bearing at the apex secondary, short, slender eolumellas, these in turn divide in a similar manner to the primary columella; ultimate branches combined amongst themselves at every point to furm a network; extreme branchlets not free but arcuately combined with each other.

Raciborslia, Berlese, Sace., Syll., vii., pt. I., p. 400.

liostafinsliu, Racib., Myx. Crac., p. 9 (not of Spegazzini).

Distrib. Poland. Species 1.

\section{Raciborskia elegans, Berl.}

Sporangia naked, globose, up to $\cdot 5 \mathrm{~mm}$. broad, stem erect, 1-2 $\mathrm{mm}$. high, thickest at the base, then subulate-attenuated, plicate, black; eolumella half to one-third shorter than the sporangium, cylindrical, 8-10 $\mu$ thick; capillitium blackishviolet, exterior threads exceedingly thin, not free; the extreme branches furnished with scattered spines; spores $9-10 \mu$ diameter, obscure violet, aculeate.

Raciborstia clegans, Racib., Myx. Crac., p. 10, fig. 5.

Poland.

Raeiborski considers that the present species is allied to Rostafinski's genus 'Echinostelium. He also inclines to the idea that the genus Orthotricha may prove to be identieal with his Raciborskia (= Rostafinskiu, Racib.).*

\section{Echinostelium, De Bary.}

Sporangia stipitate, columella absent, eapillitium originating from apex of stem, threads arcuate, combined to form a lonse network, furnished with numerous spine-like free arms.

Echinostelium, De Bary, in Rost., Mon., p. 215; Cooke, Brit. Myx., p. 53. 
Echinostelium minutum, De Bary (fig. 202).

Sporangia scattered, stipitate, globose, naked, whitish; the arcuate threads of the capillitium springing from the apex of the stem, furnished with numerous acute, free branches; spores coloured, $6.7-8.3 \mu$ diameter, smooth.

Echinostelium .minutum, De Bary, in Rost., Mon., p. 215, figs. 53, 54, 58, and 68; Cke., Brit. Myx., figs. 53, 54, 58, 68; Sacc., Syll., vii., 1, no. 1340.

\section{Orthotricha, Wingate.}

Sporangium globose; stipe elongated, entering the sporangium as a very short or obsolete columella, and then dividing into a few branches at a sharp angle. These branches fork several times, thus forming a capillitium of straight threads. The last branches meet at the surface of sporangium at a very sharp angle by twos or threes, where they are joined together by small membranaceous plates. Wall of the sporangium, with the exception of the plates and a very small collar around the stipe, not apparent.

Orthotricha, Wingate; Proc. Acad. Nat. Sci. Phil., 1886, p. 125 ; Sacc., Syll., vii., pt. I, p. 400.

Distrib. United States. Sp. 1.

Orthotricha microcephala, Wingate.

Sporangia globose, very variable in size, from one-twelfth to one-fourth of a mm. in diameter; stipe elongated, brown or blackish at the base, growing lighter towards the top, more or less translucent, ten to thirty times the diameter of the sporangium in height, tapering, rugose, except at the upper part, where it more or less suddenly becomes a smooth filament, entering the sporangium as a very short, sometimes almost obsolete columella. It then divides into a few (sometimes only two) branches at a sharp angle. These branches fork several times, forming a very loose capillitium of straight threads, the 
last branches meeting at the surface of the sporangium by twos or threes at a very sharp angle, where their slightly thickened ends are joined together by minute, membranaceous plates. Sporangium wall not apparent, except a slight collar around the stipe as it enters the sporangium; spores brown in mass, very light-violet, almost colourless, under the microscope, perfectly smooth, 7-8 mm. in diameter.

On rotten logs, Philadelphia, $\mathrm{Pa}$.

This plant has been found during three seasons in Fairmont Park, Philadelphia, Pa., in many localities. The plasmodium has a dirty-brown colour. When erecting, the dark, granular substance of the mass is left in the matter which is to form the stipe, and the globule of the sporangiun becomes milky white. Before the stipe has reached its full height, say in the upper fifth, the sporingium mass leaves behind it, clustered around the stipe, several (2-8) clear, highly-refractive, minute globules, which, in a recently-matured plant, sparkle like dewdrops. The plant continues erecting, but from the place where the globules are left behind, the stipe very frequently suddenly narrows, sometimes to a mere filament. As the plants become old, the dew-like globules become amber-coloured, but remain transparent. These clear globules have been occasionally noted by the writer on the sporangium wall of Comatrichas, and have been considered as an indication of some degree of immaturity, hence they have not been mentioned in the description as having a specific value. In the plants, as found in different places, they are constant, though sometimes fused into one mass. The finer filaments of the capillitium, in fluid under the microscrope, are almost colourless. The plants are more or less sociable, sometimes forming patches an inch or so in diameter, and may readily be mistaken for a mould. (Wing.)

Orthotricha microccphala, Wingate, in Proc. Acad. Nat. Science, Philadelphia, 1886, p. 125 ; Sacc., Syll., vii., pt. I., n.

Exsicc.-Ellis and Everhart, N. Amer. Fung., Ser. II., n. 2498.

A very beautiful and at the same time puzzling form. I am not at all convinced in my own mind as to whether the present genus belongs to the present division or to the Peritricheac. 


\section{CALOTRICHEAE.}

The varied types of ornamentation under the form of warts, spines, or raised bands, often arranged in the form of half-rings, or anastomosing to form a network on the surface of the capillitium tubes, constitute the most pronounced character of the present order. In connection with spore dissemination, the capillitium here reaches its highest development, due to the elasticity of the tubes, which are never rigid with lime, and in the most perfect genera are quite free from the sporangial wall. The elasticity is not due to stretching, but to the sudden straightening out of previously coiled-up tubes. If an immature sporangium of Arcyria cinerca having the spores and capillitium fully differentiated, is hardened in alcohol, a section shows the tubes of the capillitium, which are combined to form a network, to be much contorted, and consequently shortened so that the net-like structure is not evident, the interspaces between the convolutions of the tubes being filled with spores. This arrangement of parts continues until the spores are mature, and owing to the disappearance of water, form a powdery mass, when the coiled-up tubes straighten out and the network becomes fully expanded, resulting in an increase of ten or more times in the length and breadth of the capillitium. This expansion takes place suddenly, with the result that the mass of spores are carried up and dispersed. During the expansion of the capillitium the sporangial wall is torn into fragments, and disappears with the exception of a small portion at the base which, owing to its firmer consistency and comparative freedom from the expansion exerted by the capillitium, remains in the form of a cup or calyculus. In the genius Trichia the free tubes or elaters are very much coiled up and contorted until the spores are mature, when by suddenly straightening out, the wall of the sporangium is ruptured and some of the spores thrown out, but the arrangement is not so perfect as in Arcyria. In some of the comparatively imperfect genera, as Perichacna, the capillitium is scanty or obsolete. Yellow is the predominating 
colour of the spores as seen in the mass, passing in some species to deep orange and orange-brown; similar colours are met with in the sporangial wall. In the genus Perichaena the inner surface of the sporangial wall is frequently covered with a layer of amorphous granules of lime. In stipitate forms of some species belonging to the genera Arcyria, Heterotrichic, and Trichia, the stem is filled with cells which are either spherical or polygonal from mutual pressure. These cells, when young, contain protoplasm, and the wall gives a cellulose reaction; they are usually largest at the base of the stem, and become smaller upwards, passing insensibly into normal spores at the point where the stem expands into the sporangium. The tubes of the capillitium frequently pass down between these cells into the stem. It would appear as if the stem cells had originally been intended for true spores, but owing to the contraction of the base of the sporangium into a stem had been checked in their development.

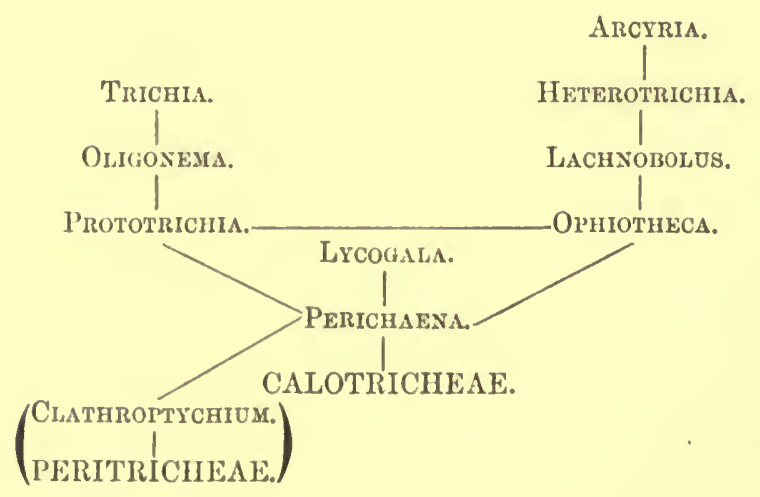

\section{ANALYSIS OF THE GENERA.}

\section{CALOTRICHEAE.}

Sub-sect. Tricheae.

Elaters free, not forming a network.

Trichis. Elaters with well-developed spirals.

Oligonema. Elaters without distinct spirals. 


\section{Sub-sect. ArcrriaE.}

Elaters attached to wall of sporangium only slightly branched or forming a network.

Prototrichia. Elaters fixed by one end to base of sporangium, tips free.

Perichaena. Sporangial wall with a layer of lime granules inside; capillitium scanty.

Ophiotheea. Threads of capillitium usually spiny, of equal thickness, forming a net with numerous blunt, free arms.

Heterotrichia. Threads of capillitium of two distinct thicknesses, forming a net, outer network with numerous free, pointed arms.

Lachnobolus. Threads of capillitium forming a network attached at numerous points to wall of sporangium.

ARCYRIA. Threads of capillitium forming a network usually elastically protruded at maturity.

Lycogala. Cortex containing numerous cells filled with protoplasm, capillitium tubes thick.

\section{Sub-sect. Arcyriae.}

\section{Perichaena, Fries.}

Sporangia sessile, gregarious, dehiscing irregularly or in a circumscissile manner, wall usually double, the outer often containing granules of lime or a layer of granules of organic matter; capillitium variously developed, in some species forming an irregular network attached at various points to the upper portion of sporangial wall, in other species almost obsolete, threads of the capillitium without definite markings, either quite smooth or with a few scattered, rudimentary spinules or notch-like constrictions; spores globose.

Periehaena, Fries, Gast., p. 12 ; Rost., Mon., p. 292 ; Cooke, Myx. Brit., p. 77 ; Zopf, p. 169; Sacc., Syll., vii. pt. I., p. 420.

The most prominent generic features are the circumscissile dehiscence of the sporangium, which however is not universal, the layer of amorphous particles of lime or of organic matter 
inside the sporangial wall, and the smooth or obsoletely marked threads of the capillitium. The present genus is allied to Arcyria; in Arcyria paradoxa we meet with lumps of lime and of organic matter on the inner surface of the sporangial wall, but the capillitium is characteristic of Arcyria.

The present genus is yet more closely allied to Ophiotheca; in fact it is impossible to say where one ends and the other commences; in Pcrichacna the capillitium threads are typically without external markings, whereas in Lachnobolus the threads have distinct raised markings, but in each genus species occur deviating from the typical idea and in the direction of the other genus, and it is doubtful whether the presence or absence of markings on capillitium threads alone, even if constant, is of sufficient value to constitute a generic distinction.

Distrib. Europe; Borneo; W. Australia; Canada; United States. Species 9.

Perichaena depressa, Libert. (figs. 118-120).

Sporangia usually gregarious or much crowded, polygonal from mutual pressure, very mach depressed, and almost plane above, dehiscing in a circumscissile manner, brown, sometimes with a purple tinge, polished; mass of capillitium and spores bright orange-yellow ; capillitium usually well-developed, threads variable in wilth, smooth, rarely notched or furnished with rudinentary scattered spinules; spores globosc, minutely warted; 9-12 $\mu$ dianeter.

Perichacna depressa, Lib., Pl. Cr. Ard., Fasc. IV., n. 378; Rost., Mon., p. 292; Cke., Myx. Brit., p. 77 ; Sacc., Syll., 1434; Raunk., Myx. Dan., p. 54.

Exsice.-Sacc., Myc. Ven. 500 ; Ellis, N. Amer. Fung., 1218; Roum. Fung. Gall., 2113; Fuckel., Fung. Rhen., 2200; Lib., Pl. Crypt. Ard., Fasc. IV., n. 378.

On wood, \&c. Up to $1 \mathrm{~mm}$. diameter. Characterized by the very much flattened sporangia and bright yellow mass of spores.

Britain (Carlisle); Germany; Bohemia; Belgium; Italy ; France; United States. 
(Rostafinski's Synonyms.)

Perichaena vaporaria, Schw:, Am., 2311 (1831).

Perichaena depressa, Lib., Exs., n. 378 (1837).

Stegasma depressum, Cda., Ic. V., f. 13 (1842).

Perichaena corticalis, Rost. (figs. 114-117).

Sporangia spherico-depressed, crowded, dehiscing in a circumscissile manner, lid convex, brown, bluish-purple, sometimes whitish, smooth; mass of capillitium and spores pale yellow; capillitium scanty, sometimes almost obsolete, threads thin, smooth, or here and there notched; spores globose, warted, warts variable in size, sometimes very indistinct, at others welldeveloped, never smooth, $9-12 \mu$ diameter.

Perichaena corticalis, Rost., Mon., p. 293, figs. 188; Cke., Myx. Brit., 78, fig. 188; Sacc., Syll., n. 1435 ; Raunk., Myx. Dan., p. 53.

Perichaena fusco-atra, Rost., Mon., p. 294; Cke., Myx. Brit., 78; Sacc., Syll., n. 1436.

Perichaena quercina, Fr., Gast., p. 12. (Specimen from Fries in Herb., Kew.)

Exsicc.-Sydow, Myc. March., 1669; Karst., Fung. Fenn., 179 ; Fuckel., Fung. Rhen., 1899; Berk., Brit. Fung., 47; Desm., Cr. Fr., Ser. I., 671.

On bark and wood. Britain (Lyndhurst, Kew, Derby, Castle Howard, Yorks; Carlisle, Edinburgh, Appin, N. B.); Europe; Canada; United States; W. Australia; Ceylon.

Very closely allied to $P$. depressa, if indeed really distinct as a species, the less depressed sporangium and scanty capillitium are the distinguishing features of the present species.

In some specimens the wall of the sporangium has a dense layer of angular particles of lime, and is consequently nearly or quite white externally, in others the lime is scanty and in its place a layer of amorphous, coloured granules of organic matter which give the brown or reddish-purple colour to the sporangial 
wall. The spores vary in markings from vague granulations to well-defined warts.

(Rostafinski's Synonyms.)

(Perichaena corticalis).

Lycoperdon corticale, Batsch. El., p. 155 (1783).

Sphacrocarpus sessilis, Bull., t. 417, f. 5 (1791).

Trichia gymnosperma, Pers., Obs., vi., f. 1, 2 (1796).

Trichia circumscissa, Schrad., p. 19 (1797).

Licca circumscissa, Pers., Syn., 196 (1801).

Physarum lnteo-cellum, Schum., Saell., 1430 (1803).

Tubulina circumscissa, Poir., Ency., viii., j (1808).

Perichacna populina, Fr., Gast., 12 (1817); Grev., t. 252;

Eng. Fl., r., 321 ; Cooke, Hdbk., No. 1192.

Pcrichaena populina, $\beta$ sorbea, Weinm. in Fr. S. M., iii., 192 (1829).

Pcrichaena quercina, Fries, Gast., p. 12 (1817).

Trichia varia subrufescens, Bong. Herb.

Licea quercince, Wallr. Fl. Cry., 2103 (1833).

Licca artocreces, B. and Rav., Fungi Car., ii., 82.

Perichacna artocreas, B. and Rav., Grev., No. 370 (1873).

\section{(Pcrichaena fusco-atra.)}

Mucor lycoperdioides, Scop. Ann., iv., t. 1, f. 11 (1772).

Trichia fresco-atra, Sibth. Fl. Ox., 1152 (179ł).

Sphacrocaryus sessilis, Sow., t. 258 (1803).

Licea circumscissa, $\beta$ abictina, A. and S., p. 108 (1805).

Perichaena abietina, Fr., Gast., p. 17 (1817); Eng. Fl., v., 321 ;

Cooke, Hdbk., No. 1191.

Perichacna microcarpa, Sauter. Rabh. DC. Fl., No. 2180 (1844).

\section{Perichaena applanata, Mass.}

Sessile, adnate on a broad base, much depressed, circular in outline or aethalioid and irregular, dehiscing in an irregularly circumscissile manner, wall with a dense layer of granules of lime on its iuner surface, bright bluc-grcy; mass of capillitium 
and spores clear orange-yellow ; capillitium rather scanty, forming a loose net, threads $3-5 \mu$ diameter, sometimes notched or with scattered rudimentary spinules; spores globose, minutely warted, $11-12 \mu$ diameter.

Hemiareyria applanata, Cke. and Mass., Grev., vol. xvi., p. 20.

On wood. Brisbane.

(Type in Herb., Kew.)

From 1-2 $\mathrm{mm}$. diameter. Readily known by the bright grey sporangium and the clear orange spore-mass. The present species, owing to superficial examination, was originally described as a Hemiarcyria.

\section{Perichaena microcarpa, Schröet.}

Sporangia distinct or confluent in minute clusters, generally globose, $0.5 \mathrm{~mm}$. diameter, rarely unequal, depressed, yellowbrown, smooth, dehiscing irregularly; capillitium well-developed, threads golden-yellow, $1 \cdot 5-2 \mu$ thick, combined to form a loose, regular net, thickened at the angles, smooth; spores golden-yellow, globose, $15-17 \mu$ diameter, epispore strongly aculeolate.

Perichaena microcarpa, Schröeter, Krypt. Fl. Schles. Pilze, p. 108; Sacc., Syll., vii., pt. I., n. 1445.

On rotten leaves. Silesia.

\section{Perichaena Rostafinskii, Karst.}

Sporangia scattered or sub-gregarious, sessile, spherical, yellowish then bay, shining; capillitium obsolete; spores globose, smooth, or nearly so, in the mass blackish-brown, brownish under the microscope, variable in size, $10-27 \mu$ diameter.

Perichacna Rostafinskìi, Karst., Myc. Fenn. IV., p. 130 ; Sacc., Syll, n. 1444.

On dead moss, rotten leaves, \&c. Finland.

The variability in the markings and size of the spores suggests that Karsten has had an immature species under consideration.

Perichaena confusa, Mass. (n. sp.).

Sporangia hemispherical and seattered or aethalioid, and often forming an irregular network, pale umber or dingy ochraceous, 
dehiscing irregularly; capillitium well developed, forming an irregular, loose network, threads 2-4 $\mu$ thick, irregularly notched; spores globose, smooth, 13-14 $\mu$ diameter; mass of capillitium and spores dingy ochraceous, sometimes with a suggestion of olive.

\section{(Type in Herb., Kew.)}

Exisice.-Ellis, N. Amer. Fung., n. 726 (as Ophiotheca umbrina, Berk.).

On wood, leaves, \&c. Britain (Lyme Regis, Yatton); U. States.

Berkeley's description of Ophiotheca umbrina is very imperfect, as shown by examination of his type specimen, which proves to be identical with Physamum vermiculare, Sz. Rostafinski had not seen Berkeley's type, but gave the original description and changed the name to Perichaena variabilis, Rost. Berkeley's imperfect description of Ophiotheca umbrina curiously agrees in many points with the present species which was unknown to him. Rarely with simple, normal sporangia, usually elongated and curved, forming rings, flexuous vein-like strands, or combined to form a network. The species is a connecting link between Perichacna and Opliotheca, having the capillitium of the former without distinct markings, but the peculiar habit of Ophiotheca.

\section{Perichaena liceoides, Rost.}

Sporangia globose, scattered or gregarious, dehiscing in an irregularly circumscissile manner; spores smooth, globose, 9-10 $\mu$ diameter; capillitium scanty, threads slender, branched, witl minute included granules.

Perichaena liceoülcs, Rost., Mon., p. 295 ; Sacc., Syll., vol. vii., part I., n. 1438.

Licca pannomum, Cienk., Pringsh. Jalıb., vol. iii., p. 407, t. 17, fig. 1 (not of Wallr.).

On leaves. Germany.

Doulbtful species.

Perichaena pallida, Berl.

Sporangia gregarious, very pale tan colour; spores yellow, 
but paler than in Perichaena australis, whose chestnut-coloured sporangia and intense golden spore-mass distinguish it froin the present species.

Perichaena pallida, Berl., Sacc., Syll., n. 1446.

s.tegasma pallidum, Cesati, Myc. Born., p. 12.

Borneo (Sarawak).

Perichaena australis, Berl.

Sporangia often circinnate, angular, central ones orbicular, at first yellow, passing through chestnut to brown, smooth, lid plane; capillitium yellow; spores sub-globose, granular within, opaque, yellow.

Perichaena australis, Berl., Sacc., Syll., vii., 1, n. 1447.

Stegasma australe, Cesati, Hedwigia, 1874, p. 186.

Borneo.

Perichaena? pseudaecidium, Speg.

Sporangia cylindrical, conical, or calyciform, 1-1.5 mm. long, by $0.5-1 \mathrm{~mm}$. broad, sessile or shortly stipitate, wall very thin, cartilagineo-membranaceous, base even or minutely rugulose, dehiscing at the apex in an irregularly laciniate or fimbriate manner, chestnut or brownish; mass of spores and capillitium. citrin or yellowish; capillitium threads very slender, $1 \mu$ thick, sparingly branched, here and there with solitary conical or elongated branch-like spines, yellowish, hyaline; spores globose, $6-7 \mu$ diameter, often irregularly angular from mutual pressure, perfectly smooth, pale vinous with yellow tinge.

Perichacna? psendaecidium, Speg., Fung. Guar., n. 321.

On living fronds of many different species of fern, and on Tillandsia muscoides.

Argentine Republic.

A very beautiful but paradoxical species exactly resembling a folicolous Accidium, will probably form the type of a new genus (Speg.). Possibly a sp. of Chondrioderma.

Lycogala, Mich.

Sporangia aethalioid, grouped together in an intricate manner, 
and forming a large plasmodiocarp, enclosed in a well-defined, thick, common cortex, enclosing near the outer side numerous cell-like masses of protoplasm; capillitium originating at numerous points in the inner portion of the cortex, forming an irregular, loose net with numerous free ends, threads ornamented with warts or raised bands forming irregularly arranged rings, spirals, or anastomosing to form a network; spores globose.

Inycogala, Mich., Rost., Mon., p. 285; Cooke, Myx. Brit., p. 74 ; Sacc., Syll., v., 7, pt. I., p. 435.

Iycoperdon, Bux., p. 203.

Dermodium, Rost., Mon., p. 284; Sace., Syll., p. 434; Cke., Myx., p. 74.

The species resemble those of Reticularia in "their large size, forming hemispherical or irregularly elongated masses up to four inches in diameter. The stout cortex covering the interwoven mass of aethalioid sporangia presents a complicated structure. In L. cpidendron, the most highly evolved species, the cortex contains towards the outside numerous irregularlyshaped coloured masses of protoplasm of various sizes, each surrounded by a special wall; these are sometimes so numerous as to present the appearance of elosely aggregated polygonal cells when seen in section. The tubes of the capillitium originate in the thick cortex from the cells of protoplasm just described, and frequently combine to form an irregular reticulation in the substance of the cortex; in this position the tubes are very thick, reaching to '20 $\mu$ 'in diameter, and consist, as it were, of two tubes, one enclosed within the other; the outer tube, the wall enelosing the protoplasm, has very thick, perfectly smooth, colourless walls, and disappears at the point where the eapillitium breaks through the walls to enter the mass of aethalia forming the plasmodiocarp. The inner tube has a very thin, faintly-tinged wall furnished with intermixed warts and raised bands anastomosing to form an irregular network; the inner tube is completely surrounded by the outer at its apex, until the whole structure has grown beyond the inner surface of the cortex, when the inner tube pushes through the apex of the outer smooth tube and alone forms the capillitium. The outer 
common cortex cannot in the present instance be considered as excretory, and solely for protective purposes, but must be considered as a living portion of the organism giving origin to the complex capillitium, the tubes of which appear to increase in length by apical growth. The tubes of the capillitium that enter the aethalia collapse before the spores are mature, and consequently exercise no dispersive function. The scheme of classification adopted in the present work, I much regret to say, is founded mostly on characters presented by mature forms, hence the elaborate ornamention of the capillitium tubes places the present genus in the sub-family Calotrichcae; whereas, if the capillitium is a continuation of the cortex, or rather a development directly from the cortex, Peritricheae would be its proper position.

Distrit. Cosmopolitan. Species 6.

Lycogala epidendrum, Rost. (figs. 121, 122).

Plasmodiocarp sub-globose, gregarious or rarely solitary, $\cdot 5-2$ $\mathrm{cm}$. diameter, surface minutely warted, variable in colour, rosered, dingy vermilion, or brownish red; threads of capillitium almost colourless, 8-12 $\mu$ thick, springing from the cortex, becoming irregularly branched with various free, slightly incrassated tips, now and then anastomosing laterally, furnished with warts, short bands, irregular rings or spirals, or with the raised bands anastomosing to form an irregular network; frequently all the above modifications may be seen on the same tube, wall thin and soon collapsing; spore-mass variable in colour, dingy purple, flesh-colour, greyish-yellow, or sometimes with a dingy green tinge, spores globose, minutely but distinctly warted, $4-6 \mu$ diameter.

Lycogala epidendrum, Rost., Mon., 85, figs. 1, 7-12; Cke., Myx. Brit., 75, figs. 1, 7-12; Sacc., Syll., vol. vii., pt. I., n. 1484; Raunk., Myx. Dan., p. 62 ; Zopf, p. 168.

Lycogala affine, Berk. and Br., Ceylon Fung. (type in Herb. Berk., Kew, n. 10702).

Lycogala atropurpureum, B. and Br., Ceylon Fung., n. 735 (type in Herb. Berk., Kew, n. 10703). 
Lycogala nitidum, B. and Br., Ceylon Fung., n. 734.

Lycogala terrestre, Fr., Syst. Myc., iii., p. 83 (specimen from Fries in Herb. Berk., Kew).

Exsicc.-Cke., Fung. Brit., Ed. II., 614; Ellis, N. Amer. Fung., 334; Karst., Fung. Fenn., 287 ; Thum., Fung. Austr., 522 ; Fckl., Fung. Rhen., 1475 ; Rav., Fung. Car., 78; Mong. and Nest., n. 85 ; Kunze, Fung. Sel., 197 ; Westendorp, Crypt. Belg., 741 ; Jack, Leiner u. Sitz., 330 ; Desmaz. Cr. Fr., Ser. I., 609 ; Rab., Fung. Eur. 2140; Sydow, Myc. March., 186; Roum., Fung. Gall., 2813.

On decaying trunks, stumps, \&c. Plasmodium rose-coloured, or sometimes bright scarlet. Britain (Kew, New Forest, Rudloe, Scarboro', Carlisle, Appin, N. B., Abergavenny); Europe; U. States; Bermuda; Venezuela; Cuba; Algeria; S. Africa; Himalayas; Ceylon; Madagascar; New Guinea; W. Australia.

\section{(Rostafinski’s Synonyms.)}

Fungus coccineus, Ray Syn., ii., 336 (1690).

Fungus sanguineus, Bocc. Mus., p. 304 (1697).

Fungus non vescus, Læs. Fl. Prus., 96 (1703).

Lyycoperdon sanguineum, Rupp. Fl. Jen., 304 (1718).

Bovista miniata, Dill. Cat. Pl., 197 (1719).

Lycoperdon epidendron, Bux. Hall, p. 203 (1721); Fl. Dan.,

t. 720 ; Light. f. Fl. Scot., No. 1068; Holms. Ot., t. 31;

Bolt., t. 119, f. 1; Sow., t. 52; Purt. Midl. Fl., p. 701 ;

Rehl. Cant., p. 566: With. Arr., iv., p. 457.

Iycogala globosum, Mich., t. 95, f. 2 (1729).

Lycoperdon sanguineum, Buxb., t. 29, f. 2 (1740).

Iycoperdon sphacricum, Gled. Meth., 150 (1753).

Mucor iii. sphaericus, Gled. Meth., 161 (1753).

Mucor secundus, Schff., t. 193 (1762).

Lyjcogala scssile, Retz., Ac. Holms., 254 (1769).

Mucor lycogala, Scop. Carn., ii., 1645 (1772).

Mucor fragiformis, Schff. Bar., No. 283 (1774).

Lycoperdon variolosum, Huds. Fl. Ang., 645 (1778).

Lycoperdon epiphyllum, Huds. Fl. Ang., 645 (1778). 
Lycoperdon pysiforme, Jacq. Misc., t. 7·(1788).

Galeperdon epidendron, Wigg. Fl. Holsat, 1148 (1780).

Lycoperdon chalybeum, Batsch. El., p. 155 (1781).

Lycoperdon verrucosum, Batsch. El., p. 155 (1781).

Reticularia rosea, DC. Bullet. Phil., f. 8 A, B, C (1798).

Lycogala miniata, Pers. Obs., ii., 26 (1790); Grev. S. C. Fl.,

t. 38 ; Nees., t. 8, f. 97 ; Gray. Arr., i., 568.

Lycogala punctata, Pers, Syn., p. 158 (1801).

Lycogala plumbea, Schum. Saell., 1408 (1803).

Lycogala ferruginea, Schum. Saell., 1406 (1803).

Reticularia miniata, Poir., Ency., viii., 22 (1808).

Reticularia punctata, Poir., Ency., viii., No. 21 (1808).

Reticularia rosea, Poir., Ency., viii., No. 4.

Lycogala miniata, Johnst. Fl. Berw.

Lycogala epidendrum, Fr., S. M., iii., 80 ; Berk. Engl. Fl., v. 307 ; Cooke, Hdbk., No. 1095.

Lycogala affinis, B. and Br., Ceylon Fungi, No. 735.

\section{Lycogala conicum, Pers. .}

Plasmodiocarp sessile on a broad base, often attenuated towards the apex, hence more or less conical, shining, purple, or pale ochraceous-brown, at maturity minutely warted or scurfy; mass of spores ochraceous-olive, sometimes with a tinge of fleshcolour; tubes of capillitium numerous, originating from the inner portion of the cortex, 8-10 $\mu$ diameter, almost colourless, frequently branched and anastomosing laterally, free ends numerous, markings variable, warts or irregular raised bands more or less anastomosing or sometimes almost obsolete; spores globose, minutcly warted, 4-6 $\mu$ diameter.

Dermodium conicum, Rost., Mon., p. 284; Sacc., Syll., vii., 'pt. I., n. 1483.

Gregarious, $\cdot 5-1 \mathrm{~cm}$. or more in diameter.

From a careful examination of specimens of the present species that have been examined and named by Rostafinski, I am satisfied that the genus Dermodium is synonymous with Lycogala. In both cases the leading idea is a vein-like plasmodiocarp covered with a common cortex, the outside portion 
containing numerous cell-like aggregations of protoplasm, while the inner portion gives origin to the tubes of the capillitium which originate from the cell-like masses of protoplasm.

Rostafinski's generic diagnosis of Dermodium is altogether misleading, inasmuch as it implies that we are dealing with a single sporangium, whereas in Rostafinski's own specimens the plasmodiocarp structure is distinct. Furthermore it is very doubtful as to whether the present species is anything more than Lycogala cpidendmum. It is certain that Iycogala atropurpureum, B. and Br., and Lycogala nitidum, B. and Br., referred to the present species by Rostafinski, both belong to Lycogala epidendrum.

On rotten wood. Sweden; Germany; Ceylon.

(Rostafinski's Synonyms.)

Iyjcogala conica, Pers., Syn., 159 (1801).

Lycogala conicum, Fr., S. M., iii., 82 (1829).

Lycogala atropurpurcum, B. and Br., Ceylon Fungi, IT., n. 735 .

Lycogalc nitidum, B. and Br., Ceylon Fungi, II., n. 734.

\section{Lycogala flavo-fuscum, Rost. (fig. 123).}

Plasmodiocarp hemispherical or elongated, $3-9 \mathrm{~cm}$. diameter, cortex smooth or slightly wrinkled when dry, yellow-brown, bright chestnut-brown, or greyish-umber ; mass of spores greyishumber or with a flesh-coloured tinge; tubes of capillitium rather scanty, almost colourless, $4-5 \mu$ thick, slightly mugulose or with indistinctly raiscd bands, sparingly branched; spores globose, vcry minutcly wartcd, $5 \mu$ diameter.

Iycogala flavo-fuscum, Rost., Mon., p. 288; Cooke, Brit. Myx., p. 76 ; Sacc., Syll., no. 1485 ; Zopf, p. 167.

On stumps and trunks. Britain (King's Cliffe); Europe; United States; Ceylon.

A large species, usually solitary, distinguished from I. cpiderudrum by the smooth cortex and the scanty capillitium with thinner tubes and rudimentary ornamentation. 


\section{Lycoguīà.}

(Rostafinski's Synonyms.)

Diphtherium flavo-fuscum, Ehr., Syl., p. 27 (1818).

Reticularia flaro-fusca, Fr., S. M., iii., p. 88 (1829); B. and Br.,

Ann. Nat. Hist.; No. 591.

Reticuiaria testacea, Wallr., Fl. Germ., 209 (1833).

Lycogala ochraceum, Mass. (n. sp.).

Plasmodiocarp sessile, sub-globose, gregarious, springing from a firm, broadly effused hypothallus, ochraceous, at first smooth, becoming minutely furfuraceous; mass of spores very pale ochraeeous; capillitium scanty, tubes sparingly branched, with a few indistinetly raised bands, $5 \mu$ diameter, collapsing; spores globose, 35-4 $\mu$ diameter, minutely and sparsely verruculose.

On rotten wood. Bahia; Java. (Challenger exped.)

(Type in Herb. Berk., Kew.)

Often densely gregarious and variously angular from mutual pressure, at other times larger and scattered; from $5-2.5 \mathrm{~cm}$. diameter.

\section{Lycogala minutum, Sacc. and Paol.}

Plasmodiocarp gregarious, superficial, sessile, base narrow, globoso-depressed, $4-5 \mathrm{~mm}$. broad, smooth (not punctate), at length with crowded, very minute depressions, yellow, becoming ochraceous; hypothallus scanty, white, mucedinous; tubes of capillitium filiform, short, subsimple, hyaline; spores globose, asperulose, $3 \mu$ diameter, yellow, then colourless.

Iycugala minutum, Saccardo and Paoletti, 'Mycetes Malacenses' Atti del R. Instit. Veneto di scienze, lettere, ed arti. Tome VI., Ser. VI., p. 5, t. 5, f. 1; Sacc., Syll., n. 1486.

On fallen decorticated rotten branches. Malacca.

Apparently closely allied to Lycogala ochraceum, but distinguished by the scanty mucedinous hypothallus and in the cortex not becoming furfuraceous.

Lycogala rufo-cinnamomeum, Mass. (n. sp.).

Plasmodiocarp hemispherical, gregarious, $\cdot 5-1 \mathrm{~cm}$. diameter, surface smooth, ochraceous or greyish, sometimes with a tinge 
of red; mass of spores bright reddish-cinnamon; threads of capillitium colourless, much branched, walls smooth, not collapsing when dry, $4-5 \mu$ thick; spores globose, $10 \mu$ diamcter, rather coarsely warted.

On fragments of rotten wood lying on the ground.

South Africa.

(Type in Herb. Berk., n. 10706.)

Gregarious. Distinguished by the dense capillitium, the tubes of which have thick, smooth walls, and the large spores.

\section{Prototrichia, Rost. (emended).}

Sporangia simple or fasciculate, stipitate or sessile, thin, reflecting metallic tints, dehiscing irregularly; capillitium welldeveloped, elaters attached by one end to the basal portion of the sporangium, becoming attenuated upwards and dividing into a variable number of slender, tapering, free tips, the slender branchlets are sometimes more or less connected laterally, elaters furnished with spirals, irregular rings, or entirely smooth.

Prototrichia, Rost., Mon. App., p. 38; Cooke, Myx. Brit., p. 65 ; Sacc., Syll., vii., pt. I., p. 437 ; Mass., Revis. Trich., p. 349 .

Trichia, B. and Br., Ann. Nat. Hist., Ser. III., vol. xviii., p. 56, pl. 2., f. 4.

Cornuria, Rost., Mon., p. 289 (in part); Cooke, Myx. Brit., p. 76 (in part); Sacc., Syll., vii., pt. 1, p. 289 (in part). Alwisia, B. and Br., Journ. Linn. Soc., xiv., p. 87, t. 2, f. 6, and xv., t. 2, f. 1 ; Mass., Mon. Trich., p. 348.

Trichia, Rost, Mon., p. 246 (in part); Sacc., Syll., vii., pt. I., n. 1494 (in part).

As above defined the main features of the genus are the thin iridescent sporangial wall and the elaters attached at one end to the base of the sporangium, and becoming divided above into a variable number of tapering, free tips, the branchlets are rarely connected transversely, but never to such an extent as to suggest a network.

Distrib. Europe; Tasmania; Ceylon: 5 species. 


\section{A. Spores smooth.}

Prototrichia flagellifera, Rost. (figs. 130-132).

Sporangia scattered, globose, attenuated below to a narrow point of attachment, wall thin, smooth, copper-colour, and reflecting metallic tints; mass of capillitium and spores fleshcolour; elaters 7-9 $\mu$ broad at the base, tapering towards the apex, branching at some distance towards the point of attachment into two or three arms, each generally again divided near the apex, spirals thin, not prominent, sometimes crowded, at others distant, disappearing below the ultimate branchlets, brown, becoming colourless towards the tips; spores globose, smooth, 10-13 $\mu$ diameter.

Prototrichia flagellifer, Rost., Mon. Appendix, p. 38 (in part); Cooke, Myx. Brit., p. 65; Sacc., Syll., n. 1492 (in part); Mass., Rev. Trich., p. 350, pl. vii., f. 23.

Trichia flagellifer, B. and Br., Ann. Nat. Hist., Ser. III., vol. xviii., p. 56, pl. 2, f. 4 (no. 1143).

Dermatricha flagellifer, Cooke, MS.

(Type specimen in Herb. Berk., Kew, n. 10,905).

On dead wood. Britain (Badminton, Gloucester, Carlisle); Sweden.

Scattered, or rarely $3-5$ in a cluster, but not crowded together, 5 or a little more in diameter. A very neat species, the sporangial wall is unusually persistent, hence the plant is generally found in good condition. The smooth spores and elaters thickest at the point of attachment mark the species.

\section{Prototrichia metallica, Mass.}

Sporangia scattered, stipitate or sessile on a broad base, spherical or depressed and lenticular, smooth, shining, coppercolour with metallic tiuts; stem very short, rather thick, darker in colour than the sporangium; mass of capillitium and spores pale flesh-colour or yellowish; elaters elongato-fusiform, $6-7 \mu$ at thickest part, $300-400 \mu$ long, terminating at the apex in a 
pencil of simple or branched, cylindrical, smooth, sometimes nodulose filaments, $2 \mu$ thick, and $40-60 \mu$ long; spirals broad, flat, close; spores globose, smooth, 9-11 $\mu$ diameter.

Prototrichia metallica, Mass., Rev. Trich., p. 350, fig. 26.

Trichia metallica, B. and Br., Fl. Tasm., p. 268.

Prototrichia flagellifera, Rost., Mon. Append., p. 38 (in.part); Sacc., Syll., n. 1492 (in part).

Prototrichia clegantula, Rost., Mon. Append., p. 39, fig. 246 ; Sacc., Syll., n. 1491.

(Type in Herb. Berk., Kew, n. 10,905 a.)

On wood. Tasmania; Sweden.

Sporangia :5-1 mm. diameter. Rostafinski founded his Prototrichia clegantula on a specimen in the Berkeley Herbarium at Kew, which was sent by Fries, and marked "(Perichaena?) nova species, in Betula, Lindblad." This specimen on examination proves to be identical with Trichia metallica, B. The last-named species is given as a synonym of $P$. flagellifer, B. and $\mathrm{Br}$., by Rostafinski, the outcome of superficial examination.

\section{Prototrichia bombarda, Mass.}

Sporangia broadly fusiform or elliptical, several seated on the apex of an elongated stem, smooth, dark-brown, sometimes with a purple tinge; stem same colour, hollow, springing from a well-developed hypothallus; mass of elaters and spores brown; elaters cylindrical, $6-7 \mu$ thick, sometimes furnished with one or two swollen portions, walls thin, collapsing when dry, unbranched, with a few seattered, very rulimentary spinules, and a very indistinct open spiral, free ends obtuse, rarely attenuated and bifid; spores globose, smooth, $5-6 \mu$ diameter.

Alwisia bombarda, B. and Br., Journ. Linn. Soc., xiv., p. 87, t. 2 , f. 6 , and xv., t. 2 , f. 1.

Trichia fragilis, Rost., Mon., p. 246 (in part); Cke., Brit. Myx., p. 63 (in part); Sacc., Syll., n. 1494 (in part).

On decayed wood. Gongolla Forest; Ceylon.

(Type in Herb. Berk., Kew, n. 10921).

From 2-3 $\mathrm{mm}$. lighl, scattered. The fasciculate sporangia 
are in some specimens connate except at the tips, and then present the appearance of a single sporangium with several subacute apical lobes. The stem is somewhat contracted and wrinkled longitudinally when dry. The present plant resembles to a certain extent, when examined with a pocket-lens, fasciculate forms of Trichia fragilis, and from such superficial examination Rostafinski gave it as a synonym of the lastmentioned species. If it had been properly examined this mistake would not have been made.

\section{B. Spores warted.}

Prototrichia cúprea, Mass. (figs. 127-129).

Sporangia scattered or rather crowded, sub-globose, usually sessile on a broad base, rarely attenuated below, or with a very short distinct stem, bright copper-colour, shining, sometimes iridescent; mass of capillitium and spores reddish flesh-colour; capillitium copious, elaters $6-8 \mu$ thick at point of origin from wall of sporangium, $60-80 \mu$ long, then branching once or twice in a dichotomous manner, branches tapering upwards, 150-200 $\mu$ long, each ending in a corymbose tuft of slender, smooth, colourless filaments, $1-2 \mu$ thick, main trunk and branches brownish, with rather close, not prominent spirals; spores globose, minutely warted, 10-13 $\mu$ diameter.

Prototrichia cuprea, Mass., Rev. Trich., p. 351, pl. vii., f. 24. ('Type in Herb., Kew.)

On dead thorn. Scarborough; Carlisle.

Sporangia pure white when immature, $5-1 \mathrm{~mm}$. diameter, bright copper-colour, polished and often iridescent, especially when old and empty. Characterized by the warted spores and the slender filaments terminating the main branches of the elaters, which are not always so densely corymbose as figured in Rev. Trich., pl. vii., f. 24. A form of the present species sent by Mr. Camm from Smethwick has the elaters without a trace of spiral marking, thus approaching $P$. chamacleontina. 
Prototrichia chamaeleontina, Mass.

Sporangia spherical or spherico-depressed, attached by a narrow base, wall very thin, highly iridescent, dehiscing irregularly; capillitium well-developed, threads thick at the point of attachment, tapering upwards, often nodulose, without external markings, breaking up into several free, pointed spines that are sometimes connected by transverse bands, dingy brown; spores pale pink, globose, minutely warted, 9-11 $\mu$ diameter.

Cornuvia metallica, Rost., Mon. App., p. 35; Cooke, Myx. Brit., p. 76 ; Sacc., Syll., n.

Physarum metallicum, Berk., Mag. Zuol. and Bot., No. 29, t. 3, f. 8; Cooke, Myx. Brit., p. 16.

(Type in Herb. Berk., Kew.)

On twigs, bark, dead leaves, \&c. Britain (Clifton, Notts; Carlisle, Smethwick).

Scattered or in groups of $2-3$, about $1 \mathrm{~mm}$. diameter. Sporangial wall very iridescent, reflecting green or rosy tints, mass of spores pinkish or flesh-colour. The previous existence of a species of Prototrichic called metallica, accounts for the change of name in the present species.

\section{Ophiotheca, Curr. (emended).}

Sporangia sessile with single or double wall, frequently containing amorphous particles of lime, either regular, circular, or depressed, with circumscissile dehiscence, or aethalioid, or forming a vein-like, anastomosing plasmodiocarp; capillitium forming a loose network, attached to the wall at various points, and usually with free arms, threads with spines, warts, or short bands irregularly scattered; spores globose.

Ophiotheca, Currey, Quart. Journ. Micr. Science, vol. ii., p. 240.

Perichaena, Rost., Mon., p. 292; Cke., Brit. Myx., p. 77; Sacc., Syll., vii., 1, p. 420 (all in part).

Commvia, Rost., Mon., p. 289 ; Cke., Brit. Myx., p. 76 ; Sacc., Syll., vii., 1, p. 423 (in part). 
Closely allied on the one hand to Perichaena, and on the other to Arcyria. Differs from the latter in the sessile, much compressed sporangia often becoming aethalioid, presence of lime in the wall, and the capillitium with numerous free arms and attached to the wall at many points. From Perichaena in the threads of the capillitium being in some way ornamented. Lachnobolus differs in the stipitate sporangia.

Distrib. Europe; United States; Cuba; Ceylon. Species 9.

\section{A. Threads of capillitium spinulose.}

\section{Ophiotheca circumscissa, Curr.}

Sporangia either regular, circular, depressed, or dehiscing in an irregularly circumscissile manner, or becoming aethalioid, sinuous, and often combined into a network; wall smooth, chestnut, or brown; mass of capillitium and spores yellow; threads of capillitium 2-4 $\mu$ thick, with scattered, straight, or bent spines, $1-2 \mu$ long, combined to form an irregular network, with numerous free arms often slightly incrassated at the tips; spores globose, smooth, $8-19 \mu$ diameter.

Ophiotheca chrysosperma, Curr. Quart. Micr. Journ., v., ii, p. 240 , t. 9 , f. $1-5$.

Cormuvia circumscissa, Rost., Mon., p. 290 ; Cke., Myx. Brit., p. 76 ; Sacc., Syll., n. 1452 ; Schroeter, Kr. Fl. Schles., 108.

Cornuvia dictyocarpa, Crupa, Cosmos, Lemberg, 1866; Sacc., Syll., n. 14 ว̌3.

On bark. Britain; Germany; France; Switzerland.

\section{(Rostafinski's Synonyms.)}

Lignidium quercinum, Fr., Stirp. Femsp., 83 (1825).

Trichia circumscissa, Wallr., Fl. Cr. Germ., n. 2219 (1833).

Arcyria glomerata, Fr., Sun. Veg. Scand., 457 (1849).

Ophiotheca chrysosperma, Microsc. Journ., p. 240, t. 9, f. 1-5

(1854),

Trichia Curreyi, Crouan, 1. c., 16 (1867). 
$V a r^{\circ}$ scabra, Schroeter, Kr. Fl. Schles. (Pilze), p. 109. Threads of capillitium with rigid spines, $1-2 \mu$ long.

Silesia.

$V_{a 2}$.spinosa, Schroeter, Kr. Fl. Schles. (Pilze), p. 109. Threads of capillitium with scattered acute spines, $5-6 \mu$ long.

Silesia.

Ophiotheca Wrightii, Berk. and Rav. (fig. 197).

Sporangia circular, much depressed, dehiscing in a circumscissile manner, or becoming aethalioid and irregularly veinlike; wall bright or blackish-brown, smooth, with granules of lime inside; mass of capillitium and spores lright, decp yellon, sometimes with a flesh-coloured tinge; capillitium well developed, forming a loose, irregular network, the threads are densely and very minutely vermuculose, and in addition are furnished with numerons straight or flexuous sharp-pointed spines, 2-4 $\mu$ long; spores globose, minutely varted, 10-14 $\mu$ diameter.

Ophiothece Wrightii, Berk. and Curt., Linn. Journ., vol. x., p. $3+9$.

Cornuvia Wrightii, Rost., Mon. App., p. 36 ; Sacc., Syll., vii., 1, n. 1454 .

Exsicc.-Fung. Cub. Wrightiani, 540.

(Type in Herb. Berk., Kew, n. 10888.)

On wood. Cuba; Ceylon.

Very elosely allied to 0 . circumscissa, more especially the $V$ ar: spinose, but distinguished by the warted spores.

\section{Ophiotheca irregularis, Mass.}

Sporangia spherical, much depressed, rather convex above, usually gregarious, dehiscing in an irregularly circumscissile manner, wall bright-brown, containing lime inside; mass of eapillitium and spores bright yellow; capillitium well-developed, forming a loose net, threads $3-4 \mu$ diameter, equally covered with distinct slcuder spines ' $5-1 \mu$ long; spores globose, minutely verruculose, $9-11 \mu$ diameter. 
Perichaena irregularis, Berk. and Curt., Grev., vol. ii., p. 68; Sacc., Syll., n. 1439.

\section{On bark. Lower Carolina.}

\section{(Type in Herb. Berk., Kew.)}

Sporangia up to $1 \mathrm{~mm}$. diameter, often much crowded and consequently irregular in outline. Resembling Perichaena depressa in general appearance, but distinguished by the distinct spines uniformly and rather thickly scattered over the capillitium threads.

\section{Ophiotheca nitens, Mass.}

Sporangia single or few gathered in clusters, globose-pyriform, sessile, or with a short stem, splitting irregularly, greyish-brown with a fine violet tone of metallic lustre, $\bullet 5 \mathrm{~mm}$. broad. Wall single, almost without particles. Tubes of the capillitium long, slightly branched, by irregular enlargements fastened to the wall, unequally and very delicately spinulose, equally broad throughout, $1-1.5 \mu$ broad. Spores delicatcly spinulose, yellowish, hyaline, $10-12 \mu$ diameter.

Perichaena nitens, Raunkier, Myx. Dan., p. 107, t. 2, f. 11.

On bark of oak and fir, and on decayed leaves of pine. Denmark (Sealand, Jutland).

B. Threads of elaters with raised bands which may be short and wart-like, or combined to form rings or a nctwork.

Ophiotheca reticulata, Mass. (figs. 199, 200).

Plasmodiocarp venulose, sinuous or anastomosing to form an irregular network, dingy ochraceous-umber, wall containing numerous masses of lime inside; mass of capillitium and spores pale ochraceous-umber; capillitium scanty, threads forming a very loose network, $3-5 \mu$ thick, denscly covered with short, straight, or curved raised bands and rounded warts; spores globose, with minute, scattered warts, 13-14 $\mu$ diameter.

Licea reticulata, B. and $\mathrm{Br}$.

Perichazna reticulata, Rost., Mon. App., p. 35; Sacc., Syll., vii., 1 , n. 1442 . 
On bark. Ceylon.

(Type in Herk. Berk., Kew, n. 10852.)

Resembling in many respects Ophiotheca vermicularis, but distinguished by the very minute, scattered warts on the spores.

\section{Ophiotheca cano-flavescens, Mass.}

Sporangia gregarious, standing on a thin, yellow-grey hypothallus, globose to hemispherical, or lengthened to reniform, sessile, $\cdot 5 \mathrm{~mm}$. broad, bright yellow-grey, splitting more or less regularly with a lid. The wall contains numerous round or angular particles. The upper part of the wall, on its inner side, provided with delicate thickenings combined into a regular network; meshes of the network 5-6-gonal and $12 \mu$ diameter. Capillitium sccrecly evident, only consisting of a few, slightlybranched or quite unbranched threads of variable width, unequally wartcd, colourless, yellowish; without regard to the thickenings the tubes are $1 \cdot 5-2 \mu$ broad.

Spores golden-yellow, delicately warted, $12 \cdot 5-14 \mu$ diameter.

Perichacna cano-flavescens, Raunkier, Myx. Dan., p. 107, t. 2, fig. 10.

On bark of beech. Denmark (Lolland).

Ophiotheca vermicularis, Mass. (figs. 198, 198 a).

Sporangia circular, irregularly lobed, or venulose and anastomosing to form an irregular network; when the sporangia are circular or simply lobed there is usually a well-defined, upraised marginal portion, wall smooth with masses of lime inside, varying from flesh-colour, through brown to umber; mass of capillitium and spores flesh-colour or briglit-yellow; capillitium well-developed, attached at numerous points to wall of sporangium, combined to form a loose, irregular net, threads $3-4 \mu$ cliameter, cqually covered with numerous short, straight or eurved, sometimes branched, raised bands; sometimes a few rounded warts are intermixed, these latter now and again run out with prominent spines; spores globose, donsely and thickly covercd with small, depressed warts, $10-13 \mu$ diameter. 
Physarum vermiculare, Sz., Syn. Fung. Amer., n. 2296.

(Specimen from Schweinitz in Herb. Berk., Kew.)

Perichaena vermienlaris, Rost., Mon. App., p. 34; Sacc., Syll., vii., 1, n. 1437.

Ophiotheca umbrina, B. and C., Grev., vol. ii., p. 68 (1873). (Type in Herb. Berk., Kew.) (Not Perichaena variabilis, Rost., Mon., p. 295; Sacc., Syll., n. 1440.)

Perichaena artocreas, B. and Rav., Grev., v. ii., p. 68 (1873). (Type in Herb. Berk., Kew).

Perichacna corticalis, Rost., Mon., p. 293 (in part); Sacc., Syll., n. 1435 (in part); Cke., Myx. Brit., p. 73 (in part).

Perichaena Friesiana, Rost., Mon., 296 ; Sacc., Syll., n. 1441. On rotten wood and bark. United States.

In Schweinitz's specimen there is a clear transition shown from normal perithecia to the venulose, reticulate plasmodiocarp. In the non-venulose form the margin is uniformly raised all round. The threads covered with short raised bands, looking like warts under a low power, and the spores densely covered with depressed warts are very characteristic.

\section{Ophiotheca anomala, Mass.}

Sporangia scattered or gregarious, sessile, sub-sphaeroid, dingyochraceous, rather shining, about $1.5 \mathrm{~mm}$. diameter; threads of the capillitium 4-6 $\mu$ thick, cylindrical, ends numerous, truncate, often terminated by clavately swollen tips, with crowded raised bands arranged as circles; spores globose, smooth, dingy-ochraceous, under the microscope very pale tinge of yellow, $6-7 \mu$ diameter.

Cornuvia anomala, Karst., Myc. Fenn., 4, p. 131 ; Sacc., Syll., vii., 1,1455 .

Trichia anomalc, Karst., Not. Sällsk. pro Faun. et Flor. Fenn., ix. (1868), p. 354 .

Ophiotheca serpula, Mass.

Plasmodium venulose, yellow; mass of spores and capillitium golden-yellow; capillitium threads cylindrical, $3.3 \mu$ thick, with 
raised bands in the form of rings, $4-7-7 \mu$ ligh, combined into a net with free, more or less swollen tips; spores globose, $10 \mu$ thick, with raised bands forming a polygonal nctwork.

Arcyric serpula, Wigand, Pringsh. Jahrb., vol. iii., p. 44, t. 3, f. 18.

Cornuvia serpula, Rost., Mon., p. 289 ; Sacc., Syll., n. 1451.

On wood. Germany.

Wigand describes the spores as areolate on the surface, but judging from his figure of a spore, mag. 720 diameters, it appears that the areolation is due to raised bands combined to form a polygonal network.

Ophiotheca pallida, B. and Curt.

Sporangia flexuous, pale; threads of capillitium yellow, nodulose, minutely echinulate; spores globose, $\cdot 000+$ inch in diameter ( = about $11 \mu$ ).

Ophiotheca pallida, Berk. and Curt., Journ. Linn. Soc., vol. x., p. $350(1869)$.

On dead stems of herbaceous piants. Upper Carolina.

The flocei are very irregular in outline, and have far shorter processes than the other two species. [O. chrysosperma and $C$. Wrightii] (M. J. B.)

There is no specimen in the Berkeley Herbarium.

\section{Lachiomolus, Fries.}

Sporangia stipitate, sessile, or acthalioid, dehiscing irregularly or by, the disappearance of the upper evanescent portion of the wall; capillitium combined into a net, which is attached at numerous points to the wall of the sporangium; spores glubose.

Lachnobolus, Fries, Flor. Scand., p. 356 ; Sacc., Syll., vii., p. 433 ; Cooke, Brit. Myx., p. $7 \pm$; Zopf, p. 170.

Very closely. allied to Arcyria; in fact the ouly important point of difference consjsts in the present genus having the capillitium attached by arms at numerous points to the wall of the capillitium, hence it is not protruded elastically when 
mature as an aid in spore dispersion, a function performed by the elastic capillitium in some species of Arcyria, but not all, as in several species belonging to the last-named genus, the capillitium is in many places attached to the wall, as in $A$. chrysospora, $A$. pallidula, \&c. In Arcyria the markings on the capillitium threads are generally more developed than in Lachnobolus.

Distrib. Europe; United States. Species 4.

Lachnobolus globosus, Rost. (fig. 204).

Sporangia globose, stipitate, lower half of sporangial wall stout, persistent upper half'very thin, evancscent, yellow, becoming whitish; stem about equal in length to sporangium, straight, coloured like the sporangium, filled with large irregular angular cells; mass of capillitium and spores colour of ground ginger; capillitium dense, combined into an irregular network, attached at many points to persistent portion of sporangium, threads varying from 3-6 $\mu$ broad, closcly covered with minute warts; capillitium not elastic; spores at first sub-angular from mutual pressure, then becoming globose, but the thick wall remains slightly thickened at the angles, hence looking as if furnished with a few rudimentary warts, $6-7 \mu$ diameter.

Lachnobolus globosus, Rost., Mon., p. 283; Sacc., Syll., vii., pt. I., n. 1479.

On dry involucres of sweet chestnut.

United States.

(Specimen from Schweinitz in Herb. Berk., Kew.)

Gregarious, about $1.5 \mathrm{~mm}$. high.

(Rostafinski's Synonyms.)

Arcyria globosa, Sz., Consp. Fung. Carol., n. 400 ; Amer. Fung., n. 2340 (1822).

Craterium globosum, Fr., S. M., iii., 154 (1829).

Nassula globosa, Fr., Summ. Veg. Sc., 4556 (1849).

Var, minor, Ellis, N. Amer. Fung. Exs., n. 1397. 
Differs from the typical form in the smaller size of the sporangium and longer stem.

United States.

\section{Lachnobolus Rostafinskii, Racib.}

Sporangia stipitate, ovate-conoid, apex rounded, yellowishgrey, lower portion of sporangium with a distinet membrane, hemispherico-patelliform, the upper portion destitute of a memUrane; capillitium well-developed, forming a net adnate to the peridium by numerous branches, the upper portion with numerous free branches; threads with thin, plate-like processes forming a reticulation, varying from $4 \cdot 2-8 \cdot 2 \mu$ diameter; spores yellow, nembrane firm, smooth, $7 \cdot 5-8 \cdot 3 \mu$ diameter.

Lachnobolus Rostafinskii, Racib., Myx. Cracov., p. 12, fig. 6; Sacc., Syll., n. 1482.

Very closely allied to Laehnobolus globosus.

Poland.

Lachnobolus arcyrella, Rost.

Sporangia piriform, fulvous or almost straw-coloured, stem as long as sporanginm, or slightly shorter, sub-gilvous; capillitium not elastically extruded, forming a lax irregular network, threads $25-8: 3 \mu$ diameter, attached at many points to the sporangial wall, sometimes descending into the hollow of the stem, ormamented with numcrous obtuse, small warts; spores smooth, 7-8 $\mu$ diameter.

Lachnobolnes arcyrella, Rost., Mon., p. 431 ; Sacc., Syll., vii., 1, n. 1480 .

Jutland.

Lachnobolus incarnatus, Schroet.

Sporangia when free globose or elongated, sessile, usually clustered and forming a plasmodiocarp, wall thin, brittle, pinkish, becoming brown, smooth, shining, dehiscing irregularly; mass of spores flesh-colour; threads of capillitium combined to form a dense net; 4-5 $\mu$ thick, ornomented with warts and short, 
irregular bands, incrassated at the nodes; spores globose, smooth, 6-8 $\mu$ diameter.

Lachnobolus incarnatus, Schroeter, Kr. Fl. Schles., 110 ; Sacc., Syll., vii., 1, n. 1478.

Lachnobolus circinans, Rost., Mon., p. 281.

Lachnobolus congesta, B. and Br., Ann. Nat. Hist., n. 1604, t. 9, f. 2 ; Cke., Myx. Brit., p. 74; Sacc., Syll., n. 1481.

On rotten wood, especially pine. Britain (King's Cliffe); Germany; Switzerland; Lapland.

\section{(Rostafinski's Synonyms.)}

Arcyria circinans, Fr., Stirp. Femsj., p. 83 ; Fr., S. M., iii., p. 177 (1825).

Lachnobolus circinans, Fr., Fl. Scan., 356 (1835).

Lachnobolus Sauteri, Rost., in Fckl. Symb., 2, p. 76 (1873).

Licca incarnata, A. and S., Consp., 109, t. 10, f. 6 (1805).

Lycogala incarnatum, Swrtz, Vet. Ac. Handl., 112 (1815).

Perichaena incarnata, Fr., S. M., iii., p. 193 (1829).

Lycopcrdon pinetum, Batsch., Elench., p. 155, n. 29 (1783).

Physarum congestum, Somf., Fl. Lap., p. 241 (1825).

Pcrichacna congesta, Fr., S. M., iii., p. 192 (1829).

Licca congesta, Wllr., Fl. Cr. Germ., n. 2108 (1833).

\section{Heterotrí́chia, Mass. (Nov. Gon.).}

Sporangia densely crowded or scattered, stipitate; wall single, thin, upper portion disappearing at maturity, leaving the basal portion as a calyculus; stem filled with large, thick-walled cells that are sub-angular from mutual pressure; these become smaller upwards, and pass gradually into normal spores; capillitium free from wall of sporangium, its lower branches passing between the cells filling the stem, central portion composed of very thin tubes anastomosing to form a loose, irregular network; towards 
the periphery the branches become many times thicker, and form a small-meshed regulır network, furnished with numerous stout, acute, free tips; the free tips are simple, or once or twice furcate; the entire capillitium is protruded elastically during dehiscence; columella absent; spores globose.

Distinguished from Arcyria, its nearest ally, by the very numerous free, pointed, simple or branched spines springing from the tubes of the stont peripheral portion of the capillitium, the meshes of which are much more uniform in size and shape than in Arcyria. The present genus agrees with Ophiotheca in the presence of numerous free arms on the capillitium, but in the last-named genus the free ends are not attenuated at the point, but usually inflated, and furthermore the tubes of the capillitium are of equal thickness throughout, and not of two distinct types as in Hetcrotrichic.

Heterotrichia Gabriellae, Mass. (n. sp.) (figs. 205-207).

Sporangia densely crowded, becoming scattered towards the margin of the cluster, cylindric-ovate, wall thin, smooth, even, at first red, becoming yellowish-brown at maturity, upper portion disappearing, leaving a small calyculus; stem much shorter than sporangium, thin, filled with large cells; mass of capillitium and spores yellowish-brown; threads of central portion of capillitium about $1.5 \mu$ thick, with slightly raised rings or short bands partly encircling the tube, almost colourless, threads of peripheral portion bright-yellow, $j-6 \mu$ thick, forming an even network, free arms of equal thickness to tubes of network, 40-60 $\mu$ long; every part densely and uniformly covered with warts or short bands, a few scattered elliptical swellings are present on the tubes and spines; spores globose, smooth, $7-8 \mu$ diameter.

On wood. South Carolina.

(Type in Herb.,' Kew.)

Sent to Dr. Cooke by the late H. W. Ravenal, accompanied by the following note:- "Arcyria Gabriellae, n. sp. Primary state red, becoming fuscous, closely congregated, elongated, 
stipitate, peridia circumscised, upper part fugacious, spores reddish fuscous. April 1850. S. C., H. W. R."

The species was considered by Cooke to be Arcyria bicolor, Berk.

\section{Arcyria, Hill (emended).}

Sporangia regular, plasmodiocarp, or aethalioid, wall single, dehiscing irregularly or in a circumscissile manner, basal portion persistent, columella absent; stem usually filled with large cells which become smaller upwards and gradually pass into normal spores; capillitium dense, usually becoming elastically elongated and protruding during dehiscence, free, or the basal threads attached to the inside of the stem, or attached at, several points to the lower, persistent portion of the sporangial wall, threads combined to form a dense network with or without free ends, ornamentation in the form of continuous ridges arranged in a spiral, or prominent, plate-like half-rings or spines arranged in a very open spiral, or wart-like spines scattered equally over the entire surface of the threads.

Arcyria, Rost., Mon., p. 270 ; Cke., Myx. Brit., p. 69 ; Sacc., Syll., vii., p. 425.

Hemiarcyria, Rost., Mon., p. 261 ; Cke., Myx. Brit., p. 67 ; Mass., Mon. Trich., p. 27; Sacc., Syll., vii., 1, p. 446.

The genus Hemiarcyria was founded by Rostafinski on those species of Arcyria having continuous ridges arranged in a spiral manner on the threads, as in the genus Trichia, and remodelled Arcyria to include all those species having the threads ornamented in any other fashion than by spirally arranged ridges. It is an open question as to whether ornamentation of the capillitium threads is of generic value even if constant, as supposed by Rostafinski, but such is certainly not the case; the two extreme characteristics overlap and are combined in several species. In some species of Hemiarcyria the spiral ridges are accompanied by numerous spines, as in H. rubiformis and $H$. serpula, whereas in H. melanopeziza, a Brazilian species, the spines are abundant, and the spiral ridges present, but shadowy in some individuals and entirely absent in others, consequently 
in the same species, and sometimes in different portions of the same individual we meet with the features of the two supposed genera. Finally in Arcyria, in Rostafinski's sense, the markings, whether in the form of prominent, ridge-like half-rings or spines, are arranged in a spiral manner, and may be looked upon as the remaining portions of continuous spiral ridges, the greater portions of which are obsolete. For the above reasons the two genera proposed by Rostafinski have been merged into one under the older name of Arcyria.

Distrib. Europe; S. Africa; India; E. Indies; Ceylon; Australia; N. Zealand; Tasmania; United States; S. America. Species 38.

A. Eu-Arcyria. Threads of capillitium without continuons spirally arranged ridges.

* Spores smooth.

Arcyria punicea, Rost. (figs. 242-244).

Sporangia globose, ovate or elliptical, stipitate, wall vermilion, sometimes with a brownish or purple tinge, rarely yellowishbrown; stem slender, about equal in length to sporangium or longer, same colour, filled with large cells, expanding at the base into a hypothallus, capillitium and mass of spores dullvermilion, crimson-lake, brownish, or sometimes yellow-brown; capillitium dense, protruding elastically, attached at many points to the firm, plicate, persistent basal portion of the sporangial wall, threads combined to form a very irregular network with or without free ends, furnished with prominent half-rings arranged in a very open spiral, remainder smooth; spores globose, smooth, pink, or pale-brown, $6-8 \mu$ diameter.

Arcyria punicea, Rost., Mon., p. 268, figs. 190, 192, 197 ; Cke., Myx. Brit., p. 69, figs. 190, 192, 197 ; Sacc., Syll., vii., 1, n. 1457; Zopf, p. 165.

Arcyria vernicosa, Rost., Mon. Supp., p. 69.

Exsicc.-Jack, Leiner u. Sitz., n. 613; Cke., Fung. Brit., 613; ed. II., 520 ; Syd., Myc. March., 915 ; Rab., Fung. Eur., 1914; 
Fckl., F. Rhen., 1441; Karsten, Fung. Fenn., 378; Ellis, N. Amer. Fung., 1114; Klotzsch, Herb. Myc., 671 ; Rav., Fung. Car., 80 ; Wentendorp, Herb. Crypt. Belg., 81; Desm., Cr. Fr., Ser. I., 1510.

On rotten wood. . Britain (Poole, Woolwich, Kew, Chester, Scarboro', Carlisle, Aboyne, N. B.) ; Europe; S. Africa ; Ceylon; S. Australia; New Zealand; United States; Canada; Brazil.

Gregarious, often springing from a common hypothallus, $1.5-3 \mathrm{~mm}$. high. Distinguished by the capillitium being attached to the cup-like permanent portion of the sporangial wall, and the prominent, flattened half-rings arranged in a loose spiral on the threads of the capillitium, which are otherwise smootl. The threads of the capillitium are often compressed or triangular, but not unfrequently terete.

\section{(Rostafinski’s Synonyms.)}

Clathroides purpureum, Mich., t. 94, f. 1, 1. c. (1729); Hall., pl. 1, f. 6 (1742).

Clathrus pediculatus, Guett., Obs. 1, 16 (1747).

Arcyria pedicula, Hill, p. 47 (1751).

Clathrus denudatus, Linn., Sp. Pl., 1179 (1753).

T'richia, Hall, No. 2164, t. 48, f. 6 (1768).

Mucor clathroides, Scop. Carr., ii., 492 (1772).

Mucor pyriformis, Leers. Fl. Herb., 1135 (1775).

Clathrus pedunculatus, Batsch. Fl., p. 141 (1783).

Lycoperdon rufum, Dicks Cry., fasc. i., p. 25 (1785).

Stemonitis denudata, Rehl. Fl. Cant. (1786).

Embolus crocatus, Batsch., t. 30, f. 176 (1786).

Stemonitis crocata, Willd. Fl. Ber., 1189 (1787).

Stemonitis coccinea, Roth. Fl. Germ., i., 548 (1788).

Trichia denudata, Vill. Fl. Dauph., 1060 (1789) ; Purt. Mid.

Fl., t. 24, f. 2 ; Sow., t. 49.

Trichia graniformis, Hoffm. V. Cr., i., p. 3 (1490).

Trichia cinnabaris, Bull., t. 502, fig. 1, b. c. (1791).

Stemonitis crocea, Gmel. Sys., 1467 (1791).

Trichia mufa, With. Arr., iii., p. 478 (1795). 
Arcyria punicca, Pers. Disp., p. 10 (1797); Eng. Fl., v., 318;

Cooke, Hdbk., No. 1170 ; Fung. Brit., ii., 520.

Trichia purpurca, Schum. Saell., 1472 (1803).

Arcyria rnfa, Schum. Saell., 1486 (1803).

Arcyric melanoccphala, Schum. Saell., 1484 (1803).

Arcyria conjugata, Schum. Saell., 1485 (1803),

Arcyria cincta, Schum. Saell., 1480 (1803).

Arcyrica cylindrica, Schum. Saell., 1486 (1803).

Trichia cinnabaris, DC. Fl. Fr., No. 688 (1805).

Arcyria fusca, Fr. Gast., p. 17 (1818).

Areyrice vernicosa, Rost., Mon. Supp., p. 36.

Arcyria punicea. Var. cribroides, Raunk.

The inner meshes equal and of ordinary width; on the surface of the capillitium, on the contrary, groups of very small and single layers succeed each other alternately.

Raunk., Myx. Dan., p. 108, t. 3, f. 12.

Jutland.

Arcyria ferruginea, Rost. (figs. 250-253).

Sporangii globose or ovate, sometimes deformed, stipitate, clull vermilion or rusty-red, sometimes pale reddish-pink; stem thin, length variable, usually short, filled with large cells; mass of capillitium and spores brick-red, brownish, sometimes ochraceous; capillitium becoming elastically protruded, threads combined to form a dense, irregular network, more or less acutely triangulur, one sulle with parallel mojecting vidges, the two others with a finc, irreguler network; spores globose, smooth, $9-11 \mu$ diameter.

Arcyria fcrruginea, Rost., Mon., p. 280, fig. 194; Cke., Myx. Brit., p. 7:3, fig. 194; Sace., Syll., vii., 1, n. 1470.

Areyria intricata, Rost., Mon. Suppl., p. 72.

Exisicc.-Fuckel, Fung. Rhen., n. 1444.

On rotten wood. Britain (Hampstead, Carlisle, Scarboro'); Europe; United States; Ceylon.

Distinguished amongst the red species of Arcyria by the 
portion of the capillitium threads not occupied by the prominent ridges being ornamented with a delicate network of slightly raised lines.

\section{(Rostafinski's Synonyms.)}

Arcyria ferruginea, Sauter., p. 316 (1811). Arcyria lateritia, DeBy. Mycet., 24 (1859). Arcyria ferruginea, Fckl. Sym., p. 337 (1869); Berk. and Br., Ann. Nat. Hist., No. 1603; Grevillea, v., p. 13.

\section{- Arcyria incarnata, Rost.}

Sporangia crowded, ovate or sub-globose, stem very short or absent, wall reddish, often with a brown or yellow tinge; mass of spores and capillitium flesh-colour, rosy, or reddish-brown, sometimes ochraceous; capillitium attached to the apex of stem wall, and with very few attachments to basal portion of thin, sporangial wall, threads combined to form a dense, elastically protruding network, with many free, flattened, or swollen spinose tips, markings in the form of half-rings or spines, or a mixture of the two arranged in a loose spiral, and, mixed with small, spinose warts, there are frequent swellings in the length of the threads; spores globose, smooth, pinkish or tinged with ochre, $6-8 \mu$ diameter.

Arcyria incarnata, Rost., Mon., p. 275, figs. 187, 199 ; Cooke, Myx. Brit., p. 71, figs. 187, 199.

Arcyria adnata, Rost., Mon. Supp., p. 72.

Exsicc.-Fuckel, Fung. Khen., 1442.

On rotten wood and bark. Britain (Lyndhurst, Kew, King's Cliffe, Norths, Carlisle, Aboyne, N. B.); Europe; United States ; India; Ceylon.

Usually crowded, sub-sessile, $1 \cdot 5-2 \mathrm{~mm}$. high. The wall of the sporangium is thinner, and the permanent base little or not at all longitudinally ribbed; the capillitium threads are generally round, but sometimes compressed. Closely allied to A. punicea, of which the present is perhaps only a variety; intermediate stages between the two are not wanting. 
(Rostafinski's Synonyms.)

Clathroides purpureum, Mich., t. 94, f. 2 (1729).

Arcyria sessilis, Hill, p. 47 (1751).

Clathrus ramosus, a., Retz. Vet. Hand., 253 (1769).

Iycoperdon hypoxylon, Pallas., ii., 503 (1771).

Clathrus adnatus, Batsch., p. 141 (1783).

Stcmonitis trichia, Roth. Fl. Germ., 1., 549 (1788),

Stemonitis lilacina, Schr., Fl. Bav., ii., 1784 (1789).

Stemonitis incarnata, Pers., in Gmel., 1467 (1791).

Trichin cinnabaris, Bull., t. 502, f. 1, D (1791).

Arcyria incarnata, Pers., Obs., t. 5, f. 4, 5 (1796); Eng. Fl.,

v., 318; Cke., Hdbk., 1171.

Stemonitis carnea, Trent., 222 (1797).

Stcnionitis globosa, Trent., p. 222 (1797).

Trichia flexussa, Schum. Saell., 1465 (1803).

Arcyria lilacina, Schum. Saell., 1476 (1803).

Arcyria carnca, Schum. Saell., 1477 (1803).

Arcyria dentate, Schum. Saell., 1478 (1803).

Arcyria rosea, Spr.

Arcyria incarnata, $\beta$ flexuosa, Fr., S. MI., iii., 179 (1829).

Arcyria nutans, $\beta$ exiguc, Bong., in Weinm., 609 (1836).

Arcyria flexuosa, Rabh., Fl. Cry., 2158 (1844).

\section{Arcyria irregularis, Racib.}

Sporangia pinkish-red, stipitate; stem up to $5 \mathrm{~mm}$. high, filled with large, colourless cells; calyculus homispherical, mombrane minutely warted; capillitium forming an irregular net, meshes of variable size; threads flattened, margin undulate, from $4.5-9.1 \mu$ wide, $2.5-4.5$ thick, threads cverywutere densely covered with irregular obtuse cones $0.8-1.5 \mu$ broad, for the most part elongated; spores $7-7.5 \mu$ diameter, membrane firm, smooth, alınost colourless.

Arcyria irregularis, Racib., Myx. Crac., p. 15, fig. 10; Sacc., Syll., vii., 1, n. 1466.

Poland. 


\section{Arcyria Erstedtii, Rost.}

Sporangia ovate, in the typical form, stipitate, stem shorter than sporangium, firm, erect; like the sporangium, dirty brown; mass of capillitium and spores brown, often with a red tinge; capillitium forming a rather dense net, threads cylindrical, 3-5 $\mu$ diameter, with scattered, elliptical, sucollen portions, sparingly and equally covercd with slender spincs of various lengths; spores smooth, 8-10 $\mu$ diameter.

Areyria Erstedtii, Rost., Mon., p. 278, fig. 196; Sacc., Syll., vii., 1, n. 1468; Raunk., Myx. Dan., p. 60, t. 3, f, 1; Cke., Myx. Brit., fig. 196.

On wood. Britain (Burnham Beeches, Bucks); Denmark; Russia.

Characterized by the net, without free arms, having its threads swollen at intervals, and sparingly and equally covered with slender spines of variable length, the longest about equal to diameter of thread.

\section{Arcyria umbrina, Schum.}

Sporangia single or gregarious, on a thin, shining hypothallus, ovate, stipitate. Receptacle on the inner side provided with a network of delicate thickenings. Stem brownish-black, longer than the sporangium. After dehiscence of the sporangium the capillitium enlarges itself but slightly. Capillitium and the mass of spores ochre-brown. Tubes of net of the capillitium with thickenings in the form of half-rings encircling the thread in a spiral, without regard to the thickenings $2 \cdot 5-3 \mu$ broad. Spores smooth, $5-7 \mu$ diameter.

Arcyria umbrina, Schum., t. 3, f. 5. Schumacher : Fl. Saell., No. 1479; Fl. Dan. Tab., 1975, fig. 1; Raunk., Myx. Dan., p. $108, t, 3$, f. 8 .

On rotten stumps. Summer; autumn. Near Copenhagen.

When comparing the two Arcyria-species delineated in the Flora Danica, 1975, figs. 1 and 2, with the descriptions of them, it will be seen that the text to fig. 1 in reality belongs 
to fig. 2, which no doubt is Areyria cinerea, what also may be seen by comparison of this figure with the authentic figure in Bulliard's Hist. des champ., \&c., Tab., 447, fig. 3.

This error is tơ be found in all authors who have cited Tabula 1975 of Fl. Dan. I beg to observe that I follow the figure no. I. of the Tabula and correct the text according to this, consequently for $A$. cinerea I have cited Fl. Dan. Tab. 1795, fig. 2.

Fig. 1 on the Tabula-fig. 2 in the text-Arcyria umbrina, Schum., is bitherto quoted as synonymous with $A$. pomiformis, Roth., but I think they are rather different both in their shape and in their colour.

On a rotten stump near Copenhagen I have fonnd the above described Areyria, which throughout harmonizes with the figure named and with Schumacher's description of his A. umbrina. This species I therefore believe to have again found. As may be seen from the description, $A$. umbrina is in the thickenings on the tubes of the capillitium very different from $A$. pomiformis, and more connected with $A$. punicea. (Raunkier, in Myx. Dan.)

From the above it appears that Raunkier considers he has collected the species intended by Schumacher. It will be noted, however, that no type specimens are factors in the determination, but only figures.

\section{Arcyria insignis, Kalchb. and Cke.}

Sporangia scattered, very minute, not more than $5 \mathrm{~mm}$. high, cylindric-ovate, rosy or vermilion, upper portion falling away, calyculus minute; stem half as long as sporangium, similarly coloured, filled with large, globose, coloured cells which pass into normal spores at the apex; capillitium dense, protruded elastically, threads cylindrical, thick-walled, combined into an irregular network; everywhere densely and equally covered with stout, acute spines about $1 \mu$ high; spines not connected into a network at the base; spores globose, smooth, $11-12 \mu$ diameter.

Arcyria insignis, Kalchbr. and Cke., Grev. x., p. 143; Sacc., Syll., no. 1475.

On rotten wood. S. Africa. 
(Type in Herb., Kew.)

Distinguished amongst the red species by the cylindrical threads of the capillitium being equally and densely covered with short spine-like warts or very short bands.

\section{Arcyria fusca, Fries.}

Every part umber-brown, sometimes with a tinge of olive; sporangia stipitate, globose or very broadly elliptical; basal portion remaining as a calyculus; stem 3-4 times as long as sporangium, very thin, equal, filled with large cells that become smaller upwards; capillitium protruded elastically, attached to base of sporangium, the threads passing down between the cells of the upper portion of the stem, threads round, combined to form a dense network, with a single row of warts or vcry short plates arranged in a very open spiral; spores globose, smooth, 7-9 $\mu$ diameter.

Arcylia fusca, Fries, Gast., p. 17.

Arcyria punicea, Rost., Mon., p. 268; Cke., Myx. Brit., p. 69 ; Sacc., Syll., vii., 1, no. 1457 (all in part).

Exsicc.-Fuckel, Fung. Rhen., 1443.

(Specimen from Fries in Herb. Berk.)

On wood. Britain (Batheaston); Sweden; Germany.

Gregarious, 3-4 $\mathrm{mm}$. high. Considered by Rostafinski as synonymous with Arcyria punicea, from which it differs in the ornamentation of the threads, consisting of spines or short flattened plates not occupying more than $\frac{1}{4}$ diameter of thread, long, thin stem, colour, \&c.

\section{Arcyria versicolor, Phill.}

Sporangia elongato-pyriform or clavate, often attenuated downwards into a short, thin, weak stem; wall of sporangium smooth, polished, varying from bright clear yellow to dark olive; dehiscing irregularly, basal portion persistent; springing gregariously from a well-developed hypothallus; mass of capillitium and spores clear yellow to dusky olive; capillitium attached only to inner surface of stem-like base of sporangium; forming 
a dense, irregular network, protruded elastically; threads equally covercd in every part with short, varionsly curved, and froquently anastomosing, slightly raised bands; sometimes a more or less perfect ring occurs; spores globose, smooth, 8-10 $\mu$ diameter.

Arcyria versicolor, Phillips, in herb.

Arcyria versicolor, Phill., Grev., v., p. 115, t. 88, f. 8, a-e; Sacc., Syll., vii., 1, n. 1473.

Arcyria vitellina, Phill., Grev., v., p. 115, t. 88, f. 7, a-e; Sacc., Syll., n. 1474 .

On trunks. California.

A beautiful species, 3-3·5 $\mathrm{mm}$. high. Variable in colour, but constant in all important characters. I am indebted to Mr. Phillips for an opportunity of examining the type specimens.

Arcyria nutans, Rost. (figs. 140, 141).

Sporangia cylindrical, sometimes ovate, vcry shortly stipitate, wall dingy yellow; stem same colour, filled with large cells; capillitium and mass of spores pale opaque yellow; capillitium clastically protruded, clongated, drooping, threads combined to form a dense, irregular network, thickenings in the form of prominent half-rings, often with projecting spines arranged in a diffuse spiral, the remainder covered with a fine, irregular network; spores globose, pale yellow, smooth, $7-8 \mu$ diameter.

Arcyria nutans, Rost., Mon., p. 277 ; Cke., Myx. Brit., p. 72.

Exsicc.-Fuckel, Fung. Rhen., n. 1439.

On rotten wood and bark. Britain (Kew, Scarboro', Carlisle); Europe; United States.

Scattered or gregarious, $1 \cdot 5-2 \mathrm{~mm}$. high. Somewhat resembling $A$. cinerea, but distinguished by the short stem, the elastically protruded, very long, drooping capillitium, which is usually the colour of ground ginger, but sometimes tinged with brown, and more especially by the portion of the capillitium threads not occupied by the half-rings being ornamented with a fine network of slightly raised lines. 


\section{(Rostafinski's Synonyms.)}

Clathroides flavescens, Mich., p. 214 (1729).

Clathroides longissimum, Hall, p. 10 (1742).

Clathrus ramosus, $\beta$. Retz. Vet. Handl., 253 (1769).

Trichia nutans, Bull., t. 502, f. 3 (1798); Sow., t. 260.

Stemonitis nutans, Gmel., Sys.; 1467 (1791).

Arcyria flava, Pers. Obs., i., 85 (1796); Grev., t. 309.

Stemonitcs amaena, Trent., p. 222 (1797).

Trichia elongata, Schum. Saell., 1464 (1803).

Arcyric alutacea, Schum. Saell., 1474 (1803).

Arcyria nutans, Grev. Fl. Ed., p. 455 (1824); Eng. Fl., v.,

319 ; Cooke, Hdbki:; No. 1173.

Arcyria pallens, Wallr. in litt.

Arcyrica straminea, Wallr. Crypt. Germ., 2232 (1833).

Arcyria nutans, c, minor, Bong., in Weinm, p. 609 (1836).

Arcyria cinera, Mass. (figs. 137-139, and 248, 249).

Sporangia varying from globose to cylindrical, stipitate, simple or digitato-fasciculate on a common stem, wall thin, smooth, grey, or yellowish, cup-like base persistent after dehiscence; stem slender, about equal in length to sporangium or longer, straight, colour of sporangium, filled with large cells that become smaller upwards; mass of capillitium and spores yellowish-grey or grey; capillitium dense, protruding clastically, and remaining erect, threads combined to form an irregular network, variable in thickness, often smooth or minutely warted towards the base, the remainder equally covered with close-set short spines, or half-rings or spines arranged in a diffuse spiral; spores globose, smooth, rarely minutely granular, $7-9 \mu$ diameter. Arcyria cinerca, Rost., Mon., p. 272, figs. 182-185, 193; Ćooke, Myx. Brit., p. 71, figs. 182-185, 193; Sacc., Syll., vii., 1, n. 1459.

Arcyria pomiformis, Rost., Mon., p. 271 ; Cke., Myx. Brit., p. 70.

Arcyria stricta, Rost., Mon. Supp., p. 71. 
Arcyria Friesii, B. and Br., Ann. Nat. Hist., n. 1602 (type in Herb. Berk., Kew); Cke., Myx. Brit., p. 71, figs. 251 and 259. Exsicc.-Fuckel, Fung. Rhen., 1440 ; Sydow, Myc. March., n. 1499; Rab., Fung. Eur., 369 ; Ellis, N. Amer. Fung., 1115.

On wood and bark. A variable species, from $1.5-4 \mathrm{~mm}$. high, the capillitium remains erect after expansion. In the fasciculate form the sporangia are cylindrical and elongated, 2-8 springing from a long, slender stem.

Britain (Lyndhurst, Swansea, Kew, Bulmer, Scarboro', Carlisle, Appin, N.B.); Europe ; United States; Brazil; Venezuela; S. Africa; Himalayas; Ceylon.

(Rostafinski's Synonyms.)

(Under A. cinerea.)

Cluthrus recutitus, Linn. Sp., 1649 (1764).

Trichia, Hall., No. 2166 (1768).

Trichia cinerea, Bull., t. 477, f. 3 (1791).

Stcmonitis recutita, Gmel. Sys., 1467 (1791).

Stemonitis cincrea, Gmel. Sys., 1467 (1791).

Arcyric albida, Pers. Disp., t. 1, f. 2 (1797).

Stcmonitis glauca, Trent., p. 221 (1797).

Arcyric cinerca, Schum. Saell., 1480 (1803); Fl. Dan., t. 1975,

f. 1 ; Eng. Fl., v., 31s; Cooke, Hdbk., No. 1172.

Trichia cernca, Wall. in litt.

Areyric carnea, Wall. Fl. Germ., 2234 (1833).

Areysia trichioides, Corda Ic., ii., f. 86 (1838).

Stemonitis grizea, Opiz. in Lotos, 215 (1855).

Areyria pallida, B. and C. Grev. (1873), No. 365.

Arcyric stricta, Rost., Mon. Supp., p. 36.

\section{(Under A. pomiformis.)}

Stemonitis pomiformis, Roth. Fl. Germ., i., 548 (1788).

Stemonitis ochrolcuca, Trent. in Roth., 221 (1797).

Stcmonitis lutca, Trent., 221 (1797).

Arcyria umbrince, Schum. Saell., 1479 (1803); Berk. Ann. N.

Hist., No. 389 ; Cookc, Hdbk., No. 1174. 
Arcyria silacea, Ditm., t. 8 (1817).

Arcyria ochroleuca, Fr. S. M., iii., 181 (1829); Berk. Ann. N.

Hist., No. 115 ; Cooke, Hdbk., No. 1175.

Arcyria lutea, Schwz. Fung. Car., 2339 (1831).

Arcyria globosa, Weinm, teste Fr.

Stemonitis ochracea, Opiz. herb.

Arcyria cinerea. Var. cribroides, Raunk.

Tubes of the capillitium broader than those of the type species, the inner meshes equal and of ordinary width, on the surface of the capillitium, on the contrary, groups of very small meshes and single larger succeed each other alternately.

Raunk., Myx. Dan., p. 107.

On decayed branches of fir. Denmark.

\section{Arcyria digitata, Rost.}

Scattered or gregarious, several sporangia, 3-7, fasciculate on a common stem; sporangia shortly cylindrical, apex obtuse, basal cup-like portion persistent; mass of capillitium and spores pale opaque greyish-yellow, or with an ochraceous tinge; stem elongated, equal, rather slender, expanded at the base into a circular hypothallus; capillitium dense, becoming very much elongated after dehiscence, threads forming a network, meshes very irregular in size; here and there minutely warted, varying in thickness; spores globose, smooth, 7-10 $\mu$ diameter.

Arcyria digitata, Rost., Mon., p. 274; Sacc., Syll., vii., 1 n. 1460 .

Stemonitis digitata, Sz., Syn. Amer., n. 2350.

(Specimen from Schweinitz in Hb. Berk.)

Arcyria Leprieurii, Mont., Ann. Sci. Nat., Ser. IV., vol. iii., p. 141. (Type in Herb. Mus., Paris.)

Arcyria bicolor, B. and C., Juurn. Linn. Soc., vol. x., p. 349.

(Type in Herb. Berk.)

Exsicc.-Fung. Cub. Wrightian., 542 (as Arcyria bicolor, B. and C.).

On wood and bark. Cuba; U. States; Cayenne. 
From 3-4 mm. high; several sporangia fasciculate on a common stem, rarely simple. Closely allied to Areyria cinerea, differing in the larger size of the sporangia. Sometimes the capillitium and spores are brownish or red.

\section{(Rostafinski's Synonyms.)}

Stemonitis digitata, Sz., Amer., f., n. 2350 (1834).

Arcyria Leprieurii, Mont., Ann. Sci. Nat., v. iii., p. 141, no. 603 (1855).

\section{Arcyria Cookei, Mass. (n. sp.).}

Gregarious; evcry part bluish-grey; sporangia narrowly cylindrical, elongated, wall very thin except the basal portion which persists as a shallow calyculus; stem erect, elongated, very slender, equal, filled with irregular lumps of organic matter; capillitium dense, becoming protruded elastically during dehiscence and remaining erect, innermost threads very thin, $1 \cdot 5-2 \mu$ smooth, combined to form a very large-meshed, irregular network, outer threads 4-5 $\mu$ thick, dcnscly and uniformly corercd with minute warts, forming a small-meshed network; spores globose, smooth, $8-9 \mu$ diameter.

On wood. Brazil.

\section{(Type in Herb., Kew.)}

From $35-4 \mathrm{~mm}$. high; stem about equal in length to sporangium. Placed by Dr. Cooke along with Arcyria einerca, from which it differs in the thin, elongated sporangium, the details of the capillitium, and in the thin long stem being filled with amorphous lumps of organic matter.

\section{Arcyria dictyonema, Rost.}

Sporangia ovate, stipitate; stems springing in clusters from the substratum, capillitium not very much divided, threads cylindrical, wilth variable, generally $3.5 \mu$ thick, sub-equally covered with an elevated network, the bands of which are spinulose, spines $1-2 \mu$ hiyh; spores smooth, $9-10 \mu$ diameter. 
Arcyria dictyonema, Rost., Mon., p. 279, fig. 195; Cke., Myx. Brit., fig. 195 ; Sacc., Syll., vii., 1, n. 1469.

Russia; Germany.

Appears to approach very closely some forms of $A$. cinerea and $A$. nutans.

(Rostafinski's Synonyms.)

Arcyria nutans, (a) sordide ochracea, Bong., in Wein., l. c., p. 609 (1836).

Arcyria ochracea, D. By., MS.

Arcyria cinnamomea, Kaulfuss, MS.

\section{Arcyria Hariotii, Mass. (n. sp.).}

Gregarious or much crowded and irregularly polygonal from mutual pressure, depressed, sessile on a broad base, sporangial wall primrose-yellow, smooth, shining, capillitium and mass of spores dingy yellow; threads of capillitium $6-8 \mu$ diameter, forming a dense, irregular net, uniformly and densely covercd with minute warts; spores globose, wall thick, smooth, $7-9 \mu$ diameter.

France. Communicated by M. Hariot of the Paris Museum.

On decayed wood. About $5 \mathrm{~mm}$. diameter, superficially closely resembling Oligonema nitens. Agrees in the smooth spores, dense capillitium, and polished sporangium with Arcyria versicolor, but in the latter the sporangium is clavate or elongatopyriform, and the markings of the capillitium consist of short irregularly arranged bands.

\section{Arcyria aurantiaca, Raunk.}

Sporangia gregarious, ovate, or shortly cylindrical, stipitate; stem same length or shorter than sporangium. Thickenings on the inner side of the receptacle, in the form of fine warts; wall, capillitium, and mass of spores brick-red to orange. Tubes of the capillitium with irregularly connected, close-standing, ring-like thickenings, $5-7 \mu$ broad; spores smooth, 10-11 $\mu$ diameter. 
Arcyria aurantiaca, Raunk., Myx. Dan., p. 109, t. 3, figs. 4, and $9-11$.

On rotten wood. Denmark.

From the above description it is difficult to indicate either the prominent features of the species intended, or its affinity with other species.

** Spores warted.

Arcyria similis, Racib.

Sporangia shortly stipitate, cherry-coloured; threads of capillitium thick-walled, $4 \cdot 2-5-8 \mu$ broad, cylindrical or a little compressed, everywhere with plate-elevations; plates generally in the form of half-rings not arranged in a regular spiral manner, but irregularly, or overlapping, or in spirals irregularly broken up; spores $8.3 \mu$ diameter, almost colourless, wall thin, distinctly vcrruculose.

Arcyria similis, Racib., Myx. Crac., p. 13, f. 8; Sacc., Syll., n. 1462.

Poland.

\section{Arcyria Raciborsckii, Berlese.}

Sporangia stipitate, stem filled with cells; calyculus hemispherical, membrane thin, reddish, densely covered on the inner surface with very short, acuminate warts; capillitium at the nodes and often also on the internodes inflated into globose vesicles, forming a loose net; threads of lower portion of the capillitiun flattened, one margin with incrassated teeth, remainder of threads smooth, the remainder and greater portion having the threads sub-cylindrical, with the tecth arranged in a spiral, the remainder of the thread with undulating ridges, in a varying number of spirals, here and there becoming indistinct, or anastomosing to form an irregular network on the sirface of the thread; spores verruculose, $10.5-11.6 \mu$ diameter.

Arcyria Raciborsckii, Berlese, Sacc., Syll., vii., 1, n. 1467. 
Arcyria decipiens, Racib., Myx. Crac., p. 16, f. 9 (not of Berkeley).

Poland.

\section{Arcyria inermis, Racib.}

Sporangia stipitate, brick-red;' stem filled with cells of various sizes, the interspaces filled with capillitium threads; capillitium forming a network, threads cylindrical or a little flattened, $4.2-10.8 \mu$ broad, protuberances combined into a network, meshes 1.6-2 $u$ long and almost equally broad; spores 9.9-10.8 $\mu$ diameter, membrane firm, reddish, distinctly verruculose.

Arcyria inermis, Racib., Myx. Crac., p. 14, f. 7 ; Sacc., Syll., vii., 1, n. 1465.

Poland.

Position uncertain, owing to absence of information respecting the spores.

\section{Arcyria bonariensis, Speg.}

Sporangia minute, $\frac{1}{2}-\frac{3}{4} \mathrm{~mm}$. long, $\frac{1}{3}-\frac{1}{4} \mathrm{~mm}$. broad, in densely crowded clusters of 5-20 individuals, bright citrin-yellow; stem half as long as peridium and same colour; tubes of the capillitium springing from the hollow of the stem, equal, $3 \mu$ thick, densely muricate, very pale yellowish-green; spores globose, protoplasm granular or guttulate, wall rather thick, $10 \mu$ diameter.

Arcyria bonariensis, Speg., Fung. Arg., Pug. III., n. 90 ; Sacc., Syll., vii., 1, n. 1471.

On old worked wood. Argentine Republic.

Allied to $A$. nutans, but distinct. (Speg.)

\section{Arcyria affinis, Rost.}

Sporangia cylindric-ovate, $1 \mathrm{~mm}$. high, stem of about equal length to sporangium, gregarious; mass of capillitium and spores purple-ferruginous, dull orange-red; threads of capillitium forming a network, lower meshes $3 \cdot 6$, upper $5 \cdot 4 \mu$ broad, markings as in C. incarnata. 
Arcyria affinis, Rost., Mon., p. 276 ; Sacc., Syll., vii., 1, n. 1463. On trunks. Sweden; Germany.

(Rostafinski's Synonyms.)

Arcyria vermicularis, Schum., Fl. Saell., n. 1475, teste Fr. (1803).

Arcyria punicea, $\beta$ vermicularis, Fr., l. c., iii., p. 178 (1829).

Arcyria cinnamomea, Hazsl.

Cinnamon-colour inside and out; sporangia gregarious, at length distinct, cylindrical; stem equal to sporangium in length, diaphonous-white; tubes of capillitium combined into a hexagonal network, 3-4 $\mu$ thick, with short, cylindrical, diaphonous warts; spores cinnamon.

Arcyria cinnamomea, Hazsl., Just., Bot. Jahr., 1877, p. 156 ; Sacc., Syll., vii., 1, 1477.

\section{Arcyria decipiens, Berk.}

Gregarious, sporangia stipitate, obovate, ochraceous, capillitium free above, obovate, erect, with the mass of spores ochraceous; spores globose.

Arcyria decipiens, Berk., Fung. of Darwin's Voy., Ann. Nat. Hist., v., 4, p. 447, t. 10, f. 3.

On palm stem. Rio Janeiro.

Habit of Trichia clavata, but capillitium reticulated, and thread without spirals (Berk.). No specimen exists in Berkeley's herbarium.

B. Hemiarcyria. Threads of capillitium with continuous ridges spirally arranged.

\section{$\S$ Spores minutely warted.}

Arcyria rubiformis, Mass. (figs. 262-264).

Sporangia obovate-oblong, usually fasciculate on a common ridged or contorted stem of variable length, sometimes sub-globose 
and sessile on a hypothallus, rarely an irregular plasmodiocarp, brown or almost black, polished and with a metallic lustre or opaque; mass of capillitium and spores orange-bron'n; threads of capillitium orange-brown, 8-9 $\mu$ thick, combined into a dense elastic net, which at maturity elongates considerably, carrying the apical portion of the sporangium at its apex, where it remains in the form of a cap, free tips numerous, usually terminated by from one to three short, smooth spines, rarely obtuse, spirals rather distant, furnished with numerous slender spines; spores globose, very minutely verrueulose, $10-12 \mu$ diameter.

a. genuina; sporangia cylindrico-turbinate, dark-brown, opaque, or with a steel lustre, seated on a common fasciculate stem.

$\beta$. sessilis; sporangia sessile, cylindrical or sub-angular from mutual pressure.

$\gamma$. plasmodiocarpa; irregular, attached by a broad base to a hypothallus.

Hemiarcyria rubiformis, Rost., Mon., p. 262; figs. 201, 230, 231 ; Cooke, Myx. Brit., figs. 201, 230, 231 ; Schroeter, p. 114; Sacc., Syll., vii., n. 1512; Raunk., Myx. Dan., p. 63, t. 3, f. 15, t. 4, f. 6 ; Mass., Rev. Trich., p. 353, fig. 31 (in part).

Exsice.-Roum., Fung. Gall., 1686 ; Fckl., Fung. Rhen., 1438 (as Trichia rubiformis); Cooke, Fung. Brit., 612 (as Trichia Neesiana); Jack, Leiner u. Sitz. Krypt. Bad., 421 (as Trichia rubiformis); Sacc., Myc. Ven., 962 (as Trichia pyriformis); Hemiarcyria Ellisii, Mass., Rev. Trich., p. 354, f. 30; Karst., Fung. Fenn., 700.

A widespread and very beautiful species, characterized by the cylindrical or obovate-oblong, brown, fasciculate sporangia, frequently exhibiting metallic tints, and the dense orange-brown capillitium of spinulose threads. The spores vary in marking when magnified 1200 diameters from being almost perfectly smooth, to minutely but distinctly warted.

On rotten wood, moss, \&c. Britain (Apethorpe, Weybridge, Twycross, Birmingham, Bulmer, N. Yorks; Orton Wood, Leicester; Wothorpe, Scarboro', Carlisle); France; Germany; 
Switzerland; Italy; Belgium; Denmark; Hungary; Finland; Bohemia; Venezuela; United States; Cuba; Ceylon; Australia; New Zealand.

\section{(Rostafinski's Synonyms.)}

Clathroides pyriforme, Hall, t. 1, f. 5 (1742).

Trichia, Hall, t. 48, f. 5, No. 2167. (1798).

Inycoperdon vesparium, Batsch, t. 30, f. 172 (1786).

Stcmonitis cinnabarina, Roth. Fl. Germ., 347 (1788).

Lycoperdon favaceum, Schr. Fl. Bav., ii., 667 (1789).

I'richia pyriformis, Hoffm. V. Cr., t. 1, f. 1, (1790).

Stcmonitis fasciculata, Pers. in Gmel. Sys., 1468 (1791).

Stcmonitis vesparia, Gmel. Sys., 1070 (1791).

Trichia mubiformis, Pers. Disp., t. 1, f. 3, t. 4, f. 3 (1797);

Berk. Ann. N. H., No. 218; Cooke, Hdbk., No. 1177.

Trichia rubiformis, $\beta$ minor, Pers. Disp., 54 (1797).

Lycoperdon ferrugineum, Hedw., t. 10, f. 1-4 (1802).

Trichia chalybea, Chev. Fl. Par., t. 9, f. 24 (1827).

Trichia Ncesiana, Corda Ic., i., f. 288 c (1837).

Trichia Ayresii, B. and Br., Ann. N. H., No. 390; Cooke,

Hdbk., No. 1179.

\section{Arcyria paradoxa, Mass. (fig. 272).}

Sporangia scattered or aggregated, sessile on a broad base, hemispherical or irregularly elongated, smooth, rather shining, dirty ochraceous, inner surface of the wall with a layer of organic particles; mass of capillitium and spores pale lemon-yellow; capillitium scanty, threads $4-5 \mu$ thick, much contorted and forming a very loose net with but few abmupt free tips, spirals very much crovded, not prominent; spores globose, very minutely warted, 8-10 $\mu$ diameter.

Hemiarcyria paradoxa, Mass., Rev. Trich., p. 356, 357, fig. 35.

On wood. Weybridge; Surrey.

Sporangia when hemispherical about $5 \mathrm{~mm}$. diameter, $1-2$ $\mathrm{mm}$. when elongated. Distinguished amongst species with 
warted spores by the densely crowded spirals of the elaters, and the presence of organic particles on the inner surface of the sporangial wall.

A note by Currey, who collected the specimen, now in the Currey collection in the Kew herbarium, says, "The spores of this specimen sown in water produced de Bary's zoospores in 24 hours."

Arcyria Bucknalli, Mass. (figs. 270, 271).

Sporangia sessile on a broad or narrow base, seated on a very thin hypothallus, circular, reniform, or subangular from mutual pressure, wall very thin, gilvo-ochraceous, soon disappearing; mass of spores dull orange; capillitium well-developed, threads sparingly branched and combined to form an irregular open network with numerous, long, free tips, $4-5 \mu$ thick, walls with annular ridges mostly crowded, but here and there scattered, and sometimes passing into a spiral, the ridges with numerous thin, straight spines $3-4 \mu$ long the free tips irregularly swollen, without spirals or rings, but bristling with spines, as are also certain interstitial swollen portions; spores globose, pale yellow, minutely warted, $7-9 \mu$ diameter.

Hemiarcyria Bucknallii, Mass., Grev., v., 18, p. 27 (1889); Bucknall, Fungi of the Bristol district, in Bristol Nat. Soc. Proc., vol. vi., pt. II., 1889, 1890, p. 4, pl. 2, f. 5.

On wood. Bristol.

Generally crowded, about $5 \mathrm{~mm}$. diameter, but extending to $1.5 \mathrm{~mm}$. when isolated and elongated. Most closely allied to Hemiarcyria Wigandi, Rost., but.at once distinguished by the larger sporangia, the markings on the elaters being mostly rings and not spirals, and in being furnished with numerous spines. The present species combines the characters of Rostafinski's genera Hemiarcyria and Cornuvia, the spirals on the threads of the capillitium pointing to the former, and the numerous free arms to the latter. The spirals technically separate this species from Ophiotheca as understood in the present work. 


\section{Arcyria melanopeziza, Mass.}

Sporangia sessile, creeping, subtercte, generally forming rings, 1-2 mm. long, very black, scarcely or not at all shining, very smooth; wall black, opáque, subcellular, rather coriaceous, splitting longitudinally and dehiscing in a valvate manner; capillitium yellow, protruded elastically, threads round, $4-5 \mu$ thick, combined into a loose net, everywhere covered with erect spines, 5-6 $\times 1 \mu$, spirals almost obsolete; spores elliptico-globose, papilloso-scabrid, $10-12 \times 10 \mu$, yellow.

Henitrichia melanopeziza, Spegazzini, Fung. Arg., Png. IV., n. 268 .

Hemiarcyria melanopeziza, Berlese, Sacc., Syll., vii., 1, n. 1520; Mass., Rev. Trich., p. 356.

On bark. Brazil.

Looking exactly like some black Peziza.

\section{Arcyria calyculata, Mass.}

Sporangia simple, gregarious, stipitate, globose or elliptical, dirty foxy-brown, $1-2 \mathrm{~mm}$. diameter; stem $3-5 \mathrm{~mm}$. long, $200-250 \mu$ thick, round, glabrous, rather tough, apex dilated into a little dimidiate cup equal to the peridium, base dilated, fibrillose, colour of the sporangium; spores and capillitium dingy yellowish-fulvous; elaters $7-8 \mu$ thick, cylindrical, yellowish, sparsely branched, free tips acute; spirals 3-5, fut, not very conspicuous, separated by interspaces their own width, spinulose ; spores discoideo-lenticular, concavo-convex, margin muriculate, $10 \times 3 \mu$ diameter.

Hemiarcyria calyculata, Speg., Fung. Arg., Pug. III., n. 92 ; Sacc., Syll., n. 1518; Mass., Revis. Trich., p. 356.

On rotten willow trunk. Argentine Republic.

It is very doubtful as to whether the spores in the normal condition present the shape described by Spegazzini; the spores of many species become concavo-convex when dry, but if soaked for a sufficient length of time, assume the usual spherical form. 


\section{Arcyria stipitata, Mass.}

Sporangia pyriform, from $2-5$ on a common stem, or solitary, pale lemon-yellow; opaque; stem elongated, equal, dark brown black, longitudinally rugulose; mass of capillitium and spores dingy ochre; capillitium dense, much branched and forming a net without free tips, threads $4-5 \mu$ thick, spirals very open, rather distant, thin, not prominent; spores globose, minutely warted, 7-8 $\mu$ diameter.

a. genuina. Sporangia single on an elongated stem.

$\beta$. fasciculata. Sporangia fasciculate on a common stem.

Hemiarcyria stipitata, Mass., Rev. Trich., p. 354, fig. 32.

On palm stems. Java.

(Type in Herb. Berk., Kew.)

Scattered or aggregated, $3-4 \mathrm{~mm}$. high, stem about $2 \mathrm{~mm}$. long, thin, hollow. Capillitium elastic, protruding after dehiscence. Allied to Arcyria clavata, but distinct in the dense capillitium without free tips, the loose spirals, and the long, thin, black stem.

\section{Arcyria Wigandii, Mass.}

Sporangia clavate, discoid, or irregularly subrotund, very small, almost sessile, mass of spores and capillitium bay or flesh-colcur, verging on yellow; elaters rarely branching, spirals one or two, flexuous, either separated by interspaces from three to four times their own widtl, or crovded and almost forming rings, tips scarcely narrowed, truncate and inflated; spores minutely verruculose, $10-11 \mu$ diameter.

Hemiarcyria Wigandii, Rost., Mon., p. 267, fig. 232 ; Sacc., Syll., vii., 1, no. 1๖17; Cooke, Myx. Brit., fig. 232; Mass., Rev. Trich., p. $3 \check{6} 6$.

Germany.

(Rostafinski's Synonym.)

Trichia abietina, Wigd., 1. c., p. 33, t. 2, f. 11 (1863). 
$\S \S$ Spores with raised bands combined to form a network.

Arcyria chrysospora, Mass. (figs. 268, 269).

Sporangia sessile on a broad base, generally closely aggregated, bright ochraceous yellow; mass of capillitium and spores yellow; threads $5 \mu$ thick, forming a loose net with many free ends, which generally terminate in slightly expanded, smooth, bent or straight conical apices, spirals four, rather close, not prominent, connected by less prominent ridges munning parallel to the long axis of the thread; spores globose, with raised flat bands forming a polygonal network, $16 \mu$ dianeter.

Hemiarcyria chrysospora, Lister, Grev., vol. v., p. 126 ; Mass., Rev. Trich., p. 35̄7, fig. 37.

On larch twigs lying on the ground and on the surrounding herbage. Lyme Regis.

A fine species with the sporangia reaching to $1 \mathrm{~mm}$. diameter, approaching in habit and general structure the form sessilis of Arcyric serpula, but quite distinct in the larger spores, the thinner capillitium threads without spines, and having tho spirals connected by ridges parallel to the axis of the elaters. From three to five polygons on a hemisphere of the spore.

\section{Arcyria serpula, Mass. (figs. 273, 274a).}

Either a vein-like, creeping plasmodiocarp, usually anastomosing to form a net, or subglobose, scattered, and sessile on a broad base, wall thin, fragile, yellow, sometimes tinged brown; mass of spores and capillitium yellow or orange; threads of the dense capillitium $5-6 \mu$ thick, forming a net with numerous free ends which usually terminate in a smooth, thin, tapering spine 8-10 $\mu$ long, spirals thin, not prominent, rathcr distant, furnished with mumerous long, slender spinules; spores globose, with narrow, raised flat bands forming an irregular network, 10-12 $\mu$ diameter.

a. plasmodiocarpa. Plasmodiocarp vein-like, usually forming a network. 
$\beta$. sessilis. Sporangia sessile on a broad base, scattered or gregarious, capillitium orange, elastic.

Hemiarcyria serpula, Rost., Mon., p. 267, figs. 200, 227, 228 ; Cooke, Myx. Brit., p. 68, figs. 200, 227, 228; Schroeter, p. 115; Sacc., Syll., vii., pt. I., n. 1514; Raunk., Myx. Dan., p. 64, t. 3, f. 16 ; Mass., Rev. Trich., p. 357, f. 34.

Exsicc.-Fuckel, Fung. Rhen., 2692 (as Hemitrichia contorta (Ditm.) Rost.).

On rotten wood, branches, leaves, \&c. Britain (Carlisle; specimen in Herb. Berk., from Sowerby's herbarium, no locality, called Trichia reticulata, undoubtedly British); Germany; Sweden; Belgium; Italy; United States; Cuba; St. Vincent; Bombay; N. W. Australia; New Zealand; Ceylon.

Distinguished amongst the clear yellow species by the very spiny elaters and the reticulate spores. The subglobose sessile form has not, so far as I am aware, been met with in Britain, but, although differing in habit and in the bright orange elastic capillitium, agrees in the structure of the elaters and the spores. The type of the form sessilis is in the herbarium of the Paris Museum, and was collected in Cuba.

\section{(Rostafinski's Synonyms.)}

Mucor serpula, Scop. Fl. Carn., t. 65 (1772).

Lycoperdon lumbricale, Batsch., f. 174 (1786).

Trichia spongioides, Vill. Fl. Dauph., 1061 (1789).

Stemonitis lumbricalis, Gmel. Sys., 1470 (1791).

Trichia reticulata, Pers. Disp., 10 (1797); Ic. and Desc., t. 12, f. 1

Trichia serpula, Pers. Disp., 10 (1797); Eng. Fl., v., 320;

Cooke, Hdbk., 1189.

Trichia serpula, $\beta$ spongioides, Pers. Syn., 181 (1801).

Trichia venosa, Schum. Saell., 1456 (1803).

Hyporhamma reticulatum, Corda Ic., v., 34 (1842).

Trichia retiformis, Payer. Crypt., f. 574 (1850).

Arcyria clavata, Mass. (fig. 124).

Sporangia varying from clavate to globose, ycllowish, polished, 
stem thin, length variable, yellow, often reddish at the base, filled with large, globose, or subangular cclls, which pass upwards into normal spores; mass of spores clear yellow, ochraceousorange, or tinged with olive; threads of capillitium $4-5 \mu$ thick, forked repeatedly and combined into an irregular open net, frec ends not numerous, obtuse, sometimes slightly swollen, spirals thin, not prominent, rather distant; spores globose, very minutely and irregularly reticulated, 8-10 $\mu$ diameter.

Hemiarcyria elavatc, Rost., Mon., p. 264, figs. 205, 207, 210, 238; Cke., Мyx. Brit., p. 68, figs. 205, 207, 210, 238; Sacc., Syll., vii., 1, n. 1513; Mass., Mon. Trich., p. 31 ; Raunk., Myx. Dan., p. 64; Schroeter, p. 114.

Exsicc.-Fckl., F. Rhen., 1434; Jack, Leiner u. Sitzenb. Krypt. Badens., 621 ; Ellis, N. Amer. Fung., 523.

On decayed wood, \&c. Britain (King's Cliffe, Apethorpe, Scarboro', Carlisle); France; Germany; Denmark; United States; Cuba; Brazil; Ceylon; Bonin Islands.

Scattered or gregarious, $1.5-2 \mathrm{~mm}$. high, stem slender, often attenuated downwards and longitudinally wrinkled, sometimes very short, especially when the sporangium is almost globose.

The spores are usually covered with very thin, slightly raised ridges combined into a very fine, irregular network, but the ridges are sometimes short and distinct or even wart-like.

\section{(Rostafinski’s Synonyms.)}

Clathrus pedatus, Schm. Ic., t. 33, f. 1, 17 (1776).

Sphacrocarpnes pyriformis, Bull., t. 417, f. 2 (1791).

Stemonitis pyriformis, Gmel. Sys., 1469 (1791).

Trichia pyriformis, Sibth. Fl. Ox., 406 (1794); Sow., 400, f. 6. Trichia clavata, Pers. Disp., p. 11 (1797); Eng. Fl., v., 320;

Cooke, Hdbk., 1183.

Trichia citrina, Schum. Saell., 1460 (1S03).

Arcyria trichioides, Rudolph, Linnaea, p. 120 (1829).

Trichia erythropus, Borszczow (1856).

Trichia obtusa, Wigand, p 30, t. 11, f. 4 (1863).

Trichia Thwaitesii, B. and Br., Ceylon Fung., No. 776 (1873). 


\section{$\S \S \S$ Spores smooth.}

\section{Arcyrio leiocarpa, Mass.}

Sporangia scattered or aggregated, obovate or pyriform, rarely almost globose, pallid, stem same colour, as long as diameter of sporangium; mass of capillitium and spores concolorous, or with a slight ochraceous tint; capillitium sparse, forming a loose net, threads $5 \mu$ thick, spirals thin, rather close, slightly prominent on the convex side of the bent threads, usually furnished with scattered, rudimentary spinules, free tips very rare or absent; spores globose, smooth, 12-14 $\mu$ diameter.

Hemiarcyric leiocarpa, Cooke, Myx., U. States, in Ann. Syc. Nat. Hist., New York, xi., n. 12, p. 405 ; Cooke, Myx. Brit., figs. 252, 2555 ; Sacc., Syll., vii., 1, n. 1519 ; Mass., Rev. Trich., p. 353 , fig. 33 .

In Saccardo's Sylloge VII., pt. I., p. 440, n. 1519, Rostafinski is given as the author of the present species, and the reader is referred to "Rost., Mon., p. 267" for the description, but in reality the present species is not included in Rostafinski's work.

\section{Arcyria leocarpoides, Mass.}

Sporangia globose or pyriform, $0.6-0.8 \mathrm{~mm}$. diameter, fleshred or fulvous, often depressed and deeper coloured at the apex, not at all or only a little shining, very smooth, cortex rather thick, subcartilaginous, soon breaking away in pieces above, usually persistent, cup-like at the base; stem rather rigid, erect, brownish or blackish, slender, even or subrugulose, about as long as diameter of sporangium; capillitium after dehiscence protruding elastically, attached at the base, very persistent, brownish-fúlvous, or olive-fulvous, threads slender, cylindrical, 5-6 $\mu$ thick, forming a dense net with numerous terete, abruptly rounded free arms, threads with 3-4 spirals, very smooth, not papillate; spores globose, $8-10 \mu$ diameter, very smooth, protoplasm granular, fulvous-olive.

Cornuvia leocarpoides, Speg., Fung. Arg. Pug. I., n. 264; Sacc., Syll., vii., 1, n. 1546.

On rotten wood. Brazil. 
The stipitate sporangia and elastically protruded capillitium attached at the base, as also the spiral markings on the threads prove the present species to be an Arcyria, in which genus free arms to the capillitium are frequent in several species.

\section{Arcyría Karsteni, Rost.}

Sporangir effused, vermiform, sinuous, sometimes forming irregular reticulations, or hemispherical, scattered, and sessile on a broad base, varying from dirty ochraceous brown to dark chestnut; mass of capillitium and spores dingy ochre; threads often irregularly branched, and forming a very loose net, $3-4 \mu$ thick, with scattered, iniflated portions $12-15 \mu$ thick, and $30-50 \mu$ long, spirals very indistinct, a few scattered rudimentary spines now and then present, free tips not distinctly attenuated, usually abrupt or clavate; spores globose, smooth, 12-12 $\mu$ diameter.

Hemiareyriu Karsteni, Rost., Mon. Suppl., p. 41 ; Karst., Myx. Fenn., iv., p. 142 ; Schroeter, p. 115; Sacc., Syll., vii., 1, n. 1516; Mass., Rev. Trich., p. 342, fig. 36.

(Specimen from Ceylon in Herb. Berk., named by Rostafinski.)

On wood. Finland; Silesia; Ceylon.

Characterized by the threads of the scanty capillitium being considerably swollen at intervals, and by the indistinct spirals.

\section{Arcyria pusilla, Mass.}

Sporangia rather' closely gregarious, subcylindrico-elliptical, $0.4-0.5 \mathrm{~mm}$. high, $0.15-0.25 \mathrm{~mm}$. diameter, rather obtuse above, abruptly subtruncate below, with only a trace of a stem or altogrether without; at first blood-red with an amber tinge, cftervards rose-colour ; capillitium rather dense, forming a rosecoloured network, threads round, $3-4 \mu$ thick, spirals three or four, furnished with minute spinules; spores rose or flesh-colour, globose, smooth, 7-9 $\mu$ diameter.

Ionitrichia pusilla, Speg., Fung. Arg. Pug., IV., n. 269.

Hcmicurcyria pusilla, Berlese, Sacc., Syll., IV., 1, n. 1512; Mass., Rev. Trich., p. 352.

Ou bark. Argentine Republic. 
Arcyria fuliginea, Cke. and Mass. (fig. 113).

Sporangia (?), mass of capillitium and spores smoky-olive, threads round, $6-7 \mu$ diameter, thickly and equally covered with slender spines 3-4 $\mu$ long, combined to form a dense, irregular network; spores globose, smooth, $8 \mu$ diameter.

Hemiarcyria fuliginea, Cke. and Mass., Grev., vol. xvi., p. $7 \dot{4}$.

On living leaves. Mount Wilson, N. S. Wales.

Nothing is known of the sporangium, which had been completely crushed and lost; capillitium forming a large mass spreading over the leaves. May possibly prove to be a broadly effused, plasmodiocarp form of an Ophiotheca.

\section{Sub-sect. Tricheae.}

\section{Oligonema, Rost.}

Wall of sporangium single, dehiscing irregularly; capillitium scanty, composed of free; simple or branched elaters, furnished with ring-like thickenings, or a single very diffuse, rudimentary spiral, tips obtuse.

Oligonema, Rost., Mon., p. 291; Cooke, Myx. Brit., p. 77; Sacc., Syll., p. 436; Mass., Rev. Trich., p. 21.

Agreeing with the genus Trichic in having the elaters perfectly free, but readily distinguished by the rudimentary markings on their walls, never having more than a single, indistinct, very open spiral, which may be present on one portion of an elater and absent on another part, or not unfrequently altogether absent from all the elaters of one sporangium, and present on some of those from another sporangium taken from the same group. A second type of ornamentation on the walls of the elaters in the present genus consists of annular or ring-like thickenings, which present the appearance of thin, flat discs, rather larger than the diameter of the elater, and placed at right angles to its long axis. These ring-like thickenings are very unequally distributed, five or six being sometimes met with at unequal distances on an elater, whereas they may 
be entirely absent from all the elaters next examined. These annular thickenings are also met with on the threads of the capillitium of some species of Cornuvia, Didymium, Tilmadoche, \&c. In rare instances the two ends of an elater coalesce and form a closed ring, as figured by Rostafinski in Oligonema nitens, Rost., Mon., fig. 198.

Distrib. Europe; North Africa; North America. Species 7.

* Epispore reticulated.

Oligonema nitens, Rost. (figs. 193-195).

Sporangia densely crowded, in one or several superposed layers, when scattered, sessile on a broad or slightly contracted base, clear primrose-yellow, very smooth and shining; mass of capillitium and spores yellow; elaters scanty, $4-5 \mu$ thick, simple or sparingly branched, very variable in marking, with scattered, thick, projecting rings, or a very indistinct, open spiral on the whole or part of an elater, or a combination of both, not unfrequently perfectly smooth, tips obtuse or more or less pointed; spores globose, with narrow raiscd ridges of varying thicliness, forming an irregular nctwork, 11-13 $\mu$ diameter.

Oligonema nitcns, Rost., Mon., p. 291, f. 198; Cke., Myx. Brit., f. 198; Schroeter, p. 108 ; Sacc., Syll., n. 1488 (the sporangium described as of a gilvous colour by mistake); Mass., Rev. Trich., p. 347, f. 29.

Oligonema bavarica, Balf. and Berl., Sacc., Syll., n. 1490.

Oligonema nitens, a bavarica, Mass., Rev. Trich., p. 347, f. 25.

Trichia nitcns, Libert, Pl. Cr. Ard., fasc. iii., n. 227.

Exsicc.-Lib., Pl. Crypt. Ard., fasc. iii., n. 227 (as Trichia nitens); Klotzsch, Herb. Myc., (Rabeuh.) 137 (as Trichia circumseissa); Fuckel, F. Rhen., 2198 (as Trichiu nitens); de Thum., Myc. Univ., nos. 399 and 1497 (as Trichia Bavarica).

On wood, bark, \&c. Britain (Carlisle, Bristol, Birmingham); France; Bavaria; Germany.

Sporangia :5-1 mm. diameter, clear yellow, polished; the elaters are extremely variable in marking, as is also the 
epispore, but the latter always in the markings forming a reticulation.

\section{Oligonema flavidum, Mass.}

Sporangia crowded, sessile, bright yellow, shining, mass of capillitium and spores bright yellow; elaters scanty, short, $4-5 \mu$ thick, sometimes with an elliptical interstitial swelling, tips variable, subacute or inflated, densely covered with minute raised points; spores globose, with thin raised bands combined to form a very irregular network, bands not punctate, $7-9 \mu$ diameter.

Perichaena flavida, Peck; 26th Annual Report of New York State Mus., p. 76 (1874).

On moss, wood, \&c. United States.

The sporangia are irregular in form, circular, angular, or elongated. Forming patches of considerable extent.

Superficially resembling 0 . nitens, but distinct in the elaters and spores. The elaters agree with those of 0 . minutula in being rugulose or covered with small points or band-like wrinkles, but in the present species the spores are smaller and the reticulations more irregular in form and size.

\section{Oligonema minutulum, Mass.}

- Sporangia scattered, rarely aggregated, sessile on a narrow base, lemon-yellow, dull, capillitium very scanty, elaters simple, short, cylindrical, 5-6 $\mu$ thick, rugulose, and with a very open, indistinet spiral, tips obtuse, rounded; spores globose, and with slightly raised, flattened bands forming a networth of numerous, almost regular and equal-sized polygons, 12-14 $\mu$ diameter.

Oligonema minutula, Mass., Rev. Trich., p. 348, fig. 20.

Type in Herb. Berk., Kew, no. 10902, marked "Trichia minutula, D. R., et Montag., Algiers," Algeria.

So far as I am aware, the present species has not been described by Montague. Related to 0 . nitens, but known by the scattered, dull sporangia, and the very few, short elaters having thick, rugulose walls, with an indistinct open spiral; 
in rare instances a swollen portion $15-20 \mu$ long, and 8-12 $\mu$ thick is present near the middle of an elater, but there is no indication of the narrow, ring-like thickenings as in 0 . nitens. From 7-9 complete polygons present on a hemisphere of a spore.

\section{* Epispore warted.}

Oligonema Broomei, Mass. (figs. 185, 186).

Sporangia scattered or in small groups, adnate by a broad base, hemispherico-depressed, circular or irregularly elongated, wall smooth, dark brown, dull; mass of capillitium and spores reddish-ochre; elaters cylindrical, 3-4 $\mu$ thick, irregularly branehed, dull-orange, furnished with narrow, ring-like thickenings, at regular distances, tips obtuse; spores rather coarsely warted, dull orange or yellowish, globose, $13-14 \mu$ diameter.

Oligonema Broomei, Mass., Rev. Trich., Journ. Roy. Micr. Soc., 1889, p. 345, pl. vii., f. 22.

(Type in Herb., Broome in Brit. Mus., marked "Trichia serpula" (?).)

On bark. Britain (Warleigh, Somerset).

The present species is most neary allied to $O$. acneum, Karst., which has up to the present been only met with in Finland, and is distinguished by the crowded habit, polished sporangia with metallic tints, and smaller spores.

When circular the sporangia vary from $5-1 \mathrm{~mm}$., and when elongated 2-3 $\mathrm{mm}$. long.

\section{Oligonema aeneum, Karst.}

Sporangia densely crowded, often confluent and venulose, rarely scattered, orbicular or angular from mutual pressure, depressed, shining, with copper, green, or olive metallic tints; threads of the capillitium free, $2-3 \mu$ thick, with scattered thickenings in the form of circles; spores globose, warted, rather ferruginous or pale reddish-ochre, $12 \mu$ diameter.

Oligonema aeneum, Karsten, Myc. Fenn., iv., p. 125 ; Sacc., Syll., n. 1487; Mass., Rev. Trich., p. 346.

Finland. 


\section{Oligonema furcatum, Bucknall.}

Sporangia scattered, globose, shining, bright chrome-ycllow, as well as the capillitium and spores; elaters cylindrical, simple or branched, slightly thickened at the obtuse ends, with a faint open spiral, 3-4 $\mu$ diameter; spores globose, minutely wartcd, $11-12 \mu$ diameter.

Oligonema furcatum, Bucknall in litt.

On a rotting trunk. Britain (Abbotts Leigh).

Superficially closely resembling Oligonema nitens, from which however it is quite distinct in the minutely warted spores, and the absence of thickened rings on the usually furcate elaters.

\section{Oligonema brevifilum, Peck.}

Sporangia crowded in effused heaps, bright ochraceous yellow ; elaters few, short, cylindrical or subfusiform; spores globose, rugose, $11 \mu$ diameter.

Oligonema nitens, Peck, in 31st Report of State Agric. Mus., p. 42 ; Sacc., Syll., n. 1489; Mass., Rev. Trich., p. 346.

On mosses. United States.

Mr. Wingate of Philadelphia thinks that the present species waill prove to be an abnormal condition of 0 . flavida.

\section{Trichia, Haller (emended).}

Wall of sporangium single, dehiscing irregularly; capillitium consisting of free, simple or branched threads, having the wall furnished with raised bands arranged in a spiral manner; spores globose, epispore smooth, or variously ornamented.

Trichia, Haller, Helv., iii., p. 114 ; Rost., Mon., p. 243 ; Cooke, Myx. Brit., p. 61 (in part); Sacc., Syll., vol. vii., pt. I., p. 438 (in part); Mass., Mon. Trich., p. 328.

The genus is readily distinguished by the presence of welldeveloped external ridges arranged in a spiral manner on the perfectly free elaters or threads of the capillitium. The elaters are in most species unbranched, cylindrical or fusiform, and more or less attenuated at the tips. In a few species the 
elaters are branched, the free ends varying from three to ten in number. The only other genus with free elaters is Oligonema, but here the spirals are at most rudimentary and the tips obtuse.

Distrib. All temperate and tropical countries. Species 30.

\section{A. Spores smooth.}

\section{Trichia Carlyleana, Mass. (173-175).}

Sporangia clavate or cylindric-oblong, stipitate, dark brown, often with a purple tinge, smooth; stem usually about half as long as sporangium, equal, or slightly thickened downwards and expanded at the base into a small circular hypothallus; inner surface of sporangial wall and hollow of stem with numerons rather large organic lumps, of a bright reddish-purple colour; mass of spores bright yellow ; elaters fusiform, $5-0 \mu$ at thickest part, simple or frequently branched, tips running into a long, smooth, very thin, straight or flexuous spine, spirals crovded, thin, not prominent; spores globose, smooth, 10-12 $\mu$ diameter.

Trichia Carlylcana, Mass., Mon. Trich., p. 5, f. 15.

On wood. Britain (Carlisle).

Sporangia in fascicles of $3-5 ; 2-3 \mathrm{~mm}$. high. Superficially resembling some forms of Trichic fragilis, but quite distinct in the smooth spores, and the narrow, crowded, and not at all prominent spirals of the elaters. The colouring matter in the organic lumps on the wall of the sporangium and in the stem is soluble in dilute potassic or ammonia hydrate.

\section{Trichia heterotrichia, Balf.}

Sporangia sessile in clusters, dark yellow, wall thick, tough and leathery, inner layer areolate; elaters few, eylinulvical, $7 \mu$ diameter (thickenings excluded), with walls of medium thickness, irregularly and variously thickened, either with spines often twice diameter of elaters, or with short prickles or warts, or with complete or half-rings, or sometimes with interrupted and irregular spirals leaving large intervening unthickened portions, swollen towards the extremities, and ending in a 
tapered, rarely smooth, arcuate or twisted point, in length twice the diameter of elater; spores globose, pale yellow, smooth, 16-17 $\mu$ diameter.

Trichia heterotrichia, I. B. Balfour, Grev., vol. x., p. 117; Sacc., Syll., n. 1505 ; Mass., Mon. Trich., p. 5, f. 16.

On bark. Britain (in Herb. Currey, Kew; no locality).

A species resembling most nearly forms of Trichia varia, Pers., but the few elaters with the very varying sculpturing and the larger smooth spores sufficiently separate them. (I. B. B.)

\section{B. Spores warted.}

\section{$\S$ : Elaters fusiform.}

Trichia fragilis, Rost. (figs. 7-10).

Sporangia varying from globose to pyriform, stipitate, solitary, or fasciculate on a common stem, wall smooth, blackish or purple-brown, pale brown or yellowish; stem dark, longitudinally wrinkled, equal or tapering upwards, erect or curved, often twisted in the compound forms, inside of the wall often with coloured organic lumps; mass of capillitium and spores varying from dull orange-brown to primrose-yellow, scparated from the hollow of the stem by a membrane; elaters fusiform, $4-5 \mu$ at thlckest part, sometimes branched, spirals flat, rather broad, not very prominent, tips smooth, tapering to a thin point, spores globose, minutely warted, $11-14 \mu$ diameter.

a. genuina. Sporangia pyriform, solitary or fasciculate, clear or black-brown, opaque; mass of capillitium and spores varying from reddish-brown to dirty ochre; stem erect.

ß. Lorinseriana. Sporangia pyriform, solitary or fasciculate, reddish.brown, polished; mass of capillitium and spores dirty ochraceous; stem generally curved.

$\gamma$. serotina. Sporangia clavate or pyriform, solitary or fasciculate; mass of spores and capillitium clear yellow to ochraceous; stem erect or curved.

ס. lateritia. Sporangia subglobose, solitary or fasciculate, almost black ; mass of capillitium and spores dark orange-brown; stem attenuated upwards. 
Trichia fragilis, Rost., Mon., p. 246, figs. 203, 204, 225, 226 (in part); Cooke, Myx. Brit., p. 63, figs. 203, 204, 205, 226 (in part); Sacc., Syll., vii., 1, n. 1494 (in part); Balf., Grev. v., 10, p. 116 (in part); Mass., Mon. Trich., p. 6, figs. 14 and 28.

Trichia latcritia, Lev., Ann. Sci. Nat., Ser. III., vol. v., p. 167 ; Sacc., Syll., vii., n. 1494; Balf., Grev., vol. x., p. 116.

Trichia botrytis, Schroeter, p. 112; Raunk., Myx. Dan., p. 67. Sphacrocarpus fragilis, Sow., t. 279.

Exsicc.-Cke., Fung. Brit., 612 ; Rab., Fung. Eur., 244; Jack, Leiner. u. Sitzenb. Krypt. Badens., 329; Erbar. Critt. Ital., 640 ; Ellis and Everh., N. Amer. Fung., Ser. II., 2097 aud 2098; Fuckel, Fung. Rhen., 1437.

On wood, twigs, \&c. Britain (Brighton, Kew, Gloucester, Castle Howard, Yorks ; Carlisle, Appin, N. B.); Europe; United States; Canada; Chili ; S. Africa ; Ceylon; S. W. Australia ; Tasmania; N. Zealand.

A variable species in colour of sporangium and mass of spores and capillitium. The distinguishing characters are the fusiform elaters with long, smooth, tapering tips and flat spirals, and the warted spores. Varying from 2-4 mm. high; solitary, or in more or less confluent clusters of from $2-7$ on a common stem, which is obviously composed of several confluent'stems, and hence forming a stipitate acthalium. The elaters are sometimes branched near the tips. I have examined the type specimen of Trichic lateritia in the Paris Museum, and find that it agrees exactly with Trichia fragilis in the structure of the spores and capillitium.

\section{(Rostafinski's Synonyms.)}

Lycoperdon bombacinum, Batsch, El., p. 153 (1783).

Stcmonitis botrytis, Pers. in Gmel. Syst., 1468 (1791).

Trichia botrytis, Pers. Disp., p. 9 (1797); Ic. Pict., t. 12, f. 1-2.

Trichia botrytis, $\beta$. minor, Pers. Disp., jł (1797).

Trichia scrotina, Schrad., Journ., t. 3, f. 1 (1799); Engl. Fl., v., p. 310; Cooke, Hdbk., No. 1181. 
Sphacrocarpus fragilis, Sow., t. 279 (1803).

Trichica notata, Fl. Dan., 1680 (1823).

Trichia badia, Fr. Stirp. Femsj., 83 (1825).

Trichia pyriformis, Fr., S. M., iii., 184 (1829); Curr., Micr.

Journ., v., p. 129 ; Cke., Hdbk., n. 1178.

Trichia Lorinseriana, Corda, Ic., f. 228 D (1837); Curr.,

Micr. Journ., v., p. 129 ; Cke., Hdbk., n. 1180.

Trichia pyriformis, $\beta$. serotina, Rost., in Fckl. Symb., 2 N., 75 (1873).

Craterium floriforme, Schu., Ann., No. 2307.

Alvisia bombarda, B. and Br., Ceylon Fung., No. 784, t. 2, f. 6 (1873).

Trichia purpurascens, Nyl. (figs. 183, 184).

Sporangia stipitate, ovate or spherico-ovate, solitary or gregarious, purplish-red, opaque; stem longitudinally wrinkled, erect or cernuous, rather firm and thickish, expanding at the base into a small hypothallus, coloured like the sporangium, which it equals or exceeds in length; mass of elaters and spores bright ochraceous; elaters rather short, fusiform, attenuated into long, tapering, smooth, straight or flexuons tips, simple or branched, about $5 \mu$ thick at the centre, spirals sharp-edged, rather prominent and distant; spores globose, vernuculose, yellow, $9-11 \mu$ diameter.

Trichia purpurascens, Nyl., in Sällsk. pro Faun. et Flor. Fenn. notis. Ny., Ser. 11., 2, p. 126 ; Mass., Rev. Trich., p. 332; Sacc., Syll., no. 1508; Grev., v., 18, p. 27 (1889); Karst., Myx. Fenn., iv., p. 137.

On fir-wood, moss, \&c. Britain (Carlisle); Finland.

Requires to be carefully distinguished from some forms of Trichia fragilis, to which species the present is closely allied. In $T$. purpurascens the spirals are sharp-edged, in T. fragilis flattened. The inner surface of the sporangial wall is studded with amorphous, organic purple particles; the colouring matter is soluble in potassic or ammonic hydrate. 


\section{$\S \S$ Elatcr's cylindrical.}

* Spirals not spinulose.

Trichia varia, Rost. (figs. 169-172).

Sporangia scattered or aggregated, stipitate, or sessile on a narrow or broad base, turbinate or subglobuse, smooth, yellow, dirty ochraceous or tinged with olive; stem when present blackish; mass of capillitium and spores yellow; claters cylindrical, $4-5 \mu$ thick, spirals distant, prominent, more especially on the convex side when curved, rarely branched, tips smooth, tapering, straight or bent, $8-10 \mu$ long, sometimes shorter; the elaters are sometimes swollen at the commencement of the tapering tips; spores globose, minutely warted, $10-14 \mu$ diameter.

Trichia varia, Rost., Mon., p. 251, figs. 191, 202, 208, 212, 218, 237; Cooke, Myx. Brit., p. 63, figs. 191, 202, 208, 212, 218, 237; Schroeter, p. 112; Sacc., Syll., vii., 1, no. 1497; Raunk., Myx. Dan., p. 65, t. 3, f. 14, t. 4, f. 3; Mass., Mon. Trich., p. 9, f. 17.

Exsicc._Jack, Leiner u. Sitz., 419 ; Karst., Fung. Fenn., 288 and 699 ; Fuckel, Fung. Rhen., 1431 and 1433; Roum., Fung. Gall., 1101 and cent. xiv. 1315; Rab., Fung. Eur., 799, 2137 and 2138; Thum., Myc. Univ., 1999; Sacc., Myc. Van., 794.

On bark, wood, moss, \&c. Britain (Kew, Bishop's Wood, Highgate; Weybridge, Scarboro', Carlisle, Abergavenny, Appin, N. B.); France; Denmark; Germany ; Finland; Italy; Bohemia; United States; Tasmania; New Zealand; Australia.

A variable species, sometimes with a distinct, dark-coloured stem, at others quite sessile on a narrow or broad base. Characterized by the cylindrical elaters with distant, prominent spirals, and the minutely warted spores. In the specimen in Rabenh., Fung. Eur., n. 2137, the warts show a slight tendency to become elongated and flattened.

(Rostafinski's Synonyms.)

a. Trichia varia, v. nigripes.

Mucilago minima, Mich., t. 96, f. 4 (1729). 
Embolus albissimus, Hall, Herb., p. 8 (1742).

Embolus,' Hall, No. 2138 (1768).

IIucor pyriformis, Scop. Fl. Carn., 492 (1772).

Mucor pomiformis, Leers Fl. Herb., 1136 (1775).

MIucor lacteus, Leers Fl. Herb., 1132 (1775).

Stemonitis pyriformis, Willd. Fl. Ber., 409 (1787).

Embolus lacteus, Hoff. Veg. Cr., t. 2, f. 3 (1790).

Sphaerocarpus chrysospermus, Bull., t. 417, f. 4 (?).

Trichic olivacea, Pers. Obs., i., 62 (1796).

Arcyria olivacea, Ransch (1797).

Trichice cylindrica, Pers. Obs., ii., 33 (1799).

Trichia cordata, Pers. Obš., ii., 33 (1799).

Trichia nigripes, Pers. Syn., 178 (1801).

a pyriformis, $\beta$ cordata, $\gamma$ cylindrical, $\delta$ vulgaris; Fl. Dan., t.

1313, f. 2; Curr., Micr. Journ., v., p. 128 ; Cooke, Hdbk.,

No. 1185 .

Trichia cratcrioides; Corda, Ic., ii., f. 85 (1838).

\section{$\gamma$ Trichia varia, v. genuina.}

Lycogala luteum, Mich., t. 95, f. 4 (1729).

Mucor quintus, Schff., 296 (1770).

Mucor granulatus, Schff., No. 286 (1770).

Lycoperdon vcsiculosum, Batsch., 283 (1786).

Sphaerocarpus chrysospermus, Bull., t. 417, f. 4 (?).

Stemonitis varia, Pers. in Gmel. Sys., 1470 (1791).

Stemonitis vesiculosa, Gmel. Sys., 1470 (1791).

Trichia olivacea, Pers. Obs., l., 62 (1796).

Trichia varia, Pers. Disp., p. 10 (1797); Eng. Fl., v., 320;

Cooke, Hdbk., No. 1188.

Lycopcrdon luridum, Hedw. Obs., t. xi. A (1802).

Trichia favoginea, Schum. Saell., 1455 (1803).

Trichia applanata, Hedw., in DC. Organ, t. 60, f. 1 (1827).

\section{Trichia nitens, Fries.}

-Sporangia sessile on a broad base, crowded, hemispherical, convex above, circular or angular from mutual pressure, prim- 
rose-yellonv, polished, shining; mass of spores and elaters dullorange; elaters cylindrical, 14-16 $\mu$ thick, rather short, ending in a very short, abrupt, smooth apiculus, spirals rather prominent, distant, without spines; spores globose, with rather large, rounded warts, 14-16 $\mu$ diameter.

Trichia nitens, Fries, MS.; Mass., Mon. Trich., p. 333, fig. 11.

(Specimen from Fries in Herb. Berk., Kew, and named by Fries "Trichia nitens, Fr.")

On wood. Upsala.

A very fine large species, forming dense clusters 1 in. and more across. Externally resembling Oligonema nitens, Rost., distinct from T. vavia in the polished, shining sporangia, and the thicker elaters, with very short, abruptly apiculate tips.

\section{Trichia inconspicua, Rost.}

Sporangia very minute, bronen, shining, subspherical, collected in clusters or scattered; hypothallus absent; elaters eylindrical, 3:3 $\mu$ thick, tips pointed, $6-7 \mu$ long, curved, sometimes with elongated swellings near the ends, spiruls 3-4, but slightly mominent, rather close; spores delicatcly verruculose, $10-12 \mu$ diameter.

Triclica inconspicua, Rost., Mon., p. 259 ; Sacc., Syll., n. 1502 ; Mass., Mon. 'Trich., p. 335.

Germany; France.

\section{Trichia proximella, Karst.}

Sporangia substipitate or sessile, circular or irregularly angular from pressure, yellow or dingy ochraceous, polished; mass of elaters and spores ochraceons; claters cylindrical, sometimes branched, ending abruptly in a short, smooth, straight or oblique apiculus, 4-5 $\mu$ thick, spirals promincnt, distant; spores globose, rather coarscly warted, 12-14 $\mu$ diameter.

Trichia proximella, Karst., Myc. Fenn., iv., p. 139; Sacc., Syll., vii., 1, no. 1507 ; Mass., Mon. Trich., p. 335.

On wood. Finland. 
Allied to Trichic nitens, but known by the much thinner elaters. Forming crowded patches of considerable extent.

\section{Trichia advenula, Mass. (figs. 142-144).}

Sessile on a broad base, densely crowded or with a few outside scattered sporangia, circular, or subangular from mutual pressure, rather depressed, primrose-yellonv, shining; mass of capillitium and spores orange; elaters cylindrical, $4-5 \mu$ thick, usually inflated at one or both ends, and also with 1-3 interstitial swollen portions, the swollen ends terminating in a thin, straight, or usually flexuous slender spine, $15-20 \mu$ 'long, spirals very close, but little prominent, almost obsolete on the swollen portions; spores globose, minutely verruculose, 12-14 $\mu$ diameter.

Trichia advenula, Mass., Rev. Trich., p. 336, fig. 38.

On rotten wood. Glamis, N. B.

Sporangia $5 \mathrm{~mm}$. diameter, forming densely crowded patches 1-2 inches across. Most nearly related to Trichia minima, but distinguished by the long, slender tips to the elaters, and the interstitial swollen parts; in T. minima the capillitium and spores are pale primrose in the mass, and not orange as in the present species.

Trichia nana, Mass.

Sporangia scattered or aggregated in small clusters, rarely exceeding $.5 \mathrm{~mm}$. in diameter, sessile on a broad base, smooth, pale bright ochre, opaque, wall very thin; mass of spores and elaters pale primrose yellow; elaters cylindrical, short, 3-4 $\mu$ thick, spirals irregular, very distant, prominent, tips abrupt, not apiculate, the spirals usually running quite to the end; spores globose, minutely verruculose, $6-8 \mu$ diameter.

Trichia nana, Mass., Mon Trich., p. 336.

(Type in Herb., Kew.)

On wood. Westbrook, Maine, U. S.

Sporangia hemispherical or sausage-shaped; by far the smallest of known species, resembling superficially T. minima, from which it differs in the distant and prominent spirals of 
the elaters; in the latter character it agrees with $T$. varia, but differs in the spirals not being markedly more prominent on the convex side of the bent elaters, the abrupt tips, and smaller size of every part. The elaters are rarely more than $200 \mu$ long.

\section{Trichia minima, Mass.}

Sporangia crowded, sessile on a broad base, circular, elliptical, or irregular from nutual pressure, pale primrose-yellow; mass of claters and spores same colour; elaters cylindrical, $5-7 \mu$ thick, ending in smooth, tapering points about $8-10 \mu$ long, spirals thin, rather distant, not prominent, without spines; spores globose, very minutcly wartcd, $10 \mu$ diameter.

Trichia minima, Mass., Rev. Trich., p. 336, fig. 18.

On wood. Britain (Oldham).

Sporangia $5 \mathrm{~mm}$. diameter, forming dense clusters. Allied to $T$. scabru, but distinct in the smaller size of every part, and in the absence of spines on the spirals of the elaters.

\section{Trichia contorta, Rost.}

Plasmodiocary creeping, flexuous, subcmpressed, umber or baybroun; mass of elaters and spores yellow; elaters $2.5-3.5 \mu$, cylindrical, tips usually swollen and terminated by a long, slender spine; there is sometimes an interstitial swelling; spirals indistinect; spores globose, minutely warted, 12-15 $\mu$ diameter.

Trichia contorta, Rost., Mon., p. 259, f. 229 ; Cooke, Myx. Brit., f. 229 ; Schroeter, p. 113; Sacc., Syll., vol. vii., pt. I., no. 1503 ; Raunk., Myx. Dan., p. 68, t. 3, f. 13; Mass., Rev. Trich., p. 337.

On rotten wood. Britain; Germany; France; Denmark; Sweden; Australia.

I have seen no specimen of the present species, which is said to have occurred in Britain. The cylindrico-compressed flexuons plasmodiocarp of a dark brown colour, and the elaters with long, spine-like tips and indistinct spirals mark the species. The elaters appear to agree in structure with those of Trichia 
advenula, but the latter differs in every other character. The figure of the elater is copied from Rostafinski.

\section{(Rostafinski's Synonyms.)}

Jycogala contortum, Dit., in Sturm. Dent. Cr. Fl., t. 5 (1817).

Trichic reticulata, b., Grev. Sc. Cr. Fl., t. 266 (1827).

Perichaena contorta, Fr., S. M., iii., 192 (1829).

Iicea contorta, Wallr., Fl. Cr. Germ., n. 2110 (1833).

Hemitrichia contorta, Rost., ap Fckl. Syn., 2, Nach., p. 75 (1873).

\section{Trichia subfusca, Rex. :}

Sporangia stipitate, simple, very rarely double or triple, generally exactly spherical, exceptionally globose-turbinate, about $\frac{1}{2}-\frac{2}{3}$ of a $\mathrm{mm}$. in diameter. Colour of sporangia, a dull tawny brown above, shading to a dark brown at the base. Stipes uniform in diameter, and equal in height to the diameter of the sporangium, brown or brownish-black in colour, longitudinally rugose and separated from the eavity of the sporangia by the internal layer of the sporangium wall. Spores and capilitium soncolourous, of a bright yellow colour in mass.'

Elaters cylindrical $3 \cdot 5-4 \mu$ in diameter, terminating generally in a smooth elongated end $10-12 \mu$ long, which is either sharp or blunt, straight or curved to one side. Spirals four in number, non-spinulose, winding more or less unevenly, with interspaces as wide or wider than the thickness of the spirals. Spores $11.5-12.5 \mu$ in diameter, delicately but distinctly warted.

Adirondack Mts., New York.

This Trichia is more nearly allied to some of the forms of Tr. fragilis than to any other species. There seem, however, to be sufficiently well-marked specific differences. In addition to the different external characters, the elaters are undoubtedly cylindrical in a majority of the specimens. Occasionally individual sporangia are found in which the elaters are a little thicker in the centre, narrowing slightly toward the ends, but even these exceptions terminate abruptly in the same form of ends as the true cylindrical elaters. Occasionally also, as with 
all Trichias, sporangia will be found in which the elaters are branched or distorted, or have a tendency to bulbous expansions near the ends or in their course, but these are abnormal and exceptional. The specimens distributed under this number (2495) were collected in August 1889, with a few exccptions. The unusually wet season had the effect of rendering many of them much darker in colour than is indicated in the foregoing specific diagnosis, which was drawn from types developed and collected under the most favourable conditions. (Rex.)

Trichica subfusca, Rex, Proc. Acad. Sci. Phil., 1890, p. 192.

Exsicc.-Ellis and Everh., N. Amer. Fung., n. 2495.

Trichia reniformis, Peck.

Sporangia gregarious or clustered, sessile, subglobose or reniform, small, brown ; flocci few, short, sparingly branched; spores globose, minutely echinulate, yellow-ochre, sometimes tinged with green, $\cdot 0005$ in. in diameter $(=12-13 \mu)$.

Peck, 26th Report of the State Mluseum, New York, p. 76; Sacc., Syll., no. 1510 ; Mass., Rev. Trich., p. 337.

United States.

I am not acquainted with the present species, and the information given by Peck is too scanty to insure future identification.

\section{$\S \S$ Spirals spinulose.}

Trichia erecta, Rex.

Sporangia stipitate, usually simple, occasionally double or triple and very rarely fasciculate, with a cluster" of $6-8$ on a single stipc. Single sporangia globose or globose-turbinate $\frac{1}{2}-\frac{2}{3}$ of a $\mathrm{mm}$. in the transverse diameter.

Colour of sporangia a dark nut-brown, which is uniform below, but checkered or broken above into irregular patches with broad septa of a bright yellow colour.

Stipes about $1 \mathrm{~mm}$. in height, rough or granular on the surface, quite thick and equal throughout their length, and dark brown in colour. Spores and capillitiun concolourous, being a bright yellow colour in mass. 
Elaters cylindrical, $3 \cdot 75-4 \mu$ in diameter, terminating in short, sharp, smooth ends 4-6 $\mu$ long. Elater spirals 4 in. number, spinulose with numerous irregular spines, coarse, winding irregularly. Adjoining spirals often united with each other by interspiral branches which run either longitudinally or obliquely in the direction of the spirals.

Spores $12-13 \mu$ in diameter, delicately warted when examined under a high power lens.

Shawangunk and Adirondack Mts., N. Y.

This Trichia is conspicuous for the checkering or areolation of the upper surface in the perfectly mature sporangia, showing a sharp contrast between the adjoining nut brown and bright yellow colours. In this respect it resembles Tr. fragilis, which sometimes exhibits in iț var. lateritia and also in one of its simple forms, a dull mottling of the colour of the upper surface of the sporangia.

Trichia erecta, Rex, Proc. Acad. Sci. Phil., 1890, p. 193.

Exsicc.--Ellis and Everh., N. Amer. Fung., Ser. II., n. 2496.

\section{Trichia Decaisneana, De Bary.}

Sporangia pyriform, brownish flesh-colour, shining, stipitate; stem red, then blackish-brown, very much plicate, equal; mass of capillitium and spores yellowish flesh-colour ; inclosed in an inner membsane connate with the outer wall of the sporangium; elaters cylindrical, inflated near the tips and ending in smooth, tapering, curved spines 3-6 times as long as elater, spirals 5-6, fcxumus, spinulose, in some cases parts of the elaters have the spirals in the form of distant ridges or wrinkles; spores delicately warted, 10-11 $\mu$ diameter.

Trichia Decaisneana, De Bary, in Rost., Mon., p. 250, figs. 219, 220 ; Schroeter, p. 112; Cooke, Myx. Brit., figs. 219, 220; Mass., Mon. Trich., p. 338.

On Jungermannia. Germany.

According to Schroeter the spores measure from 13-14 $\mu$, the elaters have 4 spirals, and are $4-5 \mathrm{~mm}$. thick. As these measurements differ from thase given by the author of the 
species, the question that naturally suggests itself is, has Schroeter had the true species in view? In Rostafinski's Monograph, fig. 220, the spirals of the elaters are represented as broad and flat, no spines are shown in the figure.

C. Spores with elongated, raiscd, flat bands not combined to form a network.

\section{$\S$ Bands not punctate.}

\section{Trichia Balfourii, Mass.}

Sporangia sessile, base broad or narrowed, crowded, hemispherical or angular from mutual pressure, clear primrose-yellow ; mass of elaters and spores deeper and duller yellow; elaters cylindrical, $9-10 \mu$ thick, sometimes swollen near the apex, which is almuptly narrowed into from $1-3$ short, smooth spines, generally more or less bent, spirals thin, not prominent, rather distant, furnished with scattered, mudimentruy spincs; spores globose, with a few broad, slightly raised, flat bands, not punctate, nor combined in a reticulate manner; $16-18 \mu$ diameter.

Trichia Balfourii, Mass., Rev. Trich., p. 339, fig. 4.

(Type in Herb., Kew.)

On wood. Cape of Good Hope.

Closely allied to $T$. Jackii, but known by the absence of punctiform markings on the raised bands of the spores. In 1. remucosa the bands on the spores are much shorter and more numerous, the elaters of the last-named species also differ in the crowded spirals without spines and the simple stout tips.

\section{Trichia sulphurea, Mass.}

Sporangia densely crowded, subdepressed, circular, angular, or reniform in outline, pale yellow, smooth, mass of elaters and spores pale lemon-ycllow; elaters cylindrical, simple, or frequently branched, especially near the tjps, $9-10 \mu$ thick, spivals croveded, not very prominent, tips not thickened, smooth, acute, straight or slightly curved, 10-14 $\mu$ long; spores globose, with numerous short, slightly raised, straight or crescent-shaped flat bands, 10-14 $\mu$ diameter. 
Trichia sulphurca, Mass., Rev. Trich., p. 339, fig. 3.

On wood. Ceylon.

(Type in Herb. Berk., Kew, n. 10906.)

A very fine, large species with sporangia up to $1 \mathrm{~mm}$. diameter, forming densely crowded patches of considerable size. Characterized by the thick cylindrical elaters with crowded spirals, and the numerous short flat bands on the spores, which look like warts under a low power. Most nearly allied to $T$. nitens, but the spores of the latter have true rounded warts, and the spirals on the elaters are further apart.

\section{$\S$ Bands with minute depressions.}

Trichia abrupta, Cooke.

Sporangia densely gregarious, sessile on a broad base, hypothallus firm, usually angular from mutual pressure, pale yellow; mass of elaters and spores orange; elaters cylindrical, 7-9 $\mu$ diameter, spirals rather distant, not prominent, with scattered, rudimentary spinules, tips usually smooth and equal in thickness to elater for a length of 8-10 $\mu$, then terminating abruptly in two or three thin, straight or curved spines 8-10 $\mu$ loing; spores globose, with numerous slightly raised, straight or curved short bands of irregular width, furnished with minute, scattcred pits, $10-16 \cdot \mu$ diameter.

Trichia abrupta, Cooke, Ann. Lyc. Nat. Hist., N. York., vol. xi., No. 12, p. 404; Conke, Myx. Brit., fig. 256 ; Mass., Mon. Trich., p. 16, f. 2 ; Sacc., Syll., vii., 1, n. 1511.

\section{(Type in Herb., Kew.)}

On wood. Britain (Ken Wood, Hampstead; Kew, Carlisle); United States.

Allied to Trichia Jackii, but distinguished by the more numerous and shorter bands on the spores and the different elaters; separated also from $T$. intermedia by the numerous hands on the spores not anastomosing, and by the absence of thin ridges parallel to the long axis of the elaters. 
Trichia Jackii, Rost.

Sporangia usually crowded, sessile on a narrow or broad base, hypothallus well-developed, circular, angular, or elliptical in shape, dull yellow; mass of elaters and spores yellow; elaters cylindrical, $5-7 \mu$ thick, tips smooth, acute, straight or a little bent, spirals not very prominent, distant, sometimes with rudimentary spinules; spores globose, with scattered, slightly clevated, irregular, broad flat bands, slightly curved or sinnous, not combined to form a network, surface of bands with minute pits, 12-15 $\mu$ diameter.

Trichia Jackii, Rost., Mon., p. 258, f. 242 ; Cooke, Myx. Brit., f. 242; Schroeter, p. 113; Sacc., Syll., vii. 1, no. 1500; Raunk., Myx. Dan., p. 69, t. 4, f. 5 ; Mass., Mon. Trich., p. 16, f. 5.

On wood and bark. Britain (Brighton, Highgate, Castle Howard, Yorks ; Glamis, N. B.); Germany ; Italy ; Switzerland ; Denmark.

Allied to Trichia abrupta, but distinguished by the fewer and longer bands on the epispore, and the undivided tips of the elaters.

Trichia intermedia, Mass. (figs. 180-182).

Sporangia subglobose, scssile on a broad base, crowded, often irregular from mutual pressure, smooth, shining, bright ochre; mass of spores and capillitium clear pale chrome-yellow; threads simple, cylindrical, $8-10 \mu$ thick, ending rather abruptly in a short, smooth apiculus, spirals rather close, not prominent, sometimes branched, with a few rudimentary scattered spinules, and conncetcd by thinner raiscd bunds running more or less parallel to the long axis of the elater; spores globose, with a few distant raised Hat flexuous bands that anastomose to form an irregular network, often leaving free ends, surface of bands with minutc depressions usually arranged in a single row, $9-11 \mu$ diameter.

Trichia intermedia, Mass., Rev. Trich., p. 341, pl. v., fig. 1.

(Type in Herb., Kew.)

On trunks. Scarborough, Epping Forest; Finland. 
The spores somewhat resemble those of Trichia Jackii, Rost., but are smaller; the raised bands are narrower and anastomose irregularly, and the minute depressions more constantly arranged in a single row. Agreeing, with Trichia chrysosperma, Rost., in having the spirals on the elaters connected by ridges, but at once distinguished by the bands on the spores being furnished with minute depressions. I was at one time led to believe, from examination of a specimen supposed to be authentic, communicated by Mr. H. Wingate, of Philadelphia, who received it from the author, that the present species was synonymous with Trichia proximella, Karst., but a second authentic specimen of the last-named species agrees with the characters given by Karsten, hence $T$. intermedia will remain as a distinct species.

Var. persimilis, elaters very much and irregularly branched, branches usually short, and as thick as the elaters; rest as in typical form.

Trichia persimilis, Karst., in Not. Sällsk. pro Faun. et Flor. Fenn., Förh., 1868, ix., p. 353 ; Karst., Myx. Fenn., p. 139; Sacc., Syll., n. 1506 ; Mass., Rev. Trich., p. 338.

On wood. Finland.

An authentic specimen from the author proves the present form to be a variety, or more probably an abnormal form, of the present species.

D. Spores with raised flat bands combined to form a network.

* Bands plain.

Trichia chrysosperma, Rost.

Sporangia crowded or scattered, sessile, base broad or narrow, yellow or ochraceous cinuamon; mass of elaters and spores bright primrose-yellow; elaters cylindrical, $5-7 \mu$ thick, tips short, smooth, straight or curved, spirals not very prominent, rather distant, sometimes with a few scattered spinules, connected by thin ridges running parallel to the long axis of the elater; spores globose, with deep, narrow raised bands combined to form an irregular polygonal network; surface of bands not punctate, 12-14 $\mu$ diameter. 
Trichia chrysosperma, Rost., Mon., p. 255, figs. 209, 213, 240 ; Cooke, Myx. Brit., p. 65, figs. 209, 213, 240 ; Schroeter, p. 113; Sacc., Syll., vii., 1, n. 1498 ; Raunk., Myx. Dan., p. 69, t. 4, f. 1; Mass., Mon. Trich., p. 17, f. 10.

Exsicc.-Rab., Fung. Eur., n. 567.

On wood, bark, moss, \&c. Britain (Highgate); Germany.

A rare species, characterized by the deep narrow ridges forming a network on the epispore and the surface of the bands not being punctate, and by the narrow, raised lines running parallel to the long axis of the elatcrs.

It is amazing how Rostafinski managed to give so many synonyms for the present species, considering that the specific characters require for their elucidation at least a $\frac{1}{1}$ th oil immersion objective, yet this is done, and without any query as to their accuracy, although presumably not many of the types, if indeed any, were forthcoming.

\section{(Rostafinski's Synonyms.)}

Lyycoperdon gregarium, Retz. Obs., i., 33 (1769).

Iyeoperdon favogineum, Batsch., f. 173 (1786).

Strmonitis pyrifonmis, Roth. Fl. Germ., i., 548 (1788).

Splucerocerpus chrysospermus, Bull., t. 417, f. 4 (1791).

Stemonit is furogincu, Gmel. Sys., 1470 (1791).

Trichiu nitens, Pers. Obs., i., 62 (1796).

T'vichin furoginen, Pers. Disp., 10 (1797).

Trichia chrysosperma, DC. Fl. Fr., 673 (1805); Eng. Fl., v., 320; Cooke, Hdbk., No. 1187 ; Fung. Britt., ii., 524, 527.

Trichice turlinata, Purt. Brit., ii., 1115 (1817).

Clethiroides fluvescens, Hall. t. 1, f. 7 (1742).

Trichiu, Hall, 2168, t. 48, f. 7 (1768).

Lycoperdon aggregatum, Retz. Fl. Scan., 1627 (1769).

Lycoperdon epiphyllum, Light. Fl. Sc., 1069 (1777).

Clathrus turbinatus, Huds. Fl. Ang., 632 (1778); Bolt., t. 94, f. 3.

Trichia pyriformis, Vill. Fl. Dauph., 1060 (1789).

Stemonitis pyriformis, Pers., in Gmel. Sys., 1468 (1791). 
Trichia turbinate, With. Arr., iv., 480 (1792); Sow., t. 85;

Eng. Fl., v., 320; Cooke, Hdbk., 1186.

Trichia pyriformis, Pers. Disp., 10 (1797).

Trichia olivacea, Pers. Obs., i., 62 (1796), in part.

Trichia ovata, Pers. Obs., ii., 35 (1796); Schum. Saell., 1454;

Fl. Dan., t. 1313, f. 1.

Trichia vulgaris, Pers. Obs., ii., 32 (1799).

Physarum contextum, Spr. Sys., ix., 20 (1817).

Trichia verrucosa, Berk.

Sporangia pyriform, brown or chestnut', shining, passing downwards into a long, slender stem, simple or botryoid, scattered, springing from a thick, broadly effused hypothallus; mass of capillitium and spores ochraceous; threads of capillitium not branched, cylindrical, 8-10 $\mu$ thick, with smooth, tapering tips of variable length, and straight or curved, spirals close, thin, not prominent; spores globose, with narrow, raised flat bands combined into a few large, irregular, polygonal meshes, bands not punctate, 14-16 $\mu$ diameter.

Trichia verrucosa, Berk., Flor. Tasm., p. 269 ; Mass., Rev. Trich., p. 343, fig. 9 .

(Type in Herb. Berk., Kew, n. 10906.)

On wood. Tasmania.

Differs from T. chrysosperma and T. dietyospora in the scattered sporangia springing from a stout hypothallus, and also in the characters of the elaters and spores. From 2-3 $\mathrm{mm}$. high. Usually not more than one complete polygon is present on a hemisphere of the spore.

\section{Trichia Kalbreyeri, Mass.}

Sporangia crowded, sessile, often irregular from mutual pressure, pale yellow, smooth; mass of capillitium and spores pale primrose-yellow; threads of capillitium cylindrical, $9-10 \mu$ thick, with short, smooth, tapering ends, spirals not prominent, thin, elose ; spores globose, with raised, narrow flat bands forming an irregular, polygonal network, bands not punctate, $11-14 \mu$ diameter. 
Trichica Kalbreyeri, Mass., Rev. Trich., p. 344, fig. 8.

On wood and living leaves. New Granada.

Externally resembling $T$. chrysosperma, but known by the absence of ridges between the spirals, and the bands forming more numerous polygons, $2-3$ complete ones being present on a hemisphere of the spore.

\section{Trichia scabra, Rost.}

Sporangia gregarious or scattered, attached by a broad base to $a^{\circ}$ hypothallus, circular or irregular from mutual pressure, varying from pale yellow, through dirty orange to brown; mass of claters and spores clear orange; claters cylindrical, $6-8 \mu$ thick, ending in smooth, acute, straight or slightly bent tips $7-10 \mu$ long, spirals not very prominent, rather distant, bcaring numerous short, acute, straight spincs; spores globose, covered with a very fine network of raised lincs, $8-12 \mu$ diameter.

T'vichice scabra, Rost., Mon., p. 258, figs. 214-217, 239; Cooke, Myx. Brit., figs. 214-217, 239; Mass., Mon. Trich., p. 13, fig. 13 (spore incorrectly drawn with a warted instead of a very delicately reticulated epispore); Schroeter, p. 113; Sacc. Syll., vii., n. 1500 ; Raunk., Myx. Dan., p. 68, t. 4, f. 2.

Trichice scebru, v. aurca, Cke., Myx., U. States, Ann. Lyc. Nat. Hist., N. York., v. xi., No. 12, p. 403.

Exsicc,-Roum., Fung. Gall., 1005; Ellis and Everh., N. Amer. Fung., 2100.

On wood, moss, \&c. Britain (Queen's Cottage Grounds, Kew, Birminghain; Taunton, Notts; Scarboro'; Carlisle); France; Germany; Denmark; U. States; Ceylon; Australia.

Var. anclogic. Spores on spirals of elaters rudimentary or absent.

Cke., Myx., U. Statès, Ann. Lyc. Nat. Hist., N. York, vol, xi., No. 12, p. 403.

Britain (Carlisle); U. States.

Trichia fallax, Rost.

Sporangia pyriform, stipitate or subsessile, ochraceous, sometimes tinged olive, dull or shining; stem dark, usually longi- 
tudinally wrinkled, filled with large, globose, subangular cclls which become smaller uproards and pass into normal spores; elaters pyriform, simple or branched, $5-6 \mu$ thick, ending in long, smooth, tapering tips, spirals rather close, thin, not prominent; spores globose, epispore, covered with a very fine, irvegular network, 10-12 $\mu$ diameter.

Trichia fallax, Rost., Mon., p. 243, figs. 211, 221, 222, 233236 ; Cke., Myx. Brit., p. 61, figs. 211, 222, 233-236; Sacc., Syll, vii., 1, n. 1493; Mass., Mon. Trich., p. 8, figs. 21 and 27 (the spores incorrectly represented as warted instead of being delicately reticulated); Schroeter, p. 111; Raunk., Myx. Dan., p. 66, t. 4 , f. 4 .

Exsicc.-Fuckel; Fung. Rhen., 1435 ; Jack, Leiner u. Sitz., 420 ; Rab., Fung. Eur., 1666; Mong. and Nest., 284; Roum., Fung. Sel. Gall., 42.

On rotten wood. Britain (Bristol, Kew, King's Cliffe, Norths ; Carlisle, Scarboro', Linlithgow, Glamis, N. B.); France ; Germany; Switzerland; Denmark; United. States; Cuba; Venezuela.

Distinctly marked amongst the species with fusiform elaters by the stem being filled with large cells, and the very delicately and minutely reticulated spores.

(Rostafinski's Synonyms.)

Mucor capitulis pyriformis, Fl. Dan., t. 647; f. 2 (1770).

Mucor miniatus, Jacq. Misc., t. 299 (1778).

Stemonitis flavescens, Schrank., p. 19 (1792).

Iycoperdon aggregatum, Liljeb. Fl. Scan., 460 (1792).

Iycoperdon musillum; Hedw. Abh., t. 3, f. 2 (1793).

Trichia fullax, Pers. Obs., iii., t. 4, 5 (1797); Nees, f. 113;

Corda Ic., iv., 97 ; Eng. Fl., v., 319 ; Cooke, Hdbk., 1182.

Physarum pyriforme, Schum. Saell., 1448 (1803).

Trichia virescens, Schum. Saell., 1459 (1803).

Trichia eerina, Ditm., t. 25 (1817); Curr. Micr. Journ., v.,

p. 127 ; Cooke, Hdbk., No. 1184.

Trichia fulva, Purt. Mid. Fl., 1534 (1817).

Trichia clavata, Wigand, No. 3 (1863). 
Trichia furcata, Wigand, No. 4 (1863).

Arcyria clongata, Bong. Herb.

* Bands with ninute depressions on the surface.

Trichia affinis, De Bary.

Sporangia clustered, circular or elliptical, sessile on a broad base, seated on a distinct hypothallus, clear pale yellow; mass of elaters and spores pale yellow; elaters cylindrical, 4-6 $\mu$ thick, ending in short, tapering, smooth tips, spirals thin, rather close, not prominent, sometimes with short spinules; spores globose, with broad, slightly raised flat bands combined into a network, or sometimes with free ends, surface of bands pitted, 10-14 $\mu$ diameter.

Trichic affinis, Rost., Mon., p. 257, f. 241 ; Cke., Myx. Brit., f. 241 ; Schroeter, p. 113 ; Sacc., Syll., n. 1499 (?); Mass., Mon. Trich., p. 20, f. 7.

On wood, twigs, moss, \&c. Britain (Epping, Brandon, Scarboro', Castle Howard, Yorks; Carlisle, Appin, N. B.); Europe; United States; Cuba; Australia; Tasmania.

Superficially resembling $T$. chrysosperma, distinguished by the presence of pits on the raised bands of the epispore, and the absence of raised ridges running parallel to the long axis of the elater.

\section{Trichia superba, Mass.}

Botryoud, rarely.simple. Sporangia broadly obovate, pale yellow, common stem more or less wrinkled longitudinally, often twisted, colour of the sporangium above, becoming orange downwards, springing from a well-developed hypothallus; mass of capillitium and spores deep yellow; elaters simple, cylindrical, 9-11 $\mu$ thick, with abruptly tapering, smooth, short ends, often more or less bent, spirals close, thin, but little prominent; spores globose, with raised flat bands combined into a polygonal nctwork; bands with a ronv of minute depressions, 17-20 $\mu$ diameter.

Trichia supcrba, Mass., Rev. Trich., p. 345 f. 6. 
(Type in Herb., Kew.)

On mosses and logs. New Zealand.

Scattered, 3-4 mm. high, stem about equal in length to the sporangium, thin and weak, so that the sporangia are often drooping. Allied to $T$. affinis, bat distinct in the much larger spores, with smaller and more numerous reticulations, and the stipitate, obovate sporangia usually arranged in a botryoid manner.

\section{Trichia Kickxii, Rost.}

Sporangia spherical, sessile, in several crowded strata, forming cakes some $\mathrm{mm}$. high, and sometimes $\mathrm{cm}$. long and broad; walls of single sporangia rigid, flesh-colour, polished and shining; elaters simple, either flexuous or curved into circles, $4 \cdot 2 \mu$ thick, spirals two, not very prominent; tips obtuse; spores with an irregular network, 14-15 $\mu$ diameter.

Trichia Kickxii, Rost., Mon. App., p. 40; Sacc., Syll., vii., 1, n. 1504; Mass., Rev. Trich., p. 345.

I have no knowledge of the present species except from Rostafinski's diagnosis, which strongly suggests to my mind a species closely allied to Oligonema nitcns.

\section{Trichia pusilla, Schroeter.}

Sporangia subglobose, very small, $0.3-0.5 \mathrm{~mm}$. diameter, gregarious, scattered or collected in clusters, golden or brownishyellow, smooth, shining, fragile; hypothallus absent; elatcrs very short, about $100 \mu$ long, 4-5 $\mu$ thick, here and there thickened, apices rounded, often mucronate and curved, spirals 2-3, slightly prominent, here and there inconspicuous; spores globose, unequally costulato-reticulate, $11-12 \mu$ diameter.

Trichia pusilla, Schroeter, p. 114; Sacc., Syll., vii., 1, n. 1509 ; Mass., Rev. Trich., p. 345.

On bark. Germany.

\section{LITHODERMEAE.}

The most pronounced characteristic of the present section is the almost universal presence of carbonate or rarely bicarbonate 
of lime in the form of crystals, or more frequently as minute amorphous particles. In the sub-section Physarce, which includes the terminal inembers of the section, lime is present in very considerable quantity both on the sporangium and in the threads of the capillitium, whereas in the sub-section Didymcae lime is abundant on the sporangium, but absent from the capillitium, although usually present in the columella when the latter is present. The genus Cratcriachea is intermediate between the two sub-sections as regards the disposition of lime. In the genus Diachace lime is absent from the sporangium, although present in quantity in the columella and stem; this genus, as explained later on, forms a connecting link between the present section and the Columelliferce, and as such, does not come within the diagnosis of either. Owing to rigidity due to the abundance of lime, especially in the sub-section Physcurcec, there are no marked contrivances for spore dispersion, which appears to be effected by wind on the dissolution of the sporanginm, but in the Didymcae, where the capillitium is free from lime and possesses a certain anount of elasticity, the sporangium frequently dehisces in a definite manner.

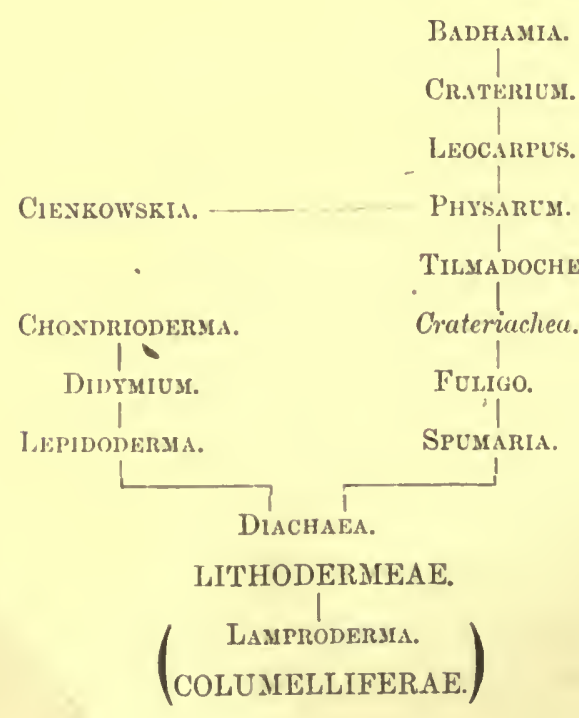




\section{ANALYSIS OF THE GENERA.}

\section{Sect. LITHODERMEAE.}

Sub-sect. DidymeaE.

Chondrioderma. Sporangia with a continuous porcelainlike coat of lime.

Didymum. Sporangia with a pulverulent, crystalline coat of lime.

LEPIDODERMA. Sporangia with isolated, large patches of lime.

SpUmaria. Aethilium consisting of sporangia arranged in a dendritic manner.

Diachaea. Sporangia iridescent, without lime.

\section{Sub-sect. Physarae.}

BADHAMIA. Threads of capillitium thick, containing lime throughout their length.

Craterium. Sporangia with a well differentiated lid, or splitting in a circumscissile manner.

Physarum. Capillitium with numerous large, irregular nodes containing lime, and connected by thinner portions without lime.

Tilmadoche. Capillitium with small, scattered, elliptical nodes containing lime internodes thin, elongated, without lime.

Leocarpus. Sporangia obovate, polished.

Ceinkawskia. Capillitium with curved, free tips.

Crateriachea. Columella present; threads of capillitium mostly without nodes, containing lime.

Fuligo. A cake-like aethalium.

\section{Sub-sect. Didymeae.}

ChONdrioderia, Rost. (in part).

Sporangium stipitate or sessile, wall single or double, outer wall charged with lime, perfectly smooth, porcelain-like, dehis- 
cing irregularly or in a stellate manner; inner wall, when present, very thin, containing no lime, often iridescent; columella present or absent; threads of capillitium thin, without lime; either sparingly bifurcating, or branching and anastomosing to form a more or less dense net.

Chondrioderma, Rost., Mon., p. 167; Cooke, Brit. Myx., p. 36; Schroeter, p. 123; Sacc., Syll., v., 7, pt. I, p. 362.

The characteristies of the present geuus are, a well-developed capillitium not containing lime, and the outer wall highly charged with lime, externally perfectly smooth and porcelainlike. Closely allied to Didymium; in fact so closely allied, that leaving out imaginary or book distinctions, the only point of difference consists in the outer surface of the wall in Didymium never being porcelain-like, but always more or less granular or pulverulent. Such a division is convenient from the systematic point of view, as to whether it is of generic value or not is a question that cannot perhaps be decided in the present state of knowledge as to what constitutes affinity in the Myxograstres. The space between the outer and inner wall I do not find sufficiently constant to adopt as part of the generie character, its presence depends on the contraction of the spore forming mass of protoplasm, due to expulsion of water after the outer caleareous wall has become rigid ; in C. sublateritium, the contraction of the inner spore-mass takes place before the outer calcareous wall becomes rigid,- hence the latter also collapses and becomes normally umbilieate above. 'T'he same condition of things may sometimes be met with in species that usually have a space between the two walls.

Distrib. Temperate and tropical regions; most abundant in the former. Species 34 .

Sub-Gen. Leangium. Sporangium splitting in a stellate manner.

A. Columella present.

Chondrioderma floriforme, Rost. (figs. 58, 59). Liderma flor

Gregarious, springing from a well-developed hypothallus; sporangia broadly obovate, stipitate, yellowish-brown, dehiscing 
in a stellate manner, the lobes becoming reflexed; stem longer than height of sporangium, equal, minutely longitudinally rugulose, erect, colour of sporangium; columella clavate, stipitate, rugulose above, pale brown or ochraceous; mass of spores blackish with purple tinge; threads of capillitium brownish-purple, $3 \mu$ thick, branching at acute angles and combining laterally to form an irregular network, furnished with irregular thickenings; spores globose, dingy violet, with a few rather large conical warts, $10-12 \mu$ diameter.

Chondrioderma floriforme, Rost., Mon., p. 184 (excl. syn. Diderma concinnum, B. and Br., added by Rostafinski in Mon. Append.); Cooke, Brit. Myx., p. 41 ; Sacc., Syll.; n. 1285 (excl. syn. Didcrma concinnum, B. and Br.); Raunk., p. 84 .

Exsicc.-Ellis, N. Amer. Fung., 1121; in Fuckel, Fung. Rhen., 2496, the specimen agrees in every respect with the above description except that the spores are almost smooth. Rostafinski describes the spores as having scattered spines, which is translated by Cooke, Myx. Brit., p. 41, as "rarely spinulose," and the description in Saccardo's "Sylloge" is a translation of Cooke's version, hence incorrect.

On decaying wood. Britain (Queen's Cottage Wood, Kew; Grace Dieu, Leicester); Germany; France; Denmark; United States.

About $2.5 \mathrm{~mm}$. high, sporangia polished, wall thick; superficially resembling some stipitate forms of Lepidoderma radiatum before dehiscence, but the latter is distinguished by the stem being much attenuated towards the base.

\section{(Rostafinski's Synonyms.)}

Sphaerocarpus floriformis, Bull., t. 371 (1791).

Stcmonitis floriformis, Gmel., Syst., 1469 (1791).

Iycoperdon floriforme, Witl., Arr., iv., 379 (1792).

Reticularia floriformis, Poir., Ency.

Didymium floriforme, Schrad., N. G., 25 (1797).

Diderma floriforme, Pers. Syn., 164 (1801); Fr., S. M., iii., p. 99 ; Berk., Engl. Flora, v., p. 310 ; Cooke, Hdbk., No. $110 \check{.}$ 
Chondrioderma radiatum, Rost. (figs. 92-95). D d rra rad

Sporangia stipitate or sessile, subglobose or depressed, umlilieate bclonv, pallid or with a brown tinge, when mature splitting in an irregularly stellate manner from the apex, segments reflexed, persistent; stem, when present, shorter than sporangium, attenuated downwards; columella large, globose or slightly clongated, mugulose, pallid or with a rufous tinge; threads of capillitium thin, fuliginous, or almost colourless, simple below, then bifurcating at acute angles, now and then combining laterally; spores globose, violet-brown, minutcly wartcl, $9-12 \mu$ diameter.

Chondrioderma radiatum, Rost., Mon., p. 18:, figs. 152, 153, 155, 156, 170 ; Cooke, Myx. Brit., p. 40, figs. 152, 153, 155, 156, 170 ; Schroeter, p. 125.

Diderma stellare, Fries. Seler. Succ. Exs.

On wood, bark, \&c. Britain (King's Cliffe, Scarboro'); Sweden; Germany; Denmark; France; United States.

Sporangia scattered or loosely gregarious, about $5 \mathrm{~mm}$. diameter before dehiscence. Recognized amongst the species that dehisce in a stellate manner by the umbilicate sporangium, which is constant when the specimens are sessile, the large rugulose pale columella, and the minutely warted spores.

\section{(Rostafinski's Synonyms.)}

Lycopierdon vadiatum, Linn., sp., 1654 (1753).

Didymium stcllare, Schrad., t. 5, f. 3, 4 (1797).

Dilcrma stellare, Pers. Syn., 16+ (1801).

Didcrma umlilicatum, Pers. Syn., 165 (1801); Eng. Fl., v.,

310 ; Ckc., Hdbk., No. 1106.

Dirlcrnna crussipres, Schum. Saell., 1421 (1803).

Reticularia umbilicata, Poir., Ency.

Didymium gerester, Link, diss. ii., 42 (1809).

Leangium stellare, Link, diss. ii., 42 (1809).

Cionium stellure, Spr. Syst., iv., 529 (1827).

Cionium umbilicatum, Spr. Syst., iv., 529 (1827).

Leangium umbilicatum, Rabh. Fl. Crypt., 285 (1844).

Dilymium complanatum, Fck]., Sym. Myc., $3+1$ (1869). 
Chondrioderma geasteroides, Phil. Aiderma Trevelya xi Tr.

Sporangia sessile or shortly stipitate, globose or broadly pyriform, ochraceous-brown, polished, dehiscing in a stellate manner into five or six unequal, acute segments which become strongly reflexed, inner surface of wall white, rough with granules of lime; stem, when present, shorter than sporangium, thick, obscure brown; columella globose, ochraceous-trown; threads of capillitium brownish or almost colourless, repeated branching in a dichotomous manner, and anastomosing laterally to form a network; base of ecueh bifurcation swollen and darkcoloured; spores globose, brown, minutely: wartecl, 11-14 $\mu$ diameter.

Chondriodcrma gecsteroides, Phil., in Herb.

Diderma geasteroides, Phil., Grev., v., 5, p. 113, t. 87, fig. 1, a-f; Sacc., Syll., 1293.

Diderma laciniatum, Phil., Grev., v., 5, p. 113, t. 87, fig. 2, a-f; Sacc., Syll., n. 1294.

(Types in Herb., Phillips.)

On rotten wood, mosses. \&c. California.

For an opportunity of examining the present and other types of Myxogastres from California, I am indebted to the kindness of Mr. Wm. Phillips, F.L.S., of Shrewsbury.

Gregarious or scattered, $\frac{2}{3}-1 \mathrm{~mm}$. high. After dehiscence the present species is a very beautiful object under a low power, the snow-white inner surface of the reflexed segments standing out in contrast to the purple-black mass of spores, and the ochraceous-brown or fulvous outside colour. Distinct from $C$. radiatum, its nearest ally, in the peculiar structure of the capillitium and the colour and coarsely granular inside of the sporangial wall, the spores are also larger in the present species.

Chondrioderma Lyallii, Mass. (n. sp.). Dider ma niversm Macbr

Scattered or aggregated; sporangia globose or broadly obovate, var. Lyallii.h stipitate, wall thick, polished, whitish or pallid, splitting in an irregularly stellate manner; stem shorter than sporangium, 
thick, irregularly rugulose, expanding at the base into a small hypothallus, pale ochraceous; columella cylindraceo-clavate, nearly half the height of the sporangium, smooth, pallid; mass of spores blackish-violet; capillitium copious, threads dingy lilac, $3-3 \cdot 5 \mu$ thick at the base, tapering, branching irregularly and anastomosing laterally, furnished with numerous elongated swellings usually containing a few dark granules; spores globose, deep violet, almost opaque, coarsely warted, 13-15 $\mu$ diameter.

On thin decorticated twigs. Fort Colville, Canada. (Dr. Lyall.)

\section{(Type in Herb., Kew.)}

From 1.5-2 mm. high, with the habit of Chondrioderma Oerstcdii, differing in the highly developed colimella and irregular mode of dehiscence.

Chondrioderma Carmichaelianum, Cooke (figs. 245-247). Diderv a va

Sporangia spherical, quite sessile, splitting when mature into 4-5 acute segments, pale red, polished; columella sphericat, attenuated at the base, pale rol; threads of capillitium very thin, colourless, branching in a dichotomous manner, here and there laterally connected; spores globose, dark-violet, smooth, $11-13 \mu$ diameter.

Chondrioderma Carmichacizanum, Cooke, Myx. Brit., p. 42.

Chondrioderma radiatum, Rost., Mon, Append., p. 40 (in part); Sacc., Syll., 1284 (in part).

Diderma Carnichaelianum, Berk., Eng. Fl., vol. v., p. 34; Cooke, Hdbk., no. 1112.

(Type in Herb. Berk., Kew.)

On moss. Britain (Appin, N. B. ; Trifreu, Wales).

Sporangia about $5 \mathrm{~mm}$. diameter; distinguished from $C$. radiatum in being sessile and globose, not umbilicate below, and in the smooth spores.

Chondrioderma Trevelyana, Rost. Diderma Trevelyani

Sporangia ovate or subglobose, sessile, wall single, polished ivory coloured, splitting half way to the base into numerons 
narrow segments which become reflexed; columella white, minute; mass of spores blackish-purple; capillitium dense, threads colourless, $2-3 \mu$ thick, frequently forking at a wide angle, and combined laterally to form a net, slightly thicker at the point of bifurcation; spores globose, minutely verruculose, $12-14 \mu$ diameter.

Leanginum? Trevelyani, Grev., Scot. Cr. Fl., pl. 132.

Chondrioderma Trevelyana, Rost., Mon., p. 182, figs. 161-163; Cooke, Brit. Myx., p. 40, figs. 161-163; Sacc., Syll., n. 1289.

In the Appendix to Rostafinski's Monograph, the present species is referred as a synonym to Chondrioderma radiatum.

On living leaves of Bryum ligulatum. Britain (Northumberland).

Sporangia scattered; 1-15 min. diameter before dehiscence. The above description is drawn up from a specimen originally in Sowerby's Herbarium, and now in the Berkeley: Herbarium, Kew, and said to be from Greville. It is certainly quite distinct from C. radiatum, in the greater number of segments (14-16) into which the sporangial wall splits, the colourless capillitium, and larger spores.

(Rostafinski's Synonyms.)

Leangium (?) Trevelyani, Grev., Scot. Cr. Fl., t. 132 (1825).

Cionium Trevelyani, Spr., Syst., iv., 529 (1827).

Diderma Trevelyani, Fr., S. M., iii., 105 (1829); Eng. Fl., v.,

311 ; Cooke, Hdbk., No. 1111.

Polyschismium 'Trevelyani, Corda, Icon., v., p: 20 (1842).

\section{B. Columella absent.}

Chondrioderma Oerstedtii, Rost. (figs. 87, 88). Diderma Treurlyani F

Sporangia stipitate, subglobose or broadly pyriform, when mature splitting in a stellate manner into 4-6 irregular, acute segments, pallid; stem short, usually darker than sporangium; columella entively absent; threads of capillitium colourless or dirty-lilac, combined to form a net, often furnished with darker 
thickenings; spores globose, violet, densely covered with minute warts, $10-14 \mu$ diameter.

Chondrioderma Oersteiltii, Rost., Mon., p. 184, figs. 154, 157 ; Cooke, Brit. Myx.," p. 41, figs. 154, 157; Sacc., Syll., 1286; Grev., vol. v., p. 12.

(Specimen named by Rostafinski in Herb. Berk.)

On wood, \&c. Britain (Jedburgh); Gernıany.

I have not been able to observe the glistening glassy warts described by Rostafinski as present on the sporangium. Distinguished from C. radiatum by the absence of columella, and from C. Carmichaclianum in the presence of a stem.

Chondrioderma lucidum, Cooke. Dider ina lucidum $B_{4}$ r

Sporangia subglobose, sessile, either scattered or crowded, splitting in an irregular stellate manner, bright reddish-yellow; internally yellow, mass of spores globose; capillitium brown, irregular at the points of ramification, yellowish, spores globose, violet-black, $\cdot 0125 \mathrm{~mm}$. ( = $12 \mu)$ diameter, minutely echinulate.

Chondrioderma lucidum, Cooke, Myx. Brit., p. 42; Sacc., 1288.

Diderma luciulum, B. and Br., Ann. Nat. Hist., n. 938, t. 15, fig. 9 ; Cke., Hdbk., n. 1110.

On moss and Jungermunnia. Britain.

I have seen no specimen of the present, species.

According to Berkeley's figure the sporangium is sometimes furnished with a short, distinct stem thickened upwards, the sporangium may be spherical or considerably depressed; after dehiscence the basal portion is persistent with an irregularly toothed margin; an "obscure columella" is also present. May not this be a form of $C$. radiatum?

Sub-Gen. Chondrioderma. Sporangium irvegularly ruptured.

A. Columella present.

Chondrioderma Michelii, Rost. (fig. 312). Liserma hemispheri

Sporangia springing from a well-developed more or less torn hypothallus, stipitate or almost sessile, circular in outline, 
discoid, thin, fat or slightly convex above, rather concave below, white or cream-coloured; the wall breaking away in irregular patches above; stem equal, pale ochruceous or whitish, longitudinally wrinkled, the ridges continuing on the under side of the sporangium; in some specimens the stem is obsolete, and a broadly extending plasmodiocarp, forming continuous patches, or an irregularly branched anastomosing structure is produced; columella fattcned, dingy red; mass of spores black with purple tinge; threads of capillitium $1-2 \mu$ thick, pale or colourless, forked, combining laterally to form a loose net; spores globose, dingy lilac, smooth, 8-9 $\mu$ diameter.

Chondrioderma IFichelii, Rost., Fckl., Symb. Myc., Nach. 2, p. 74; Róst., Mon., p. 172, figs. 131; 146, 149, 150; Cooke, Brit. Myx., p. 37, figs. 131, 146, 149, 150 ; Sacc., Syll., n. 1268 ; Schroeter, p. 123.

Didymium Michelii, Lib., Pl. Crypt. Ard., Fasc. II., no. 180 (1832).

Exsicc.-Lib., Pl. Crypt. Ard., Fasc. II., n. 180; Fuckel, Fung. Rhen., 2691 ; Ellis, N. Amer. Fung., 61 5.

On living or dead leaves, twigs, wood, \&c.; some of the specimens were found on horse-dung. Britain (specimen from Sowerby's Herbarium; Appin, N. B.); Sweden; Germany; France; Belgium; Italy; United States; India.

Sporangia $1-1.5 \mathrm{~mm}$. diameter. Resembling an Agaric in miniature; the stem is sometimes obsolete, and then the sporangia frequently coalesce in series of three or four. In the Indian form there is a very thin ochraceous inner pellicle without lime; in every other respect it agrees with the typical state of the plant.

\section{(Rostafinski's Synonyms.)}

Diderma contortum, Hoffm., t. 9, f. 2 a (1795).

Reticularia contorta, Poir., Ency., vi., 182.

Reticularia hemispherica, Sow., t. 12 (1797).

Physar"um depressum, Schum. Saell., No. 1439 '(1803); Fl. Dan., t. 1972, f. 2. 
Diderma physarioides, Schum., Herb.

Diderma depressum, Fr., S. M., iii., 108 (1829).

Diderma lenticulare, Wallr., Herb.

Didymium Michelii, Lib., Exs. ii., 180 (1832).

Didymium hemisphericum, Berk., Engl. Fl., v., p. 312 (1836);

Cke., Hdbk., No. 1119.

Chondrioderma globosum, Rost. Diderma qlubosum Pes

Sporangia globose, seated on a broad or narrow base, hypothallus strongly developed, chalk-white, containing much lime, outer wall thick, white, at length irregularly ruptured; inner wall cinereous, often iridescent; columella white, small, globose or ellipsoid; threads of capillitium bright violet, sometimes almost colourless, forming a dense net; spores lilac with tinge of brown, minutcly warted, $8-10 \mu$ diameter.

Chondrioderma globosum, Rost., Mon., p. 180, fig. 138; Cooke, Myx. Brit., p. 39, 40, fig. 138; Schroeter, p. 370; Sacc., Syll., n. 1278 .

On leaves, twigs, \&c. Britain (Norths); France; Gernany ; Belgium; Italy; U. States.

Sporangia often subangular from mutual pressure, $\frac{2}{3}-1 \mathrm{~mm}$. diameter. Columella pure white.

\section{(Rostafinski's Synonyms.)}

Mucilago, 7, Mich., t. 96, f. 6 (1729).

Lycogrelı, Hall., n. 2143 (1763).

Reticularia sphaeroidalis, Bull., 446, f. 2 (1791).

Diderma globosum, Pers. Disp., t. 1, f. 4, 5 (1797); Eng. Fl., v., p. 312 ; Cke., Hdbk., 1114.

Dilymium candidum, Schrad., Nov. Gen., 25 (1797).

Didymium globosum, Chev., Fl. Par., t. 9, f. 28 (1827).

Physarum sphaeroides, Chev., Fl. Par., 339 (1827).

Cionium globosum, Spr., iv., 529 (1827).

Chondrioderma niveum, Rost. (figs. 89-91). Didesma ni e w 11 Sporangia sessile, hemispherical, elliptical or irregular from 
mutual pressure, snow-white, polished, dehiscing irregularly; columella large, depressed, dirty oehraceous or brownish; capillitium dense, threads $2-3 \mu$ thick at the base, remaining for some distance simple, then bifurcating and anastomosing laterally, pale and lilac-brown; spores globose, pale lilac, very minutely verruculose, many of the warts showing a tendency to become elongated into ridges, $10-12 \mu$ thick.

Chondrioderma niveum, Rost., Mon., p. 170; Cooke, Myx. Brit., p. 37; Sacc., Syll., 1259.

(Specimen named by Rostafinski in Hb. Berk.)

On leaves, grass, wood. Britain (Linlithgow).

Scattered or crowded, $2-2.5 \mathrm{~mm}$. across.

Chondrioderma virgineum, Mass. (n. sp.) (figs. 216-220). Diderma spumar

Gregarious; regular, hemispherical, sometimes slightly depressed, sessile on a broad base, wall at first polished, snow-white, the outer film falling away in patches, grey or pulverulent below; columella snow-white, depressed, rugose, extending over the greater portion of base of sporangium; capillitium forming a dense net, threads very thin, colourless, combining at numerous points to form large, irregular, membranaceous expansions of a pale lilac colour; spores globose, pale lilac, very minutely verruculose, 8-11 $\mu$ diameter.

Chondrioderma Cookci, Mass., in Herb., Kew.

On leaves. Britain (Hampstead).

(Type in Herb., Kew.)

Densely gregarious, but not crowded, about 5 diameter. Agreeing with Chondrioderma Friesianum, Rost., in the structure of the sporangial wall, but distinct in the capillitium and spores.

Chondrioderma dealbata, Mass. Diderma subdictyo spermum

Sporangia scattered or crowded, subglobose, sessile on a broad base, sometimes seated on a white hypothallus, wall very smooth, white, fragile, dehiscing in a circumseissile manner; columella subglobose, white, sometimes almost obsolete; capillitium dense, 
threads often forked at acute angles, anastomosing laterally, brownish-lilae, furmished here and there with thickenings; spores dusky violet, globose, with prominent, elongated, flexuous vidges, 8-11 $\mu$ diameter.

"Didymium dealbatum, B. and C.," in Herb. Berk., n. 10756.

Chondrioderma subdictyospermum, Rost., Mon. Append., p. 16; Sacc., Syll., n. 1260.

On wood, amongst moss. Venezuela.

A very fine and distinct species, sporangium pure white, polished, about $5 \mathrm{~mm}$. diameter. There appears to be no good reason why Berkeley's specific name, although only a manuscript one, should have been changed by Rostafinski. The description of the present species in Saccardo's Sylloge is meaningless.

(Rostafinski's Synonym.)

Didymium decelbatum, B. msc.

Chondrioderma Friesianum, Rost. ¿ Jevv, a hemispher,

Sporangia sessile, subhemispherical, wall very much charged with lime, snow-white, after the crust has fallen away, grey; colunella distinct, lenticularly depressed, yellowish-gilvous or flesh-colour; capillitium well-developed, colourless, threads combined to form a network; spores pale violet, $8 \mu$ diameter, smooth.

Chondrioderma Euisianum, in Fuckel's Sym. Myc., 2, p. 74; Rost., Mon., p. 172; Sacc., Syll., no. 1266.

On bark, stems, \&c. Europe.

Distinguished from Chondrioderma globosum by its irregular form, by the inside of the sporangial wall subreticulate, and the almost umber spores.

\section{(Rostafinski's Synonyms.)}

Didermu difforme, Sommf., Fl. Lap., p. 217 ; non Pers; sed Fr., S. M., iii., p. 106 (1825).

Chondrioderma Friesianum, Rost., in Fuckel's Symb. Myc., 2, Nach., p. 74. 
Chondrioderma albescens, Phil. Aiderma niveum Machr.

Sporangia globose or slightly depresscd; scssile on a broad base, outer wall crustaceous, white, polished, becoming irregularly ruptured above, inner wall very thin, ochraceous towards base of sporangium and where it passes over the columella, colourless and very delicate above; columella well-developed, more or less globose, ochraccons; mass of spores blackish-purple; threads of capillitium fuliginous or almost colourless, about $3 \mu$ thick at the base, remaining for some distance simple, then branching at acute angles, towards the apices anastomosing freely to form a dense, irregular net; spores globose, lilac-brown, minutely verruculose, $10-13 \mu$ diameter.

Chondrioderma albescens, Phil., in Herb.

Diderma albescens, Phil., Grev., v., 5, p. 114, t. 87, f. 3, a-f; Sacc., Syll., 1291.

On pine bark. California.

(Type in Herb. Phillips.)

Gregarious, or towards the margin of the clusters, scattered, 1-1.5 mm. diameter. After dehiscence, when the spores, are blown away, the bright ochraceous columella and base of sporangium are very conspicuous. The threads of the capillitium are sometimes furnished with scattered swollen portions.

Chondrioderma simulans, Rost. Dider ma globosum Pers.

Sporangia spherical, narrowed at the base, adnate to a welldeveloped, chalk-white hypothallus composed mostly of lime, outer wall crustaceous, chalk-white, inner wall cinereous or variously bright-coloured; columella generally very small, chalkwhite, spherical or conical; threads of capillitium forming a dense net, with triangular protuberances at the nodes, brownishviolet; spores dingy violet, very spinulose, $12.5 \mu$ diameter.

Chondrioderma simulans, Rost., Mon. Append., p. 20 ; Sacc., Syll., 1279 .

Chondrioderma Saundersii, B. and Br. Diderma effusum Morq

Sporangia scattered, sessile on a broad base, very much 
depressed, circular in outline, wall very thin, chalk-white, polished, breaking away in irregular patches; columella flattened, white, small, mass of spores blackish-purple; threads of capillitium equal, about $2 \mu$ thick, frequently branching and combined laterally to form a dense nct; spores globose, smooth, dingy violet, $9-10 \mu$ diameter.

Chondrioderma Saundersii, B. and Br., in Herb.

(Type in Herb. Berk., no. 10744.)

On living fronds of ferns. Java.

Resembling superficially circular forms of Chondrioderma difforme, but distinguished by the columella and dense capillitium. Sporangia $2-3 \mathrm{~mm}$. diameter, outline circular, often waved; a very thin powdery layer of minute granules of lime is frequently present on the mass of spores, which then appears dark grey.

Chondrioderma affine, Rost. Liderma globuen-

Sporangia small, densely crowded on a common hypothallus, irregularly angular, depressed, surface smooth, greyish-white; columella irregular, small, white, rarely very conspicuous; threads of capillitium thin, forming a net, dirty-violet, often furnished with fusiform subviolaceous protuberances; spores subviolaceons, densely aculeate, 10-14 $\mu$ diameter.

Chondrioderma affine, Rost., Mon. App., p. 18; Sacc., Syll., 1271.

Poland; Germany; France.

Appears to be very closely allied to Didyminum spumarioides of the present work (Chondriodcrma spumarioides, Rost.); differing in the smooth surface of the sporangial wall, the dingy colour of the capillitium, and the larger, densely aculeate spores.

\section{* Sprorangium colonced.}

Chondrioderma testaceum, Rost. Diderma testace

Sporangia gregarious or crowded, sessile on a broad base, hemispherical or elliptical, rather depressed, sometimes irregular from mutual pressure, outer wall smooth, from brick-red to almost 
colourless, dehiscing irregularly, inner wall violet-grey; threads of capillitium slender, brownish-lilac or almost colourless, frequently bifurcating and anastomosing, sometimes flexuous; columella subglobose or depressed, reddish or almost colourless; rugose, spores globose, brownish-lilac, minutely verruculose, 9-11 $\mu$ diameter.

Chondrioderma testaceum, Rost., Mon., p. 179, figs. 135-136; Schroeter, p. 135; Sacc., Syll., n. 1274; Cooke, Myx. Brit., figs. 135, 136.

Exsicc.-Fuckel, Fung. Rhen., 1467; Desm., Cr. Fr., Ser. I., 706 (as Diderma testaccum); Ellis and Everh., N. Amer. Fung., 2093.

On mosses, leaves, twigs, \&c. Sweden; Germany; Finland; Hungary; United States.

Varying from $5-1 \mathrm{~mm}$. diameter; the colour of the sporangium bright brick-red, but it is sometimes much paler.

\section{(Rostafinski's Synonyms.)}

Reticularia sphaeroidalis, Var. 2, Bull. Champ., p. 94, t. 446, f. 2, D (1791).

Didymium testaceum, Schrad., p. 25, t. 5, f. 1, 2 (1897).

Diderma testaceum, Pers. Syn., p. 167 (1801).

Cionium testaceum, Spr. Syst., iv., p. 529.

Chondrioderma sublateritium, Rost. Diderma Festacevm Pers

Densely gregarious, sessile on a broad base, but rarely deformed by crowding, circular in outline, depressed, umbilicate above, pale brick-red, polishad; inner wall lead-colour; columella small, flattencd, reddish, capillitium forming a flaccid network, threads thin, sometimes flexuous, with here and there small fusiform swellings without lime; spores globose, pale lilac-brown, minutely verruculose, $9-11 \mu$ diameter.

Chondrioderma sublateritium, B. and Br., Journ. Linn. Soc., vol. xiv., p. 82.

On leaves. Ceylon. 
Closely allied to Chondvioderma testaceum, if indeed it is more than a geographical variety. Sporangia flattened, umbilicate above, frequently dehiscing in a circumscissile manner.

Chondrioderma mutabile, Schroeter. Diderme niveum

Sporangia sessile, deformed, hemispherico-depressed, or elongated and curved, reniform, semicircular, \&c., $1-3 \mu$ long, $1 \mathrm{~mm}$. broad, hard, fragile, bright, greyish-bronon; columella wcll developed, same shape as the sporangium, bright mufous-bronon; threads of capitulum thin, violet, here and there thickened in a nodulose manner; spores globose, $11-14 \mu$ diameter, blackishviolet, mucronulate.

Chorulriodemna mutulile, Schroeter, Kr. Fl., p. 123; Sacc., Syll., 1273.

On rotten wood. Silesia.

\section{Chondrioderma fallax, Rost. ?}

Sporangia spherical, sessile, ycllonvish-white, seater in numbers, but not crowded, on a distinct common hypothallus; columella either minute and flattened, or of medium size and ovate; threads fasciculate for some distance then branching copiously, obscure violet; spores obscure violet: varted, 12-14 $\mu$ diameter.

Chondrialcrma fallax, Rost., Mon., p. 171 ; Sạcc., Syll., no. 1261.

Salzburg, Tyrol.

\section{1). Columella absent.}

Chondrioderma difforme, Rost. (figs. 35-38). Did yminumal tho

Sporangia sessite on a broad base, convex, circular or irregularly elongated, outer wall snow-white, rather thick, breaking away in patches, inner wall separated from the outer by a space containing air, thin, without lime, brownish-ochre, sometimes iridescent; mass of spores blackish; columella absent or represented by a small accumulation of lime at base of sporangium, which is covered by the inner wall; capillitium scanty, sometimes almost obsolete, threads springing from base of sporangium, 
3-4 $\mu$ at base, slightly attenuated upwards, forked, pale brọn or colourless; spores globose, smooth, dingy violet, $10-13 \mu$ diameter.

Chondrioderma difforme, Rost., Mon., p. 177, figs. 137, 164, 165; Cooke, Myx. Brit., p. 39, figs. 137, 164, 165; Sacc., Syll,, 1282 ; Raunk., 83.

Chondrioderma Cubense (B. and C.), Rost., Mon. Append., .p. 19 ; Diderma Cubense, B. and C., Journ. Linn. Soc., v. x., p. 347.

Exsicc.-Lib., Pl. Crypt.:Ard., Fasc. III., 276 (as Diderma liceoides); Fckl., Fung. Rhen., 2300 (as Diderma liccoides); Rabh., F. Eur., 1423 (as Didyminm Libertianum, De Bary); Rab.-Wint., Fung. Eur., 3172; Roum., Fung. Gall., 1311 and 2956 ; Rab., Herb. Myc., 456 ; Roum., Fung. Gall., 243 (as Diderma candidum); Sydow, Myc. March., 1497; Desm., Cr. Fr., Ser. I., 370 (as Diderma difforme); Fuckel, Fung. Rhen., 1464 (as Leocarpus calcareus, Link); Ellis, N. Amer. Fung., 1217; not typical, the spores smaller than in type, and the inner wall bright grey.

On twigs, leaves, \&c. Britain (Elmsted, Kew, Northampton, Rudloe, Twycross, Carlisle, Scarboro', Linlitbgow, Appin, N. B.); France; Germany; Switzerland; U. States; India; Australia.

Sporangia 1-2 $\mathrm{mm}$. across when circular, hemispherical in section.

(Rostafinski's Synonyms.)

Reticularia angulata, Pers. in Gmel., p. 1472 (1791).

Diderma difforme, Pers. Disp., p. 9 (1797); Icon. Pict., t. 12, f. 3-5; Nees, f. 105.

Iicea caesia, Schum. Saell., 1500 (1803).

Physarum difforme, Link, Diss., i., 27 (1809).

Amphisporium versicolor, Fr., Gast., 19 (1818).

Licea alba, Nees, in Kze., Myk., Heft., ii., 66 (1823).

Lycoyala minutum, Grev., S. C. Fl., t. 40 (1823).

Reticularia pusilla, Fr., Orb. Vet., i., 147 (1825).

Diderma cyanescens, Fr., S. M., iii., 109 (1829); Eng. Fl., v., p. 312 ; Cooke, Hdbk., No. 1115. 
Plysarum caesium, Fr., S. M., iii., 147 (1829).

Physamum album, Fr., S. M., iii., 147 (1829); Letell., t. 710, f. 4 ; Cooke, Hdbk., No. 1140.

Dilymium difforme, Duby, Bot. Gall., ii., 855 (1830).

Dilerma nitens, Klotzsch, in Hook. Herb.; Eng. Fl., v., p. 312 ; Cooke, Hdbk., 1113.

Diderma Ncesii, Corda, Ic., ii., f. 58 (1838).

Leocarmes cyanescens, Fr., S. V. S., 450 (1849).

Leocarpus nitens, Fr., S. V. S., 450 (1849).

Diderma Libertianum, Fres., Beit., t. iv., f. 16-27 (1850).

Didymium Libcrtianum, De Bary, Mycetozoa (1864).

\section{Chondrioderma Berkeleyanum, Rost. Trichamphora peis}

Sporangia slightly scutcllate, snow-white, stipitate; stem rigid, bay at the base, becoming palcr upvards; threads of capillitium slender, anastomosing to form a net; spores dingy violet, strongly warted, $10-11 \mu$ diameter.

Chonulvioderma Bicr\%clcyanum, Rost., Mon. App., p. 16 ; Sacc., Syll., no. 1258.

Island of Tahiti.

There is no specimen in the Berkeleyan Herbarium answering to the above description, and in the "Introduction to Cryptogamic Botany," p. 335, the spores are described and figured whth a reticulate epispore.

\section{(Rostafinski's Synonym.)}

Trichamphore pezizoides, Berk., Intr. Cr. Bot., p. 335, non Jungh.

Chondrioderma physarioides, Rost. (figs. 59-62). Liderma nive

Gregarious, sessile on a broad base, circular or irregularly elongated, lepressed, outer cretaceous wall polished, pure white or ivory tinted, inner wall dirty ochraccuss, sometimes separated from the outer wall by a space containing air; columella obsolete; threads of capillitium equal, about $3 \mu$ thick, colourless, sometimes rough in parts with minute particles of lime, branching 
irregularly and forming a flaceid net; spores globose, dingy violet, minutely verruceulose, 12-13 $\mu$ diameter.

Chondrioderma physarioides, Rost., Mon., p. 170; Cooke, Myx. Brit., p. 37.

Chondrioderma deplanatum, Rost., Mon. Append., p. 17; Sacc., Syll., 1264.

On rotten wood, leaves, \&c. Britain (King's Cliffe, Blackheath, Carlisle); France; Switzerland.

Sporangia 1-3 mm. when circular, from $3-5 \mathrm{~mm}$. when elongated; in the elongated form the sporangium is frequently folded on itself, and sometimes it takes two or three spiral turns, leaving a minute cavity in the centre. Distinguished from Chondrioderma difforme by the warted spores and large size of the sporangia, and from $C$. niveum by the absence of the columella, Sometimes the whole of the outer calcareous coat breaks away in a circumscissile manner close to the adnate base.

Chondrioderma crustaceum, Berl. Liderma glo bosum Pers.

Effused or circumambient, crowded, sessile, subglobose, smooth, white, outer peridium crustaceous, like the shell of some small egg, the inner delicate, appearing cinerous to the naked eye, iridescent under the microscope; columella none; spores globose, black, $\cdot 0005 \mathrm{in}$. in diameter ( = about $13 \mu$ ).

Chondrioderma crustaccum, Berlose, in Sacc., Syll., no. 1290.

Didcrma crustaceum, Peck, in 26th Report of State Mus., N. Y., p. 74.

On fallen sticks and leaves. Memplis; United States.

Owing to absence of information respecting the capillitium and presence or absence of markings on the epispore, the position of the species is uncertain.

\section{Chondrioderma liceoides, Rost. Didyowrianhifforme Loby}

Plasmodium seareely as thiel cus a needle, erceping or pulvinate, wall highly charged with lime, white externally, inside reddishbrown; inner wall contiguous to outer, delicate, violet ; capillitium filirly abundant, threads simple, or once or twice dichoto- 
mons near the apex, spores smooth, obscure violet, 11-12 $\mu$ diameter.

Chondrioderma liceoides, Rost., Mon. Append., p. 17 ; Sacc., Syll., 1262.

On rotten gourd. Carolina.

\section{(Rostafinski's Synonyms.)}

Licca macrosperma, Sz., Am. Fung., no. 2317 (1834).

Ligynota nigy'a, Fr., Sm. Veg. Scan., p. 459 in notarn. (1849).

\section{Chondrioderma reticulatum, Rost. Diderma effurum Hir}

Plasmodium sessile, vein-like, flattened, arcuate, combined into (tn irregular network, seated on a whitish, delicate, reticulated, spreading hypothallus; columella absent; threads of capillitium colourless, very thin, combined to form a dense net; spores smooth, obscure violet, $7-8 \mu$ diameter.

Chondrioderma reticulatum, Rost., Mon., p. 170.

On rotten branches of pine. Switzerland.

I have not seen the present species, but the description seems to suggest that it may possibly be a plasmodiocarp form of C'. Michelii.

\section{** Sporungium coloured.}

Chondrioderma ochraceum, Schroeter. Diderma och ruceur

Sporangia sessile, irregular, globose, reniform, semicireular, Sc., 1-2 mm. long, $1 \mathrm{~mm}$. across, densely gregarious, outer wall ochreccous-trowon, falling away in irregular squamules; inner wall thin, colourless; columella absent; capillitium copious, threads. $2-3 \mu$ thick, violet, smooth, straight or flexuous, frequently anastomosing, and here and there forming a dense reticulation; spores globose, indistinctly punctulate, blackishviolet, $9-11 \mu$ diameter.

Chondriodcrma ochraceum, Schroeter, Kr. Fl., 124; Sacc., Syll., v., 7, part, I., no. 1283 .

On hepatics. Silesia. 
Chondrioderma Sauteri, Rost. Diderma Souter Meely

Sporangia sessile, irregularly ellipsoid, depressed, blood-red, shining; inner wall whitish-brown, dull; columella absent, threads of the capillitium fasciculate but not forming a net; spores pale violet, verruculose, $8-12 \mu$ diameter.

Chondrioderma Sauteri, Rost., Mon., p. 181; Sacc., Syll., 1281. Tyrol.

There is some difficulty in ascertaining the exact meaning of the colour of the sporangium as given by Rostafinski, who calls it "kawowo-mleczne." It is translated in Saccardo's Sylloge as "sanguineo-lacteis."

\section{Chondrioderma vaccinum, Rost. liderma testacevm Ycrs}

Sessile, adnate, orbicular, outer wall thick, adnate, inner very thin, evanescent; columella absent; threads of capillitium hyaline, delicate; spores pale brownish-violet, $10-11 \mu$ diameter, minutely warted.

Chondrioderma vaccinum, Rost., Mon., p. 180; Sacc., Syll., no. 1275 .

Diderma vaccinum, Dur. et Mont., Fl. Alg., p. 407, t. 22 bis., f. 1 ; Mont., Syll., n. 1071.

(Type in Herb. Mus., Paris.)

On fallen branches of Opuntia. Algeria.

Externally bearing a close resemblance to Chondrioderma testaceum, but easily recognized by the absence of a columella; Chondrioderma sublateritium is separated from the present species in having the upper surface of the sporangium broadly umbilicate, and in the presence of a columella.

Chondrioderma simplex, Schroeter. Lidernia it mplex Lister

Sporangia sphaeroid, slightly flattened, scattered, simple, rigid, fragile, bright chestıut ; columella absent; tubes of capillitium radiating, repeatedly dichotomous, violet; spores smooth, bright violet, $7-9 \mu$ diameter.

Schroeter, Kr. Fl. Schles. Filze, p. 123; Sacc., Syll., 1272.

On dead trunks. Silesia. 


\section{Chondrioderma calcareum, Rost. Niderme difforme va}

Sporangia sessile and variable in form, ovate, elongated and curved, \&c., convexo-depressed, glaucous and hyaline when moist, opaque and reddish or pale when dry, very fragile, at length rupturing irregularly, leaving a brown impression of the base after falling away; spores $9-11 \mu$ diameter, mixed with a few black threads.

Chondriodcrma calcarcum, Rost., in Fckl. S. Myc., 2 Nch., p. 74 ; Rost., Mon., p. 179 ; Sacc., Syll., 1280 ; Schroeter, p. 124. On dry stems. Germany.

\section{(Rostafinski's Synonyms.)}

Lcocarpus calcareus, Link, Diss. I., l. c., p. 23 (1809).

Didcrma liccoides, Fr., l. c., iii., p. 107 (1829).

Diderma chalybeum, Wein., l. c., p. 592 (1836).

Diderma dcplanatum, Fckl., S. M., p. 341 ; Non. Fr. (1869).

Chondriodcrma calcareum, (Lk.) in Fckl., S. M., ii., Nch., p. 74 (1873).

Chondrioderma Stahlii, Rost. D.der m a rad i utum

Sporangia spherical, slightly flattened below, either dull whitish-brown or shining and dingy brown; dehiscing by a central pore, a long slit, or irregularly; stem brown, shining; columclla alsent; threads of capillitium either simple or more or less repeatedly bifurcate above, net combining to form a network; spores pale violet, minutely verruculose, $9 \mu$ diameter.

Chondrioderma Stahlii, Rost., Mon., p. 185, f. 168; Cooke, Brit. Myx., fig. 168; Sacc., Syll., 1287.

Germany.

\section{Didysium, Schrad. (in part).}

Sporangia stipitate or sessile, wall single or double, surface covered with lime, either in the form of a pulverulent stratum of amorphous particles or crystals, or compacted into a granular (but not porcelain-like) crust; columella present or absent; 
capillitium usually well-developed, threads thin, without lime, coloured or colourless, either radiating from the columella or base of sporangium as simple or furcate threads, which usually combine laterally towards the apex, or combine throughout their length to form a dense, irregular network, with the angles more or less triangular and flattened. Spores lilac or violetbrown.

Didymium, Schrad., Nov. pl. gen., p. 20. Rost., Mon., p. 160 (in part); Cooke, Myx. Brit., p. 30 (in part); Sacc., Syll., v., 7, pt. I., p. 376 (in part); Zopf, :p. 150.

The leading idea of the genus as defined above is, the wall of the sporangium with lime outside, the thin threads of the capillitium not containing lime, either radiating, subsimple or bifurcating, or anastomosing irregularly throughout their length and forming a net as in the subgenus Hemididymizm, the species of which are distinguished from those of Tilmadoche by the absence of well-defined, small, usually fusiform knots containing granules of lime. Thickenings are not uncommon in the capillitium of various species of Didymizom, but lime is never present.

Distrib. Temperate and tropical regions. Species ə̌0.

\section{Sub-Gen, Didymium.}

Threads of capillitium alnost simple, or bifurcating at acute angles, here and there connected laterally, but not forming a uniform net throughout the capillitium.

\section{A. Sporangium stipitate.}

(Sessile forms occur in D. squamulosum and D. farinaceum.)

\section{* Spores warted.}

Didymium farinaceum, Schrad. (figs. 29-35). D melanospermum flacb:

Sporangium hemispherical, usually a little depressed, more or less umbilicate below, at first white with a continuous crust of lime, which soon becomes broken up into white glistening granules scattered on the inner dark, wrinkled wall; stem 
variable in length, blackish or mfous, wrinkled longitudinally, equal or slightly attenuated upwards, expanding at the base into a rudimentary hypothallus; columella hemispherical or depressed, corered with the inner dark brown wrinkled skin; lacunose, the cavities filled with amorphous masses of lime; capillitium copious, threads springing from the columella, $2-3 \mu$ thick, almost equal, dividing in a dichotomous manner, and becoming attached to the inner wall of the sporangium, the branches often connected laterally, and often more or less studded with very minute granules of lime, varying from colourless, through pale brown to dingy violet; spores globose, dirty brownish-purple, minutely warted, 10-13 $\mu$ diameter.

a. genuinum. Stem blackish or brown, as long or longer than the height of the sporangium.

$\beta$. subsessile. Stem short, almost or altogether concealed in the umbilicus of the sporangium. Sporangia solitary or more or less confluent.

$\gamma$. nigrum. An abnormal form without lime, hence the sporangium from the first blackish. Stem short.

Didymium farinaceum, Rost., Mon., p. 154, figs. 128, 171, 174; Cooke, Myx. Brit., p. 31, figs. 128, 171, 174; Sacc., Syll., 1039 ; Schroeter, p. 121 ; Raunk., Myx. Dan., p. 89.

Dillymium lobatum, Fr. (specimen named by Fries, in Herb. Berk., n. 10753).

Exsicc.-Jack, Leiner u. Sitzenb., 424; Cooke, Fung. Brit., Ed. II., 521 ; Fuckel, Fung. Rhen., 1461; Klotzsch., (Rab.) Herb. Myc., 138; Rab., Fung. Eur., 369.

On wood, bark, leaves, living moss, \&c.

Britain (Chislehurst, Kew, Carlisle, Scarboro', Durham, Linlithgow, Appin); Sweden; Germany ; Bavaria; France; United States; S. W. Australia; Bonin Islands.

Sporangia 5-1 $\mathrm{mm}$. across, sometimes lobed, a character which gave origin to the spurious species $D$. lobatum; sometimes two or several sporangia coalesce, the stems remaining distinct. The stem varies considerably in length, even in the same group, thus showing the small amount of value to be attached to Rostafinski's forms; in some specimens the stem 
is three times as long as the height of the sporangium, in others so short as not to project beyond the umbilicus or depression at the base of the sporangium. The threads of the capillitium are often flexuous. The columella is at first dusky owing to being covered with the dark inner skin of the sporangium, but in old plants this pellicle frequently disappears, leaving a white mass of lime, hence the columella appears white.

\section{(Rostafinski's Synonyms.)}

Sphaerocephalus niger, Hall, t. 1, f. 2 (1742).

Trichia, Hall, No. 2160, t. 48, f. 2 (1768).

Mucor sphaerocephalus, Batsch., p. 157 (1783).

Clathrus sphaerocephalus, Rehl.(1786).

Trichia globosa, Vill., Fl. Dauph., 1061 (1789).

Reticularia hemispherica, Bull., t. 446, f. 1 (1791).

Trichia compressa, Trent, p. 229 (1797).

Trichic sphaerica, Trent, p. 230 (1797).

Trichia depressa, Trent, p. 231 (1797).

Physarum melanospermum, Pers. Disp., p. 8 (1797).

Didymium farinaceum, Schrad., t. 3, f. 6 (1797); Engl. Flor., v., 313; Cooke, Hdbk., No. 1123; Fung. Brit., Ed. II., 521. Trichia sphaerocephala, Sow., t. 240 (1799).

Trichia farinacea, Poir., Encycl., viii., 53.

Physarum farinaceum, Pers. Syn., 174 (1801).

Physarum cinerascens, Schum. Saell., 1426 (1803).

Physarum depressum, Schum. Saell., 1439 (1803).

Physarum globosum, Schum. Saell., 1442 (1803).

Physarum oxyacanthae, Schum. Saell., 1427 (1803).

Physarum cinereum, multis?

Physarum clavus, Link, Diss., i., 27 (1809).

Physarum sinuosum, Link, Diss., i., 27 (1809).

Physarím capitatum, Link, Diss., i., 27 (1809).

Diderma muscicola, Link, Diss., i., 27 (1809).

Didymium capitatum, Link, Diss., iii., 27 (1816).

Didymium lobatum, Nees, f. 104 (1817); Cooke, Hdbk., No. 1129. 
Didymium physarioides, Klotzsch.

Strongylium minor, Fr., Gast., p. 9 (1817).

Physarum melanopus, Fr., Gast., p. 23 (1817).

Conium lobatum, Spr., Syst., iv., 529 (1827).

Didymium marginatum, Fr., S. M., iii., 116 (1829).

Didymium melanopus, Fr., S. M., iii., 114 (1829); Berk., Ann.

N. H., No. 382 ; Cooke, Hdbk., No. 1118.

Didyminem hemisphericum, Fr., S. M., iii., 115 (1829).

Physamum nigrum, Fr., S. M., iii., 146 (1829); B. and Br.,

N. H., No. 1598; Grevillea, v., p. 12.

Cionium farinaceum, Link, Hdbk., iii., $416^{\circ}$ (1833).

Didymium filamentosum, Wallr., 2187 (1833).

Didymium affine, Raunk. D.savamulosum ir

Sporangia spherical-hemispherical, stipitate. Stem thin, of equal length or longer than the sporangium, expanded into a circular hypothallus at the base, bright brown. Wall grey, without lime, under the microscope colourless. Columella globose-semiglobose, with the colour of the stem or brighter. Threads of the capillitium nearly hyaline, expanded into numerous shortly fusiform, bronnish-violct swcllings. Spures smooth or delicately warted, $8-9 \mu$ diameter.

Didymium affine, Raunk., Мyx. Dan., p. 109 (in English), Tab. 5, figs. 3, 4.

On germinating seeds in laboratory.

Copenhagen.

An unusual Didymizm certainly in the wall being without lime. Possibly abnormal.

Didymium Fuckelianum. Rost. D. Squamulosum in

Sporangia hemispherical, umbilicate below, stipitate, stem whitish with gilvous or brownish shades, strongly plicate longitudinally, lime on the wall in the form of stellate crystals, after removal of the lime the wall is covered with unsymmetrical brown. or violet spots separated by colourless veins; stem entering the sporangium as a distiuct clevate or applanate brounish columella, 
not at all adherent to lower part of the sporangial wall, surface covered with protuberances which give origin to the threads of the capillitium, threads violet, with numerous irregular protuberances; spores lilac, delicatcly warted, 9-11 $\mu$ diameter.

Didymium Fuckelianum, Rost., Mon., p. 161, f. 134; Cooke, Myx. Brit., f. 134; Sacc., Syll., No. 1307.

On twigs and pine leaves. Germany.

-(Rostafinski's Synonyms.)

Didymium squamulosum, Fckl., Symb. Myc., p. 341, non A. et. Sz. (1569).

Didymium Fruckelianum, Rost., Fckl., S. N., 2, Nach., p. 73 (1873).

Didymium praecox, De Bary. L.squamulosum Fr

Sporangia irregularly hemispherical, wall double, the outer white, strongly rugulose, after maturity breaking away in small colourless patches, covered with minute stellate crystals; inner wall greyish lead-colour, rigid, with small irregular granules of lime, yellowish flesh-colour after removal of the lime; stem generally short, yellowish flesh-colour, with delicate oblong striations, passing into the peridium as an irregularly spicerical, often applanate yellowish flesh-coloured prolongation; threads of capillitium very delicate, solid, colourless, or some violet with many irregularly spherical protuberances below the acute angles of the bifurcations, combined constantly by the branches and transverse threads to form a network; spores subviolet, membrane very rigid, with a few scattered short spines, 8-9 $\mu$ diameter.

Didymium praccox, De Bary, in Rab., Fung. Eur., n. 367; Rost., Mon., p. 163; Sacc., Syll., 1306.

Germany.

Didymium squamulosum, Fr. (figs. 46-52).

Sporangia subglobose, slightly flattened below, and more or less umbilicate, stipitate or sessile, coat of lime at first consisting of a continuous white crust of minute granules, which soon 
becomes broken up into large, irregular, persistent patelucs; mass of spores brownish-black; stem white, equal in length to sForangium or much shorter, slightly rugulose; columella vhite or dirty ochraccous, large, subglobose; threads of capillitium pale or colourless, about equal throughout their length, $2-3 \mu$ thick, branching at acute angles and connected laterally, forming a net, sometimes flexuous; spores globose, dingy violet, minutely verrucose, 8-11 $\mu$ diameter.

Didyminu hypnophilum, Mass., Journ. R. Micr. Soc., v., 5. p. 757.

Didymium neglcetum, Berk., Linn. Soc. Journ., v., 14, p. 83; Sacc., 1325.

a. genuinum. Sporangia stipitate, stem elongated or short, and almost lost in the umbilicus of the sporangium.

B. sessilis. Sporangia sessile, distinct, or sometimes several confluent, when the columella becomes elongated.

Dilymium squamulosum, var. genuinum, Rost., Mon., p. 159, f. 148; Cooke, Myx. Brit., p. 33, f. 148; Schroeter, p. 122 ; Raunk., p. 88; Sacc., Syll., 1301.

Exsice.-Syd., Myc. March., 1387, 1388; Cke., Fung. Brit., Ed. II., 613; Rab., Fung. Eur., 813; Rab.-Wint., Fung. Eur., 2969 ; Roum., Fung. Gall., 1212; Fuckel, Fung. Rhen., 2497 ; Syd., Myc. March., 396 (as Didymium farinaceum); and 492 (as Didymium herbarum, Fr.); Ellis, N. Amer. Fung., 1216; Roum., Fung. Gall., 168t (as Didymium farinaccum); Klotzsch (Rab.), Herb. Myc., $\$ 55$ (as Didymium hemisphericum).

On rotten wood, leaves, moss, \&c.

About $1 \mathrm{~mm}$. high, distinguished by the calcareous crust of the sporangium becoming broken up into large irregular patches, separated from each other by the blackish inner layer and the pale columella. Most closely allied to Didyminu virginenm. For distinctive characters see under the latter.

Britain (Kew, Wothorpe, King's Cliffe, Norwich, Scarboro', Carlisle, Glamis, Appin, N. B.); France; Italy; Germany ; Switzerland; Belgium; U. States; Cuba; Ceylon; Australia; Tasmania; New Zealand. 
Var. costatum, Mass.

Sporangia covered uniformly with minute particles of lime, not becoming broken up into large, distinct patches; stem white, variable in length, expanding at the base into a small hypothallus with prominent radiating ridges. Stem sometimes very short, sunk in the umbilicus or entirely absent.

Didymium squamulosum, $\beta$. leucopus, $\gamma$. costatum, Rost., Mon., p. 159 ; Cooke, Myx. Brit., p. 33; Sacc., Syll., no. 1301.

Exsicc.-Rab., Fung. Eur., 367 (as Didymium praecox, De Bary); Fuckel, Fung. Rhen., 2690 (as Didymizum: squamulosum

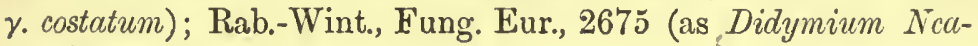
politanum, Ces.).

On leaves, wood, \&c.

Distinguished from the type by the white crust of the pileus not becoming broken up into patches, and by the markedly costate hypothallus. Somewhat resembling Didymium depressum, Fr., which however is readily distinguished by the much larger and more coarsely warted spores.

Britain (Epping Forest, Chiselhurst, Kew, Carlisle); France; Germany; Austria.

\section{(Rostafinski's Synonyms.)}

Reticularia hemispherica, Bull., p. 93 (1791).

Diderma squamulosim, A. and S., t. 4, f. 5 (1805).

Didymium globosum, v. stipitatum, Schwarz., Ac. Holm., p. 114 (1815).

Licea stipitata, D. C., Fl. Fr.; No. 670 (1815).

Tubulina pedicellata, Poir., Ency., v., p. 373.

Cionium farinaceum, Spr., Syst., iv., 528 (1827).

Didymium herbarum, Fr., S. M., iii., 120 (1829).

Didymium leucopus, Fr., S. M., iii., 121 (1829); Cooke, Hdbk., No. 1127.

Didymium costatum, Fr., S. M., iii., 118 (1829).

Didymium liceoides, Duby, Bot. Gall., ii., 864 (1830).

Didymium filamentosum, Wallr., Fl. Germ., No. 2187 (1833). 
Didymium squamulosum, Fr., S. M., iii., 118; Eng. Fl., v., 312; Cke., Hdbk., No. 1122.

Didymium neglectum, B. and Br., Ceylon Fungi, No. 747.

Didymizm australe, Berk., Hdbk., Flor. Nov. Zealand, p. 191.

Var. virgineum, Mass.

Seattered, or in clusters of two or three; sporangia subglobose, flattened and slightly umbilicate below, external crust of lime pure white, rugulose and crumpled but continuons; stem white, stout, equal to sporangium or shorter, expanding at the base into a small wrinkled hypothallus; mass of capillitium and spores blackish; eolumella subglobose or hemispherical, white or yellowish, rugulose; threads of capillitium copious, radiating from the columella to the wall of the sporangium, $3-4 \mu$ thick at the base, a little thinner upwards, often flexuous, sparingly branching at an acute angle, and sometimes connected laterally, with scattered, small, elliptical swellings, pale dingy violet or brownish, sometimes almost colourless; spores globose, epispore rather thick, brownish-violet, minutely verruculose, 10-13 $\mu$ diameter.

On leaves, wood, \&c.

Britain (Scarborough, Carlisle, Epping Furest); Italy.

(Type in Herb., Kew.)

Sporangia 1-1.5 mm. diameter. The outer coat of lime is very much crumpled, with prominent irregular ridges, but does not become broken up into detached particles as is usual in the genus Didymium.

Didymium microcarpon, Rost. (figs. 44, 45). D.nigripes Fr.

Sporangia globose, at first with an external continuous white crust of lime, which soon becomes broken up into minute glistening particles, resting on the inner dark membrane, more or less umbilicate below, stem slender, slightly attenuated upwards, blackish or rufous, longitudinally rugulose, expanding at the base into a small subcircular hypothallus, straight or slightly curved above, generally about twice the length of the sporangium; 
columella small, spherical, pale ochraceous, internally traversed by irregular strands giving it a cellular appearance, cavities containing crystals of lime; capillitium radiating from the columella to the wall of the sporangium, threads about equal, $2-3 \mu$ thick, repeatedly forked and joining laterally, sometimes flexuous and rough in parts with minute granules of lime, varying from colourless, through pale brown to dirty violet; spores globose, very minutely verruculose, brownish-purple, $5-7 \mu$ diameter.

a. nigripès. Stem blackish.

$\beta$. rufipes. Stem rufous or yellowish.

Didymium microcarpon, Rost., Mon., p. 157, f. 133, 177 ; Cooke, Myx. Brit., p. 32, f. 133, 177 ; Sacc., Syll., 1316; Ra!nk., p. 87.

Exsicc.-Ellis, N. Amer. Fung, 1393 (as Didymium microcarpon, Fr.), var. nigripes; Ellis, N. Amer. Fung., 412 (as Didymium xanthopus).

On twigs, leaves, living mosses, \&c.

Plants $25-3 \mathrm{~mm}$. high, lumps of lime on the sporangium in the form of stellate crystals; umbilicus at base of sporangium sometimes very slight; columella small but rather prominent; the capillitium varies considerably, sometimes copious, anastomosing, various, inclined to be rough here and there with minute granules of lime, or even nodulose; at other times scanty, colourless, and threads very thin. So far as I have had an opportunity of ascertaining, the pale-stemmed form is confined to living mosses.

Britain (Kew, King's Cliffe, Carlisle, Shere, Forden, Edinboro', Glamis, N. B.); Sweden; Denmark; France; United States; Ceylon.

(Rostafinski's Synonyms.)

Lycoperdon stipitatum, Retz., Vet. de Handl. (1769).

Trichia hemispherica, Trent., p. 228 (1797).

Physarum nigripes, Lk., Diss., 1, 27 (1809); Ditm., t. 42.

Trichia alba, Purt., Midl. Fl., iii., 1113 (1817).

Cionium xanthopus, Ditm., t. 43 (1817); Nees, f. 106.

Physarum microcarpon, Fr., Gast.; p. 23 (1818). 
Didymium lobatum, $\beta$. stipitatum, Somm., Fl. Lapp., 210 (1825).

Didymium nigripes, Fr., S. M., iii., 119 (1829); Eng. Fl., v., 313; Cooke, Hdbk., No. 1124.

Didymium xanthopus, Fr., S. M., iii., 120 (1829); Berk., Ann.

N. H., iii. ; Cooke, Hdbk., No. 1126.

Didymium iridis, Fr., S. M., iii., 120 (1829).

Dülymium microccphalum, Chev., Byss., f. 11 (1837).

Didymium melanopus, Wallr., Fl. Germ., 2184 (1837).

Dülymium Wallrothii, Rabh., Fl. Cr., 2289 (1844).

Didymium porphyromus, D. R. and M., Fl. Alg., 409 (1846).

Didymium megalospomum, B. and C., Grev., No. 318.

Didymium macrospermum, Rost. L. squa mulosum. Fr.

Sporangia spherical or hemispherical, very much flattened vertically, umbilicate below, grey, stipitate, membrane of sporangium colourless or pale brownish; stem generally longer than peridium, dilated at the base into a distinct discoid hypothallus, attenuated above, strongly plicate longitudinally, snow-ichite or yellowish-white; columelle versiform, discoid, \&c., threuls of capillitium simple, rarely branching. at acute angles, colourless or pale brown; spores subviolaceous, strongly aculcate, $12-13 \mu$ diameter.

Dudymium macrospermum, Rost., Mon., p. 166; Schroeter, p. 122 ; Sacc., Syll., n. 1304.

On trunks. Germany.

Gregarious; stem three or more times longer than the sporangium, thinner above, much wrinkled, ridges membranaceous, pellucid, peridium thin, sometimes dehiscing by becoming ruptured at the base, and almost, all disappearing; at other times torn into shreds which persist. Appenrs to be allied to Didymium squamulosum, var. costatum, and distinguished by the flattened sporangium, long stem, and larger' spores.

(Rostafinski's Synonyms.)

(?) Trichia alata, Trent., l. c., p. 228 (1797). 
(?) Physarum alatum, Fr., l. c., iii., p. 132 (1829).

Didymium costatum, Fckl., Sym. Myc. I., Nach., p. 339.

Didymium discoideum, Rost. D.squamulosum $\mathrm{Fr}$.

Sporangia discoid, almost sessile, umbilicate, inferior part of wall violet, superior spotted, with irregular pellucid veins, breaking away after maturity in small patches; stem from its shortness scarcely apparent, hid in the umbilicus, dilated at the base into a circular hypothallus; columella discoid or hemispherical, like the stem yellowish flesh-colour; threads of capillitium flexuous, rarely forking, bay, tips colourless; spores strongly warted, blackish-violet, $11-13 \mu$ diameter.

Didymium discoideum, Rost., Mon., p. 162; Sacc., Syll., no. 1305.

Germany.

\section{* * Spores smooth.}

Didymium radiatum, B. and C. (figs. 68-72). A. squamulosum Fr.

Scattered, sporangia vertically compressed, not umbilicate, but sometimes slightly depressed below, dark grey, with crowded, small, white, innate patches of lime, dehiscing irregularly; stem longer than beight of sporangium, slightly attenuated upwards, white or pale grey, expanding into a small, circular hypothallus, longitudinally costate, the ribs pussing in a radiate manner into the hypothallus; columella brownish, much compressed; capillitium abundant, radiating from the columella to the wall of the sporangium, threads thin, brownish-lilac, sometimes forked; spores globose, lilac, smooth, 8-10 $\mu$ diameter.

Didymium radiatum, B. and C., Journ. Linn, Soc., vol. x., p. 348; Sacc., Syll., n. 1328.

(Type in Herb. Berk., Kew, no. 10765.)

Didymium commutabile, B. and Br., Journ. Linn. Soc., v. xiv., p. 83 ; Sacc., Syll., n. 1300; Rost., App., p. 21.

(Type in Herb. Berk., n. 10766.) 。

Didymium botryoides, Berk. in Herb.

f. gcnuinum. Simple, scattered; stem usually longer than sporangium. 
f. fasciculatum. Three to five sporangia confluent, supported on a common stem.

On wood, leaves, moss, \&c. Cuba; N. Zealand; Ceylon.

Remarkable for the circular, sharply limited hypothallus with prominent, regularly radiating ribs, resembling the hymenium of a small agaric. Resembling superficially some forms of Dilyminu squamulosum, var. costatum.

\section{Didymium clavus, Rost. (figs. 53, 54).}

Sporangic very much depressed, slightly convex above, plane below, lime sprinkled in fine crystals on the surface of the dark membrane; stcm short, blackish-brown, more or less longitudinally rugulose; columella absent; mass of spores blackish; threads of capillitium 3-4 $\mu$ thick at base, slightly tapering, sparingly forked at acute angles, and sometimes laterally connected and furnished with small ring-like dark-coloured thickenings, pale brown to dirty violet; spores globose, smooth, dingy lilac, $6-8 \mu$ diameter.

Dr̈̈ymium clavss, Rost., Mon., p. 153; Cooke, Hdbk., p. 30; Raunk., p. 87; Schroeter, p. 121 ; Sacc., Syll., 1299.

On twigs, leaves, \&c. Britain (Weybridge, Kew, Orton Wood, Leicester; Epping Forest, Forden, Linlithgow); France; Belgium; Germany; United States; Canada ; Egypt; Ceylon.

Sporangia scattered, $1-15 \mathrm{~mm}$. across when circular, sometimes irregular and larger. Remarkable for the nuch flattened, pileus-shaped sporangia.

\section{(Rostafinski's Synonyms.)}

Reticuluriu hemispherica, Bull., t. 446, f. 2 (1791).

Physarnem clavus, A. and S., t. 2, f. 2 (1805).

Didymium mclanopnes, $\beta$. claves, Fr., S. M., iii., 114 (1829);

B. and Br., Ann. N. H., No. 110 ; Cooke, Hdbk., No. 1118, $\beta$.

Didymium hemisphcricum, Wallr., Fl. Germ., 2192 (1833).

Dillyminu clavns, Rabb., Fl. Crypt., 2282 (1844).

Diulymium clavus, Berk., Eng. Fl., v., p. 314. 
Didymium neglectum, Mass. (nov. sp.); (fig. 207). \&. clavus Rost.

Sporangia globose or slightly depressed, flattened or sometimes slightly umbilicate below, stipitate; wall single, at first with a continuous, rugose, white crust of lime, which at maturity becomes broken up into minute, persistent particles; stem equal to or longer than height of sporangium, erect, slightly attenuated upwards, black, longitudinally wrinkled, expanding at the base into a small hypotha!lus; columella circular in outline, much depressed, placentiform, with a distinct margin, covering the base of the sporangium, rugulose, pale brownishlilac, capillitium dense, threads radiating from the columella, lilac-brown, becoming colourless towards the tips, bifurcating, now and then anasmosing laterally; spores globose, smooth, 7-9 $\mu$ diameter.

On wood. Fairmount Park, Philadelphia, U. S.

Solitary or in scattered clusters of $2-6$ specimens, about $1 \mathrm{~mm}$. high; superficially resembling Didymium farinaceum, but quite distinct in the smooth spores, which only show vague indications of roughness when magnified 1200 diameters. The columella is very characteristic, being broad and flattened with a distinct margin; at maturity the sporangium falls away except a minute frill round the lower edge of the columella, which, with the stem, in this condition resembles a little table. The original specimens were found mixed with specimens of Tilmadoche oblonga, communicated by Mr. Harold Wingate, of Philadelphia.

Didymium Barteri, Mass. (n. sp.). Physarum compactum Lister

Gregarious; sporangia spherico-depressed, slightly umbilicate below, stipitate, cretaceous layer pure uhite, rugulose, for a long time persistent, then breaking away in small granules; stem elongated, slender, attenuated upwards, pure white, strongly wrinkled longitudinally; columella small, globose, white; mass of spores blackish-purple; capillitium copious, threads about $2 \mu$ thick, equal, sometimes flexuous, forked at an acute angle 
and combined laterally to form a flaccid, irregular net; spores globose, smooth, pale dingy lilac, $10-11 \mu$ diameter.

(Type in Herb., Kew.)

On moss. W. Africa (Niger Expedition, Barter).

A very beautiful and distinct species, known at once by the snow-white sporangium, stem, and columella, and the smooth spores. Plant $3 \mathrm{~mm}$. high; stem $2.5 \mathrm{~mm}$. high, sporangium $.5 \mathrm{~mm}$. high, a little more in diameter.

B. Sporangium sessile.

(In D. smmarioides and D. physarioides, a very short stem is sometimes present.)

Didymium Alexandrowiczii, De Bary and Rost. D.squamulosvm?

Sporangia sessile, deformed, not truncate, several often collected in little elusters, rugulose, granulose; columella absent; threads brownish, colourless at both ends, simple or bifurcating and laterally connected; spores smooth, obscure violet, $10-12 \mu$ diameter.

Didymium Chondroderma, De Bary and Rost., in Alex. Stroz., p. 89.

Chondrioderna Alcxandronviczii, Rost., Mon., p. 169, f. 176 ; Sacc., Syll., 1253; Cooke, Myx. Brit., f. 176.

On wood Britain (Kew); Poland.

Didymium spumarioides, Fr. Lidern a spumariodestr.

Sporangia substipitate or sessile, scattered or densely crowded on a well-developed, white or pale flesh-coloured hypothallus contuining much lime; wall of sporangium white or grey, erust of lime pulverulent; columella variable, smooth or irregularly rugulose, white or pale flesh-colour, sometimes almost obsolete; threads of capillitium about equal, $15-2 \mu$. thick, repeatedly bifurcating and connected laterally to form a net, colourless or dingy lilac, spores globose, minutcly warted, $9-12 \mu$ diameter.

Didyminu spumarioules, Fr., Symb. Gast., 20.

Chondriodermu spumarioides, Rost., Mon., p. 173, f. 142-145, 
151 ; Cooke, Myx., p. 38, f. 142-145, 151; Schroeter, p. 123 ; Sacc., Syll., n. 1269.

Chondrioderma stromateum, Rost., Mon. Append., p. 18, f. 151. Diderma farinaceum, Peck, 26th Report State Mus., N. Y., p. 74 .

Exsicc.-Fckl., F. Rhen., 2495 (as Carcerina spumarioides, Fr.); Rab., F. Eur., 432 (as Carcerina spumarioides, Fr.); Cke., F: Brit., Ed. II., 825 ; Roum., Fung. Gall., 1682.

On living or dead leaves, moss, \&c.

Britain (Highgate, Shere, Scarboro'); France; Germany; Sweden; Belgium; Italy; United States; Australia.

The present species was placed by Rostafinski in the genus Chondrioderma, from which it differs, according to our interpretation of the genus, in the pulverulent, instead of porcelainlike coat of lime. Very variable in colour and size of the columella, but well marked by the highly-developed hypothallus, which sometimes becomes so thick as to suggest the idea of a stroma. Sporangia from $5-1.5 \mathrm{~mm}$. diam., circular or irregularly angular from mutual pressure, sometimes the stroma, when very thick, forms a short stem-like projection; the colour of the stroma and columella varies from chalk-white through pale tints to pale flesh-colour.

(Rostafinski's Synonyms.)

Spumaria physarioides, Pers. Syn., 163 (1801).

Physarum didermoides, Fries, Herb.

Spumaria alba, Schum. Saell., No. 1414 (1803); Fl. Dan., t. 1798, f. 2.

Didymium spumarioides, Fr., Symb. Gast., 20 (1818).

Physarum stromatium, Link, Hdbk., iii., 409 (1833).

Carcorina spumarioides, Fr., S. V. S., 451 (1849).

Diderma spumarioides, Fr., S. M., iii., p. 104; Eng. Fl., vol. v., p. 311 ; Cke., Hdbk., No. 1109.

Didymium physarioides, Rost. Didymium melanospermunto

Sporangia cylindric-oblong, often crowded and deformed, seated on a well-developed hypothallus, sessile or with a short 
stem, wall dark grey, at first with granules of lime; columella irregular, more or less confluent and common to all the sporangia; threarls of capillitium $2-3 \mu$ thick at base, with but few bifurcations, with numerous fusiform or discoid dingy purple thickenings, spores globose, brownish purple, warted, 12-14 $\mu$ diameter.

Didymium physarioides, Rost., Mon., p. 158, fig. 147; Cooke, Myx. Brit., p. 33, f. 147 ; Sacc., Syll., no. 1311.

On moss and wood. Britain (King's Cliffe, Carlisle); Germany; Sweden; United States; Cape of Good Hope.

Often superficially resembling Physumum didermoides.

Didyminm serpula, Fr. (figs. 55-57) deo planatym Rust

Sporangia sessile on a broad base, much adpresscd, circular in outline, or variously elongated and flexuous, and sometimes the branches combine to form an irregular network, wall dark grey, sparingly sprinkled with minute white particles of lime; columella absent; mass of spores blackish ; threads of capillitium branched and connected laterally, forming an irregular network, dirty brown to colourless, plentifully furnished with dark-coloured, ring-like, or irregularly-shaped thickenings; spores globose, very minutely vervuculose, 7-9 $\mu$ diameter.

Dirlymium serpula, Rost., Mon. Append.; Cooke, Hdbk., 30, figs. 166, 180 ; Schroeter, p. 121 ; Sacc., Syll., no. 1297.

Dilymium complanatum, Rost., Mon., p. 151, figs. 166, 180.

On leaves, \&c. Sporangia when circular $5-1$ mm. diameter ; when elongated often several $\mathrm{mm}$. in length. Sometimes the lime on the sporangium is more abundant, forming a white crust; but the species cannot be mistaken if attention is paid to the much flattened sporangia, the well-developed capitulum having the threads furnished with numerous, variously-shaped, dark brown thickenings, and the very minutely verruculose spores.

Britain (Kew, Batheaston, Scarboro', Carlisle); all Europe; United States. 


\section{(Rostafinski's Synonyms.)}

Lycoperdon complanatum, Batsch, t. 170 (1786).

Didymium serpula, Fr., S. M., iii., 126 (1829); Eng. FI., v., 314; B. and Br., Ann. N. H., No. 1035; Cke., Hdbk., n. 1134 .

Physarum confluens, Fckl., Symb. Myc., p. 342 (1869), non Pers.

Didymium cenfluens, Rost. A. squamulosum Rost

Sporangia sessile, sometimes scattered and then hemispherical, at others densely crowded on a well-developed hypothallus, hemispherical reniform, or irregularly angular from mutual pressure; columella distinct, yellowish, or with a pink tinge; threads of capillitium very slender, forked at acute angles, pale brownish-lilac;; spores globose, rather coarscly warted, dingy purple-brown, $10-15 \mu$ diameter.

Didymium confluens, Rost., Mon., p. 164.

Didymium crustaceum, Sacc., Syll., no. 1303.

On leaves, wood, \&c. Britain (Castle Howard, Yorks); France; Italy; Russia; Finland.

\section{(Rostafinski's Synonyms.)}

Didymium complanatum, Schrad., Nov. Plen. Gen., p. 24, t. 5, f. 5 (1797).

Physarum confluens, Pers. Syn., p. 169, et v., a truncigerum (1801).

Physarum confuens, $\beta$ muscigcnim, A. et Sz., l. c., p. 9 (1805). Didymium crustaccum, F., 1. c., iii., p. 124; Excl. Syn. (1829).

Cionium complanatum, Lk. ap. Wallr., 1. c., no. 2176 (1833).

Var. obducens, Karst., Not. Sallsk., pro. faun. et flor. Fenn., ix., p. 356 (1880).

Sporangia irregular (plasmodiocarp), flattened, often umbilicate, concave below, solitary or gregarious, sometimes densely crowded; stem short or almost obsolete, irregular, broadening out below into the common hypothallus. Remainder as in type. 
Didymium effusum, Rost. D. squamulosum Fr

Sporangia densely aggregated or scattered, sessile on a broad base, circular or irregular ir outline, depressed, wall grey, pruinose with numerous minute crystals aggregated in masses; columella hemispherical, white or pallid, rugulose; threads of capillitium very slender, colourless or pale fuliginous, furnished with scattered coloured protuberances, combined to form an irregular dense net; spores globose, brownish-purple, minutely warted, 10-12 $\mu$ diameter.

Didymium effusum, Rost., Mon., p. 163; Sacc., Syll., no. 1302.

On leaves, wood, \&c. Britain (Cornwall); Finland; Sweden; France; Germany; United States; Ceylon.

About $5 \mathrm{~mm}$. diameter, characterized by the white columella, the capillitium threads furnished with numerons well-defined projections in the form of thickened plates or pyriform swellings, and the dense meal of crystals on the wall.

\section{(Rostafinski's Synonyms.)}

Diterma effusum, Link, Obs. I., p. 42 (1809).

Didymium effisum, Fr., 1. c., iii., p. 124 (1829).

Physarum confluens, Fr., Excl. Syn., l. c., iii., p. 146 (1829).

\section{Sub-Gen. Hemididymium.}

Capillitium usually dense, threads branching and anastomosing to form an irregular network throughout the capillitium, angles usually flattened and more or less triangular.

The species included in the present sub-genus are distinguished from those belonging to the sub-genus Didymizm by the absence of the simple or bifurcating threads at the basal portion of the capillitium.

\section{A. Sporangium stipitate.}

* Spores smooth.

Didymium longipes, Mass. (n. sp.) (fig. 226). Phy sa runi qlo bul

Sporangria small, globose, snowv-white, frosted with a few scattered granules or crystals of lime; stem very long and 
slender, erect, snow-white, very slightly attenuated upwards, almost smooth, expanding at the base, into a small, circular, white hypothallus; columella absent; capillitium well-developed, threads very thin, colourless, branching and anastomosing irregularly to form, a network, nodes usually triangular; spores globose, dingy lilac, smooth, $8-10 \mu$ diameter.

(Type in Herb. Berk., Kew,.with Tilmadoche nutans.)

On bark and wood. Britain (Yorks); Lower Carolina.

A very distinct species, characterized by its snow-white colour throughout, $25-3 \mathrm{~mm}$, high, sporangium very small. Spores perfectly smooth under a $\frac{1}{12}$ objective.

Didymium fulvellum, Mass. (n. sp.) (fig. 232). D. nigripes var eyimium

Sporangia spherical, very little or not at all umbilicate, stipitate, outer cretaceous coat pure white, composed of minute granules which fall away in the form of powder, inner wall without lime, rather tough, bright fulvous; stem slender, elongated, straight or slightly curved above, attenuated upwards, same colour as inner wall of sporangium, much wrinkled longitudinally, expanding at the base into a similarly colourcd circular hypothallus; columella brovin, not very prominent; mass of spores blackish with a purple tinge; capillitium copious, threads repeatedly forked, $2-3 \mu$ thick, rather broader at the base of each bifurcation, combined laterally to form an irregular network, colourless; spores globose, smooth, pale dirty lilac, 8-10 $\mu$ diameter.

On fallen oak leaves; scattered or gregarious.

United States.

(Type in Herb., Kew.)

Sporangium $1 \mathrm{~mm}$. diameter, stem about $2 \mathrm{~mm}$. high.

Didymium australis, Mass. (fig. 208). Trichamplova pezizoidea

Sporangium globose or slightly flattened above and below, slightly umbilicate, at first with a thick, white layer of crystals which soon breaks up into large, persistent, irregular patches; stem thin, bright brown, slightly attenuated upwards, often bend- 
ing under the weight of the sporangium; columclla absent; mass of spores blackish-purple; capillitium copious, threads colourless, $3-4 \mu$ thick, branching at wide angles and anastomosing irregularly; spores globose, smooth, dingy lilac, $9-10 \mu$ diameter.

Didymium australis, Mass., Grev., vol. xvii., p. 7.

(Type in Herb., Kew.)

Gregarious, on an old decayed species of Auricularia.

Brisbane, Australia.

Plant about $2 \mathrm{~mm}$. high, stem equal or a little longer than sporangium. Resembling Didymium squamulosum, in the wall of the sporangium breaking up into large detached patches, but readily distinguished by the absence of a columella, and the thin, coloured stem.

Didymium proximum, B. and C. (figs. 227-229). D. nigripes var

Sporangium globose, white or pallid, sprinkled with lime, mostly in the form of stellate crystals; stem more or less longitudinally wrinkled, subequal, rufous, erect, expanding at the base into a small hypothallus; columella subclavute, whitish, reaching one-third the height of the sporangium; capillitium dense, threads colourless, sometimes rough with projecting granules; $3-4 \mathrm{~mm}$. thick at the base, bifurcating and anastomosing laterally to form an irregular reticulation, often dilated and flattened at the axils; spores globose, pale dirty lilac, smooth, 9-12 $\mu$ diameter.

Didymium moximum, B. and C., Grev., vol. ii., p. 52 (1873); Rost., Mon. App., p. 23; Sacc., Syll., no. 1308.

Didymium pusillum, B. and C., Grev., ii., p. 53.

On dead pine leaves and on herbaceous stems. Carolina.

(Types in Herb. Berk., nos. 10760 and 10764.)

Scattered, $2-25 \mathrm{~mm}$. high, columella large, usually more or less clavate, sometimes irregularly fusiform. Owing to a slip of the pen, Berkeley says, in describing $D$. pusillum, "columella nulla," yet the large columella is shown in Berkeley's sketch, and the type specimen is identical with that of D. proximum. 
Spores smooth, or with sometimes the slightest suggestion of granulation under a $\frac{2}{1 \%}$ objective.

Didymium pezizoideum, Mass. Trichamphora pezizonder Junph

Sporangia stipitate, discoid, pezizaeform, greyish-white, wall single, becoming furfuraceous; stem subulate, curved above, brownish, smooth, expanding at the base into a small, shining, closely adnate hypothallus; threads of the capillitium combined to form a net, spores smooth, violet, $8 \rightarrow 9 \mu$ diameter.

Trichamphora pezizoidea, Jungh., Fl. Cr., Java, p. 12, t. 2, f. 9.

Chondrioderma pezizoideum, Rost., Mon., p. 424, f. 122 ; Cooke, Myx. Brit., fig. 122; Sacc., Syll., 1256.

On rotten trunks. Javả.

Didymium platypus, Hanzl. Didymium squamulosus: Fr.

Greyish-white, primrose, sporangia scattered, convex above, deeply umbilicate below; stem cylindrical, dilated in a discoid manner at the apex; spores globose, smooth, blackish, $8 \mu$ diam., capillitium scanty, formed of black tubes connected in a reticulate manner, columella absent.

Hanzl. Ein neue Myxog. typus in Just. Bot. Jahresbericht, 1872, p. 155; Sacc., Syll., 1326.

Agaricus platypus, Bischoff (sec. Hanzl.).

On putrid plant stems. Hungary.

\section{* * Spores warted.}

Didymium echinospora, Mass. (n. sp.). Physarum reniforme Lister

Sporangia globose, usually with a shallow umbilicus below, wall membranaceous, almost colourless, with a dense coat of white amorphous particles of lime, upper portion breaking away in flakes during dehiscence, and leaving a permanent cup-like basal portion with torn edges; stem elongated, slender, erect, very slightly attenuated upwards, white, rugulose below; columella absent; capillitium very dense, threads lilac-brown, about $2 \mu$ thick, bifurcating, and towards the apex freely anastomosing 
to form a dense net, with the angles usually triangular; spores dingy purple, globose, warted, 12-14 $\mu$ diameter.

(Type in Herb. Berk., Kew., with Tilmadoche nutans.)

On bark. Ceylon.

Scattered, 1.5-2 mm. high. Bearing a superficial resemblance to Tilmadoche nutans, but distinct in the capillitium, which contains no trace of lime, and in the spores.

Didymium zeylanicam, B. and Br. Tricham pbora pezizor.

Sporangium hemispherico-depressed, with a shallow umbilicus below, wall thin, colourless, frosted with white granules of lime; stem clongated, attenuated upwards, or almost obsolete, brown or yellow, longitudinally wrinkled, filled with small grains of lime, expanding below into a spreading hypothallus; capillitium forning a dense irregular net, threads colourless, very thin; spores dark purple, globose, very minutely verruculose, $7-9 \mu$ diameter.

Didymium zeylanicum, B. and Br., in Journ. Linu. Soc., vol. xiv., p. 84 .

Chondrioderma zcylanicum, Rost., Mon. App., p. 15 ; Sacc., Syll., no. 1254 .

Chondrioderma exiguum, Racib., Hedw., 1889, p. 118.

(Type in Herb. Berk., no. 10770.)

On decayed wood. Ceylon; Poland.

The species described as Chondrioderma cxiguum cannot be separated from the present species; the points of difference given by Raciborski only apply to certain individuals which, from an examination of the type, is a variable species.

\section{Didymium obrusseum, B. and C. var obrusseum,}

Sporangium white or pale yellow, almost globose, sometimes slightly umbilicate below, wall very thin, with little or no lime, often iridescent when empty; stem attenuated upwards, flattened and distorted below, weak and drooping, bright ycllow, expanding at the base into a very thin, irregular hypothallus of the same colour; columella absent; capillitium rather scanty, threads 
thin, colourless, repeatedly forked and joined laterally to form a loose, irregular net; spores globose, dingy lilac, very minutely verruculose, 8-10 $\mu$ diameter:

Didymium obrusseum, B. and C., Grev. (1873), vol. ii., p. 53.

Physarum obrusseum (B. and C.), Sacc., Syll., 1195 (in part).

\section{- (Type in Herb., Kew.)}

Exsice.-Fung. Cubenses Wrightiani, 532.

On twigs, leaves, \&c. Cuba; United States.

Gregarious, stem flaccid, irregelar and flattened below, very thin above, about $2 \mathrm{~mm}$. long, hypothallus very thin and shining.

Didymium pertusum, Berk. Didymium nigripes var. xanthopu:

Scattered. Sporangium globose or depressed, generally more or less umbilicate, white, frosted with minute crystals of lime; stem elongated, slightly attenuated upuards, rufous; columella entirely absent; threads of capillitium very thin, colourless, variously branched and combined to form a net; spores globose, dirty lilac, verruculose, $10-13 \mu$ diameter.

Didymium pertusum, Berk., Eng. Fl., vol. v., p. 313 ; Cooke, Myx. Brit., p. 35 ; Sacc., Syll., 1317.

(Type in Herb. Berk.)

On dead herbaceous stems. Appin, N. B.

Scattered, varying from $2.5-3 \mathrm{~mm}$. high. There is no trace of a columella, although after dehiscence the basal persistent portion of the sporangial wall falls down, and this under a pocket-lens might be mistaken for a columella. The threads of the capillitium anastomose freely and form a very irregular, scanty network. The stem is more or less longitudinally rugulose, and filled with amorphous particles of lime.

\section{Didymium eximium, Peck.}

Sporangia subglobose, slightly or not at all umbilicate below, grey, frosted with stellate crystals of lime; stem elongated, erect or slightly curved above, almost equal, slender, pale yellowishbrown, darker towards the base, which expands into a minute hypothallus, slightly, rugulose, filled with amorphous particles 
of lime, as is also the orbicular, depressed, pale columella; capillitium colourless, threads very slender, combined into a dense irregular net; spores globose, brownish-lilac, minutcly warted, 8-11 $\mu$ diameter.

Didymium eximium, Peck, in 31st Rep. N. York State Mus., p. 41 ; Sacc., Syll., n. 1314.

Exsicc.-Ellis and Everhart, N. Amer. Fung., Ser. II., 2089.

(Authentic specimen from author in Hb., Kew.)

On dead leaves, herbaceous stems, \&c. U. States.

Scattered or gregarious, from $1-1 \cdot 5 \mathrm{~mm}$. high, stem twice or more the length of the sporangium. Threads of capillitium often more or less dilated at the angles, and rarely with a slightly thickened interstitial portion, which does not however contain lime.

\section{Didymium flavicomum, Mass. (figs. 76-78).}

Sporangium depresso-globose, minutely umbilicate below, pulcycllow, at first frosted with a few scattered crystals of lime; stem elongated, slender, erect or slightly curved near the apex, subequal or attenuated upwards, yellowish-mufous, often darker at the base, which expands into a minute hypothallus, longitudinally wrinkled and containing amorphous granules of lime; columella absent; capillitium pale yellow, threads variously combined to form a rather dense net, dilated at the nodes, which are without a trace of lime; spores almost colourless, very minutcly verruculose, $9-10 \mu$ diameter.

Physarum flavicomum, Berk., Hook. Journ. Bot., vol. iv., p. 66 ; Sacc., Syll., n. 1193 (in part).

Physarum Berkeleyi, Rost., Mon., p. 10 ๖.

(Type in Herb. Berk., n. 10,782.)

On decorticated wood. Australia (Swan River).

Gregarious, $25-3 \mathrm{~mm}$. high, stem slender, three to four times as long as the sporangium. The present very distinct species has been hopelessly confused by Rostafinski and by Berlese in Saccardo's Sylloge, and the mistakes committed by both can be traced to the modern pernicious system of paying attention to books rather than specimens, always a mistake, and 
more especially so when dealing with diagnoses of microscopic species described half a century ago. The following synonyms by Rostafinski, although absolutely worthless from a scientific standpoint, may be historically interesting.

\section{(Rostafinski's Synonyms.)}

Physarum flavicomum, B., Hook. Journ., p. 66, n. 63 (184ら).

Stylonites fulviceps, Fr., Fung. Natal, p. 33 (1848).

Physarum cupriceps, B. et Rav., Fung. Car. Exs. iii., n. 76 (1855).

Ophiotheca? ..... Roussel. Antil. (1872).

Physarum cupripes, B. and Rav., Grev., p. 65, n. 355 (1873).

Physarum roseum, B. et Br., cfr. Grev., p. 65 (1873).

Didymium elegantissimum, Mass. (n. sp.). D.wigripes ar xonihopus

Sporangia scattered, stipitate, hemispherico-depressed, with a broad, shallow umbilicus below, snow-white, with a dense coating of stellate crystals; stem elongated, equal, rather stout, longitudinally rugulose, bright orange-brown, passing into a small hypothallus of the same colour; capillitium absent; threads $3-4 \mu$ thick at the base, forking at acute angles, here and there anastomosing to form irregular portions of network, most of the main branches with numerons small nodulose swellings at regular intervals, giving a moniliform appearance, pale and lilac-brown below; spores globose, $8-10 \mu$ diameter, minutely warted, pale lilac.

Physarum striatum, Fr., Syd. Myc. March., 490 (Kew copy).

On twigs and leaves. Britain (Scarboro'); Germany.

About $1.5 \mathrm{~mm}$. high. Stem two or three times as long as sporangium. Bears a superficial resemblance to Didymium pertusum, Berk., from which it is readily distinguished by the denser capillitium and the moniliform thickening of the threads.

B. Sporangium sessile.

Didymium leptotrichum, Mass. "

Sporangia venulose or irregular, depressed, wall single, 
covered with minute squamules of lime; columella absent; threads of the capillitium very slender (08, $3 \mu$ diam.), forming a flaccid, very dense net; spores blackish-brown, verruculose, $12,5-13,2 \mu$ diameter.

Chondrioderma leptotvichum, Racib., Myx. Crac., p. 7, f. 4; Sacc., Syll., 1267.

Poland.

Removed from Chondrioderma on account of the furfuraceous and not porcelain-like wall of the sporangium.

Didymium Listeri, Mass. (figs. 97-101). D.dy lms un d...

Plasmodium mulvinato-compressed, in large, irregular, scattered patches; outer wall white, with a thick layer of stellate crystals of lime, rather fragile, breaking away in irregular patches; inner wall very thin; columella absent; capillitium dense, threads purallel, without free encls, often forming acute-angled dichotomies and connected by transverse bars, dark brown, usually branched near the paler tips that are attached to the wall'; spores globose, dingy lilac, minutely warted, $8-10 \mu$ diameter.

"Didymium dnbium, Rost.," Lister in Herb., Kew.

On dead leaves. Britain (Lyme Regis).

The present species superficially resembles $D$. dubium, but is quite distinct in the copiously anastomosing threa ls of the capillitium which are entirely destitute of free, curved, spinelike branches. Plasmodia $3-7 \mathrm{~mm}$. across.

Didymium Tussulaginis, Mass. L. s.2vam vlusum Tr.

Sporangia sessile on a broad base, hemispherical or irregular and plasmodiocarp, wall thin, pinkish-grey, more or less iridescent, with minute, scattered crystals of lime, dehiscing irregularly; capillitium well-developed, springing from the base of the sporangium, threads repcatedly branching in a dichotomous manner, rarely anastomosing, with sccuttered, small suellings usually containing one large or two to four small crystals of lime; spores black-brown in the mass, pale brown with a lilac tinge by transmit:ed light, globose, very minutely verruculose or quite smooth, 12--14 $\mu$ diameter. 
Didymium Cookei, Raunk., Myx. Dan., p. 109, t. 5, f. 5 .

Physarum tussilaginis, B. and Br., Ann. Nat. Hist., n. 1597; Cke., Myx. Brit., p. 16.

Chondrioderma Coolei, Rost., Mon. App., p. 17.

Exsicc.-Cke., Fung. Brit., Ser. I., 526 (as Badhamia capsulifer); Cke., Fung. Brit., Ser. II., 206 ; Thum., Myc. Univ., 1100 ; Vize. Micro-fungi Brit., 1 and 101.

\section{(Type in Herb., Kew.)}

On the under surface of living leaves of colts-foot, Tussilago farfara. Britain (Cheshire); Denmark.

A very remarkable species, not agreeing in important points with any established genus, scattered or in groups of $2-4$, $1 \cdot 5-3 \mathrm{~mm}$. across. Apparently quite normal in its development, and not accompanied by any other species, it occurred in abundance for several years in succession in Cheshire, and has also been found in Denmark. In a note attached to the specimens in the Kew Herbarium, Mr. A. Lister says, "The whole appearance conveys the impression that it may not be a stable form, and the habit is so peculiar." Of course it is a matter of opinion as to whether the appearance described above can afford any clue as to stability, but certainly many species occur on living plants.

The presence of lime in the capillitium prevents the present species from being a typical Didyminu or Chondrioderma; the lime is too scanty and the capillitium too slender for a Physarum.

\section{Didymium anomalum, Mass.?}

Plasmodium venulose, areuate or variously contorted, very convex, surface minutely granulose; columella very strongly developed, with a broad base resting on the substratum, arcuate, following the shape of the plasmodiocarp; threads of capillitium very delicate, thin, colourless, flaccid, forming a dense net; spores minutely verruculose, yellow, 11-13 $\mu$ diameter.

Chondrioderma anomalum, Rost., Mon., p. 169; Sacc., Syll., 1263.

Russia. 
The granulose wall of the sporangium separates the present species from the genus Chondrioderma.

\section{Didymium dubium, Rost. (fig. 102).}

Plasmodium pulvinate, arcuate, in crowded clusters, the outer wall white, with stcllate crystals of lime, breaking avay from inner wall in ivregular picces; threads of capillitium rigid, rarely forking, forming a loose net, furnished with curved spines, spores obscure violet, minutely vervuculosc, 10-11 $\mu$ diameter.

Didymium dulium, Rost., Mon., p. 153; Sace., Syll., n. 1298.

Britain (Lyndhurst); Bohemia.

\section{Sub-Gen. Atricha.}

Capillitium obsolete; columella absent.

The two species constituting the present subgenus are undoubtedly degenerate species of Didymium, characterized by the very rudimentary condition, or entire absence of the capillitium.

Didymium sinapinum, Cooke (figs. 167, 168). P.virescens litm.

Clavate, subcylindrical, or more or less irregular, wall brittle with lime, at first compact, then brecking up into bright yellow, casily detuched particles, becoming irregularly ruptured at the apex, basal attenuated stcm-like portion dcorlicr, often with a purple tinge; hypothallus spreading, thin; mass of spores blackish-purple; spores globose, dingy lilac, minutely worted, $7-9 \mu$ diameter.

Dirlymium sinapinum, Cooke, Brit. Myx., p. 33, fig. 245; Sace., Syll., n. 1319.

\section{On leaves. Wales (Forden).}

Growing in isolated patches, gregarious or crowded, springing from a common hypothallus, sporangia $1-1.5 \mathrm{~mm}$. high, usually more or less clavate, now and then irregularly lobed and forming a small aethalium consisting of two or three sporangia, bright sulphur-yellow; in rare instauces a few very thin, bifur- 
cating threads are present, but in most sporangia there is no trace of a capillitiuin.

\section{Didymium flavidum, Peck. P. citrinellum Peck,}

Sporangia globose, or broadly obovate, sessile on a broad or narrow base, wall brittle with lime, rugulose, sulphur-yellow, sometimes with a tinge of orange, becoming irregularly ruptured at the apex, or the apical portion breaking away in an irregularly circumscissile manner, basal half persistent; mass of spores blackish-violet, spores globose, dingy lilac, very minutely verruculose, $10-12 \mu$ diameter.

Didymium flavidum, Peck, 28th Report Staţe Mus., N. Y., p. 54 .

Physarum flavidum, Peck, Berl., Sacc., Syll., n. 1215.

(Authentic specimen from Peck, in Herb., Kew.)

On wood. United States.

Scattered or gregarious, about $5 \mathrm{~mm}$. diam., springing from a very thin hypothallus; capillitium consisting of a few scattered, very thin, bifurcating threads, or most frequently entirely absent.

Owing to imperfect diagnoses and absence of type specimens, the following cannot be arranged in their respective seetions.

\section{Didymium tenerrimum, B. and C.}

Physarum polyeephalum Sihwein

Sporangium globose, white, venulose, umbilicate below ; hypothallus obsolete; stem elongated, thickened below, pallid, hyaline; threads of capillitium colourless; spores black.

Didymium tenerrimum, B. and C., Linn. Soc. Journ., vol. x., p. 348.

Didymium obrusseum, Sacc., Syll., n. 1195 (in part).

On leaves of grass, nearly allied to D. obrusseum, B. and C. Cuba.

The present species is given as a synonym of D. obrusseum, B. and C., in Saccardo's Sylloge, but as the authors considered the two species to be distinct, and as no specimen exists in Berkeley's Herbarium, I have considered it advisable not to 
combine the two, as the present species appears to differ in the absence of a hypothallus.

\section{Didymium Weinmanni, Fr.?}

Sporangia turbinate, very fragile, covered with grey meal, stem short, with a yellow tinge, columella absent; spores blackish.

Didymium Weinmanni, Fr., S. M., iii., p. 121; Sacc., Syll., n. 1331 .

On living herbaceous stems. Russia.

Minute, closely gregarious, and often arranged in lines; stem equal, expanded at the base; sporangia membranaceous, oblong or pyriform, covered with grey meal. (Fr.)

\section{Didymium humile, Hanzl.}

Sporangia applanate, grey, pruinose, apex slightly, below deeply umbilicate; stem cylindrical, brown, short; capillitium of simple, tortuous, smooth, brown threads ; spores brown, $6-7 \mu$ diameter.

Hanzl. Ein neue Myx. types, in Just. Bot. Jahresb., 1872, p. 155 ; Sacc., Syll., 1324.

Hungary.

\section{Didymium fulvipes, Fr. ?}

Stem compressed, sulcate, foxy-vermilion ; sporangium globose, delicately villose, grey.

Didymium fulvipes, Fr., Stirp. Femsj., p. 83 ; Fr., Gast., p. 24; Sacc., Syll., 1323.

Sweden.

Stem and hypothallus resembling those of Hemiarcyria mubiformis, very unequal, compressed, subconfluent, longitudinally sulcato-rugose, $2 \mathrm{~mm}$. and more in length; sporangium globose, or slightly depressed, obtuse, often confluent, with a very delicate grey villuse covering; columella absent; threads brown. (Fr.)

The villose covering of the sporangium alluded to by Frics would in all probability consist of a very subtle coating of a pulverulent nature. 
Didymium versipelle, Fr. Lepidoderma tiquinum Rost.

Sporangia lenticular, umbilicate below, at first white, pruinose, becoming polished, chestnut, stem conical, rugose, pallid fulvous; columella brown; spores smoky-black.

Didymium versipelle, Fr., Syst. Myc., iii., p. 117 ; Sacc., 1330. Sweden.

Stem about $2 \mathrm{~mm}$. long, conical, wrinkled, sporangium depressed, umbilicate, wall thin, whitish-pruinose, then naked and shining, chestnut; dehiscing "by a longitudinal fissure like a bivalve; columella large, globose, brown. (Fr.)

Didymium Fairmani, Sacc. B. inelanospermum Macbr.

Sporangia scattered, sessile, with stellate crystals; columella subglobose, brownish; threads of capillitium hyaline, forming a loose reticulation; spores smooth, $8-10 \mu$.

Didymium Fairmani, Sacc., Journ. Myc., vol. v., p. 180 ; 1.c., vol. v., p. 78.

On leaves of Smilacina bifolia. Syndonville, Orleans County, N. Y.

The diagnosis is altogether inadequate, and it is much to be regretted that the seventeenth century style of description should be resuscitated at the present day. Professor Saccardo's description is thoroughly bad, inasmuch as it does not describe anything.

Didymium erythrinum, Berk. Physarum pulcripes Peek.

Stem equal, vermilion, as is the globose sporangium, spores black, flocci white.

Berk., Grev., vol. ii., p. 52; Sacc., Syll., 1322.

The pulverulent matter with which the peridium is clothed soon rubs off.

As there is no specimen of the above species in Berkeley's Herbarium, I am unable to add to the above meagre description.

Didymium angulatum, Peck. I. Squa wo losum

Sporangia delicate, subglobose, whitish, externally mealy with numerous granules and crystals of lime; stem short, 
whitish ; columella subglobose, white or pale yellow; capillitium sparse, delicate, whitish or slightly coloured; spores irregular, angular, blackish in the mass, $00035^{\prime}-0005^{\prime}$ long.

Didyminm angulatum, Peck, 31st Report, State Mus., p. 41; Sacc., Syll., 1312.

Fallen leaves. Adirondack Mountains. Aug.

I have no knowledge of the present species except from the above description from Peck.

Didymium Paraguayense, Speg. Cratevi um parags

Sporangia at first globose or elliptico-elongated, $5-1 \times 5 \mathrm{~mm}$., sessile, rarely shortly substipitate, deep violet, springing from a brown, mucedinous, very thin hypothallus, then hemispherical or reniform, 1-2 $\mathrm{mm}$. long by $8-1 \mathrm{~mm}$. high, sessile, subrepens, wall white, thick, cracked or breaking up in flakes; mass of spores fulvons or pale buff; threads of capillitium very thin, hyaline, not evanescent; spores globose, porfectly smooth, pale glive brown, or tobacco-colour, $7-8 \mu$ diameter. Granules of lime very numerous, minute, hyaline, globose, or irregularly angular.

Didymium Paraguayense, Spegazzini, Fung. Guaranit., n. 320.

On fallen leaves and decayed wood. Guarapí.

Didymium daedaleum, B. and Br. Thysarrm gyrosum

Sporangia connate, sinuons, forming a dacdalioid mass, reddishbrown inclining to orange like the stem, sprinkled with white meal; stem connate, as if composed of a bundle of little flat membranes; capillitium white, very variuble in width, being in parts brooul, flut, mombranous; spores violet-black, globose, smooth.

Didymium decdelenm, B. and Br., Ann. Nat. Hist., n. 385, p. 336 (1850); Cooke, Hdbk., n. 1131; Cooke, Myx. Brit., p. 35 ; Sacc., Syll, vii., 1, n. 1313.

In a cucumber frame. Britain.

There is no specimen of the present species in the Berkeley Herbarium, hence I am unable to add anything to the above somewhat imperfect description. 
Didymium connatum, Peck. Physarum connatum Peck

Peridium depressed or subglobose, cinereous, furfuraceous, stipitate; stems mostly connate at the base, tapering upward, longitudinally wrinkled, whitish or cream-colour; spores subglobose, black, 0004 in. in diameter.

Didymium connatum, Peck, 26th Report, N. Y. State Mus., p. 74 .

Physarum polymorphum, Sacc., Syll., vii., 1, n. 1196.

Decaying fungi. Portville; U. States.

The subfasciculate mode of growth is characteristic of this species. (Peck.)

Unknown to me. In Saccardo's Sylloge the present species is given as a synonym of Physarum polymorphum, but the description above does not justify this, and it is very doubtful whether the type specimen has been examined by Berlese.

Didymium flavidum, Peck. P.eitrinellom Peck,

Peridium subglobose, sessile, thin, yellow, clothed with a minute yellow mealiness; spores subglobose, black, '0004' in diameter.

Didymium flavidum, Peck, 28th Report, N. York State Mus., p. 54 .

Physanum flavidum, Berlese, Sacc., Syll., vii., 1, n. 1215.

Bark of dead balsam trees, Abies balsamea. North Elba; U. States.

\section{Lepidoderma, De Bary.}

Sporangia sessile or stipitate or a plasmodiocarp, wall furnished externally with large scales consisting of bicarbonate of lime, superficial or enclosed in lenticular cavities of the membrane; columella generally present.

Rost., Mon., p. 187 ; Cooke, Myx. Brit., p. 43 ; Sacc., Syll., vol. vii., p. 386 .

Closely related to Didymium, and differing only in the fact that the external coating of lime is broken up into large, persistent patches, instead of forming a pruinose coating consisting 
frequently of stellate crystals. Chondrioderma differs in having the external wall of lime forming a polished, porcelain-like crust. In the present genus the carbonate of lime is present in the form of very minute amorphous lumps until near to maturity, when it is dissolved and reappears as bicarbonate of lime deposited in comparatively large tlakes. The same change takes place in Physarum granulatum, Balf. fil., and Mr. Harold Wingate, of Philadelphia, has remarked the same conversion of carbonate of lime into the bicarbonate in Chondrioderma Michelii, and adds, "I feel positive it takes place after the plant has matured, and possibly after it has been dry and again subjected to moisture."

Distrib. Europe; West Indies; Ceylon; Java. Species 8.

\section{A. Spores smooth.}

Lepidoderma stellatum, Mass. (figs. 223-225).

Sporangia spherical, stipitate, slightly or not at all umbilicate below, blackish-bronon, varicgated with rather large white scales, mutured at maturity nearly to the base in a stellate manner, into 4-6 acute, irregular segments; stem rather thick, erect or rarely curved, striate, white; columella hemispherical or subclavate, rather prominent, whitish or tinged yellow; threads of the capillitiun very slender, branching at acute angles, hyaline, flexuous; spores smooth, dingy violet, globose, $10-12 \mu$ diam.

Grevillea, vol. xvii., March (1889).

On rotten wood. Dominica (Ramage).

A very fine and distinct species, $2.5-3.5 \mathrm{~mm}$. high; scattered or gregarious. When young the sporangia are pure white, the outer coat becoming broken up into large white distinct scales as the sporangium expands. Readily recognized by the white stem, colourless capillitium, whitish columella and smooth spores; the mode of dehiscence is also characteristic.

\section{Lepidoderma reticulatum, Mass.}

Sporangia gregarious, sessile on a broad base, convex, circular or elongated, often flexuous and anastomosing in a reticulate 
manner, wall thick, brown with a tinge of purple, furnished with large, scattered, innate, yellow patches of lime; columella absent; mass of spores purple-brown; capillitium very scanty, threads 1-2 $\mathrm{mm}$. thick, colourless; spores globose, smooth, $11-12 \mu$ diameter.

Licca reticulata, B. and Br., Journ. Linn. Soc., vol. xiv., p. 86 (1873).

Didymium reticulatum, B. and Br., in Herb. Berk.

On bark and mosses: Ceylon.

Distinguished from Lepidoderna: Chailletii by the absence of a columella, and from L. Carestianum by the smooth spores and yellow patches of lime on the wall of the sporangium.

Lepidoderma fulvum, Mass. (n. sp.) (figs. 39, 40).

Sporangia stipitate, hemispherical, depressed, umbilicate beneath, fulvous, with scattcred, large, superficial white or yellowish seales; stem stout, equal, or very slightly attenuated upwards, straight or a little bent, longitudinally rugulose, fulvous, hypothallus well developed; columella large, hemispherical, brownish; capillitium copious, threads slender, branched at acute angles, flexuous, brownish-violet; spores globose, smooth, brownish-purple, $10-12 \mu$ diameter, some few much larger.

On mosses, twigs, \&c. Britain (Yorks.); France.

(Type in Herb. Berk., 10,783.)

In groups of 2-4, springing from a firm, well-developed hypothallus, $2 \cdot 5-3 \mathrm{~mm}$. high. Differing from Lepidoderma stellatum, the only other stipitate, smooth-spored speeies, in the coloured columella and stem. The calcareous scales on the pileus very thin, glistening, not so regular and distant as in L. fulvum.

\section{B. Spores warted.}

Lepidoderma tigrinum, Rost. (figs. 41-43).

Sporangia hemispherical, depressed, stipitate, umbilicate beneath, blackish-brown, and furnished with rather distant, large yellowish scales; stem erect, thick and equal, or slightly attenu- 
ated upwards, brownish rust colour or dingy ochre, wrinkled longitudinally; columella brown, globose or hemispherical; threads of capillitium thin, brownish-violet, branches forming acute angles, sometimes united laterally; spores globose, brownish-purple, minutcly warted, 10-13 $\mu$ diam.

Rost., Mon., p. 187, figs. 159, 160 ; Cooke, Myx. Brit., p. 44, figs. 159, 160 ; Saec., Syll., vii., p. 386.

On mosses, wood, \&c. Britain (Teesdale, Yorks. side; New. Pitsligo); France; Germany; Finland; Sweden; Ceylon.

Superficially resembling Lcpiloderma stellata before dehiscence, but known at once by the warted spores, which also separate the present species from L. fulva.

Scattered or gregarious, $2-2.5 \mathrm{~mm}$. high, the base of the stem expanding into a small, irregular hypothallus. Threads of capillitium sometimes with slight granular swellings.

(Rostafinski's Synonyms.)

Didyminm tigrinum, Schrad., t. 6, f. 2,3 (1797); B. and Br., N. H., 383 ; Cke., Hdbk., n. 1121.

Physurum tigrinum, Pers., Syn., 17+ (1801); Fl., Dan., t. 1434 , f. 2.

Physarum squamulosum, Pers., Syn., 174 (1801).

Trichia tigrina, Poir., Ency., viii., 53.

T'vichia squamulosa, Poir., Ency., viii., 53.

Cionium tigrinum, Lk., Hdbk., iii., 410 (1833).

Didymium rufipes, Fr., S. M., iii., 116 (1829).

Lcangium squamulosum, Fr., Stirp. Femsj., 13 (1825).

\section{Lepidoderma obovatum, Mass. (n. sp.) (figs. 45-47).}

Broadly oborate, stipitate; wall dirty ochraceous, thick and firm, studded with large, innate whitish patches of lime; stem short, thick, derk trown, wrinkled; mass of spores blackish with purple tinge; columella abscnt; capillitium springing from the base of the sporangium, threads dingy violet, $3-4 \mu$ thick, equal, repectedly branching in a dicluotomous manner, fumished with a swelling at the base of each dichotomy, the whole com- 
bined into an irregular net; spores globose, dingy violet, minutely warted, $11-13 \mu$ diameter.

On grass and twigs. Sweden.

\section{(Type in Herb., Kew.)}

Plant $1.5 \mathrm{~mm}$. high, $1 \mathrm{~mm}$. diameter; characterized by the obovate sporangium and the swelling at the base of each bifurcation of the capillitium. The minute warts on the spores often show a tendency to become elongated.

\section{Lepidoderma Chailletii, Rost.}

Sporangia hemispherical, adnate by a broat base to a hypothallus, blackish-violet, with numerous shining brown protuberances; columella very small, brownish; threads of the capillitium subviolaceous, with scattered swollen portions, forming a dense net; spores subviolaceous, warted, 10-12 $\mu$ diam.

Rost., Mon., p. 189, fig. 179 ; Sacc., Syll., vii., p. 387 ; Cooke, Myx. Brit., fig. 179.

France; Germany.

\section{Lepidoderma Carestianum, Rost.}

Plasmodiocarp broadly effused, pulvinate, flattened, wall membranaceous, fragile, greyish brown, with numerous rather small white squamules of lime; threads of capillitium brownish grey, yellowish, or almost colourless, branched, and sometimes slightly rough with minute granules of lime; spores globose, warted, brown with tinge of purple, $14-15 \mu$ diam.

Rost., Mon., p. 188 ; Sacc., Syll., vii., p. 387.

Reticularia Carestiana, Rabenh., MS., and in Rab., Fung. Eur., n. 436 .

On twigs. Italy; Belgium.

A peculiar species surrounding thin twigs like a cushion, $1 \mathrm{~mm}$. thick, and extending for $1 \mathrm{~cm}$. or more in length.

Scction doubtful.

Lepidoderma Kurzii, Berk.

Sporangium globose, stipitate, nodding, obscure yellowish- 
green with sulphur-coloured patches of lime; stem slender, attenuated upwards and curved, sulphur-coloured, or whitish, becoming brownish towards the base; hypothallus spreading; spores blackish-brown, globose.

Berk., in Herb., n. 10,78j.

On palm. Java.

The above description, accompanied by sketches, is in Berkeley's Herbarium, but the specimen has disappeared, hence I am unable to supplement the diagnosis.

\section{Spumaria, Pers.}

Aethalium consisting of numerous crowded, irregularly branched sporangia, the whole at first surrounded by a common friable cortex containing granules of lime; sporangia dendritic, the thin walls containing granules of lime; columella central, not containing lime, sending off branches into the lobes of the sporangium; threads of the capillitium forming a dense netwok, extending from the columella to the walls of the sporangium.

Spumarixı, Pers., Disp., t. 1, figs. a, b, c; Rost., Mon., p. 191 ; Cooke, Myx. Brit., p. 45 ; Sacc., Syll., p. 338 ; Zopf, 153.

The present genus, along with Diachaea, form a transition from the Lithodermene to the Columelliferae; showing affinity with the former in the presence of granules of lime in the sporangial walls, and with the latter in the central, elongated columella.

Distrib. Europe; United States; Canada; Australia; S. Africa; Ceylon. Species 1.

\section{Spumaria alba, D. C.}

Common cortex whitish, deciduons; sporangia numerous, elendritic; columella empty, branched, shorter than the branches of the sporangium, capillitium springing from the columella and passing to the wall of the sporangium, branches $2-4 \mu$ thick, forming a dense irregular net, widened at the angles, obscure violet or brownish; spores globose, vervnculose, obscure purple, $10-13 \mu$ diameter.

Spumaric alba, D. C., Flor. Fr., ii., 261 ; Rost., Mon., p. 191, 
figs. 158, 172, 175 ; Cke., Myx. Brit., p. 45, figs. 158, 172, 175 ; Schroeter, p. 120 ; Raunk., Myx. Dan., p. 89; Sacc., Syll., 1338.

Exsicc.-Rab., Fung. Eur., 1323; Lib., Pl. Crypt. Ard., Fasc. II., 179 ; Karst., Fung. Fenn., 497; Fckl., Fung. Rhen., 1471; Syd., Myc. March., 397; Desm., Cr. Fr., ser. I., 768; Kunze, Fung. Sel., 198.

On wood, bark, leaves, twigs, grass, \&c. Britain (Kew, Scarboro'; Carlisle, Capel Curig, Aboyne, N. B.); Germany; France; Belgium; Italy; Hungary; Denmark; United States; Canada; Australia; S. Africa; Ceylon.

The plasmodium often creeps up the stems of grasses for a distance of several inches, forming aethalia 'varying from $\frac{1}{2}-2$ inches or more in length, at first covered with the thick, white, common cortex, which soon falls away, leaving the numerous, crowded, branched sporangia arranged in a dendritic manner, and of a bluish-grey colour. Mass of spores blackish, very copious and pulverulent.

\section{(Rostafinski's Synonyms.)}

Mucilago, 2, Mich., t. 96, f. 2 (1729).

Mucorii, Gled. Meth., p. 160 (1753).

Mucilago crustacea alba, Batt., t. 40, f. 9, H. I. (175̌5).

Mucilago, Hall, n. 2129 (1768).

Byssus bombycina, Retz., V. Handl., 251 (1769).

Mucilago filamentosa, Bonamy., t. 3 (1772).

Reticularia alba, Bull., t. 326 (1791).

Spumaria mucilago, Pers., Disp., t. 1, f. a, b, c (1797).

Reticularia ovata, Var., With. Arr., iv., 1978 (1803).

Spumaria cornuta, Schum., Saell., 1415 (1803); Fl. Dan., t. 1978 , f. 1.

Spumaria alba, D. C., Fl. Fr., ii., 261 (1805); Fr., Syst.

Myc., iii., 25; Eng. Fl., v., 310; Cooke, Hdbk., n. 1103.

Spumaria alba, a. laminosa, $\beta$. cornuta, Fr., S. M., iii., 95 (1829).

Didymium spumarioides, Fr., S. M., iii., 95 (1829).

Diderma spumariaeforme, Wallr., Fl. Germ., 2208 (1833). 


\section{Diachaea, Fr.}

Wall of sporangium without lime externally, but sometimes containing scattered granules on its inner surface, thin, usually with metallic tints; columella either thick and elongated, rigid with amorphous lumps of lime, or more or less rudimentary and represented by an accumulation of lime at base of sporangium; capillitium forming a dense net, springing from the columella or base of sporangium, threads usually coloured, without lime, thickest at the point of origin.

Diachaca, Fries, Syst. Orb. Veg., i., p. 143; Fr., Syst. Myc., iii., p. 155 ; Rost., Mon., p. 190 ; Cooke, Myx. Brit., p. 44; Sacc., Syll., p. 387.

Although placed in a different order by Rostafinski, Lamproderma approaches the present genus so closely, that it is open to doubt whether the two genera, as at present understood, should not be merged into one. The generic diagnoses of the two, as given by Rostafinski, illustrate the two poles of the genus in the larger sense, and read very distinct, but when a complete sequence of the species included in the two genera are examined, then the difficulty of "drawing the line" becomes only too apparent, and the only character that remains is, the presence of lime in the columella and stem in Diachaea, and its absence in Lamproderma. In Lamproderma violacea, Fr., the columella is filled with large vesicles as in Trichia fallax, and in Lamproderma suboencus, B., well-developed granules of lime are by no means rare in the threads of the capillitium; lime is by no means always absent from the capillitium of several species of Stemonitis, and other genera belonging to the order Amaurochacte, the most important feature of which consists in the absence of lime.

Diachaca is as far from being a typical nember of the Calcareae, owing to the entire absence of lime on the surface of the wall of the sporangium, as it is from being typical of the Amaurochuctcae on account of the lime contained in the colunella and stem.

Distrib. Europe; United States; W. Indies; Brazil; S. Africa; India; Australia; New Zealand. Species 5. 
Sub-Gen. Diachaea.

Columella well developed, elongated, rigid with amorphous masses of lime.

\section{A. Spores smooth.}

Diachaea confusa, Mass. (n. sp.).

Gregarious, springing from a thin, irregular, yellowish hypothallus; sporangia elliptico-cylindrical, stipitate, obscure purple, iridescent, stem equal to, or a little shorter than the sporangium, pale ochraccous, subcqual, slightly wrinkled: longitudinally; columella two-thirds the height of the sporangium, dirty pale ochraccous, subclavate, filled with masses of lime, very brittle; threads of the capillitium springing from the columella, much branched and irregularly anastomosing to form a very dense net, about $3 \mu$ thick near the columella, tapering, pale olive or smoky; spores at first in clusters of $6-8$, smooth, globose, $5-6 \mu$ diameter, dingy lilac.

\section{(Type in Herb., Kew.)}

Sporangia $2.5-3 \mathrm{~mm}$. high; distinguished by the ochraceous subequal stem and the small spores in clusters of $6-8$. The capillitium is very dense, and the columella so very brittle that it requires care to see it intact.

On living geranium leaves. Jamaica.

Diachaea leucopoda, Rost. (figs. 165, 166).

Gregarious, springing from a spreading white hypothallus; sporangia elliptico-cylindrical, stipitate, brownish-purple, sometimes iridescent, often subumbilicate below; stem shorter than sporangium, white, thin above, expanding considerably downwards, smooth; passing upwards as a thick, equal or slightly tapering columella about two-thirds the length of the sporangium, white, and filled with granules of lime; mass of spores blackish; capillitium dense, threads springing from the columella where they are $3-4 \mu$ thick, much branched and irregularly anastomosing to form a dense net, becoming thinner and attached 
to the wall of the sporangium, dusky or almost colourless; spores globose, minutely vermuculose, lilac, $7-9 \mu$ diameter.

Diachaea leucopoda, Rast., Mon., p. 190, f. 178; Cooke, Myx. Brit., p. 44, f. 178; Sacc., Syll., n. 1335.

Exsicc.-Rab., Fung. Eur., 434 and 1071; Roum., Fung. Gall., 3174; Klotzsch (Rab.), Herb. Myc., 36 ; Syd., Myc. March., 1900 ; Rav., Fung. Car., 80 ; Desm., Crr. Fr., Fasc. ii., 261; Fckl., Fung. Rhen., 1451; Westendorp, Crypt. Belg., 1260.

On leaves, twigs, \&c. Britain (King's Cliffe, Carlisle, Linlithgow); France; Germany; Belgium; United States; Cuba; Brazil; S. Africa; India; E. Australia.

Varying from $1.5-2 \mathrm{~mm}$. high, characterized by the white, acutely conical stem, and smooth spores not produced in clusters.

(Rostafinski's Synonyms.)

Trichia leucopoda, Bull., t. 502, f. 2 (1791).

Stmonitis elegans, Trent., in Roth., Cat., 220 (1797).

Stcmonitis leucostyla, Pers., Syn., 186 (1801).

Stemonitis lcucopoda, D. C., Fl. Fr., ii., 257 (1805).

Diachaca elcgans, Fr., Stirp. Femsj., p. 84 (1825); Fr., S. M., iii., 156; Berk., Ann. N. H., n. 112; Cooke, Hdbk., n. 1154 , f. 131.

Diechaca leucopoda, Rost., Mon., p. 190 (1875).

Var. cylindrica, Mass.

Sporangium cylindrical, elongated, stem cylindrical.

Exsicc.-Ellis, N. Amer. Fung., 336.

On pine wood lying on the ground. United States.

Differs from the type form in its larger size, $2 \cdot 5-3 \mathrm{~mm}$. "high; the longer cylindrical stem, and elongated, cylindrical sporangium.

\section{Diachaea Hookeri, Mass.}

Sporangia spherical, slightly flattened or umbilicate below, wall thin, pale ochraceous or with a flesh tingc, slightly iridescent, with minute granules in detached patches on the inside; stem 
about equal to sporangium, stout, expanded at the base into a circular hypothallus, longitudinally rugulose, colour of sporangium; columella pale, cylindrical, about half the height of the sporangium, containing irregular masses of lime; threads of capillitium springing from the columella, irregularly branching and anastomosing to form a dense net, attached by its ultimate branches to the wall of the sporangium, threads $3-4 \mu$ broad near the columella, flattened, tapering, pale dirty lilac to colourless; spores globose, minutely warted, brownish lilac, 11-14 $\mu$ diameter.

Diderma Hookeri, Berk., Fl., New Zealand, p. 191, T. CV., f. 12.

Lamproderma Hookeri, Rost., Mon. Append., p. 24.

(Type in Herb., Kew.)

Gregarious on living fronds of Hymenophyllum. New Zealand.

A true Diachaea, as the genus is at present defined, and well marked by the pale coloured globose sporargium, and the large spores.

\section{(Rostafinski's Synonym.)}

Diderma Hookeri, Berk., Fl., New Zeal., p. 191, T. CV., f. 12.

\section{Sub-Gen. Hemidiachaea.}

Columella short or obsolete, and represented by a few lime granules at base of sporangium.

\section{B. Spores with irregular, raised bands.}

Diachaea splendens, Peck (figs. 37, 38).

Sporangia spherico-depressed and umbilicate below, or reniform, solitary or fasciculate on a common stem, deep peacock-blue or purple, iridescent; stem equal to or shorter than sporangium, white, expanding into a vague hypothallus; columella white, cylindrical or reniform, containing lime; capillitium dense, threads brown, anastomosing to form a network extending from the colurnella to the sporangial wall; spores globose, purple- 
brown, with scattered, broad, irregularly-shaped recised bunds of various lengths, 8-11 $\mu$ diameter.

Diachrea splendens, Peck, 30th Report, State Mus. Nat. Hist., p. 50 ; Sacc., Syll., 1336.

On leaves, \&c. United States.

For specimens of the present very distinct and beautiful species, I am indebted to Mr. Harold Wingate, of Philadelphia.

Gregarious, about $1.5 \mathrm{~mm}$. high, evidently allied to Diachace leucopoda, but abundantly distinct in the spore marking, and the short reniform sporangia and columella.

\section{Diachaea subsessilis, Peck.}

Gregarious or crowded; sporangia subglobose, sessile, or with a very short white stem, the walls delicate, iridescent with various metallic tints; columclla obsolete; capillitium and mass of spores violet-brown; spores globose, rough, $\cdot 0004^{\prime}-0005^{\prime}$ in diameter ( = about $12.5 \mu$ ).

Ditchace subsessilis, Peck, 31st Report, State Mus., p. 41.

Fallen leaves. Adirondack Mountains, U. States.

This is a most singular species, and apparently very rare. In its lack of a distinct columella, it departs from the generic cliaracter, but it cannot be placed in the genus Lamproderma, for the same objection would hold there, and besides that, another is found in the presence of lime granules in the stem. Even when no distinct stem is present, a small whitish mass of granules can generally be seen at the point of attachment. The capillitium appears to originate at the base of the sporangium. The spores are larger, but less rough than those of D. splendens. (Peck.)

I have had no opportunity of examining the present species, hence can add nothing to the vague description of the epispore.

\section{Subord. Physarae.}

Craterium, 'Trent.

Sporangia usually distinct and stipitate, wall consisting of two or three distinct layers, dehiscing by a sharply-differentiated 
apical lid, or by an irregularly circumscissile separation of the undifferentiated apical portion of the sporangium, basal portion of sporangium persistent after dehiscence; capillitium of stout threads attached at numerous points to the sporangial wall, combined to form an irregular, rigid network, containing a large quantity of lime which is usually localized in swollen, irregular, often more or less flattened portions; these towards the base of the sporangium are compacted to form an irregular columella.

Craterium, Trent., Obs. Bot. ; Rost., Mon., p. 118; Cke., Myx. Brit., p. 18; Zopf, p. 146 ; Sacc., Syll., vii., 1, p. 355 .

The species of Craterium are more or less gregarious in habit, but rarely crowded, although now and again: specimens occur with the sporangia more or less confluent, the stems remaining distinct. The sporangia persist for a long time after dehiscence, owing to the rigidity of the wall and capillitium, and in this stage resemble in shape miniature wine-glasses. Craterium is closely allied to Badhamia, differing more especially in the double wall and the presence of a columella, and the circumscissile dehiscence.

Distrib. Europe; Algeria; Natal; Ceylon; Tasmania; Brazil; United States. Species 13.

A. Dehiscence by the separation of a distinct lid at apex of sporangium.

Craterium confusum, Mass. (fig. 289).

Sporangia variable in form, cyathiform, infundibuliform, or pyriform, stipitate or rarely subsessile, varying in colour from bright brown, through ochraceous to nearly white, lid sharply differentiated from wall of sporangium, flat or slightly convex, usually chalky-white, rarely ochraceous, deciduous; stem variable in length and depth of colour; capillitium abundant, knots of lime large, irregular, white or yellowish, usually by aggregation forming a more or less distinct columella; spores globose; dirty violet, very minutely verruculose, 8-11 $\mu$ diameter.

Craterium vulgare, Rost., Mon., p. 118, figs. 94, 96; Cke., Brit. Myx., p. 18, figs. 94, 96. 
Craterium pyriforme, Rost., Mon., p. 120 ; Cke., Brit. Myx., p. 19 ; Sacc., Syll., n. 1234.

Craterium minutum, Rost., Mon., p. 120, f. 95 ; Cke., Myx. Brit., p. 19, f. 95; Raunk., Myx. Dan., p. 79.

Craterium pcdunculatum, Sacc., Syll., 1233; Raunk., Myx. Dan., p. 79.

Exsicc.-Cke., Fung. Brit., Ed. II., 208 (as C. minutum); Fckl., Fung. Rhen., 1453; Roum., Fung. Gall., 2957; Syd., Myc. March., 489 ; Desm., Cr. Fr., Ser. I., 369 ; Fckl., Fung. Rhen., 1454 (as Craterium pyriforme).

On leaves, twigs, bark, moss, \&c. Britain (Kew, Weybridge, Penzance, Apethorpe, Bungay, Lyme Regis, Shere, Scarboro', Carlisle, Abergavenny, Appin, Glamis, N. B.); Germany; Hungary; France; Italy; Finland; Belgium; Bavaria; Sweden; United States; Cuba; Brazil; N. Zealand; Australia; Natal; Tasmania.

After a careful examiuation of numerous specimens from Europe and other parts of the world, I find that the only course left is to combine the three species and five varieties acknowledgel by Saccardo, into one species characterized by the sharplydifferentiated operculum, which is usually chalk-white, and flat or slightly convex, and the dull-coloured sporangium. In the above idea I am confirmed, or rather anticipated, by Mr. A. Lister, who, during a critical examination of the Myxogastres in the Kew Herbarium, has attached the following note to the specimen-sheet of $C$. vulgare. "I have added to the collection some specimens of Craterium vulgare, representing a few varieties in form and colour from a heap of dead leaves in my grounds at Lyme Regis. The white form is abundant in such localities, and given in several of the Kew specimens, is the result of age and exposure, on originally more deeply coloured, but pale sporangia. I lave cultivated a large number of sporangia from orange-yellow plasmodium, and gathered many thousands of the ripe fruits during the last three years from this particular heap. Among them I find all the characters given in the description of Rostafinski's three species, C. vulyare, C. pyriforme, and C. minutum, with (as it 
appears to me) all shades of intermediate form. From careful observation of sporangia developed from plasmodium, both in the open air and under bell-jars, I believe that while varying in form and colour, they belong specifically to one species. The plasmodium appears to be always ultimately, of a more or less orange-yellow, though in some stages it is often dirty brown from the quantity of foreign matter beld in suspension. The differences in form and colour of the sporangium are the only characters by which these three species (?) are separated, and these characters vary so much in sporangia rising simultameously, and apparently from the same plasmodium, that, I venture to submit, they cannot be considered as specific.

"In all varieties the wall of the cup consists of two or three layers, the outer smooth, with granules of lime equally distributed throughout its more or less coloured substance, the inner white, and heavily charged with lime, though the lime differs in atnount even in sporangia of the same cluster. The lid is deciduous, and usually paler than the cup, and in most instances distinctly marked off from the rim. In abnormal forms, caused by rapid drying, the lid is often sunk below the rim.

"The capillitium is white, consisting of large knots of lime connected by scanty hyaline threads; these threads are sometimes yellow, when the colour extends over the inner wall. A central aggregation of lime knots or columella is sometimes present. Spores smooth, $5-9 \mu$, bright violet or violet-brown."

The appearance of the epispore depends on the amount of magnification. I find in Mr. Lister's own specimens that under a power magnifying 1200 diameters the epispore is distinctly warted.

\section{(Rostafinski's Synonyms.) \\ (Under C. vulgare.)}

Fungoides infundibiliforme, pendulum, pediculo donatum, Mich., Nov. Pl. Gen., p. 205, n. 10, t. 86, f. 13 (1729).

Craterium peduneulatum, Trent., 1.c., p. 244 (1797).

Craterinm vulgare, Ditm., l.c., t. 9; Nees, Syst., f. 120 ; Chev., Fl. Par., t. 4, f. 26 (1817). 
Craterium leucocephalum, Desm., Cat. 27, non Auct. (1823).

(Under C. pyriforme.)

Craterium pyriforme, Ditm., l.c., p. 19, t. 10 (1817).

(Under C. minutum.)

Peziza minuta, Leers., Fl. Herbor, n. 1085 (1775).

Cyathus minutus, Hoff., Veg. Crypt., p. 6, t. 2, f. 2; Sow., Eng. Fg., t. 239 (1790).

Trichia minuta, Relh., Teste Fr. (1786).

Nidularia minuta, With. (1792).

Sphaerocarpa operculata, Schum., Fl. Saell., n. 1503 (1803).

Physarum turbinatum, Schum., Fl. Saell., n. 1450 (1803).

Craterium leucocephalum, Grev., Fl. Scot., t. 65 (?) (1824).

Creterium minutum, Fr., l.c., iii., p. 151 (1829).

Craterium turbinatum, Fr., l.c., iii., p. 152 (1829).

Arcyria leucocephala, Auct.

\section{Craterium Oerstedtii, Rost.}

Sporangia pyriform, along with the stem blackish-brown, lid convex, snow-white; columella distinct; spores pale violet, 8-10 $\mu$ diameter, smooth.

Craterium Oerstedtii, Rost., Mon., p. 120, fig. 99 ; Cke., Myx. Brit., fig. 99 ; Sacc., Syll., vii., 1, n. 1235.

On wood. Denmark.

Unknown to me. Appears to differ from C. confusum in the darker-coloured stem and sporangium.

Craterium Friesii, Rost. (fig. 265).

Sporangia cyathiform, stipitate, wall smooth, shining, orangerid, licl distiuct from cup, whitish, flattencd, stem very thin, equal, longer than sporangium, red; capillitium dense, knots of lime large, joined by short, hyaline internodes; spores globose, brownish-violet, smooth, 10-11 $\mu$ diameter.

Craterium Fricsii, Rost., Mon., p. 122, f. 105; Cooke, Brit. Myx., f. 10 ว.

Cratcrium nutans, Sacc., Syll, 1237. 
On mosses, decaying lichens, \&c. Britain (Lyndhurst, Hawthornden, Edinboro'); Sweden; Germany.

From 1.5-2 mm. high, sporangia and stem varying from orange to deep blood-red, stem elongated, slender.

\section{B. Apex of sporangium not differentiated into a distinct lid.}

Craterium leucocephalum, Rost. (figs. 298-301).

Sporangia stipitate, conico-cylindrical, pyriform or subglobose, apex rounded and eventually breaking away in a circumscissile manner, upper portion of sporangium whitish and rough with minute, innate particles of lime which eventually fall away, leaving minute pits in the wall, basal portion of sporangium dark reddish-brown, much wrinkled; capillitium dense, knots large, irregular, numerous, usually aggregated in the centre to form a columella, granules of lime colourless, yellow or brownish; spores globose, dull violet or brownish, minutely wartcd, the wart often with a tendency to form anastomosing lines, $8-11 \mu$ diameter.

Craterium leucocephalum, Rost., Mon., p. 123, f. 98, 100 ; Cooke, Myx. Brit., p. 19, f. 98, 100; Raunk., Myx. Dan., p. 80, t. 4, f. 12; Sacc., Syll., 1238.

Exsicc.-Syd., Myc. March., 1500; Fuckel, Fung. Rhen., 1452 ; Roum., Fung. Gall., 1679; Rab.-Winter, Fung. Eur., 2674 .

On leaves, twigs, bark, \&c. Britain (Jedburgh, Chiselhurst, Epping, Gloucester, Wanstead Park, Scarboro', Carlisle, Appin, N. B.); Germany; France; Italy; Denmark ; United States; Brazil.

Plasmodium yellow. Gregarious or scattered, $1.5-2 \mathrm{~mm}$. high, variable in form and length of stem, the upper convex portion of the sporangium breaks away in a circumscissile manner, there is not a differentiated lid as in C. vulgare. The present species is best characterized by the pale upper portion of the sporangium being incrusted with minute particles of white or yellowish lime, and also by the presence of numerous circular discs sunk in the substance of the wall; these discs vary 
in size from $10-50 \mu$ diameter, have the margin more or less grooved, and show indications of lines radiating from the centro to the circumference. These discs occur also rarely in the capillitium threads.

\section{(Rostafinski's Synonyms.)}

Fungoides minimum infundibiliforme, albicans, pediculo donatum. Mich., Nov. Pl. Gen., p. 205, n. 13, t. 86, f. 14 (1729).

Peziza convivalis, Batsch., Elenoh. Fung., p. 121 (1781) (not convivalvis, as erroneously quoted by Rostafinski and Cooke). Stemonitis leucocephala, Pers., in Gmel., Syst. Nat., p. 1467, n. 9 (1791).

Stemonitis cyathiformis, Schrnk., l.c., p. 19 (1790).

Trichia cinerea, Trent., l.c., p. 227 (1797).

Arcyria leucocephala, Hoffm., Fl. Cr. ger., t. 6, f. 1 (1795).

Physarum pedunculatum, Schum., Fl. Saell., n. 1453 (1803).

Trtchicae aureae affinis, Fl. Dan., t. 1314, f. 2 (1810).

Cyathus cinereus, Purt., Brit., iii., n. 1561, t. 35 (1817).

Craterium leucocephalum, Ditnl., l.c., t. 11, Grev., Fl. Scot., t. 65 (1817).

Craterium vulgare, Chev., Fl. Paris, 340, non Ditm. (1826).

Physaruin leucostictum, Chev., Fl. Paris, p. 336, t. 9, f. 29 (1826).

Craterium leucostictum, Fr., l.c., iii., p. 152 (1829).

Cupularia lcucoceptuale, Lk., Hdbk., iii., 421 (1833).

Physurum xunthopus, Wallr., in Sched. (1833).

Craterium acanthopus, Wallr., Fl. Germ., ii., 358 (1836).

Crutcrium deopereulatum, Fr, in Wein., l.c., p. 597 (1836).

Cupularia xunthopus, Rabh., Fl. Cr. Germ., n. 2226 (1844).

Craterizun pruinosum, Corda, Icon., vi., p. 13, t. 2, f. 33 (1854).

Craterium cylindricum, Mass. (n. sp.) (fig. 213).

Scattered or gregarious, stipitate, sporangium cylindrical, elungated, apex rounded, smooth, even, lower portion pale clear $r c l$, white above, upper portion breaking away in a circum- 
scissile manner; stem thin, elongated, red, like base of sporangium; capillitium dense, nodes very large, irregularly angular, filled with yellowish granules of lime, connected at various points by long, very thin internodes not containing lime, combined at the base of the sporangium to form a short columella; spores dirty lilac, globose, smooth, $9-10 \mu$ diameter.

Exsicc._Ellis, North Amer. Fung., exs., n. 1400 (as Craterium leucocephalum).

On twigs, \&c. United States.

Stem about two-thirds the length of the sporangium, 2-2.5 $\mathrm{mm}$. high. Allied to $C$. leucocephalum, but, distinguished by the elongated, narrowly cylindrical sporangium, the long, thin internodes of the capillitium, and the smooth spores.

Craterium aureum, Rost. (figs. 257-261).

Sporangia elliptic-oblong, subglobose, or pyriform, stipitate, wall thick, brittle, rugulose, from bright lemon-yellow to reddishorange, upper convex portion breaking away in an irregularly circumscissile manner; stem usually shorter than sporangium, orange-yellow, subequal, expanding at the base into a small hypothallus; capillitium dense with numerous large, irregular knots with yellow or white granules of lime, connected by elongated, thin, empty interinodes; knots aggregated in the centre towards the base to form a columella; spores globose, brownishlilac, minutely verruculose, $8-10 \mu$ diameter.

Craterium aureum, Rost., Mon., p. 124; Cooke, Brit. Myx., p. 20 ; Sacc., Syll., 1239.

Craterium mutabile, Fr., S. M., iii., p. 154.

On leaves, bark, twigs, moss, \&c. Britain (Kew, Carlisle, Lyndhurst, Appin, N. B.); Sweden; Germany; Algeria ; United States.

Plasmodium clear lemon-yellow. Scattered, 1.5 mm. high, distinguished by the rugulose, bright yellow, rigid sporangium, and the long slender internodes in the capillitium, in which respect the present species approaches the genus Physarum. 


\section{(Rostafinski's Synonyms.)}

Trichea aurea, Schum., Fl. Saell., 1461 (1803).

Craterium mutabile, Fr., I.c., iii., p. 154, non S. Gast. (1829).

Cupularia mutabilis, Rab., Fl. Germ., Cr., n. 2225 (1844).

Physarum Duricui, M., Herb.

Craterium rubiginosum, Mass. (figs. 309, 310).

Sporangia globose, broadly elliptical, or obovate, stipitate, dehiscing in a more or less regular circumscissile manner, lower portion of sporangium permanent, reddish-brown, often with a purple tinge, lid or apical portion paler, sometimes whitish; stem about equal in length to sporangium, stout, dark redbrown, passing downwards into a spreading hypothallus; capillitium dense, white, thrcads aggregated in the centre to form a dark-colourcd columella; spores dingy violet, globose, minutely wartcd, warts sometimes more or less arranged in lines, $10-13 \mu$ diameter.

Badhamia rubiginosa, Rost., Mon. App., p. 29 ; Sacc., Syll., vii., n. 1158.

Scyphium rubiginosum, Rost., Mon., p. 148, fig. 115; Cke., Myx. Brit., p. 29, fig. 115.

Exsicc.-Ellis, N. Amer. Fung., 1215.

On wood. Britain (Appin, N. B.); Germany ; France; United States.

Gregarious, $2 \cdot 5-3 \mathrm{~mm}$. high.

(Rostafinski's Synonym.)

Physarum mutriginosum, Chev., Fl. Par., 338 (1826); Eng. Fl., v., 315; Cke., Hdbk., n. 1137.

Craterium dictyospermum, Mass. (figs. 305, 306).

Sporangia globose or obovate, dehiscing in a circumscissile manner or irregularly, lower portion of sporangium permanent, reddish-brown, becoming paler or whitish at the apex; stem about equal in length to the sporangium, rather stout, dark 
brown; capillitium dense, white, threads aggregated in the centre to form a brownish columclla; spores violet with usually a brown tinge, globose, covercd with irregular simple or branched. ridges, which horc and there combine to form an imperfect network, 10-14 $\mu$ diameter.

Badhamia dictyospora, Rost., Mon. App., p. 4; Cke., Myx. Brit., p. 82.

On wood, moss, \&c. Britain (Carlisle); United States.

Gregarious, $2-3 \mathrm{~mm}$. high ; indistinguishable from C. rubiginosum, except by the nature of the markings on the epispore. May possibly prove to be a form of the last-named species.

\section{(Rostafinski's Synonyms.)}

Physarum canum, Klotzsch., Hb. Hook.

Physarum rubiginosum, Berk., Eng. Fl., v., p. 315.

Craterium lilacinum, Mass. (figs. 307, 308).

Sessile, aggregated, globose, smooth, reddish-lilac, capillitium threads variable in diameter, clustercd together in the centre and forming an irregular columella; spores purple, sometimes tinged with brown, glubose, epispore furnished with short, irregular ridges, which sometimes combine to form an irvegular network, $12-16 \mu$ diameter.

Badhamia lilacina, Rost., Mon., p. 145, figs. 108, 109; Cke., Myx. Brit., p. 27, figs. 108, 109 ; Sacc., Syll., vii., n. 1156.

Exsicc.-Syd., Myc. March., 1297 (as Leocarpus vernicosus).

On rotten wood, bark, twigs, \&c. Britain (Carlisle); Germany; United States.

Usually crowded, sporangia seated on a broad base, wall generally smooth, but sometimes rather rough. The present species may eventually prove to be a sessile form of $C$. dictyospermum.

(Rostafinski's Synonym.)

Physarum lilacinum, Fr., l.c., iii., p. 141 (1829). 
Craterium Curtisii, Mass.

Gregarious, sessile, obovate, fixed by a point to a very thin hypothallus, umber-brown, wall thin, smooth or sometines rugulose, soon disappearing at the apex; capillitium dense, nodes large, irregular, separated only by short constrictions, everywhere containing pale brown granules of lime, the nodes become confluent towards the base and form an irregular columella; spores brown with indistinct lilac tinge, globose, minutely warted, $7-8 \mu$ diameter.

Baclhamia Curtisii, Rost., Mon. App., p. 3 ; Sacc., Syll., vii., 1, n. 1159 .

Didymium Curtisii, Berk., Grev., vol. ii., p. 65. (Type in Herb. Berk., n. 10,758.)

Scyphium Curtisii, Rost., Mon., p. 149.

On leaves, grass, \&c. United States.

Sporangial wall very thin, shining, containing very little or no lime. About $1 \mathrm{~mm}$. high.

\section{Craterium Fuckelii, Mass. (n. sp.).}

Sporangia perfectly globose, contracted below into a short, stout stem, every part brownish-ochre, upper portion breaking away in an irregularly circumscissile manner; nodes of capillitium large, angular, combining towards the base to form an irregular columella; spores dirty lilac, globose, rather coarsely warted, $12-14 \mu$ diameter.

Cratcrium mutabile, Fr., in Fuckel's Fung. Rhen., Exs., n. 1455. (Kew copy.)

On wood. Germany.

Distinct from C. cureum in the globose, differently-coloured sporangia, the absence of the long, thin internodes of the capillitium, and the larger, coarsely-warted spores.

\section{Craterium minimum, B. and C.}

Sporangia broadly elliptical, apex convex, breaking away in an irregularly circumscissile manner, pale yellow, becoming 
brownish towards the base, as is also the very short, equal stem; nodes rather scanty, large, irregularly angular, connected at various points by rather long, thin internodes; spores globose, dirty lilac; 7-8 $\mu$ diameter, smooth.

Craterium minimum, B. and C., Grevillea, vol. ii., p. 67; Rost., Mon., p. 125 ; Sacc., Syll., vii., 1, n. 1240.

(Type in Herb. Berk., Kew, n. 10,827.)

On herbaceous stems, \&c. Lower Carolina.

Usually growing in lines on:slender, dead herbaceous stems, .5 up to nearly $1 \mathrm{~mm}$. high; the long, thin internodes of the capillitium are unusual in the genus.

\section{Craterium minutum, Kickx.}

Sporangium stipitate, campanulate, rounded and umbilicate below, 1-1.5 mm. long, of a yellowish clay-colour, tinged brownish or reddish towards the base, sprinkled with very minute, wart-like, paler spots. Operculum the same colour as the upper part of the sporangium. Filaments whitish. Spores globose, black. Stem 2 , rarely $3 \mathrm{~mm}$. high, attenuated towards the apex, wrinkled, often compressed, russet-brown or reddish, springing from a blackish-brown indistinct hypothallus.

Craterium minutum, Kickx, Flor. Flanders, ii., p. 23.

On rotten wood.

The present species is considered as a species of Tilmadoche by Rostafinski, but as his description differs very materially from that of Kickx, the latter is given above. There is no reason, judging from the description alone, to show why Kickx was not quite correct in considering his specimen as a Craterium.

\section{Physarum, Pers.}

Sporangia solitary, plasmodiocarp, or combined to form an aethalium, wall single or of two distinct layers; threads of capillitium springing from all parts of the sporangial wall, combined to form an irregular network, with the numerous nodes or angles very much and irregularly swollen and filled 
with granules of lime, the internodes thin and without lime; deliscence irregular, or by a longitudinal fissure in the plasmodiocarp form.

Physarum, Pers.

Rost., Mon., p. 93; Cke., Brit. Myx., p. 11; Sacc., Syll., vii., p. 336 ; Zopf, p. 144 .

The principal characteristic of the present genus is the presence of numerous large, irregularly swollen nodes, or points of junction of capillitium threads, filled with granules of lime, the internodes, or threads connecting the nodes, being thin and free from lime. Physarum passes by numerous transitional forms into Tilmadoche, which in the typical condition differs in the much fewer and smaller lime-containing nodes of the capillitium.

Distrib. Europe; Africa; Himalayas; Ceylon; Java; Japan; W. Australia; N. Zealand; Tasmania; S. America; W. Indies; U. States. Species, 70.

A. Sporangia stipitate. (Some species included in the present section have sessile forms.)

\section{- Epispore warted.}

Physarum psittacinum, Ditm. (figs. 290, 291).

Scattered, gregarious, or fasciculate, sporangia stipitate, globose, slightly rugulose, lime scanty, grecn, often with orange and deep violet tints; stem elongated, subequal or attenuated upwards, expanding at the base into a small hypothallus, longitudiually rugulose, orange-red; capillitium abundant, consisting of irregularly anastomosing, rather thin threads, connecting numerous large irregular nodes filled with lime, either colourless or usually some shade of orange; columella absent; spores globose, brownish-purple, very minutely verruculose, 7-9 $\mu$ diameter.

Physarum psittacinum, Ditm., Sturm, t. 62; Rost., Mon., p. 104, figs. 75, 76; Cooke, Brit. Myx., figs. 75, 76; Sacc., Syll, n. 1179 (Excl. Syn. Didymium, Ravenslii, B. and C.); Raunk., Myx. Dan., p. 74. 
Dilymium crythrinum, Cke., Grev., 1873.

On bark, \&c. Britain (Neatishead, Norths); Germany; Sweden; France; Italy; Denmark.

Distinguished amongst the red-stemmed species by the green sporangium, and the capillitium consisting of thin, elongated internodes, some of the nodes are flattened, with one or more perforations and contain no lime, numerous others are filled with lime which is usually tinged orange; from $2-2.5 \mathrm{~mm}$. high.

Care must be taken not to confounã the present species with the green forms of Tilmadoche mutabilis.

(Rostafinski's Synonym.)

Physarum psittacinum, Ditm., l.c., t. 62 (1817).

Physarum Schumacheri, Rost. (figś. 287, 288). ?

Scattered or gregarious; sporangia globose, stipitate, warted with granules of lime, ycllowish-olive, often with a tinge of green; stem erect, subequal, usually longer than the sporangium, filled wtth lime, longitudinally rugulose, expanding at the base into a small hypothallus, pale yellow; columella cylindrical, whitish; capillitium dense, forming an irregular net, with numerous rather small knots containing yellowish granules of lime; spores globose, dull violet, minutcly verruculose, 7-9 $\mu$ diameter.

Physarum Schumacheri, Rost., Mon., 99; Cke., Myx. Brit., p. 11; Raunk., Myx. Dan., p. 74.

Physarum citrinum, Sacc., Syll., n. 1176.

Physarum chrysopeplum, B. and C., in Herb.

Exsicc.-Eillis, N. Amer. Fung., n. 1395.

On bark, leaves, \&c. Britain (Neatishead, Carlisle); Germany; Italy; Finland; Ceylon; United States; S. America.

About $2 \mathrm{~mm}$. high.' Capillitium dense, rather flaccid, internodes long, thin, many of the angles flattened and not containing lime, others irregularly branched and filled with yellow granules; columella prominent. The above description applies 
to the typical form, but Rostafinski has given as forms of this species a heterogeneous collection, varying considerably in habit, colour, and size of spores, but all agreeing in having, a columella; how many of these forms are British I do not know, B. chrysopus, which appears to be the same as Physarum citrinum, Schum., has been collected in Yorkshire, and a specimen probably corresponding to $\gamma$. aurantiacum has been met with at Neatishead.

The following are Rostafinski's forms.

Var. a. genuinum. Sporangium yellow or greenish-yellow, $\frac{1}{2} \mathrm{~mm}$. wide, stem yellow; spores $7-8 \mu$ dianeter; granules of lime yellow. This variety is the one described above as the type form.

$\beta$. chrysopus. Sporangium $1 \mathrm{~mm}$. diameter, with the stem golden-yellow; spores $10 \mu$ diameter; granules of lime goldenyellow.

$\gamma$. aurantiacum. Sporangia $\frac{1}{2} \mathrm{~mm}$. diameter; stem brown; spores orange, $11 \mu$ diameter; granules of lime brown.

$\delta$. rufines. Sporangium yellow or orange, sometimes iridescent; stem orange-red; granules of lime yellowish.

є. compactum. Plasmodiocarp veinlike, creeping, short, yellow or golden; columella absent, disappearing with the stem.

Didymium melleum, B. and C., given as a synonym of the present species by Rostafinski, although a Physarum, is quite distinct, as shown by an examination of the type specimen in the Berkeley collection in the Kew Herbarium.

\section{(Rostafinski's Synonyms.)}

Physarum citrinum, Schum., Saell., i., 436 (1803).

P'hysarum uurentiacum, $\beta$. rufipes, A. and S., Cons., 262 (1805).

Physarum rcruncosum, Link, Herb.

Physarum compactum, Ehr., Syl. Ber., p. 21 (1818).

Physarum Schumacheri, Spr., Syst., iv., p. 528 (1×27).

Diderma eitrinum, Fr., S. M., iii., 100 (1829); Cooke, Hdbk., n. 1107.

Diderma rufipes, Fr., S. MI., iii., 101.

Diderma compactum, Wallr., Herb. 
Physarum aureum, $\beta$. chrysopus, Lev., Ann. Sc. Nat. (1846), p. 166.

Physarum flavum, Fckl., Syn., p. 343 (1869).

Dilymium melleum, B. and C., Ceyl. Fung., 751.

Didyminin chrysopeplum, B. and Br., N. A. Fung., 348.

\section{Physarum virescens, Ditm.}

Sporangia stipitate, sessile and crowded, an irregular plasmodiocarp, or an effused aethalium, : wall rongh, yellow, with green or olive tints, stem when present yellow, wrinkled, equal to or shorter than the sporangium; columella, absent; capillitium scanty, knots of lime few, small; spores globese, dingy lilac, very minutely verruculose, $7-9 \mu$ diameter.

Physarum virescens, Ditm., in Sturm, t. 61 ; Rost., Mon., p. 103; Cooke, Brit. Myx., p. 13; Sacc., Syll., n. 1183; Schroeter, p. 128.

Physarum thejoteum, Fr., Gast., p. 21.

Physarum Ditmari, Rost., Mon. Append., p. 13.

Didymium crocco-flavium, B. and Br., Fung. Ceylon, n. 757.

Exisicc.-Fckl., F. Rhen, 1460 (as Physarum anecps, de By).

a. genuinum. Sporangia sessile on a broad base, crowded, rarely scattered.

$\beta$. stipitatum. Sporangia stipitate, stem stout, longitudinally wrinkled, yellow.

$\gamma$. confluens. Sporangia sessile, plasmodiocarp or confluent, and forming a cake-like aethalium.

On leaves, moss, \&c. Britain (Chiselhurst, Bristol, N. Wales, Carlisle); Sweden; Germany; Madras; Ceylon; United States.

Usually sessile and crowded, sporangia subangular from mutual pressure, varying from clear yellow through olive to greenish-yellow, the last being most frequent, and with the scanty capillitium with very few small knots containing lime, marks the species in all its forms.

\section{(Rostafinski's Synonyms.)}

Physarum virescens, Ditm., t. 61 (1817).

Physarum thejoteum, Fr., Gast., p. 31 (1818). 
Physarum anceps, Fckl., Sym. Myc., 343 (1869).

Didymium nectriaforme, B. and C., Grev., 353.

Didymizom eroceo-flavinom, B. and Br., Fung. Ceylon, n. 757.

Didymium lateritium, B. and Br., MSS.

\section{Physarum melleum, Mass.}

Sporangia stipitate, hemispherical, flattened below, wall thin, yellowish-olive or honey-coloured, sprinkled with minute particles of lime; columella small, white; capillitium very dense, snowwhite, nodes numerous, very large, angularly stellate, separated from each other by constrictions only, lime in the form of granules present in every portion; spores globose, pale lilac, minutely verruculose, $6-7 \mu$ in diameter; stem about equal to the sporangium in length, rather thick, equal, white, longitudinally wrinkled, filled with particles of lime, hypothallus absent.

Didymium melleum, Berk. and Broome, Ceylon Fung., n. 751, in Journ. Linn. Soc., vol. xiv., p. 83.

(Type in Herb. Berk., Kew, n. 10,810.)

Plmysarum Schumacheri, Rost., Mon., p. 99 (in part).

Physarum citrinum, Sacc., Syll., vii., 1, n. 1176 (in part).

On dead leaves. Ceylon.

About $2 \mathrm{~mm}$. high. Distinct from $P$. Schumacheri in the dense Bathamice type of the capillitium, smaller spores, and absence of the hypothallus.

\section{Physarum citrinellum, Peck.}

Sporangia subglobose or slightly attenuated at the base, substipitate, wall thin, pale yellow, sometimes with a greenish tinge, rough with numerous crystals of lime, becoming irregularly ruptured at the apex; the very short stem is rufous, longitudinally wrinkled, and expands into a minute hypothallus; columella absent; capillitium rather dense, nodes irregularly stellate-angular, large, containing colourless granules of lime, internodes elongated, very thin, colourless, without lime; spores globose, pale lilac, minutely warted, $7-8 \mu$ diameter.

Physarum citrinellum, Peck.

On mosses. United States. 
From $\frac{1}{2}-\frac{2}{3} \mathrm{~mm}$. high. A very fine specimen named as above was sent to me by Mr. H. Wingate, of Philadelphia. It appears to differ from Physarum chrysotrichum only in the white nodes of the capillitium and the very short stem.

Physarum rufibasis, B. and Br. Physarella oblon qa - Morq.

Scattered or gregarious, stipitate; sporangia globose, dull yellow or tawny, even, sprinkled with minute particles of lime, dehiscing irregularly; stem elongated, slender, tapering upwards, longitudinally furrowed, expanding at the base into a small, circular hypothallus, bright brown, filled'with minjte granules of lime; columella absent; capillitium dense, forming an:irregular network, nodes incrassated, irregularly angular, large, numerous, filled with bright yellow granules of lime, connected at various points by rather thin, long internodes; spores pale lilac, globose, very indistinctly verruculose, $10 \mu$ diameter.

Physarum rufibasis, Berk. and Broome, Fungi of Ceylon, Journ. Linn. Soc., vol. xiv., p. 85.

Tilmadoche hians, Rost., Mon. Append., p. 14 (in part).

Tilmadoche minuta, (Kickx) Berlese, Sacc., Syll., vii., 1, n. 1251 (in part).

(Type in Herb. Berk., Kew, n. 10,800.)

On twigs. Ceylon.

A very fine species, about $2.5 \mathrm{~mm}$. high, resembling a Tilmadoche in the small sporangium and long, slender stem, but the nodes of the capillitium are large and stellately angular.

Physarum flavum, Fries. (fig. 215). P. sulphureum Alb. 9 Schw.

Scattered or gregarious, but not crowded; sporangia globose or slightly depressed; wall rugulose, rigid, bright lemon-yellow, sometimes with a tinge of green, breaking away in irregular patches; stein stout, about equal to sporangium or shorter, bright yellow, very much longitudinally wrinkled, containing amorphous masses of lime, expanding at the base into a small hypothallus; columella absent; capillitium rather dense, nodes irregularly 
angular, internodes rather long, thin; spores globose, pale lilac, very minutely verruculose, $10 \mu$ diameter.

Physarum flewum, Fr., Sym. Gast., p. 22 ; Rost., Mon., p. 100 ; Sacc., Syll., vii., 1, n. 1186.

(The above description drawn up from a specimen named by Fries.)

On mosses, \&c. Britain (Wales); Sweden; Germany.

Usually growing on living mosses, scattered, $1.5-2 \mathrm{~mm}$. high; stem stout. Very closely allied to Physarum Ditmari, Rost., of which the present may possibly prove to be a stipitate form; however, in the absence of such evidence, it is well for the present to retain it as a species.

\section{(Rostafinski's Synonyms.)}

Physarum flavum, Fr., Symb. Gast., p. 22, l.c., iii., p. 135 (1818).

Physarum citrinella, Fries, in Herb.; Kunze.

Cratcrium flavent, Fr., Sm. Veg. Sc., p. 454 (1849).

Physarum Schroeteri, Rost. P.citrinum Sehvmacher

Sporangia stipitate, liemispherical, depressed; stem conical, thick, golden, shining, continued as an obtusely conical columella; threads of capillitium slender, combined to form a dense network, furnished with nodes containing lime; spores spinulose, blackish-brown, 10-12 $\mu$ diameter.

Physarum Schroeteri, Rost., Mon. App. I., p. 419; Karst., Myc. Fenn., iv., p. 102; Sace., Syll., vii., 1, n. 1172.

On leaves and twigs of Almus. Finland.

Physarum brunneolum, Phillips (figs. 221, 222). Mass

Scattered or gregarious, but not crowded, sessile; sporangia globose or subdepressed, wall single, thick, smooth and polished, bright yellow-brown, dehiseing in a stellate manner, the segments becoming reflexed, snow-white inside; columella absent; capillitium very dense, snow-white, nodes very large and numerous, 
irregularly angular, filled with lime, connected at several points by very thin, short internodes; spores globose, dirty lilac, very minutely verruculose, $6-7 \mu$ diameter.

Physarum brunneolum, Phil., in Herb.

Diderma brunneolum, Phillips, Grev., v., p. 114, t. 87, f. 3, $a-f$; Sacc., Syll., vii., 1, 1292.

\section{(Type in Herb., Phillips.)}

On oak bark. San Francisco.

A very beautiful and remarkable species, reaching up to $1 \mathrm{~mm}$. in diameter. Intermediate between the genera Chondrioderma and Physarum, agreeing with the former in the polished, porcelain-like sporangial wall dehiscing in a stellate manner, and with the latter in the structure of the capillitium, whereas the very large and numerous nodes of the capillitium separated from each other by constrictions rather than by true internodes, suggests affinity with the genus Badhamia.

Physarum Ravenelii, Mass. (figs. 234, 235). P. pulchripes Peck

Scattered, stipitate; sporangia perfectly spherical, not umbilicate, dirty brown, sometimes rugulose; stem clongated, rather slender, equal or slightly fusiform, coloured like the sporangium, - filled with granules of lime; columelia absent; capillitium copious, forming an irregular net; nodes small, filled with yellow granules of lime, internodes thick, elongated, colourless, empty; spores dingy lilac, globose, very minutely verruculose, $6-7 \mu$ diameter.

Didymium Ravenelii, Berk. and Curt., Grev., vol. ii., p. 53; Sacc., Syll., vii., 1, n. 1318.

(Type in Herb. Berk., n. 10,771.)

On wood. Sulphur Springs, N. Carolina.

From 2.5-3 mm. high. Remarkable for the dirty brown colour of sporangium and stem. In form and size almost identical with Physarum. Kalchbrenneri. The knots of the capillitium are small and usually elliptical, resembling those characteristic of Tilmadoche, but the capillitium is altogether too robust to admit of the present species being placed in the 
last-named genus. Sometimes two or three sporangia are seated on a common stem, forming a plasmodiocarp.

Physarum scyphoides, Cke. and Balf. (fig. 231).

Sporangia globose or broadly obovate, stipitate, upper portion of wall whitish, rough with amorphous lumps of lime, basal portion bright brown, persistent as a very shallow, irregular cup; stem almost equal to sporangium in length, bright brown, erect, usually attenuated upwards, irregularly wrinkled and often compressed and twisted, expanding at the base into a minute, brown hypothallus; capillitium dense, knots of lime white or yellowish, very numerous, large, irregularly branched, connected by short, thin, colourless portions, becoming concentrated towards the base to form a columella; spore globose, pale lilacbrown, minutely warted, $7-9 \mu$ diameter.

Physarum scyphoides, Cke. and Balf., in Rav., Fung. Amer., Exs., 480 (without description); Mass., Journ. Mycol., vol. v., p. 186, t. 14, f. 7 (1889).

On living leaves, grass, \&c. Darien, Georgia; (Rav., 2407).

(Type in Herb., Kew.)

A very fine species, about $1 \mathrm{~mm}$. ligh, scattered or gregarious ; the upper portion of the sporangium is whitish, with sometimes a suggestion of pink, falling away in patches when mature, and leaving the small, thicker, basal portion in the form of an irregular shallow cup or disc, which, with the character of the capillitium, suggest a leaning towards the genus Craterium.

Physarum Readeri, Mass. (n. sp.). Pnutans, va r levé phar-

Sporangium stipitate, spherico-depressed, plane or slightly umbilicate below, greyish, covered with distinct but closely arranged white, innate flakes of lime; stem equal to or longer than the sporangium, very thick, equal, brown, longitudinally rugulose, expanding into a broad, dark-brown hypothallus, filled with masses of lime and organic matter; capillitium absent, but columel when the sporangium is empty a brown spot is seen at the base which corresponds to the apex of the stem; capillitium 
dense, nodes few, large, angularly stellate, filled with colourless granules of lime, internodes elongated, slender; spores dirty lilac, globose, very minutely verruculose, $15-16 \mu$ diameter.

On wood. Melbourne.

(Type in Herb., Kew.)

Scattered ; $2.5-3 \mathrm{~mm}$. high ; allied to Physamum leucophacum, but quite distinct in the larger spores, thicker, equal stem, and in the large well-developed nodes of the capillitium.

\section{Physarum polymorphum, Rost. P. polycephalum Sehwein.}

Gregarious, stipitate, rarely sessile, sporangia compressed, grey, simple or more or less confluent, obovate, obcordate or lentiform, margin lobed or waved; stem filiform, subulate, or several confluent and forming a membranaceous, sulcate cone, yellowish; threads of capillitium forming an irregular network, white, here and there with angular dilatations; spores subglobose, violetbrown, spinulose, $9-11 \mu$ diameter.

Physarum polymorphum, Rost., Mon., p. 107; Sacc., Syll., vii., 1, n. 1196.

On bark. Cuba; United States.

Sporangia variable in form, often confluent, dark grey, truncate ; stem subulate, strongly longitudinally wrinkled, yellowishpink, rarely simple, usually fasciculate, curved or procumbent; eapillitium strongly developed with angularly-globose dilatations containing lime (Sacc., Syll., l.c.). Unknown to me.

\section{(Rostafinski's Synonyms.)}

Didymium polycephalum, Mout., Ann. Sci. Nat., p. 361 ; Syll., n. 1074 (1873).

Didymium luteo-griseum, B. and C., Grev., p. 65 (1873).

Didymium polycephalum, Rav., cfr. Grev., p. 53 (1873).

Physarum affine, Rost. P.Com préssum. Alb. t Se hw.

Sporangia spherico-depressed or subreniform, white; stem snow-white, opaque, about equal in length to the sporangium; 
capillitium well developed, snow-white; spores pale brownishviolet, epispore thick, warted, $10-12 \mu$ diameter.

Physarum affine, Rost., Mon., p. 94; 'Sacc., Syll., vii., 1, n. 1200 .

On rotten wood. Germany; Poland.

\section{(Rostafinski's Synonýms.)}

(?) Trichia nivea, Fl. Dan., t. 776, f. 4 (1782).

(?) Trichia rugosa, Trent., l.c., p. 288 (1797).

Physarum glaucum, Phillips. P.com pressum AlboSebw

Sporangia subglobose, and depressed or irregularly lobed, more or less umbilicate below, grey, covered densely at first with snow-white particles of lime; stem much shorter than height of sporangium, blackish, thick, longitudinally wrinkled, expanding into a common, firm, pale hypothallus; columella absent; capillitium very dense, snow-white, nodes numerous, large, angularly stellate, connected by very short internodes; spores bright violet, globose, rather coarscly warted, 12-14 $\mu$ diameter.

Physarum glaucum, Phillips, in Herb.

Physarum lividum, Cke., Myxomycetes of the United States, in Ann. Lyc. Nat. Hist., of N. York, vol. xi., n. 12, p. 384.

Didymium glaucum, Phillips, Grevillea, vol. v., p. 113, t. 88, f. $6, a-c$; Sacc., Syll., vii., 1, n. 1315.

(Type in Herb., Phillips, examined.)

On dead branches. California.

Scattered or gregarious, up to $1 \mathrm{~mm}$. across, stem sometimes obsolete. Certainly not synonymous with Physarum lividum as supposed by Cooke, but much more nearly allied to Physarum nephroulcum, from which it is distinguished by the very dense capillitium of numerous large nodes only separated from each other by constrictions, hence every portion contains granules of lime as in the genus Badhamia.

Physarum cupripes, Berk. and Rav. P. flaricoum um Berk Sporangia subglobose, umbilicate below, dark grey, often with 
a purple tinge; stem elongated, slender, attenuated upwards, straight or slightly bent above, copper-colour, longitudinally wrinkled, filled with masses of lime and organic matter, usually expanding at the base into a small, circular hypothallus; columella absent; threads of capillitium numerous, thin, combined to form an irregular, dense net, swollen elliptical portions containing yellowish granules of lime, numerons, small, either formed at the angles of bifurcation or. interstitial; spores globose, pale lilac, minutely warted, 9-12 $\mu$ diameter.

Physarum cupripes, B. and R., Grevं., vol. ii., p. 65.

(Type in Herb. Berk., Kew, n. 10,779.)

Physarum Berkeleyi, Rost., Mon., p. 105 (in part).

Physarum flavicomum, Sacc., Syll., vii., 1, n. 1193 (in part).

Exsicc.-Rav., Fung. Car., n. 76 (under the name of Physarum cupriceps, B.).

Berkeley's type specimen is a portion of the same gatbering issued in Ravenel's Exs., quoted above, and possibly Berkeley in sending Ravenel the name, wrote cupriceps instead of cupripes; however this may be, it is certain that the two names refer to the same species. The present species has been hopelessly confused with others by Rostafinski.

The following note accompanied Ravenel's specimen to Berkeley.

"At first a yellowish-green mucus, spreading on the surface 12-18 in. square, interlaced with veins. On these veins small clavate pedicels arise of the same colour, the heads becoming thicker and assuming finally the subspherical form, changing to lilac-blue."

On dead wood. United States.

Gregarious, 2-2 5 $\mathrm{mm}$. high.

Physarum nefroideum, Rost. P. comnatum Listev

Sporangia longitudinally compressed, circular in outline, but owing to the umbilicus at the base, reniform, minutely cinerea furfuraceous, scarcely $1 \mathrm{~mm}$. broad; stem $\frac{3}{8}-1 \mathrm{~mm}$. long, cylindrical, slightly striate, brown; columella almost obsolete; 
threads of capillitium hyaline, here and there with irregular swellings containing lime, internodes long, slender, some of the nodes empty; spores globose or angularly subglobose, $11-13 \mu$ diameter, blackish-violet, minutely verruculose.

Physarum nefroideum, Rost., Mon., p. 93, figs. 80-82; Cke., Brit. Myx., figs. 80-82.

Physarum compressum, Sacc., Syll., vii., 1, n. 1167.

On leaves, rotten wood, \&c. Britain (Lyndhurst, New Forest); Germany; Italy.

Closely allied to P. Phillipsii, but differing in the structure of the capillitium, the nodes containing lime are much smaller, the internodes long and slender, and many of the nodes are empty and collapsed, or contain air only and not lime.

Physarum candidum, Rost. P.compressum. Hbrsolme

Sporangia strictly or irregularly globose, sessile or stipitate, dehiscjng irregularly, wall charged with lime, snow-white; stem white, elongated, plicate, $1 \mathrm{~mm}$. high, rigid, crustaceous, capillitium with snow-white roundish nodes containing lime; spores pale violet, muricate, $12-15 \mu$ diameter.

Physarum candidum, Rost., Mon., p. 96 ; Sacc., Syll., vii., 1, n. 1170.

On rotten wood. Juan Fernandez.

Physarum simile, Rost. P.nueleatum Rex.

Gregarious, stipitate, sporangia globose, grey, densely covered with small white lumps of lime, rigid; stem usually twice as long as sporangium, equal, or slightly thickened below, and passing into a small, orbicular hypothallus, yellowish, sometimes with a pink tinge, rigid, filled with particles of lime, usually longitudinally wrinkled; columella subcylindrical, whitish, onefourth the height of the sporangium or less; capillitium dense, threads thin, colourless, forming an irregular network, swellings of nodes or interstitial parts small, elliptical or triangular, with colourless or yellowish granules of lime; spores dingy lilac, very minuted vervuculose, $7-8 \mu$ diameter. 
Physamum simile, Rost., Mon. Append., p. 6 (species founded by Rostafinski on a specimen in Herb. Berk.); Sacc., Syll., vii., $1, \mathrm{n}, 1175$.

Physarum Petersii, var. Farlowii, Rost., Mon. Append., p. 6 (specimen named by Rostafinski in Herb. Berk.).

Exsicc.-Ellis, N. Amer. Fung., n. 1120.

On wood, moss, \&c. United States.

Closely resembling $P$. Petersii, differing in the grey sporangium. About $1.5 \mathrm{~mm}$. high.

Physarum leucopus, Rost. (figs. $60-62$ ). Link

Sporangia globose, broadly ellipsoid or a little depressed, stipitate or sessile, rarely elongated and flexuous or anastomosing, wall at first covered with a continuous, snow-white coat of lime, which soon becomes broken up into smooth, innate patches; stem variable in length, white, containing lime, straight, brittle, slightly thinner upwards, longitudinally rugose, passing into a more or less evident hypothallus; columella absent; capillitium strongly developed, snow-white, with numerous large, irregularly branched knots, containing lime in small granules; spores globose, dingy lilac, rather coarsely warted, warts almost black, 9-12 $\mu$ diameter.

f. stipitatum. Stem present, length variable, in the typical form, equal to, or longer than, the sporangium.

$f$. sessile. Stem very short or entirely absent, when the sporangia are sessile on a broad base, sometimes confluent, elongated, sinuous, or anastomosing irregularly.

Physarım leucopus, Rost., Mon., p. 101 ; Cke., Myx. Brit., 12 ; Schroeter, p. 129; Karsten, Myc. Fen., p. 102 ; Sacc., Syll., vol. vii., pt. I., n. 1188.

Physarum leucophaeum, $\gamma$. flexuosum, Cooke, Myx. Brit., p. 15. Exsicc.-Rab., Fung. Eur., 335 (as Physarum albipes); Cooke, Fung. Brit., Ed. II., 519.

On wood, moss, \&c. Britain (Highgate, Carlisle); Germany; Finland; Sweden; S. Africa; S. America; Ceylon; Australia.

A somewhat rare species, often represented in Herbaria by 
Didymium squamulosum, which differs in the large, white calumella. Distinguished from sessile forms of Physarum leucophaeum, by the coarser capillitium furnished with numerous large nodes, and the slightly larger and more coarsely .warted spores.

\section{(Rostafinski's Synonyms.)}

Didymium leucopus, Link, Diss., 2, p. 42 (1809).

Physamum bullatun, Link, Diss., 2, p. 42 (1809); Ditmar, t. 22 .

Physarum albopunctatum, Link, Herb.

Diulymium leucopus, Fr., S. M., iii., 121 (1829); Engl. Fl., v., p. 313; Cke., Hdbk., n. 1127.

Physarum ramentaceum, Fr., in litt. ad Wein (1836).

Physarum leucophaeum, Fr. (figs. 63-66 and 96). P. Ileucophaeum.

Sporangia subglobose, usually a little depressed below, stipitate or sessile, wall thin, with irregular, white, innate patches of lime, dohiscing irregularly; stem usually longer than the sporangium, erect, slightly attenuated upwards, longitudinally rugulose, browon, paler above, passing into a dark hypothallus; capillitium dense, colourless, anastomosing very irregularly, threads thin, often flattcned at the angles which ravely contain lime; spores globose, dingy lilac, minutely warted, $8-10 \mu$ diameter.

$f$. fasciculatum. Stems confluent.

f. scssile. Stem very short or entirely absent, sporangia scattered or confluent, regular or sometimes elongated and anastomosing.

Physarum leucophacum, Fr., Symb. Gast., p. 24; Rost., Mon., p. 113, figs. 77, 78, and 89 ; Cooke, Myx. Brito, p. 15, figs. 77 78, and 89 ; Sacc., Syll., n. 1192; Schroeter, 129; Raunk., Myx. Dan., p. 75.

Didymium pruinosum, B. and C., Cuban Fungi, n. 530.

\section{(Type in Herb. Berk.)}

On leaves, twigs, bark, moss, \&c. Britain (Queen's Cottage grounds, Kew; Hampstead, Bristol, Deal, Scarboro', Carlisle, 
Edimburgh); France; Germany; Italy; Hungary; Denmark; S. Africa; Australia.

About $1.5 \mathrm{~mm}$. high; stem, when perfect, dingy brown, slightly attenuated upwards; the sessile and irregular forms are distinguished from Physarum cincrcum by the dense, irregular capillitium having most of the angles flattened and rarely containing lime.

Var. violascens, Rost. Sporangium subglobose or compressed, wall thin, iridescent, with violet ar reddish tints, with very few small, innate patches of lime, or these may be entirely absent; stem short or equal to sporangium, stout, expanding at the base into a small hypothallus, yellowish, darker below, strongly wrinkled longitudinally; capillitium and spores as in the type.

Physarum lcucophaeum, $\beta$. violascens, Rost., Mon., p. 113; Cke., Myx. Brit., p. 1 .

On moss. Epping Forest.

(Rostafinski's Synonyms.)

Sphacrocarpus albus, Bull., p. 136, var. 3, 4 (1791).

Trichia filcmentosa, Trent., p. 227 (1797).

Physarum confluens, Link, Diss., ii., 42 (1809).

Physarum connexum, Link, Diss., ii., 42 (1809).

Physar"um hypnorum, Link, Diss., ii., 42 (1809).

Physarum albopunctatum, Link, Herb.

Physarum clavus, Ehr., Herb.

Physarum conglobatum, Ditm., t. 40 (1817). .

Physarum leucophaeum, Fr., Sym. Gast., p. 24; Syst. Myc., iii., 132 (1818); Cooke, Fung. Brit., ii., n. 519.

Didymium melanopus, $\beta$. clavus, Wallr., non Fries (1833).

Didymium terrestre, Fr., in Weinm. (1836).

Physarum albipes, De Bary, not Link (1859).

Physarum striatum, Fckl., Sym. Myc., 342 (1869).

Didymium .hemisphericum, Fckl., Sym. Myc., 341 (1869).

Physarum granulatum, Balf. fil. (figs. 68-70). P.nutans var. levcophaeum. Liste

Sporangia stipitate, globose, sometimes slightly flattened below, grey, with small innate granules of lime, and having in 
addition a sprinkling of large, superficial, snow-white, amorphous lumps of lime; stem about equalling the sporangium, from dirty grey to brown, dilated downwards, and passing into a dark hypothallus, longitudinally striate; capillitium colourless, forming an irregular net, threads very thin, often flexuons, nodes small, often flattened, only very few containing lime; spores globose, minutely wavted, $9-10 \mu$ diameter.

Plısarum granulatum, Balf., Grev., vol. x., p. 116; Sacc., Syll., n. 1204.

\section{(Type in Herb., Kew.)}

On wood. In Herb. Currey, Kew. No locality, but undoubtedly British.

About $1.5 \mathrm{~mm}$. high, closely resembling Physarnm leucophacum in the capillitium and spores, but distinguished by the large granules of bicarbonate of lime on the sporangial wall. In the eapillitium the present species approaches the genus Tilmadoche, but differs in the great amount of lime on the sporangium wall.

Physarum Phillipsii, Balf. fil. (figs. 77, 78). P.compressum Alb?

Sporangia stipitate or subsessile, laterally commessed, irregular, subreniform, subpyriform, sometimes coalescing, dark grey, generally more or less rugose, with numerous minute, white, innate particles of lime; stem much shorter than sporangiun, thick, often flattened, blackish, sometimes almost obsolete; columella absent; capillitium well developed, white, linots of lime large, irvegular, numerous, connected by short, thin portions; spores lilac, globose, minutely warted, 10-12 $\mu$ diameter.

Physarum Phillipsii, Balf. fil., Grev., vol. x., p. 116; Sacc., Syll., n. 1208.

\section{(Type in Herb., Kew.)}

On manured ground in an orchard house. Shrewsbury.

A very marked species, possibly having its nearest ally in Physarum nephroideum, Rost. (I. B. B.).

Mr. A. Lister has appended the following note to the type specimen of the present species in the Kew Herbarium:-

"Should not this be called Physarum compressum, A. and S., 
as the older name? I have grown it from plasmodium in large quantity, and have sporangia answering both descriptions."

The description of Physarum comprcssum, by Albertini and Schweinitz, is as follows:- " $P$. comprcssum. Stipitate, peridium umbilicate, compressed like a bivalve shell, obversely parabolic, grey. Stem of medium length, firm, brown. Peridium convex above, dehiscing by a longitudinal fissure. Threads of capillitium rather abundant, white." Alb. and Schw., Com. Fung., p. 97.

I am convinced that the present species is Physarum Phillipsii, Balf. fil., the type specimen is in a good state of preservation, and the detailed description given by the author will enable any one to recognize the species. In reply to Mr. Lister's question as to whether it is not the $P$. compressum of A. and S., I must admit that I am not at all certain; the stem is not brown as it should be, according to the description by the lastnamed authors; the white capillitium, without further qualification, is common to scores of species, therefore the only feature which remains is the compressed sporangium, and this I cannot admit as sufficient proof that Physarum Phillipsii should be reduced to a synonym of Physarum compressum, A. and S. If Mr. Lister's reasoning is sound, then we must admit that pocket-lens characters are all-sufficient for the determination of species, and that the more laborious and exact system of microscopic examination initiated by Dr. Rostafinski is a mere farce, and altogether unnecessary. In writing the above I have assumed that Dr. Lister is not in possession of the type specimen of Physarum compressum, A. and S.

Physarum didermoides, Rost. (figs. 82-84).

Sporangia elliptic-oblong, stipitate or rarely sessile, springing from a broad, membranaceous, whitish hypothallus, wall double, outer chalk-white, brittle, soon falling away; inner membranaceous, grey; capillitium with numerous, rather large nodes containing colourless granules of lime; spores globose, brownishviolet, minutely wartcd, the warts often arranged in lines; $12-15 \mu$ diameter. 
Physamun didermoides, Rost., Mon., p. 97, figs. 74, 87; Cooke, Brit. Myx., p. 11, figs. 74, 87 ; Sacc., Syll., n. 1171; Raunk., Myx. Dan., p. 72.

Didymium congestum, B. and Br., Ann. Nat. Hist. (1850), p. 365 ; Cooke, Hdbk., n. 1130.

Spumaria licheniformis, Sz. (specimen from Schweinitz in Herb. Berk.).

Exsicc.-Sacc., Myc. Ven., 269 (as Didymium congestum, B. and Br.).

On grass, twigs, bark, \&e. Britain (King's Cliffe, Bulmer, Yorks.; Carlisle); France; Germany; Italy; Russia ; Sweden ; United States; Ceylon.

Usually crowded or gregarious in considerable numbers, springing from a tough, common hypothallus; sporangia $1.5-2$ mm. long, stem variable in length, usually shorter than sporangium, generally very weak, flattened or twisted. When sessile the sporangia are sometimes shorter than usual.

\section{(Rostafinski’s Synonyms.)}

Spumaria didermoides, Ach.; in Pers., Syn., p. xxix (1801).

Diderna oblongum, Schum., Saell., n. 1423 (1803); Flor.

Dan., t. 1973, f. 1; Fr., S. M., iii., 103.

Claustria dider'moides, Fr., S. V. S., 451 (1849).

Didymium congestum, B. and Br., Ann. Nat. Hist. (1850), p. 365 ; Cooke, Hdbk., n. 1130.

Didymium farinaceum, Purt., M. F., p. 273.

Physarum imitans, Racib. Rnutans var leucophaevm.

Sporangia hemispherical, umbilicate, greyish-white, dehiscing irregularly, stipitate, erect or slightly nodding, stem subulate, brownish-black, slightly longer than the sporangium, rigid; columella absent, capillitium white, copious, forming an irregular net, nodes irregular, sometimes filled with lime; spores $9 \cdot 5-10$ mm. diam., violet, warted.

Racib., Myx. Crac., p. 5, f, 3, a, b; Sacc., Syll., 1205.

On branches. Poland. Sporangia (stem included) up to 1 mm. high. 
Physarum pulcherrimum, $B$. and $R$.

Sporangia globose or broadly elliptical, sometimes slightly umbilicate below, stipitate, varying in colour from clear deep rose-rcd to pink; stem similarly coloured, varying length from once to twice the length of the sporangium, slender, expanding at the base into a circular hypothallus, filled with particles of lime, longitudinally wrinkled; columella absent; capillitium variable, sometimes scanty, at others rather copious, threads thin, forming an irregular network, colourless, or tinged pink, swollen portions elliptical, small, number variable, interstitial, rarely produced at the nodes, containing pink granules of lime; spores globose, reddish-lilac, very minutely verruculose, $8-10 \mu$ diameter.

Physurum pulcherrimum, B. and Rav., Grev., vol. ii., p. 65, fig. 84; Cke., Brit. Myx., fig. 84; Sacc., Syll., vii., 1, n. 1178; Rost., Mon. Append., p. 8.

(Type in Herb. Berk., Kew, n. 10,781.)

On wood, \&c. United States; Paraguay.

A slender, delicate species, stem thin, erect; sporangium covered with a smooth crust composed of minute granules of lime. The hypothallus is usually pale ochraceous and wrinkled. Gregarious, sometimes becoming crowded, rarely $2-3$ sporangia supported on a common stem, from $1.5-2 \mathrm{~mm}$. high.

\section{* Epispore smooth.}

Physarum Carlylei, Mass. (figs. 240, 241). P. psittacinum,

Sporangia stipitate, broadly pyriform, orange-vermilion, minutely furfuraceous; stem about equal in length to diameter of sporangium, thick, rugulose, vermilion, expanding downwards into a small wrinkled hypothallus; threads of capillitium thin, yellow, forming a dense net, swollen at the angles and there containing orange-coloured granules of lime; columella absent; spores globose, smooth, dirty violet, $7-8 \mu$ diameter.

Grev., vol, xvii., March (1889).

On rotten wood. Carlisle. (Dr. Carlyle.) 
A very distinct species, sporangia $1.5-2 \mathrm{~mm}$. high, scattered singly or in groups of two or three. Most nearly related to Physarum ribiginosum, Fr., but readily distinguished by the smaller spores, and the scattered stipitate sporangia. Readily distinguished from the red form of Physarum Schumacheri, by the absence of a columella and the pyriform sporangium passing insensibly into the short stem.

\section{Physarum atrorubrum, Peck. P.pulcherrimum Berk. $\rightarrow$ R}

Scattered or gregarious, stipitate; sporangia globose, even or somewhat wrinkled, dark-red; stem cylindrical, even, blackish or subconcolorous, capillitium when cleared of the spores whitish, sometimes with a slight pinkish tinge; columella none; spores globose, smooth, dark-brown in the mass, dark-red when separated, $\cdot 0003-00035^{\prime}$ in diameter ( = about $8-9 \mu$ ).

I'hysanum atronubum, Peck, 31st Report, N. York State Mus., p. 40 ; Sacc., Syll., vii., 1, n. 1202 (as Physavum atromuripurcum by mistake).

Decaying wood. Adirondack Mts., U. States.

The plants are scarcely one line high. The capillitium is very delicate, and when cleared of the spores the knot-like thickenings are seen to be very small and of a dark-red colour, to which probably is due the pinkish tinge sometimes observed. 'The dark-red granules of the sporangium walls are abundant, and appear to form a continuous crust. (Peck.)

Physarum roseum, B. and $\mathrm{Br}$.

Sporangia stipitate, globose, broadly elliptical or obovate, dark recldish-purple, sporangial wall covered with a thin crust of minute granules of lime; stem brownish-purple, equal, longitudinally wrinkled, filled with granules of lime, equal to or usually longer than sporangium, expanding at the base into a small, circular, pale brown, wrinkled hypothallus; capillitium well developed, threads thin, tinged pink, with scattered, clliptical, intcrstitial sucllings containing lime, nodes not uspally enlarged or containing granules; spores globose, smooth, 10-11 $\mu$ diameter. 
Physarun roseum, Berk. and Broome, Fungi of Ceylon, ii., n. 760, in Journ. Linn. Soc., vol. xiv., p. 84; Rost., Mon. Append., p. 10; Sacc., Syll., vii., 1, n. 1194.

(Type in Herb. Berk., Kew.)

On grass, moss, bark, \&c. Ceylon; Paraguay.

Gregarious, $2 \cdot 5-3 \mathrm{~mm}$. high. Closely allied to Physarum pulcherrimum, of which the present species may eventually prove to be only a variety. The spores are generally smooth under a $\frac{1}{12}$ th objective, but some show a minutely verruculose surface.

Physarum ornatum, Peck. Pa.ayriscalpium Cooke.

Sporangia depressed or hemispherical, plane or slightly concave beneath, greenish-einereous, dotted with small yellow granules, the empty walls whitish; stem short, black or blackishbrown, generally longitudinally wrinkled when dry; columella none; capillitium with numerous, yellow, knot-like thickenings; spores globose, smooth, violet-brown in the mass, $\cdot 0004-\cdot 0005^{\prime}$ in diameter ( = about 10-11 $\mu$ ).

Physarum ornatum, Peck, 31st Report of N. York State Mus., p. 40 ; Sacc., Syll., vii., 1, n. 1220.

Decaying wood. Albany, U. S.

Physarum Petersii, B. and C. P.pulchripes Peck.

Gregarious, stipitate, sporangia globose, wall thin, yellow, with a thin sprinkling of minute particles of lime that soon disappears; stem elongated, slender, subequal or slightly thicker below, expanded at the base into a small, orbicular hypothallus, reddish-brown, longitudinally wrinkled and filled with lime; columella subglobose or shortly cylindrical, whitish; capillitium rather dense, forming an irregular network, threads thin, with scattered, elliptical, interstitial swellings containing yellow granules of lime, nodes rarely swollen; spores dirty lilac, smooth, $7-8 \mu$ diameter.

Physarum Petersii, B. and C., Grev., vol. ii., p. 66 ; Rost., Mon., p. 116, Append., p. 6 ; Sacc., Syll., vii., 1, 1174. 


\section{(Type in Herb. Berk.)}

Physarum galbcum, Wingate, in E. and E., N. Amer. Fung., 2491.

On moss, wood, \&c. U. States.

Resembling in the long, slender stem, and small, elliptical lumps of lime, some species of Tilmadoche from which genus it differs in the presence of a columella. About $2 \mathrm{~mm}$. high.

\section{Physarum hians, Mass. Physarella oblonga Mory}

Sporangia stipitate, yellowish-red, then blackish, globose or slightly elongated; stem reddish-brown, sulcate, expanding at the base into a small, circular hypothallus, penetrating the sporangium as a columella which reaches nearly to the apex; threads of capillitium yellowish, with violet tinge, forming a somewhat dense network, nodes irregularly oblong, reddishyellow, spores violet, smooth, 8-10 $\mu$ diameter.

Tijmadoche hians, Rost., Mon. App., p. 14.

Tilmadoche minuta, Berl., Sacc., Syll., vii., 1, n. 1251.

On dead leaves. Belgium.

The present species is removed from Tilmadoche on account of the columella.

Plysarnm mefibasis, B. and Br., quoted by Rostafinski as a synonym under the present species is quite distinct, hence the Ceylon habitat of the latter is incorrect.

\section{(Rostafinski's Synonyms.) .}

Cratcrizem minutum, Kickx, non Fr.

Physarmem rnfibasis, B. and Br., Fung. Ceylon, n. 762 (1873).

Chondriodermu inflatum, Rost., Mon., p. 42.5, n. 177 (1874).

See Kickx's description of Cratcrium minutum under Craterium.

Physarum Leveillei, Rost. P.ciTrinum Schumacher

Sporangia lenticular, furfuraceous, goldcn, as is also the upwards attenuated stem, threads of capillitium vanishing; spores globose, smooth, 10-11 $\mu$ dianneter. 
Physarum Leveillei, Rost., Mon. App., p. 7; Sacc., Syll., vii., 1, n. 1177.

On dead leaves. Chili.

Var. chrysopus, Rost., stem and sporangium golden-yellow, $1 \mathrm{~mm}$. diameter; spores $10 \mu$ diameter, lime granules goldenyellow.

Var. auripes, Rost.; stem golden, sporangium citrin.

Venezuela.

Var. Fuistingii, stem orange, sporangium rufous-brown.

Westphalia.

(Rostafinski's Synonym.) :

Physarum aureum, $\beta$. chrysopus, Lév., Ann. Sc. Nat., p. 116 (1846).

Physarum Kalchbrenneri, Mass. (n. sp.). P. melleum Mass.

Scattered, stipitate, sporangia spherico-depressed, umbilicate below, pale yellow-green, rough with minute particles of lime; stem elongated, thickest below or fusiform, pale pink, rigid, filled with granules of lime; capillitium forming a very dense, irregular network, nodes numerous, large, irregularly angular, containing yellow granules of lime, internodes $6-9 \mu$ thick, colourless, without lime, collapsing; spores dingy-lilac, smooth, $11-13 \mu$ diameter.

(Type in Herb., Kew, along with Tilmadoche variabilis.)

On wood. Cape of Good Hope.

Superficially resembling a typical Tilmadoche in the long, slender stem, but separated from that genus by the very thick capillitium tubes, and the numerous large, irregularly angular nodes. From $25-3 \mathrm{~mm}$. high.

Physarum globuliferum, Rost.

Sporangia globose, stipitate, greyish; stem equal to sporangium or twice as long, rigid, fragile, white, sulcate; columella large, cylindrical, obtuse, white; capillitium well developed, rigid, not collapsing, vesicles containing line numerous, of variable size, yellowish or reddish; spores globose, smooth, 9-11 $\mu$ diameter. 
Plysarum globuliferum, Rost., Mon., p. 98 ; Sacc., Syll., vii., 1, n. 1173.

On moss, leaves, rotten wood, \&c. Sweden; France; Germany.

\section{(Rostafinski's Synonyms.)}

Sphaerocarpus globulifer, Bull., Champ., p. 134, t. 484, f. 3 (1791).

Stemonitis globulifer'a, Gmel., Syst. Nat., ii., p. 1467, n. 2 (1791).

Physarum globuliferum, Pers., Syn., p. 175, t. 3, f. 11, 12 (1801).

Trichia globulifera, D.C., Fl. Fr., 2, p. 253 (1805).

Diderma globuliferum, Fr., l.c., iii., p. 100 (1829).

B. Sporangia sessile, plasmodiocarp, or acthalioid.

* Epispore warted.

Physarum cinereum, Rost. (figs. 71-73).

Sporangia sessile on a broad base, sometimes globose, scattered or crowded, at others elongated, flexuous and depressed, wall rigid with lime, white; columella absent; capillitium abundant with numerous large, irregular knots of lime connected by very thin threads; spores globose, dingy violet, minutely warted, $10-13 \mu$ diameter.

Physarum cincreum, Rost., Mon., p. 102, figs. 71, 72, 85; Cooke, Myx. Brit., p. 13, figs. 71, 72, 85 ; Sacc., Syll., n. 1189 ; Schroeter, p. 128; Raunk., Myx. Dan, p. 75, t. 4, f. 9.

Exsicc.-Ellis and Everhart, N. Amer. Fung., ser. II., n. 2085 ; Rav., Fung. Car., 79 and 83.

Fung. Cub. Wrightiani, 535; De Thum., Myc. Univ., 1598; Holl, Schmidt and Kunze, Deutsch. Schw., 38; Roum., Fung. Gall., 1881.

On leaves, wood, twigs, \&c. Britain (King's Cliffe, Bury St. Edmund's, Bungay, Kew, Hitchin, Carlisle, Scarboro', Berwick, N. Wales, Linlithgow); Germany; Finland; Sweden; Belgium; 
France; Switzerland; Algiers; S. Africa; United States; Ceylon; Australia; India.

Varying from '5-2-3 $\mathrm{mm}$. when elongated; some forms of the present species resemble externally Didymium serpula, Fr., but are readily distinguished under the microscope.

Var. ovoideum, Sacc. Sporangia vertically ovoid, densely gregarious.

Physarum cinereum, var. ovoideum, Sacc., Mich., ii., p. 334.

Britain (Lyndhurst, New Forest); France.

\section{(Rostafinski's Synonyms.).}

Mucilago crustacea, Mich., Gen., t. 96, f. 9 (1729).

Lycoperdon cincreum, Batsch, fig. 169 (1783).

Lycoperdon alni, Bjer., in Vet. Handl., p. 39 (1789).

Trichic caerulea, Trent., p. 229 (1797).

Physarum cinereum, Pers., Syn., p. 170 (1801); Nees, f. 107 ;

Letell., t. 710, f. 2.

Physarum violaceum, Schum., Saell., 1428 (1803); Fl. Dan., t. 1980 , f. 2.

Physarum corrugatum, Link, Herb.

Physarum coelatum, Ehr., Herb.

Physarum conglobatum, Fr. Gast., p. 21 (1818); Letell., t. 710, f. 3 .

Didymium cinereum, Fr., S. M., iii., 126 (1829); Eng. Fl., v., p. 314; Cke., Hdbk., 1133.

Physarum plumbeum, Fr., S. M., iii., 142 (1829).

Physarum Weinmanni, Fr., var. in litt.

Didymium melanopus, Wallr., n. 2193 (1833).

Physarum sinuosum, Wallr.

Didymium scrobiculatum, Berk., Hook. Journ. (1845), p. 66.

Physarum album, Fuckel, F. Rhèn., 1469 (1865).

Var. flexuosum, sessile on a broad base, depressed, spherical. in outline, or elongated and variously curved, wall at first white, becoming grey when the outer chalky layer has broken away in flakes; columella absent; capillitium dense, threads thin, $2 \mu$ diameter, colourless, flcxuous or spirally coilcd, furnished 
with numerons small, discoid, colourcd projections irregularly scattered, combined to form an irregular network, interstitial, small, elliptical swellings containing colourless granules of lime, very rare; spores brown with lilac tinge, globose, coarsely wartcd, $14 \mu$ diameter.

Physarum cincreum, Sacc., Myc. Ven., Exs., n. 1101.

On living or dead leaves, twigs, \&c. Britain (Epping Forest); Italy.

The above, if in reality a variety of Plysarnum cincreum, differs considerably in the structure of the capillitim and the large, coarsely warted spores. Its occurrence in Britain and Italy suggests it to be a constant form.

Physarum chrysotrichum, B. and C. P.lateritium Morq

Sporangia sessile, subglobose when scattered, often irregular or crowded and more or less confluent, wall rigid, usually granulated with projecting lumps of lime, varying from yellow through fulvous to almost clear vermilion; capillitium dense, nodes uumerous, large, irregularly angular, filled with yellow or tawny lumps of lime, connected at various points by long, thin, empty internodes, some of the nodes are small and without lime; spores lilac, globose, minutely warted, $7-8 \mu$ diameter.

Physarum chrysotrichum, B. and C., Grev., vol. ii., p. 66.

(Type in Herb. Berk., Kew, n. 10,804.)

1'hysanum inacqualis, Peck, 31st Report, p. 40.

Badhamia decipiens, Rost., Mon. App., p. 4.

"Physurnm subglobosum, (B. and C.)." Sacc., Syll., vii., 1, n. 1226. (I am not aware that there is any such species by B. and C., and it is obviously a slip in Saccardo's Sylloge for P. chrysotrichum.

On moss, wood, \&c. United States.

The type specimen is a true Physarum, as will be seen by the above description, and on the same piece of moss-covered wood ranges through the colours given above.

Physarum scrobiculatum, Mass. P.einerium Pers.

Sporangria sessile on a broad or narrowed base, seatcd on a 
thick, vide-spreading hypothallus, scattered or aggregated, often irregular and aethalioid, or several blending together to form a plasmodiocarp, pale flesh-colour, brittle, often furfuraceous; capillitium dense, forming an irregular network, nodes numerous, large, irregularly angular, filled with yellow granules of lime, connected at several points by long, thin, colourless internodes without lime; columella absent; spores lilac-brown, globose, minutely warted, 13-14 $\mu$ diameter.

Didymium scrobiculatım, Berk., Hook. Journ., vol. iv., p. 66.

Physarum cinereum, Sacc., Syll., vii., 1, n. 1189 (in part.).

(Type in Herb. Berk., n. 10,77:4.)

On charred wood. Australia.

Distinct from $P$. cinereum in the size of the spores, widespreading, firm hypothallus, and colour of the sporangial wall.

Physarum Rostafinskii, Mass. P. conglomeratum Rost.

Sporangia distinct, conglomerated, sessile, rounded or angular, depressed, exterior membrane thickish, granular, chalky, fragile, yellow or ochraceous, interior wall thin, grey or yellowish, from $0 \cdot 2-0.5 \mathrm{~mm}$. diameter; capillitium furnished with numerous irregularly angular nodes containing coloured granules of lime; columella cylindrical, spores minutely spinulose, blackish-violet, 8-9 $\mu$ diameter.

Physarum conglomeratum, Rost., Mon., p. 109; Sacc., Syll., vii., 1, n. 1184.

On leaves, moss, \&c. Germany; Sweden; Finland; San Francisco.

I am not acquainted with the present species, which is certainly not Diderma conglomeratum, Fr., as supposed by Rostafinski, hence the localities given by Rostafinski may or may not show the distribution of this species; the same applies to his synonyms.

(Rostafinski's Synonyms.)

Diderma ochraceum, Hoffm., Fl. Germ., iii., t. 9, f. 2, b (1795). Reticularia ochracea, Poir., Ency. ap Streintz (1795). 
Spumaria granularia, Schum., Fl. Saell., n. 1419 ; Fl. Dan., t. 1979 , f. 2 (1803).

Spumaria minuta, Schum., Fl. Saell., n. 1419; Fl. Dan., t. 1979 , f. 1 (1803).

Diderma vitellinum, Link, Herb.

Didymium glomeratum, Fr., Herb.

Didymium contextum, $\beta$. glomerulosum, Fr., Sym. Gast., p. 20 (1818).

Diderma conglomeratum, Fr., l.c., iii., p. 111 (1829).

Diderma granulatum, Fr., l.c., iii., p. 110 (1821).

Diderma minutum, Fr., l.c., iii., p. 111 (1829).

Diderma rugulosum, Wein., l.c., p. 594 (1836).

Diderma flavum, Fr., in Wein., l.c., p. 593 (1836).

Leocarpus minutus, Fr., Sm. Veg. Scan., p. 540 (1849).

Leocarpus granulatus, Fr., Sm. Veg. Scan., p. 541 (1849).

Carecrina conglomerata, Fr., Sm. Veg. Scan., p, 451 (1849).

Physarum rubiginosum, Rost. I r

Sporangia gregarious, usually nearly globose, attaclied by a broad or narrow base, wall double, outer layer brittle, breaking away in flakes, from dirty orange to elear vermilion, inner wall very thin, grey; columella absent; capillitium copious, nodes and interstitial swollen portions numerous, variable in size, containing yellow or reddish granules of lime; spores dingy violet, $10-13 \mu$ diameter, with a slight indication of boing verruculose.

Physarum rubiginosum, Rost., Mon., p. 104; Sacc., Syll., vii., 1, n. 1180.

On moss, \&c. Sweden; Finland; United States.

Sessile, globose, $1-1.5 \mathrm{~mm}$. diameter; distinguished by the bright colour of the outer layer of the sporangial wall, the very thin, grey, inner layer, absence of columella and spores which vary from being perfectly smooth to very minutely verruculose. The granules of lime present on the outer wall of the sporangium, when examined under the microscope, are seen to be mostly minute and yellow, amongst which are a few seattered, larger ruby-red lumps. 
(Rostafinski's Synonyms.)

Physarum rubiginosum, Fr., Sym. Gast., p. 21. non Chev. (1818).

Leangium rubiginosum, Fr., Stirp. Femsj., p. 83 (1825).

Physarum fulvum, Fr., l.c., iii., p. 143 (1829).

Physarum contextum, Rost. (figs. 276-283). Pers

Sporangia sessile on a broad base, crowded, subglobose, reniform, or elongated and variously interlocked, wall double, outer thick, containing lime, varying from colourless to deep lemonyellow, inner thin, yellowish; capillitium well developed, with numerous, irregularly branched nodes containing lime, usually tinged yellow; spores globose, brownish-violet, minutely warted, 11-14 $\mu$ diameter. .

Physarum contextum, Rost., Mon., p. 109 ; Cooke, Brit. Myx., p. 13; Raunk., Myx. Dan., p. 73; Sacc., Syll., n. 1185; Schroeter, 130.

Exsicc.-Fckl., Fung. Rhen., 2400 (as Diderma contextum, Pers.); Ellis and Everh., N. Amer. Fung., ser. II., 2086.

On moss, leaves, and bark. Britain (Shere, Kew, King's Cliffe); France; Germany; United States; Ceylon.

In some of its forms resembling Physarum conglomeratum, from which it is known by the denser capillitium of numerous large, irregular knots containing yellow granules of lime, and the larger sporangia usually of a pale lemon-yellow, sometimes with a very faint tinge of green.

(Rostafinski's Synonyms.)

Diderma contextum, Pers., Obs., i., 89 (1796); Ditm., t. 39; Cke., Hdbk., n. 1117.

Physarum contextum, Pers., Syn., 168 (1801).

Didymium contextum, Fr., Gast., p. 20 (1818).

Lcocarpus contextus, Fr., S. V. S., 4500 (1849).

Chondrioderma contextum, Rost., in Fckl., Sym. Myc., ii., 74 (1873).

Diderma ochroleucum, B. and C., Grev., 343. 
Physarum diderma, Rost. P.didermoides var. lividum.

Sporangia sessile, adnate by a narrow base, globose, snow-whitc, wall double, outer dense, fragile, thick, charged with lime, inner thin, separated for some distance from the outer, the obsolete columella composed of numerous angularly-globose granules of lime; spores dingy violet, spinulose, $9-10 \mu$ diameter.

Physarum Diderma, Rost., Mon., p. 110; Sacc., Syll., vii., 9, n. 1168 .

Poland.

The above imperfect description suggests the geuus Chondrioderma rather than Physarum.

Physarum lividum, Rost. P.dider movdes Rost

Sporangia crowded, sessile, subglobose or irregular, blackish, thickly covered with small white particles of lime; columella absent; spores globose or subangular, opaque, ininutely aspernlose, $10-12 \mu$ diameter; capillitium almost absent.

Physarum lividum, Rost., Mon., p. 95 ; Sacc., Syll., vii., 1, 1169.

On fallen Opuntia. Sweden; Germany; Algeria; N. America.

I have no knowledge of the present species, which appears to be too briefly described to insure future identification.

(Rostafinski's Synonyms.)

Plyssarum griseum, Link, Diss. II., f. 42 (1809).

1'hysarum effusum, Link, Herb. (1809).

1'hysamu conglobatum, Fr., Sym. Gast., p. 21, p.p. non Dit. (1818).

Spumaria licheniformis, Sz., Amer. Fung., n. 2364 (1834).

Didymium physaroides, M. Fl. Alg., p. 412, non Fr. (1846).

Licea alba, Boug., Herb. (1846).

Physarum conglomeratum, Mass. (figs. 210-212, 284-286).

Sporangia sessile on a broad base, convex above, crowded, subangular from mutual pressure, wall double, outer containing 
much lime, rough, dirty ochraceous, breaking away irregularly, inner membranaceous, grey; columella absent; mass of spores blackish-violet; capillitium rather dense, flaccid, threads colourless, $2 \cdot 5-3 \mu$ thick, irregularly anastomosing, nodes distant, irregularly globose, filled with colourless granules of lime; spores globose, dusky violet, coarsely warted, $11-13 \mu$ diameter.

Diderma conglomeratum, Fries, Syst. Myc., iii., p. 111 (not Physarum conglomeratum of Rost., Mon., f. 90 ; Cke., Brit. Myx., f. 90 ; Sacc., Syll., v., 7, n. 1184):

(Specimen from Fries in Herb. Berk., Kew.)

On bark. Britain (King's Cliffe); Sweden.:

Sporangia about $\bullet \check{\mathrm{m} m}$. diameter. Capillitium consisting of long, thin, anastomosing internodes, nodes distant, subglobose, without tapering rays, but giving origin at once to the thin, empty, flaccid internodes.

The above description is compiled from a specimen sent by Fries to Berkeley, and marked in Fries' handwriting, "Diderma conglomeratum, Fries, Suec. Lindberg." The specimen is now in the Berkeley collection in the Kew Herbarium. From the above it will be seen that Rostafinski's Physarum conglomeratum, which he considers to be the Diderma conglomeratum of Fries, is not that species at all, hence synonyms have not been given. I am not acquainted with a species corresponding to Rostafinski's description.

Physarum sinuosum, Rost. (figs. 292, 293). Weinm,

Plasmodiocarp laterally compressed, elongated, flexuous, or irregularly anastomosing, white or yellowish, usually dehiscing by a split along the upper, free margin, wall double, the outer mostly converted into lime, brittle, the inner without lime, grey; capillitium dense, knots containing lime large, numerous, connected by short, thin portions; spores globose, brownishviolet, variously but always very minutely verruculose, 8-9 $\mu$ diameter.

Physarum sinuosum, Rost., Mon., p. 112, f. 91 ; Cooke, Brit. Myx., p. 14, f. 91 ; Sacc., Syll., n. 1198 (Excl. Syn. Diderma pallidum, B. and C.). 
Exsicc.-Karst., Fung. Fenn., 698; Lib., Crypt. Ard., 376; Fckl., F. Rhen., 1466 ; Cke., Brit. Fung., Ed. II., 206 ; Ellis, N. Amer. Fung., 1394; Klotzsch, Herb. Myc. (Rab.), 761; Syd., Myc. March., 257; Rab., F. Eur., 798, 1913, 1070, 2139.

On bark, wood, \&c. Britain (Bristol, Hampstead, Castle Howard, Yorks; Carlisle, Linlithgow); France; Germany; Finland; Austria; United States; Cuba; Ceylon.

Readily distinguished by the very much laterally compressed plasmodiocarp. The outer wall is sometimes almost as porcelain-like as in Chondriodcrma, but is usually rugulose. The epispore varies, when seen under a power of 1200 diameters, from almost smooth to being distinctly warted, and in some instances the warts become bar-like and more or less combined to form a very delicate and broken network.

\section{(Rostafinski's Synonyms.)}

Téticularia sinuosa, Bull., t. 446, f. 3 (1791); Sow., t. 6. Plhysarum bivalve, Pers., Obs., t. 1, f. 2 (1796).

Trichia sphacrica, $\beta$. polymorpha, Trent., p. 230 (1797).

Angioridium sinuosum, Grev., S. C. Fl., t. 310 (1828); Eng.

Fl., v., 315; Cooke, Hdbk., n. 1142, fig. 128.

Diderma valvatum, Fr., S. M., iii., 109 (1829).

Didymium sinuosum, DR. and M., Fl. Alg., p. 411 (1846).

Carecrina valvata, Fr., S. V. S., p. 451 (1849).

Lcocarpus melalcucus, Gay, in Mont. Syll., 1072 (1855).

Diderma contortum, Fckl., Sym. Mrc., 341 (1869).

Diderma pallidun, B. and C., in Grevillea, iii., 59 (1873).

Physarum cerebrinum, Mass. (n. sp.) (fig. 275). Fuligo septica $9_{m}$

Aethalium naked, broadly effused, or in small scattered patches, consisting of very much contorted and anastomosing folds, greyish-lilac, sprinkled with minute particles of lime; capillitium consisting of numerous, irregularly anastomosing threads about $3 \mu$ thick, with here and there usually interstitial, large, elongatcd swellings filled with large, amorphous, ycllow granules of 
lime; spores globose, dull violet, very minutely verruculose, 9-11 $\mu$ diameter.

On wood and soil in a pot of palm-seeds from Java. Palm House, Kew.

Contorted and forming a brain-like mass from $5 \bar{b}-4 \mathrm{~cm}$. across, very friable. The present species connects the genera Physarum and Fuligo, if indeed the letter be anything more than an aethalioid condition of the former.

\section{Physarum gyrosum, Rost.}

Sporangia vermiform, sinuous, or variously anastomosing to form an irregular network, often forming more or less regular closed circles, wall double, outer very thin and delicate, inner thicker, rigid with granules of lime, varying from rusty-orange, through dull ochre to pale yellow, dehiscing in an irregular manner, capillitium fairly abundant, nodes large, angular, containing yellow or white granules of lime, internodes thin ; spores dingy violet, $11-12 \mu$ diameter, minutely warted, globose.

Physarum gyrosum, Rost., Mon., p. 111.

Physarum muscorum, Sacc., Syll., vii., 1, 1197. ,

Exsicc.-EEllis, N. Amer. Fung., 1396.

On leaves, mosses, \&c. Britain (Carlisle); Germany; Sweden; France; Portugal ; United States.

Variable in size, the large reticulations often extending up to $1 \mathrm{~cm}$. diameter. Superficially closely resembling Ceinkowskia reticulata.

\section{(Rostafinski's Synonyms.)}

Fuligo muscorum, A. and Sz., l.c., p. 86, t. 7, f. 1 (1805).

Lignidium griseo-flavum, Link; Obș., i., p. 24, t. 2, f. 37; Nees, Syst., f. 95 (1809).

Lignidium muscicola, Fr., Sym. Gast., p. 10 (1817).

Lignidium reniforme, Fr., Sym. Gast., f. 10 (1817).

Reticularia muscorum, Fr., l.c., iii., p. 91 (1829).

Physarum sinuosum, Wein., in Fr., 1.c., iii., p. 145; Excl. sinom. Non. Auc. (1829). 
* Epispore reticulated.

Physarum concinnum, Mass. (figs. 22-24). Badhamia lilacina

Gregarious or crowded, sessile on a broad or narrowed base, globose, outer wall white, thick, at first crust-like or continuous, pulverulent, falling away in flakes and exposing the inner, thin, iridescent wall; columella absent; capillitium dense, knots large, irregularly stellate, white, connected by short, thin internodes; spores globose, dingy purple, with slightly raised ridges of various lengths anastomosing to form an irregular network, $11-13 \mu$ diameter.

Diderma concinnum, B. and C., Grev., 1873, n. 343.

Chondrioderma floriforme, Sacc., Syll., n. 1285 (in part.).

On moss and wood. Britain (King's Cliffe); United States.

Sporangia about $\cdot 5 \mathrm{~mm}$. diameter; the outer chalky layer is at first compact and somewhat resembles that characteristic of the genus Chondrioderma, but differs in being minutely pulvèrulent and not porcelain-like. The British specimen differs from the type in the Berkeley collection at Kew in having the ridges on the epispore more decided, and forming a more distinct reticulation. In the type the epispore is furnished with a mixture of warts and bars, but the warts are usually arranged in anastomosing lines. Saccardo's synonym is clearly due, to some mixture of specimens, not, however, present in the type specimen.

\section{*** Epispore smooth.}

Physarum Braunianum, De Bary. P.lateritium Morq

Sporangia irregularly globose, minute, sessile, scattered or collected in little clusters, brown; columella absent; capillitium well developed, knots of lime small, brown, angularly globose; spores violet, smooth, 10-11 $\mu$ diameter.

Physarum Braunianum, De Bary, MS.; Rost., Mon., p. 105; Sacc., Syll., vii., 1, 1182.

Germany.

About $55 \mathrm{~mm}$. diameter. 


\section{Physarum Famintzini, Rost. ?}

Sporangia sessile, minute, crowded, sometimes ' confluent, dingy chestnut, irregularly hemispherical, dehiscing at the apex; columella absent; capillitiium elastic, becoming elongated after dehiscence, nodes not usually developed, sometimes containing pale pinkish granules of lime; spores pale violet, smooth, $10 \mu$ diameter.

Physarum Famintzini, Rost., Mon., p. 107 ; Sacc., Syll., vii., 1, n. 1181.

On branches. Poland.

I don't know the present species, which, judging from Rostafinski's description, must be a very peculiar and far from typical species of Physarum.

\section{Physarum capense, Rost. P. cinereum Pers}

Sporangia irregularly hemispherical or turbinate, sessile; simple, or most frequently in crowded clusters springing from a well developed hypothallus, greyish-white; columella absent; capillitium copious, nodes of lime few, subglobose with angular projections, internodes very long; spores pale violet, smooth, 11-14 $\mu$ diameter.

Physarum Capense, Rost., Mon., p. 113, f. 92; Cke., Brit. Myx., f. 92 ; Sacc., Syll., vii., 1, n. 1190.

On branches. Cape of Good Hope.

Physarum luteolum, Peck. P.virescens vav,nitens Lister

Sporangium small, closely gregarious, sessile, yellowish, inclining to tawny, rupturing irregularly; flocci abundant, yellowish-white; spores globose, purplish-brown, $\cdot 0004$ ' in diameter ( = about $10-11 \mu$ ).

Physarum luteolum, Peck, 30th Report of N. York State Mus., p. 50, pl. ii., figs. 15-18; Sacc., Syll., vii., 1, n. 1199.

Living leaves of Cormus Canadensis. Adirondack Mts., U. States. 
**** Spores elliptical.

Physarum ellipsosporum, Rost. (fig. 214). Fuliqo cinevea Morq

Plasmodiocarp variable in form, vermiform, sinuous, or reticulately combincd, depressed, wall firm, charged with particles of lime, whitish or grey; capillitium well developed, nodes numerous, containing colourless granules of lime, internodes long, slender ; spores dirty lilac, broadly elliptical, warted, many of the warts becoming clongated and ridge-like, 12-16+9-11 $\mu$.

Physarum ellipsosporım, Rost., Mon. App., p. 10 ; Sace., Syll., vii., 1, n. 1191.

Entcrilium cincroum, Schweinitz, Amer. Fung., n. 2365.

(The specimen from Schweinitz in Herb. Berk., Kew, is the one examined by Rostafinski.)

On decaying herbs. Carolina.

\section{(Rostafinski's Synonym.)}

Enteridium cincrcum, Schweinitz, Amer. Fung., n. 2365 (1834).

C. Position uncertain, owing to imperfect description and alsence of specimens.

\section{Physarum flavo-virens, A. and S. ?}

Sporangia obovate, greenish-yellow; stem brownish; spores black.

Physarum. flavo-virens, Alb. and Schwz., Nisk., p. 97; Fr., Syst. Myc., iii., p. 137 ; Sacc., Syll., vii., 1, n. 1216.

Amongst moss on rotten trunk.

Stem of medium length; sporangium piriform, fragile, smooth, not squamulose. (A. and S.)

\section{Physarum luteo-valve, Sz.?}

Irregularly lobed, convex, more or less confluent; sporangia externally shiming, gold-colour, more or less compressed like a kivalve shell; spores deep yellow. 
Physarum lutco-valve, Schweinitz, Syn., Fung. Amer. Borealis, n. 2298; Sacc., Syll., vii., 1, n. 1218.

On fallen twigs. Carolina.

\section{Physarum sulphureum, Rost.}

Sporangia spherical, rugoso-squamulose, sulphur-coloured; stem smooth, short, white, tapering from the incrassated base in an exactly conical manner, about equal in length to the sporangium or slightly longer; capillitium threads yellow; spores blackishviolet, $10-12 \mu$ diameter.

Physarum sulphureum, Rost., Mon., p. 101; Sacc., Syll., vii., 1, n. 1187.

On dry fallen leaves. Germany; Russia.

\section{(Rostafinski's Synonyms.)}

Physarum sulphureum, A. et Sz., 1.c., n. 259, t. 6, f. 1 (1805).

Physarum virescens, Fuckel, Syst. Myc., p. 343; non Ditm. (1869).

Physarum Schweinitzii, Berk. Oliqonema nitens Rost

Gregarious, shining, yellow; the few capillitium threads and globose granulated spores the same colour, about $16 \mu$ diameter, sometimes rather irregular.

Physarum Schweinitzii, Berk., Grev., vol. ii., p. 66 ; Sacc., Syll., vii., 1, n. 1225.

Polyangium vitellinum, Schweinitz (according to Berkeley).

On vegetable fragments. Bethlehem, U. S. (Schweinitz.)

Berkeley has probably at some time had a specimen from Schweinitz's Herbarium, but no such specimen exists in Berkeley's Herbarium, consequently I am not able to determine the nature of the specimen those authors had in view.

Physarum caespitosum, Sz. P. ciTrinellum Peck.

Substipitate or at least contracted at the base, caespitose or scattered; sporangia close packed, turbinate, obovate, base contracted, exterior membrane with yellow squamules or rough 
with particles; spores blackish-brown, threads of capillitium citrin.

Physarum caespitosim, Schweinitz, Syn., Fung. Amer. Bar., n. 2310 ; Sacc., Syll., vii., 1, n. 1212.

On leaves and stems of Rhododendron. Bethlehem; United States.

\section{Physarum muscicolum, Pers.?}

Sporangia turbinate, grey; stem short, yellowish; capillitium white; spores black.

Physanum muscicolum, Pers., Obs., i., p. 6 ; Pers., Syn., p. 176 ; Alb. and Schw., p. 93 ; Sacc., Syll., vii., 1, n. 1219.

On the larger mosses in pine woods, peat mosses, \&c. Sweden; Germany.

Scattered or gregarious, hypothallus not distinct; stem variable in length, about twice as long as sporangium, often reddish; sporangium smooth, at length squamulose, varying from obovate to cylindrical; threads adnate, white, spores compacted. (Pers.)

Physarum albicans, Peck. P. qlobuliferum Pers

Sporangia whitish, fugacions, except at the base, externally mealy with lime granules, globose, as well as the more persistent whitish capillitium; stem white, tapering upwards, sometimes connate at the base, slightly penetrating; spores globose, purplish-brown, $\cdot 00033^{\prime}$ in diameter ( $=$ about $8-9 \mu$ ).

Pliysarum albicans, Yeck, 30th Report, State Mus. of N. York, p. 50, pl. ii., figs. 5-8; Sacc., Syll., vii., 1, n. 1201.

Didymiun sulroscum, Peck.

Bark and mosses. Adirondack MIts., U. States.

The fragments of the base of the peridium sometimes remain just below the capillitium, surrounding the stem like a calyx or collar. The stem is even and generally longer than the peridium, which it penetrates. After the spores have fallen the whitish colour of the capillitium becomes apparent. It then resembles a sinall globose tuft of wool. The plants grew on the branches and mosses of a standing dead birch tree. 
Didymium subroseum is apparently the same species, with a pinkish tinge to the peridium. (Peck.)

\section{Physarum effusum, Schw. Morq.}

Broadly effused or vermiform, sinuous, and combined to form a reticulation, whitish, almost membranaceous, very much flattened; threads of capillitium and mass of spores blackish.

Physarum effusum, Schweinitz, Syn., Fung. Amer., Bar., n. 2297 ; Sacc., Syll., vii., 1 n. 1211.

Broadly effused on ashes or soot (" pulvere vaporario"). Salem; United States.

\section{Physarum elegans, Sz. ?}

Sporangia crowded, subrotund, difformed, convex, flattened above, subrugose, clear amethyst-colour; spores blackish-brown; threads of capillitium thickish.

Physarum elegans, Schweinitz, Syn., Fung. Amer., Bar., n. 2294; Sacc., Syll., vii., 1, n. 1213.

Salem; United States.

\section{Physarum piceum, Fr. ?}

Scattered; sporangia sessile, globose, pitch-black, shining; capillitium threads very slender, and with the spores, smokyblack.

Physarum piccum, Fr., Syst. Myc., iii., p. 143 ; Sacc., Syll., vii., 1, n. 1222.

On heaped up decorticated oak branches. Sweden.

Sporangial wall very thin, membranaceous, very smooth, but rugulose, dehiscing irregularly, the size of a turnip-seed; capillitium threads very slender, almost inconspicuous. (Fries.)

\section{Physarum antiades, Fries. Diderma Horitorme Pers.}

Sporangia globose, smoky-brown, marked with sinuous lines; stem branched, blackish, sulcate; threads and spores brown.

Physarum antiades, Fr., Syst. Myc., iii., p. 135 ; Sacc., Syll., vii., 1, n. 1209. 
Sphaerocarpus antiades, Bull., Champ., p. 127, t. 368.

Trichia antiades, D.C., Fl. Fr., 2, p. 252 ; Chev., Par., p. 325.

On rotten wood. France.

Stem thick, deformed, several confluent, branched, irregularly lacunose; hypothallus membranaceous, whitish; sporangia dehiscing by irregular rupture towards the apex from which the capillitium protrudes. (Fr.)

Judging from Bulliard's figure, and also from some points in the description, the present species is much more likely to be a Cribraria than a Physarum.

Physarum reticulatum, Berl. P.atrum Schwein

Sessile, oblong or subdeformed, aggregated, externally black or greyish; sporangia smoothish but elegantly reticulated; spores black; threads of capillitium whitish, rare.

Physarım reticulatım, Berlese, Sacc., Syll., vii., 1, n. 1210.

Physarum atrum, Schweinitz, Syn., Fung. Amer., Bor., n. 2297.

On bark. Bethlehem; United States.

Allied to Physarum cinercum, but larger. (Sz.)

Schweinitz's specific name was antedated by Persoon.

\section{Physarum fimetarium, Schum.?}

Sporangia obovate, pale purple-umber; stem short, subflexuose; capillitium and spores brown.

Physamum fimetarium, Schum., Saell., ii., p. 205 ; Fr., Syst. Myc., iii., p. 138; Sacc., Syll., vii., 1, n. 1214.

On cow-dung. Scandinavia.

Scattered; at first semi-liquid and white, then yellowish, piriform, substipitate, at length purple-umber; sporangia becoming torn at the apex; stem subflexuous, slightly thickened upwards. (Schum.)

Physarum hypnophilum, Fr.

Subsessile; sporangia rounded, smooth, bay-coloured; the very delicate threads and spores black. 
Physanum hypnophilum, Fries, Stirpes Femsj., p. 83 ; Sacc., Syll., vii., 1, n. 1217.

On Hypnum cupressiforme, growing on damp rocks. Sweden.

Scattered or gregarious, hypothallus not persistent; stem either absent or very short, rather thick, subdecumbent, coloured like the sporangium, which is very delicate, subglobose or attenuated at the base, the size of a turnip-seed, bay, rather shining, dehiscing by the irregularly torn apex; rugulose when old, but not hyaline, threads very slender, black, adnate to the wall of the sporangium. (Fries.)

There is a specimen of Lamproderma physiaroides, sessile or nearly so, marked "Physarum hypnophilum,". by Fries, and judging from the above description, Fries had probably had a Lamproderma in view; the bay colour is rather against this idea, unless the coppery tint often present on the wall was intended.

\section{Physarum atrum, Fries.}

Closely aggregated, confluent, black; sporangia very thin, rounded; capillitium threads none; spores black.

Physarum atrum, Fr., Syst. Myc., iii., p. 147 (not of Schweinitz); Sacc., Syll., vii., 1, n. 1221.

Lycogala atra, Pers.

On dead trunks.

Sporangia adnate by a broad, flat base, rounded, connate from the centre downwards, often densely crowded and forming a continuous patch $2 \mathrm{~mm}$. broad; dehiscing irregularly, spores very abundant. (Fries.).

Rostafinski says (Mon., p. 302), that the present species is not a Myxogaster but an Apiosporium, probably A. imersum, but he had not examined an authentic specimen from Fries, and as Fries' description of the present species does not agree at all with the genus Apiosporium, it appears at best doubtful as to whether this synonymy is correct.

Physarum pulcherripes, Peck.

Peridium globose, variable in colour, ochraceous, grey, brown, 
or black; stem slender, equal, or slightly tapering upward, vermilion; spores globose, brown, $\cdot 00033$ in. in diameter ( = about $9 \mu$ ).

Physarum pulcherripes, Peck, 26th Report, New York State Mus., p. 75 ; Sacc., Syll., vii., 1, n. 1207 (as P. pulchripes).

Rotten wood. Richmondville and Worcester.

The bright colour of the stem is quite conspicuous, notwithstanding the sinall size of the plant.

\section{Physarum polyaedron, $\mathrm{Sz}$. ?}

Gregarious or slightly scattered; sporangia rather large, smoky-black, dull, subhemispherical, exactly pentagonal, sides plane, rugulose, dehiscing in an irregularly stellate manner, lower portion persistent; spores smoky-black, mixed with threads of a similar colour.

Physarum polyaedron, Schweinitz, N. Amer. Fung., n. 2300, p. 257 ; Sacc., Syll., vii., 1, 1224.

On very old walnut trunk. Bethlehem; United States.

Schweinitz says the present species resembles some minute sea-anemone.

\section{Badhamia, Berk. (emended).}

Sporangia stipitate or sessile, wall single, dehiscing by the irregular rupture of the upper portion; threads of the capillitium springing from all parts of the sporangial wall, combined to form an irregular network, usually thick, and containing granules of lime throughout their length; columella absent; spores originating in clusters or free from the first, globose or elliptical.

Badhamia, Berk., Linn. Trans., xxi., p. 153; Berk., Outl., p. 303; Cooke, Hdbk., p. 391 ; Cooke, Myx. Brit., p. 25 ; Rost., MIon., p. 139 ; Sacc., Syll., vii., p. 329 ; Zopf, p. 147.

The genus, as founded by Berkeley, was characterized by the clustered spores, a feature now well known to be far from constant, even in the same species; Berkeley further considered that the clusters of spores originated in hyaline cysts or mothercells; this has not been corroborated. The genera included in 
the Physarae are very closely allied, in fact so much so, that only the most typical species can be recognized from the features usually considered characteristic of each, numerous transitional species connecting the genera at various points. The most pronounced character of Badhamia, as defined above, is the thick capillitium threads which contain lime in the form of small granules throughout their entire length, and not concentrated in large nodes separated by thinner portions without lime, as in the genus Physarum. Very closely allied to Craterium. For distinguishing features see note following last-named genus.

Distrib. Europe; N. Americạ. Species, 18.

$\S$ Spores equally warted all over.

Badhamia macrocarpa, Rost. (figs. 79-81 and 294-297).

- Sporangia gregarious or scattered, stipitate or sessile, springing from a slender hypothallus, subglobose, grey, base dirty brownish-yellow, this colour usually continuing upwards in a veinlike manner, upper part of sporangium with vein-like patches of white lime, wall thin, stem when present variable in length, rather stout, brownish-yellow, or pale, rugnlose; capillitium dense, knots numerous with scattered granules of lime; spores free, globose, equally warted all over, the warts sometimes show a tendency to become elongated, brownish-purple, 10-15 $\mu$ diameter.

Badhamia macrocarpa, Rost., Mon., p. 143, figs. 118, 120, 121 ; Cooke, Brit. Myx., figs. 118, 120, 121; Sacc., Syll., n. 1144.

Physarum macrocarpon,' Ces., in Rab. Fung. Eur., n. 1968; Flora, 1855, p. 271.

Exsicc.-Rab. Fung. Eur., n. 1968; Syd. Myc. March., n. 1600 (stipitate form as Physarum leucophaeum).

On decaying fungi, bark, \&c. Britain (Lyndhurst, East Bergholt, Glamis, Aboyne, N. B., Kensington Gardens); France; Germany; Italy; Poland.

Plasmodium yellow. Sporangia up to $1.5 \mathrm{~mm}$. diameter, either crowded and sessile on a broad base, or with a stem equal to or longer than the sporangium. The yellowish colour at 
base of sporangium shows inside when the spores are blown away. For distinguishing characters from $B$. panicea, see under that species.

(Rostafinski's Synonym.)

Physarum macrocarpon, Caes., Rab. Fung. Eur., n. 1968; Cfr. Flora, 1885, p. 271 (1855).

Badhamia panicea, Rost. (figs. 74-76).

Sporangia gregarious on a thin hypothallus, sessile on a broad or narrow base, globose or irregularly angular from mutual pressure, wall thin, often iridescent, studded all over with innate, detached, irregular patches of lime, the whole with a grey tint; capillitium very dense, snow-white, knots large, branched, connected by thick bands, evcry part densely filled with granules of lime; spores free, or with an indication of being originally in clusters, globose, very minutely verruculose, dull violet, or brownish-purple, $9-12 \mu$ diameter.

Badhamia panicea, Rost., Mou., p. 144, f. 114 and 116; Cooke, Myx. Brit., f. 114 and 116 : Sacc., Syll., n. 1141.

Physarum paniceum, Fr., S. M., iii., p. 141.

Exsicc.-Fckl., Fung. Rhen., 2499 (as Didymium cinercum); Desm., Cr. Fr., 272.

On leaves, twigs, bark, Sc. Britain (Hitchin, Blackheath, Dunton Green, Bungay, Kew); France; Germany; Sweden.

Plasmodium white. Sporangia up to $1 \mathrm{~mm}$. diameter, generally crowded and forming dense pale grey patches. Closely resembling superficially Badhamia macrocarpa, but distinguished by the coarser capillitium having every part crowded with lime, the much smaller warts on the epispore, and the absence of rugulose veins on the sporangial wall.

\section{(Rostafinski's Synonyms.)}

Mucilago, n. 8, Mich., Nov. Gen., p. 216, t. 96, f. 8 (?) (1729). Physarum paniceum, Fr., 1.c., 141 (1829).

Reticularia Schintzii, Debey, 1.c., p. 1, t. 2, f. 1-3 (1847). 


\section{Badhamia varia, Mass.}

Sporangia more or less aggregated, sessile or stipitate, globose or obovate, grey and opaque, or shining with metallic tints; stem when present generally weak and decumbent, several often more or less grown together, pale yellow or reddish, springing from a well developed hypothallus of the same colour; capillitium variable, well developed, krots large or not very evident; spores in clusters or free from the first, globose, minutely warted all over, dingy lilac-brown, $9-12 \mu$ diameter.

Badhamia hyalina, Berk., Linn. Trans., xxi., t, 19, f. 3 ; Rost., Mon., p. 140, fig. 113; Cooke, Myx. Brit., p. 25, f. 113; Sacc., Syll., vii., n. 1150.

Exsicc.-Roum., Fung. Gall., 43; Fuckel, Fung. Rhen., 2689.

Badhamia capsulifera, Berk., Linn. Trans., xxi., p. 153; Rost., Mon., p. 141 ; Cooke, Myx. Brit., p. 26 ; Sacc., Syll., vii., n. 1151.

Badhamia utricularis, Berk., Linn. Trans., xxi., p. 153; Sacc., Syll, vii., n. 1149.

Badhamia magna, Peck, and Dictydium magnum, Peck, 31st Report, N. Y. Mus., p. 56.

On wood, moss, \&c. Britain (Batheaston, Kew, East Bergholt, Scarboro', Carlisle, Glamis, N. B.) ; France; Germany ; Sweden; Belgium; Italy; United States; Ceylon; W. Australia; Tasmania.

The examination of a large series of the three species given as synonyms above, shows' every shade of transition from one to another. When sessile the sporangia are globose or irregular from mutual pressure; when stipitate, usually more or less obovate or irregular. The amount of lime present on the wall varies considerably; when abundant, the surface is usually grey and opaque; when scanty, iridescert. The clustered stems are usually very slender and decumbent, and the clusters of sporangia are sometimes pendulous. The capillitium is snow-white. The distinctive features of the species as defined above are the globose spores warted all over, and the smooth wall of the 
sporangium, not rugulose as in $B$. macrocarpa, or with white, superficial patches of lime as in B. panicea.

(Rostafinski’s Synonyms.)

(Badhaniia hyalina.)

Physarum hyalinum, Pers., Disp., t. 2, f. 4, (1797); Eng. Flor., v., p. 315; Ann. Nat. Hist., n. 213.

Physanum membranaceum, Schum., Herb.

Physarum globuliferum, DC., in Herb.

Physamum hyalinum, a. albidum, A. and S., 256 (1805).

Physarum cinereum, Link, Diss., i., 27 (1809).

Physarum botryoides, a.hyalinum, Fr., Stirp., p. 83 (1825).

Physarum botrytis, Somm. (1826).

Physarum gracile, Weinm., Herb.

Physarum cancellatum, Wallr., Fl. Germ., 2128 (1833).

Diderma papaverinum, Wallr., Fl. Germ., 2210 (1833).

Badhamia hyalina, Berk., Linn. Trans., xxi., t. 19, f. 3 (1851),

Cooke, Hdbk., n. 1143.

Physarum gracilentum, Fckl., Sym., 342 (1869), non Fries.

(Badhamia capsulifcra.)

Sphacrocarpus capsulifer, Bull, t, 470, f. 2 (1791).

Trichice capillifera, DC., Fl. Fr., 684 (1805).

Physarum capsuliferum, Chev., Fl. Fr., i., 339 (1826).

Laulhamice capsuliferum, Berk., Linn. Trans., xxi., p. 153

(1851); B. and Br., Ann. Nat. Hist., n. 1595 ; Grevillea, vol. v., p. 12 (not Cooke).

(Badhamia utricularis.)

Sphaerocarpus utvicularis, Bull, t. 417, f. 1 (1791).

Physarum ovoideum, Schum., Saell., 1425 (1803).

Trichic utricularis, DC., Fl. Fr., 676 (1805).

Physarum hyalinum, $\beta$. chalybeum, A. and S., n. 256 (1805).

Physamu botryoides, $\beta$. chalybeus, Fr., Stirp., p. 83 (1825).

Physarum utriculare, Chev., Fl. Par., i., 337 (1826); Berk.,

Ann. Nat. Hist., 214.

Physamum caemelesccns, Pers. in Litt.

Physamum alutaceum, Wallr., Herb. 


\section{Badhamia.}

Budhamia utricularis, Berk., Linn. Trans., xxi., p. 153 (1801); Cooke, Hdbk., n. 1147.

Physarum melaleucum, Nyl., p. 126 (1859).

Badhamia granulifera, Phill. Lepidoderma Carestianum

Gregarious, but not crowded, sessile on a broad base, hemispherical or slightly elongated, subdepressed, wall thick, with crowded, large, flattencd, glistening, pale brown scales of bicarbonate of lime; inner wall very thin, iridescent; splitting irregularly above; mass of spores blackish-purple; columella shortly cylindrical or subglobose; capillitiam copious, forming an irregular network, passing from the columella to the inner wall, threads with numerous, irregular flattened inflations containing minute granules of lime; spores at first in clusters; spherical when free, with a small circular portion of the wall thinner and convex, minutely warted all over, 18-20 $\mu$ diameter.

Badhamia granulifera, Phillips, in Herb.

Didymium granuliferum, Phill., Grev., vol. v., p. 114, t. 88, f. 1, $a-f$; 'Sacc., Syll., vii., 1, n. 1316.

\section{(Type in Herb., Phill.)}

On herbaceous stems. San Francisco.

A very beautiful and remarkable species, externally resembling a Lepidoderma in the large, distinct, scale-like patches of bicarbonate of lime. Sporangia circular or elongated, slightly depressed, 2-3 $\mathrm{mm}$. long.

Badhamia Fuckeliana, Rost. Trichamphora pezizordea Jung

Sporangia discoid, $1 \mathrm{~mm}$. broad, stipitate, frequently umbilicate above or below; stem even, elongated, coloured; spores blackish-violet; epispore dclicatcly spinulose, $9-12 \mu$ diameter.

a. genuina. Sporangia $1 \mathrm{~mm}$. diameter, stem $1 \mathrm{~mm}$. long.

$\beta$. gracilis. Sporangia $5 \mathrm{~mm}$. diameter, stem $1-1.5 \mathrm{~mm}$. long.

Badhamia Fuckeliana, Rost., Mon. App., p. 2; Sacc., Syll., vii., 1, n. 1148.

Trichamphora Fuckcliana, Rost., Mon., p. 138. 
On wood and decaying Auricularia. Germany; France; Sweden.

\section{(Rostafinski's Synonyms.)}

Physarım macrocarpum, Fckl., Sym. Myc., p. 343, non Cesati (1869).

Trichamphora Fuckelianum, Rost., in Fckl., S. M., 2, Nach., p. 74 (1873).

A specimen named by Rostafinski in Herb., Berk. has the superficial appearance of a Tilmadoche; a slender, elongated, wrinkled, bright brown stem, and grey sporangial wall.

Badhamia nodulosa, Mass. Physurum pusillum hil

Sporangia globose, stipitate, wall very thin, almost colourless above, and covered with an irregular white crust of lime, basal portion without lime and beautifully iridescent; becoming irregularly ruptured at maturity; stem longer than sporangium, weak, often subdecumbent, attenuated upwards, bronvn, longitudinally wrinkled, expanding at the base iuto a small, irregular hypothallus; columella absent; capillitium well developed, flattened, intricately branching from the nodes, scantily furnishcd throughout with granules of lime; spores globose, dingy lilac, minutcly vervuculose, $10-12 \mu$ diameter.

Badhamia nodulosa, Mass., Journ. Myc., vol. v., p. 186, t. 14, f. 6 .

Physam nodulosum, Cooke and Balf., in Rav., Fung. Amer., Exs., n. 479 .

On acacia bark. Aiken, S. Carolina (Rav., 2972).

$$
\text { (Type in Herb., Kew.) }
$$

A very distinct and good species of the genus Badhamia, $1.5 \mathrm{~mm}$. high; stem twice as long as sporangium, weak, usually subprostrate; capillitium dense, with the characteristic flattenings met with in Badhamia, and everywhere containing granules of lime, although the quantity is not so great as is usual. Sparsely scattered, rarely two springing from the same hypotliallus. 
Badhamia irregularis, C. and E.

Scattered, sessile; sporangia suborbicular or confluent, at length blackish-brown; spores brown, globose, aspcrulate, $10 \mu$ diameter.

Badhamia irregularis, Cooke and Ellis.

On pine wood. N. America.

I have seen no specimen of the present imperfectly described species.

$\S \S$ Spores in cluster's, free, surface warted, remainder smooth.

Badhamia papaveracea, Berk. and Rav.

Sporangia usually densely gregarious, with a few scattered marginal individuals, hemispherical or irregularly polygonal from mutual pressure, sessile, or with a rudimentary stem, wall smooth or rugulose, white, greyish, or yellowish, iridescent when empty; capillitium usually dense, white, threads with large nodular or interstitial swellings containing lime, combined to form an irregular network; mass of spores blackish-purple, spores at first in cluster's of 3-7, triangularly pyramidal, with a rounded base which corresponds to the free portion of the spore, and is covered with minute warts, the remainder smooth, pale lilac or brownish-lilac, 9-10 $\mu$ diameter.

Badhamia papaveracca, Berk. and Rav., Grev., vol. ii., p. 66 (1873); Rost., Mon., p. 147; Sacc., Syll., vii., 1, n. 1152.

(Type in Herb. Berk., Kew, n. 10794.)

Badhamia pallida, Berk., Linn. Trans., xxi., p. 153, t. 19, f. 2 ; Sacc., Syll., n. 1153 (in part.).

(Type in Herb. Berk., 10790.)

Exsicc.-Ellis, N. Amer. Fung., 1214 (as Badhamia hyalina, p. 320).

On wood, \&c. Britain (East Bergholt, Weybridge); U. States.

Allied to B. nitens, which differs in the bright yellow sporangial wall, and the much more coarsely warted free portion of the spores. 
Badhamia nitens, Berk. (figs. 176-179).

Sporangia globose, sessile, aggregated, bright yellow, covered with minute, scale-like particles of lime; splitting irregularly above; capillitium well developed, threads thick, yellowish, lime almost obsolete; spores purple, aggregated in clusters, free portion coarsely warted, remainder smooth, $10-16 \mu$ diameter.

Badhamia nitens, Berk., Trans. Linn. Soc., xxi., p. 153, t. 19, f. 1 ; Rost., Mon. App., p. 27 (in part.).

\section{(Type in Herb. Berk.)}

Badhamia inaurata, Currey, Linn. Trans., xxiv. (1851), t. 25, f. 8; Cooke, Myx. Brit., p. 28 ; Sacc., Syll., vii., n. 1162.

(Type in Brit. Mus.)

On moss, wood, \&c. Britain (Carlisle, East Bergholt, Weybridge).

Readily distinguished by the bright yellow sporangia and the clustered spores.

\section{$\S \S \S$ Spores smooth.}

\section{Badhamia Alexandrowiczii, Rost.}

Sporangia gregarions but distant, irregular, sutrotund or reniform, about $0.7 \mathrm{~mm}$. broad, $0.7-2 \mathrm{~mm}$. long, bright yellow-brown or pallid; capillitium well developed, tubes thick, nodes $35 \mu$ broad; spores 9-11 $\mu$ diameter, obscure violet, smooth.

Badhamia Alexandrowicaii, Rost., Mon., p. 146; Sacc., Syll., vii., 1, n. 1154 .

On dead leaves. Poland; Germany.

Sporangial wall thick, rufous-brown, dehiscing in a circumscissile manner by an opcrculum. (Berlese in Sacc., Syll.)

\section{(Rostafinski's Synonym.)}

Physamom Alexandroviczii, De Bary and Rost., in Litt., Ad. Alexand., l.c., p. 88 (1872).

\section{Badhamia verna, Rost.}

Sporangia gregarious, depressed, variable in form, confluent, not sinuous, wall very thin, blackish-brown, smooth, very fragile, 
becoming lacerated during dehiscence, at length evanescent; threads of capillitium adnate, vague, white; spores blackistibrown, 12-13 $\mu$ diameter, smooth.

Badhamia verna, Rost., Mon., p. 145; Sacc., Syll., vii., 1, n. 331.

\section{(Rostafinski's Synonym.)}

Physarum vernum, Somf., in Litt., Ad. Fries, S. M., iii., p. 146 (1829).

\section{Badhamia microcarpa, Schroeter.}

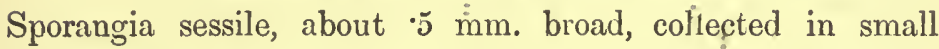
clusters or arranged in rows; hypothallus nearly obsolete; sporangial wall thin, bright grey; capillitium slender, white, threads irregularly nodulose with masses of lime, from 3-4 up to $12 \mu$ thick, nodes not incrassated; spores not clustered, 7·5-9 $\mu$ diameter, smooth, violet.

Badhamia microcarpa, Schroeter, Kr. Fl. Schles., p. 131 ; Sacc., Syll., n. 1145.

\section{Badhamia melanospora, Speg.}

Sporangia sessile, densely gregarious, spherical, smooth, greyishwhite, after the spores have disappeared, snow-white; columella absent; tubes of capillitium rigid, united to form a compact network, internodes fusiformly thickened in the centre, nodes flattened; spores in clusters or free, smooth, black, opaque, subangular from mutual pressure, $15 \mu$ diameter.

Badhamia melanosperma, 'Speg., Fung. Arg., Pug. I., p. 88; Sacc., Syll., n. 1164.

On rotten trunks. Argentina.

\section{Badhamia coadnata, Rost.}

Sporangia very numerous, conglomerated; sporangia springing from a white, well-developed hypothallus; capillitium threads snow-white, copious, rigid, aggregated in the centre towards the base of the sporangium to form an irregular columella; spores globose, bright violet, epispore thick, smooth, $8-9 \mu$ diameter. 
Badhamia coadnata, Rost., Mon., p. 146; Sacc., Syll., vii., 1, 11. 1142 .

\section{(Rostafinski's Synonym.)}

Didymium crustaccum, M.

\section{Badhamia fasciculata, Rost. ?}

Sporangia globose, white, dehiscing irregularly, upper portion disappearing, lower portion persistent, irregularly cupulate with a torn margin; stems fasciculate, caespitoso-connate, 3-6 or more, connected at the base, erect, tough, dirty yellowish, shining, attenuated upwards, subsulcate, base thickened, blackish; spores violet, $11-12 \mu$ diameter, smooth.

Badhamia fasciculata, Rost., Mon., p. 146; Sacc., Syll., vii., 1, n. 1143.

On trunks of Pandanus. Java.

(Rostafinski's Synonym.)

Physarum fasciculatum, Jungh., Fl. Crypt, Java, p. 14, t. 11, f. 8 (1838).

Badhamia ovispora, Racib.

Sporangia sessile, globoso-depressed, $0.5-0.75 \mathrm{~mm}$. broad, membrane calcarcous, scabrid, fragile, base yellow, apex discoloured; capillitium with abundance of lime, white, rigid, nodes large, irregular; columella absent; spores violet, cllipsoid, smooth, 14-16 × 7-8 $\mu$.

Bulhamia orispora, Racib., Myx. Crac., p. 4, f. 2, $a, b$; Sacc., Syll., 1165.

On poplar branches. Poland.

\section{$\S \S \S$ Position uncertcin.}

Badhamia fulvella, Berk. B.nitens Berk.

Sporangia gregarious, but not forming distinct patehes, sessile, globose, blackish, invested with a delicate tawny pubescence, when the spores are expelled, yellowish; capillitium not coloured, 
tubes swollen; spores dark violet, agglutinated in clusters, $.0125-018 \mathrm{~mm}$.

Badhamia fulvella, Berk., Trans. Linn. Soc., xxi., p. 154; Cooke, Myx. Brit., p. 27 ; Sacc., Syll., vii., 1, n. 1166.

On dead wood. Britain (East Bergholt, Suffolk).

I have seen no specimen of the present, hence cannot add to Berkeley's description.

\section{Tilmadoche, Rost.}

Sporangia stipitate, wall thin, single, with a thin deposit of lime in the form of minute, irregular lumps, either continuous or most frequently in patches, dehiscing in an irregularly reticulate manner; stem elongated, slender, filled with irregular particles of lime, becoming longitudinally wrinkled when dry; columella absent; capillitium well developed, threads slender, attached to the wall at various points, combined to form an irregular network, nodes small, scattered, mostly elliptical, filled with granules of lime.

Tilmadoche, Rost., Mon., p. 126; Cooke, Myx. Brit., p. 21; Sacc., Syll., vii., 1, p. 359 ; Zopf, p. 148.

The present genus is characterized amongst its allies by the thin sporangial wall furnished with a scanty deposit of lime in the form of minute, amorphous granules, the slender threads of the capillitium with small, sparingly scattered elliptical nodes containing lime, and the elongated, slender stem filled with lumps of lime. Closely allied to the genus Physarum, with which it is connected by a form of Tilmadoche nutans, having the capillitium threads stouter, and the nodes larger and more numerous than usual. Another form of the same species having the capillitium very slender and without nodes connects with the Hemididymium section of Didymium.

Tilmadoche nutans, Rost. (figs. 19-21).

Sporangia spherico-depressed, more or less umbilicate below, wall thin, greyish or white, with a thin layer of minute, amorphous lumps of lime, becoming irregularly cracked; stem slender, 
clongatcd, becoming thinner upwards, usually slightly curverl at the apex, filled with irregular masses of lime, trownish below, rale uproards, expanding into a small hypothallus; capillitium well developed, threads thin, combined to form a very irregular network, furnished with scattcred, small, elliptical nodes containing granulcs of lime; spores globose, pale lilac, smooth, or very minutely verruculose, $9-11 \mu$ diameter.

Tilmadoche nutans, Rost., Mon., p. 127, f. 129 ; Cooke, Myx. Brit., p. 21, f. 129 ; Sacc., Syll., vii., 1, n. 1244; Raunk., p. 76, t. 4 , f. $10-11$.

Exsicc.-Rab., Fung. Eur., 40 (the specimen shows a transition to Physarum (eucophacum); Sacc., Myc. Fenn., 1102; Syd., Myc. March., 491; Fuckel, Fung. Rhen., 1456 and 1457; Jack, Leiner u. Sitzenb., 423.

On wood, bark, dead leaves, \&c. Britain (Bournemouth, New Forest, Kew, Chester, Scarboro', Carlisle, Inverness, N.B.); Europe; N. Africa; United States; Ceylon; Australia; India.

From $1.5-2.5 \mathrm{~mm}$. high, gregarious, stem slender, usually slightly bent at the apex, consequently the sporangium is more or less clrooping.

\section{(Rostafinski's Synonyms.)}

Sphucrocarpus allus, Bull., t. 407, f. 3, $c-y$ (1791).

Stcmonitis alba, Gmel. Sys., 1469 (17!1).

Mucor albus, Sobolen. Petr., 324 (1779).

Physarum nutans, Pers., Syn., p. 171 (1801; Berk., Eng. Fl., v., 314; Cooke, Hubk., n. 1135 (partly).

Plıysarum subtilc, Pers., Syn., p. 171 (1801).

Trichia cemuru, Schum., Saell., 1410 (1803).

Physarum bulbiforme, Schum., Saell., 1432 (1803); Fl. Dan., t. 1974, f. 3.

Physarum marginatum, Schum., Saell., 1440 (1803).

Physanum didymium, Schum., Saell., 1441 (1803).

Physarum albopunctatum, Schum., Saell, 1433 (1803).

Physerum brevipes, Schum., Herb.

Physarum cinercum, Schum., Herb. 
Physarum leucopus, Schum., Herb.

Trichia alba, DC., Fl. Fr., ii., 202 (1805).

Physarum albipes, Link, Diss., i., 27 (1809).

Physamum sulcatum, Link, Diss., i., 27 (1809).

Physarum connectum, Ditm., t. 41 (1817).

Physarum cernuum, Fl. Dan., t. 1974, f. 2 (1823).

Physarnum nutans, a. albocincreum, Fr., S. M., iii., 128 (1829).

Didymium marginatum, Fr., S. M., iii., 116 (1829).

Tilmadoche cernua, Fr., S. V. S.; 454 (1849).

Tilmadoche mutabilis, Rost. (figs. 236-239).

Sporangia spherical or spherico-depressed, flattened cr slightly umbilicate below, wall thin, with a thin layer of yellow, dingy orange, or greenish coloured particles of lime, usually cracking in an areolate manner; stem elongated, slender, slightly thinner upwards, straight or usually a little curved at the apex, filled with granules of lime, yellow, brownish-orange, or red, darkest below; capillitium rather dense, threads slender, combined to form a very irregular network, with scattered, small, elliptical nodes containing coloured granules of lime; spores globose, pale lilac, often with a brown tinge, minutely verruculose, 9-11 $\mu$ diameter.

Tilmadoche mutabilis, Rost., Mon., p. 130, figs. 123-127, 132; Cooke, Myx. Brit., p. 22, figs. 123-127, 132; Raunk., Myx. Dan., p. 77.

Tilmadoche viridis, Sacc., Syll., vii., 1, n. 1247.

Exsicc.-Ellis, N. Amer. Fung., 1213.

On wood, bark, dead leaves, moss, \&c. . Britain (New Forest, Epping Forest, Bulmer, Yorks. ; Carlisle); Europe; S. Africa; W. Australia; United States.

Differing from Tilmadoche nutans in colour more than in any other character.

(Rostafinski's Synonyms.)

Stemonitis viridis, Gmel., Sys., ii., 1469 (1791).

Stemonitis aurantia, Gmel., Sys., ii., 1469 (1791). 
Stemonitis bicolor, Gmel., Sys., ii., 1469 (1791).

Sphaerocarpus luteus, Bull., t. 407, f. 2 (1797).

Sphaerocarpius viridis, Bull., t. 407, f. 1 (1797).

Sphaerocarpus aurantins, Bull., t. 484, f. 2 (1797).

Physarum aureum, Pers., Disp., t. 1, f. 6 (1801); Grev., t. 124; Ditm., t. 23.

Physarum viride, Pers., Syn., p. 172 (1801); Ditm., t. 24;

Nees., f. 108.

Physarum aurantium, Pers., Syn., t. 3, f. 7 (1801).

Physarum luteum, Pers., Syn., 172 (1801).

Trichia viridis, DC., Fl. Fr., ii., 252 (1805).

Trichia aurantia, DC., Fl. Fr., ii., 253 (1805).

Physarum nutans, $\beta$. viride, Fr., S. M., iii., 129 (1829); Cooke, Hdbk., n. 1135, var. B.

Physarum nutans, $\gamma$. aureum, Fr., S. M., iii., 129; Cooke, Hdbk., n. 1135, var. $\gamma$.

Physarnm nutans, $\delta$. coccineum, Fr., S. M., iii., 129.

Physarum striatum, c. aurantiacum, Fr., S. M., iii., 131.

Physarum nutans, c. luteovirens, Rabh., Fl. Cr., 2268 (1844).

Physarum viride, Fr., S. V. S., 453 (1849).

Physarum aureum, Fr., S. V. S., 453 (1849).

Physamum coccineum, Fr., S. V. S., 453 (1849).

Tilmadoche gracilenta, Rost.

Sporangia globose, slightly umbilicate below, wall blackishbrown, hoary with scattered particles of lime; stem elongated, thick at the base, which is expanded into a small hypothallus, tapering upwards and usually slightly curved, dark brown below, paler above, longitudinally wrinkled, filled with particles of lime; capillitium rather scanty, threads irregularly anastomosing, nodes scattered, small, elliptical, containing colourcd granulcs of lime; spores globose, brownish-lilac, very minutely verruculose or smooth, $8-10 \mu$ diameter.

Tilmadoche gracilenta, Rost., Mon., p. 129 ; Sacc., Syll., vii., 1, n. 1246 ; Raunk., Myx. Dan., 76.

On bark and wood. Britain (a specimen from Sowerby's Herbarium, named by Rostafinski); Europe; United States. 
Appears to be a variety of $T$. nutans, with a blackish-brown sporangial wall.

\section{(Rostafinski's Synonyms.)}

Mucor, Fl. Dan., t. 467, f. 3 (1770).

Trichia nutans, Trent., l.c., p. 227.

Physarum solutum, Schum. Fl. Saell., n. 1446; Fl. Dan., t. 1974, f. 1.

Physarum subulatum, Schum., Fl. Szell., n. 1437.

Physarum globosum, Schum., Fl. Saell., n. 1442.

Physarum furfuraceum, Schum., Fl. Saell., n. 1445.

Physarum globosum, Sommf., Fl. Lap., p. 243 (1825).

Physarum gracilentum, Fr., l.c., iii., p. 133 (1829).

Didymium furfuraceum, Fl., l.c., iii., p. 116.

Tilmadoche soluta, Fr., Sum. Veg. Scand., p. 454 (1849).

\section{Tilmadoche columbina, Rost.}

Sporangia globose, or spherico-depressed, usually more or less umbilicate below, at first pale grey or whitish, delicately frosted with minute white particles of lime, dark grey and slightly iridescent after the lime has been removed; stem 3-4 times as long as height of sporangium, snow-white, tapering upwards, straight or slightly inclined above, longitudinally wrinkled, rigid, filled with particles of lime; columella absent; capillitium well developed, threads thin, colourless, combined to form an irregular network, furnished here and there with small, elliptical, interstitial swellings containing colourless granules of lime; angles of bifurcation not swollen; spores globose, pale dingy lilac, very minutely verruculose, 10-11 $\mu$ diameter.

Tilmadoche columbina, Rost., Mon. App., p. 13 ; Sacc., Syll., vii., $1,1249$.

Didymium columbinum, B. and C., in Herb.

(Type from which Rostafinski founded the species in Herb. Berk., Kew, n. 10,767.)

Gregarious on rotten wood. Venezuela.

About $2 \mathrm{~mm}$. high. 


\section{Tilmadoche Berkeleyi, Mass.}

Sporangia globose, very slightly or not at all umbilicate below, dark blue-grey, frosted with minute particles of lime; stem blackish-brown, slender, attenuated upwards, thick at the base, and passing into a very distinct, circular, pale bronon hypothallus, longitudinally wrinkled, filled with granules of lime and masses of organic matter, usually straight; capillitium dense, threads $3-4 \mu$ thick, pale yellonvish-bronon, combined to form a very irregular network, swollen portions very rare, small, and with only a few scattered granules of lime, apparently entirely absent; spores globose, lilac-brown, very minutely warted, $11-12 \mu$ diameter.

Physamum columbinum, Fr.

A specimen so named by Berkeley, but certainly not that species.

(Type in Herb. Berk., n. 10,813.)

On twigs. New England, U. S.

Gregarious, growing often in rows, 2-2.5 $\mathrm{mm}$. high.

\section{Tilmadoche compacta, Wing.}

Sporangia brownish-white, flattened, globose, occasionally globose, nodding, borne on subulate, yellowish-white stipes, which have a brown or blackish base, and reach to a height of three or four times the width of the sporangium; sporangium wall studded with numerous, snow-white lime-granules, the remainder of the wall bronze-colour, with a metallic lustre, splitting on maturity in a floriform manner, with from six to twelve laciniae; capillitium, after removal of the spores, white, with a faint bluish tint under reflected light owing to the translucence or iridescence of its delicate threads; the latter originate from a central lime-granule which is generally quite large, branch several times as they proceed towards the surface of the sporangium, and join into a dense, compact net, the ends of the last branches attached to the inner side of the sporangium wall; lime-granules in the capillitium, very few, small, white, fusi- 
forin; spores bright brown-violet (brown in the mass), very delicately warted, 7-9 mk.

Fairmount Park, Phila., Pa. and Ohio (Morgan).

This Tilmadoche has marked characteristics. The stipe for a short distance from the base is very dark, but suddenly changes to a yellowish-white. When the sporangium bursts, the top part of the wall generally pulls out the capillitium immediately over the central lime-granule, so that the latter is exposed to view. In some: cases, when quite large, the granule falls out, leaving a circular empty space in the centre of the sporangium, without disturbing the outline of the capillitium. The capillitium is very flimsy, and its faint bluish tint in the mass quite marked under a parabolic reflector. The metallic lustre of the sporangium wall is constant in the specimens collected during different summers. (Wing.)

Tilmadoche compacta, Wingate, Acad. Nat. Sci. Phil., 1889, p. 48.

Exsicc.-Ellis, N. Amer. Fung., 2087 (as Tilmadoche colum$\operatorname{bina}, \mathrm{B}$.$) .$

Tilmadoche cavipes, Berk.

Plasmodium white, venulose, anastomosing; young sporangia flesh-colour, when older becoming sprinkled with brick-red powder, globose, stem white, thickened at the base, hollow; spores blackish-purple, globose, smooth; capillitium scanty, yellow.

Tilmadoche cavipes, Berk. Three new Indian Fungi; in Grev., vol. xi., p. 39 (1882); Sacc., Syll., vii., 1, n. 1252.

On leaves of different species of Phalaenopsis. Andaman Isles. Lieut.-Col. E. S. Berkeley, 1882.

The filmy reticulate mycelium at length disappears, and the peridia are scattered, looking at first sight from their white stems like Diachaca. The species is altogether distinct from T. lateritia, Lev. The dust of the peridia consists of irregular fragments of a bright orange-red.

Tilmadoche anomala, Mass. (n. sp.).

Gregarious; sporangia globose or slightly depressed, minutely 
umbilicate below, white, sprinkled with minute particles of lime; stem elongated, slender, equal, straight, pale yellow, longitudinally wrinkled, filled with particles of lime, expanding at the base into a minute circular hypothallus; capillitium rather dense, threads everywhere equal, about $3 \mu$ thick, combined to form a loose, irregular network, nodes very rarely slightly incrassated, and containing a few minute, colourless granules of lime; spores globose, dirty lilac, smooth, $10 \mu$ diameter.

On wood. Venezuela.

An apparently very distinct species, remarkable for the almost total absence of thickened nodes or swollen interstitial portions of the capillitium tubes, hence approaching the section Hemididymium of Didymium. From 3-3.5 mm. high.

\section{Tilmadoche oblonga, Rost.}

Scattered or gregarious, stipitate; sporangia cylindrical, obtuse at both ends, apex broadly and deeply umbilicate, tawny-olive, sprinkled with pale particles of lime; stem elongated, slender, becoming thinner upwards, straight, or usually more or less curved near the apex, reddish or yellow-brown, more or less longitudinally wrinkled, filled with minute particles of lime; capillitium well developed, threads colourless, thin, with scattered, small, interstitial, fusiform swellings containing colourless or yellowish granules of lime, angles of bifurcation not incrassated; spores dingy lilac, globose, minutcly verruculose, $7-9 \mu$ diameter.

Tilmadoche oblonga, Rost., Mon. App., p. 13 ; Sacc., Syll., vii., 1 , n. 1250 .

Trichamphora oblonga, Berk. and Curtis, Grev., vol. ii., p. 66 ; N. Amer. Fung., n. 360.

(Type specimen in Herb. Berk., Kew, n. 10,917.)

Physarclla mirabilis, Peck, Bull., Torr. Bot. Club., vol. ix., p. 61, pl. 24, figs. 1-6 (wretched figures); Rev. Myc., 1882, p. 172, tab. xxix., fig. 5 (after Peck's figures); Sacc., Syll., vii., 1, n. 1227.

Exsicc.-Ellis, N. Amer. Fung., n. 1212.

On wood, leaves, Sc. United States. 
About $2 \mathrm{~mm}$. high, stem straight or curved, thin, sporangium typically cylindric-oblong, broadly and deeply umbilicate at the apex; there is no trace of a columella. The present species appears to be inclined to sport. Mr. Harold Wingate, of Philadelphia, has sent me a fine series of forms of the present species passing from the typical form described above to specimens that are much larger, with a shorter, thicker, red stem, which is in some instances branched and bearing $3-5$ sporangia. These vary in form from the typical condition, through cyathiform to broadly funnel-shaped, with a recurved, often flexuous margin, externally reddish-brown, internally orange-yellow; in these forms the umbilicus has become so deeply depressed that the cavity of the sporangium is almost obliterated. It is the inner depressed apical portion of the sporangium that Peck describes as a spurious, hollow columella; he has obviously formed the genus Physarella from an abnormal condition of the present species.

\section{Tilmadoche gyrocephala, Rost.}

Sporangia irregularly lobed or lacunose, often compressed and umbilicate below, stipitate, wall thin, covered with irregular yellow or greenish-yellow scales of lime; stem elongated, tapering upwards, weak and often curved, irregularly rugulose, passing downwards into a thin, wrinkled hypothallus, bright yellow or orange; columella absent; capillitium well developed, forming a loose net, nodes elongated, filled with yellow granules of lime, internodes long, thin; spores globose, minutely warted, dingy, lilac, $7-9 \mu$ diameter.

Didymium gyrocephalum, Mont., Ann. Sci. Nat., Ser. II. vol. viii., p. 362 ; Mont., Syll., n. 1073.

I'ilmadoche gyrocephala (Mont.), Rost., Mon., p. 131 ; Sacc., Syll., vol. vii., pt. I., n. 1248; Mass., Journ. Myc., vol. v., p. 187, t. 14, f. 8 (1889).

Cribraria staminiformis, Speg., Fung. Arg., Pug. II., n. 109.

Exsicc.-Rav., Fung. Amer., n. 477 (as Physarum Schumacheri, Spr.). 
On twigs, moss, \&c. Brazil; Argentine Republic; Aiken, S. Carolina.

Gregarious, 1·ॅ-2 $\mathrm{mm}$. high, having the habit of Physamum Schumacheri, but readily distinguished by the absence of a columella and the very irregular sporangia which is not due to the coalescence of several individuals, as proved by the thin, simple stem.

\section{Tilmadoche reniformis, Mass. (n. sp.).}

Gregarious ; sporangia reniform, deeply umbilicate below, sometimes umbilicate above also, and then presenting a dumb-belllike form, coating of lime white, often becoming cracked, stem elongated, slender, erect, straight, tapering upwards, pale brown, wrinkled, filled with granules of lime; capillitium rather scanty, threads forming a very loose net, with scattered, fusiform swellings, colourless or tinged yellow; spores globose, dull purple, cocrsely spinulose, $16-17 \mu$ diameter.

Ceylon.

\section{(Type in Herb. Berk., Kew.)}

On bark. Gregarious, rarely scattered, $2 \mathrm{~mm}$. high. The sporangium is sausage-shaped and curved, the stem entering the concave side or umbilicus. This peculiarity, and more especially the large, coarsely spinulose spores, characterize the species.

\section{Ceinkowskia, Rost.}

Wall of sporangium single, containing lime, dehiscing irregularly; capillitium attached at many points to wall of sporangium, forming an irregular network having numerous free, curved, pointed ends.

Ceinkonstica, Rost., Mon., p. 91 ; Cooke, Brit. Myx., p. 11 ; Scluroeter, p. 131 ; Sacc., Syll., vol. vii., pt. I., p. 329.

Physarum, Alb. et Schwz., p. 90.

Diderma, Fr., S. M., iii., p. 112.

Didymium, Bischoff. Kryptogamenkunde, f. 361. 
Very closely allied to the genus Physarum, differing only in having some free ends to the network of the capillitium.

Distrib. Europe; United States. Species 1.

\section{Ceinkowskia reticulata, Rost. (figs. 266, 267).}

Plasmodiocarp elongated, sinuous or irregularly anastomosing, wall rough with lime, deep yellow, sometimes with a tinge of brown; capillitium rather scanty, threads yellow, about $3 \mu$ thick, forming an irregular net, with free, curved, pointed ends; here and there large, irregular, flattened nodes containing yellow granules of lime are present; spores globose, dull violet, very minutely verruculose, $8-10 \mu$ diameter.

Ceinkowskia reticulata, Rost., Mon., p. 91, fig. 107; Cooke, Myx. Brit., fig. 107; Schroeter, p. 131 ; Sacc., Syll., n. 1440.

On dead leaves and wood. Britain (Sibbertoft); Germany; Sweden; United States.

Usually forming an irregular network $5-2 \mathrm{~cm}$. across, dehiscing irregularly. The number of flattened, lime-containing nodes varies considerably in different individuals, being sometimes very numerous and originating mostly from the wall of the sporangium. Closely resembling in habit and general appearance Physarum gyrosum, Rost., a species not yet discovered in Britain.

(Rostafinski's Synonyms.)

Physarum reticulatum, Alb. and Sz., l.c., 251, t. 7, f. 2 (1805).

Diderma reticulatum, Fr., l.c., iii., 112 (1829).

Didymium reticulatum, Bischoff. Kryptogamenkunde, f. 361 (1842).

\section{LEOCARPUS, Rost.}

Wall of sporangium composed of two distinct layers, dehiscing in an irregular manner; capillitium attached at numerous points to wall of sporangium, threads combined to form a dense, irregular network with numerous nodes, many of which are empty, the remainder large and filled with small granules of 
lime; columella absent; spores free from the first, or originating in clusters.

Leocarpus, Rost., Mon., p. 132 ; Cooke, Myx. Brit., p. 23; Sacc., Syll., vii., 1, p. 358; Zopf, p. 148.

The one species included in the present genus is characterized by the smooth, polished sporangial wall, and by the heterogeneous structure of the capillitium, most of the swollen nodes containing air, while a few of the largest are filled with granules of lime as in the genus Physanum. Some years ago I met with a batch of Leocarpus fragilis having the spores arranged in clusters as in some species of Badhamia, and the following note by Mr. A. Lister, attached to the present species in the Kew Herbarium shows that this condition, although not constant, is not altogether abnormal, and what is of more interest, tends to show that aggregation of the spores in clusters is not of specific value. "In some sporangia the aggregation of the spores is as marked as in any Badhamia hyalina, while in others there is no such appearance at all."

Distrib. Europe; United States; Tasmania. Species 1.

Leocarpus fragilis, Rost. (figs. 187-189).

Sporangia obovate, with a more or less elongated, slender, weak stem, or sub-globose and nearly or quite sessile, vary in colour from bright chestnut to ochraceous, very smooth, shining; hypothallus well developed, capillitium dense, some of the nodes empty, others fillcd with colourcd gramules of lime; spores globose, either free from the first or in clusters, dingy purple, sometimes with a brown tinge, 11-15 $\mu$ diameter, minutely warted.

Lcocarpus fragilis, Rost., Mon., p. 132, f. 93; Cooke, Myx. Brit., p. 23, f. 93; Sacc., Syll., vii., 1, n. 1242 ; Zopf, p. 148.

Exsice.-M. A. Libert. Pl. Crypt. Ard., Fase. I., n. 76 ; Syd., Myc. March., 1297; Flor., Exs. Austro-Hung., 1854; Karst., Fung. Fenn., 377 ; Fuckel, F.ung. Rhen., 1465; Rab.-Klotzsch, Herb. Myc., 37 ; Ellis, N. Amer. Fung., 1123; Rav., Fung. Car., 78.

On twigs, grass, moss, \&c. Britain (Helstcn, Cornwall; New 
Forest, Epping, Hereford, Scarboro', Carlisle, Denbigh, Appin, N. B.); Europe; U. States; Tasmania.

Usually densely gregarious, sometimes several sporangia are more or less grown together, $2-3 \mathrm{~mm}$. high, distinguished by the pyriform or obovate, polished sporangia.

\section{(Rostafinski's Synonyms.)}

Lycoperdon fragile, Dicks. Cr., t. 3, f. 3 (1785); Sow., t. 136.

Reticularia fragilis, Poir, Ency.

Lycoperdon parasiticum, With. Arr., iv., 379 (1792).

Diderma vernicosum, Pers., Obs., t. 3, f. 7 (1796); Fl. Dan., t. 1312, f. 2 ; Eng. Fl., v., 311; Cooke, Hdbk., n. 1108.

Trichia lutea, Trent., p. 230 (1797).

Diderma vernicosum, $\beta$. parasitica, Pers., Syn., 165 (1801).

Physarum nitidum, Schum., Saell., 1451 (1803).

Physarum vernicosum, Schum.; Saell., 1452 (1803).

Lcocarpus vcrnicosus, Link, Obs., i., 25 (1809); Nees., f. 100 ;

Grev., S. C. Fl., iii.; Corda, v., f. 32.

Leocarpus spermoides, Link, Obs., i., 25 (1809).

Leocarpus atrovirens, Fr., Gast., p. 13 (1817).

Leangium vernicosum, Fr., Stirp., 83 (1825).

Diderma atrovirens, Fr., S. M., iii, 103 (1829).

Tripotrichia elegans, Corda, Ic., i., f. 288 A (1837).

\section{Fuligo, Rost.}

A pulvinate, large, irregular aethalium, formed of intertwined, elongated sporangia, springing from a tough hypothallus, the peripheral sporangia forming a friable, spurious cortex containing a large quantity of lime; capillitium strongly developed, threads anastomosing to form a very irregular network, furnished with irregularly stellate nodes containing granules of lime.

Fuligo, Rost., Mon., p. 134; Cooke, Myx. Brit., p. 23; Sacc., Syll., vii., 1, p. 353; Zopf, 149.

Closely approaching the genus Physarm in the structure of the capillitium, differing in its aethalioid nature, a character certainly not of generic value taken alone. The absence of a 
well-defined sporangial wall in the component sporangia forming an aethalium is what would be expected from analogy, and in the present genus the external covering of the aethalium, the cortex, consists of sterile sporangia, showing a division of labour as is often the case in various parts of the vegetable kingdom, when originally isolated structures become concentrated, as illustrated by the ray and disc florets in composite plants. The cortex is very friable, and consists largely of flake-like masses of lime, and in some cases the cortex is quite rudimentary.

Distrib. Europe; United States; Cuba; Venezuela; S. Africa; Ceylon; W. Australia; N. Zealand. Species 5.

Fuligo varians, Rost. (figs. 190-192).

Aethalium usually large, either naked, with the surface more or less venous, or covered with a cortex which is either smooth and continuous, or friab!e with flakes of lime, clear yellow, brownish, or greyish-white; capillitium abundant, forming an irregular network, with large irregularly branched nodes filled with minute granules of yellow or white lime; spores globose, pale lilac-brown, smooth, $7-11 \mu$ diameter.

Fuligo varians, Rost., Mon., p. 134; Cooke, Myx. Brit., p. 23; Zopf, p. 149.

Fuligo septica, Sacc., Syll., vii., 1, n. 1228.

Acthalium septicum, Cooke, Hdbk., n. 1101.

Acthalium vaporarium, Cooke, Hdbk., n. 1102.

Exsicc.-Roum., Fung. Gall., 1678; Rabh., Fung. Eur., 81; Thum., Fung. Austr., 523 ; Sacc., Myc. Ven., 963; Karst., Fung. Fenn., 379 ; Kunze, Fung. Sel., 298; Fuckel, Fung. Rhen., 1472 ; Desm., Crypt. France, Ser. I., n. 1844.

Amongst dead leaves, and amongst tan in greenhouses, on rotten wood, \&c. Britain (Highgate, Kew, Hereford, Scarboro', Appin, N. B.); S. Africa; India; W. Australia; New Zealand; United States; Cuba; Bolivia.

Very variable in size, form, and colour; in the plasmodium condition often occurring amongst dead leaves as a bright yellow soft moss, and hardening into yellow, crust-like patches, 
varying from one to eight or ten inches across, and nearly one inch thick. The cortex is usually bright yellow and very brittle, sometimes whitish; the lime of the capillitium also varies from bright yellow to white; spores in the mass blackish-brown.

\section{(Rostafinski's Synonyms.)}

Eponge, March., 427, t. 12 (1727).

Mucilago aestiva, Mich., t. 96, f. 1 (1729).

Mueores, Gled, p. 138, 160 (1753).

IIucor unctuosus flavus, Huds.., Fl. Ang.

Mucor septicus, Link, Sp. Pl., n. 1656 (1753); F! Dan., t.

778 ; Bolt., t. 134.

Mucor primus ovatus, Schff., t. 192 (1765).

Mucor tertius, Schff, t. 194 (1763).

Fuligo, Hall, n. 2133, 2134, 2135 (1768).

Mucor mucilago, Scop., Fl. Carn., ii., 1638 (1772).

Lycoperdon luteum, Schr., Fl. Bav., ii., 629 (1789).

Reticularia carnosa, Bull., t. 424, f. 1 (1791).

Reticularia hortensis, Bull., t. 424, f. 2 (1791).

Reticularia lutea, Bull., t. 380, f. 1 (1791).

F'uligo septica, Gmel., Sys., 1466 (1791).

Fuligo candida, Pers., Obs., i., 154 (1796).

Fuligo vaporaria, Pers., Obs., i., 155; Fl. Dan., t.1363, f. 1.

Fuligo flava, Pers., Disp., p. 8 (1797).

Fuligo rufa, Pers., Disp., p. 8 (1797).

Fuligo pallida, Pers., Obs., ii., 36 (1799).

Fuligo laevis, Pers., Syn., p. 161 (1801).

Fuligo violacea, Pers., Syn., 160 (1801); Ic. Pict., t. 1.

Reticularia septica, With. Arr., iv., 463 (1801); Purt., p. 703.

Reticularia ovata, var. With. Arr., iv., 463 (1801).

Fuligo flavescens, Schum., Saell., 1413 (1803).

Fuligo cerea, Sow., t. 399 (1803).

Aethalium flavum, Link, Diss., i., 42 (1809); Nees., f. 92;

Grev., S. C. Fl., t. 272.

Fuligo cerebrina, Brondeau, p. 74, t. 3, f. 1-4 (1824).

Fuligo varians, Somm., Fl. Lapp., p. 231 (1826). 
Reticularia vaporaria, Chev., Fl. Par., i., 342 (1827).

Aethalium violaceum, Spr. Sys., iv., 533 (1827).

Aethalium caindidum, Schlecht., in Spr. Sys., iv., 533.

Aethalium scptieum, Fr., S. M., iii., 93 (1829), Cooke, Hdbk.,

n. 1101, a. flavum, b. cinnamomeum, c. rufum, d. violaccum.

Fuligo carnosa, Duby., Bot. Gall., ii., 863 (1830).

Fuligo hortensis, Duby., Bot. Gall., ii., 863 (1830).

Acthalium rufum, Wallr., Fl. Germ., 2097 (1833).

Acthalium septicum, b. vaporarium, Rabh., Fl. Germ., 2133

(1844).

Acthalium ferrincola, Schwz. Am., 2372 (1834).

Reticularia mefe, Schwz. Am., 2377 (1834).

Acthalium rufim, Alexandr., t. 11, f. 6-11 (1872).

Acthalium vaporarium, Fr., Berk., in Gard. Chron. (1860), p. 409 ; Cooke, Hdbk., n. 1102.

\section{Fuligo stercoriformis, Mass.}

Aethalium resembling the dung of some young animal, size and shape variable, most frequently sausage-shaped, unequally gibbous, attached to the substratum throughout its length by a broad base; covered with a very friable, seceding, white cortex abounding in lime; capillitium greyish-white, tubes with numerous swollen portions containing granules of lime, combined to form a network; hypothallus rudimentary; spores ellipsoid, brown, densely covered with minute warts, $10.5-18 \cdot 5+9.3-14.5 \mu$.

Aethaliogsis stercoriformis, Zopf, p. 150, fig. 26, vii.; Sace., Syll., vii., 1, n. 1232.

On rotten leaves. Germany.

Zopf founded the genus Aethaliopsis on the mistaken supposition that the ellipsoid spores distinguished it at once amongst the Lithodermeae.

Fuligo ochracea, Peck.

Sporangia variously interwoven to form a small aethalium, springing from a delicate, whitish hypothallus, seated on a broad or narrow base; common cortex delicate, covered at first with 
rounded or irregularly branched or sinuous, minute ochraceous patches of lime; capillitium well developed, extending uniformly throughout the aethalium; nodes rather large, more or less elliptical, furnished with irregularly branched arms, filled with yellowish granules of lime, internodes thin, irregularly anastomosing; spores dingy lilac, globose, smooth, or sometimes with indications of minute warts, $7-10 \mu$ diameter.

Fuligo ochracea, Peck, 31st Report of State Mus., N. York, p. 56 ; Sacc., Syll., vii., 1, n. 1231:

Licea ochracea, Peck.

On various living and dead plants. United States; Cuba; Venezuela.

Aethalia reaching up to $1 \mathrm{~cm}$. diameter, usually smaller. Very close to Fuligo varians, if indeed distinct. The present species is in Berkeley's Herbarium from Cuba and Venezuela, marked "Aethalium pulchrum, B. and C.," but I am not aware of any published description.

\section{Fuligo simulans, Karst.}

Very similar to ecorticate forms of Fuligo varians, but the spores are darker, blackish-violet or almost black, and larger, $9-16 \mu$, generally $10 \mu$ diameter.

Fuligo simulans, Karsten, Myc. Fenn., part IV., p. 108 ; Sacc., Syll., vii., 1, n. 1230.

Yellow. On leaves of Vaccinium vitis-idaea, either unequally effused or surrounding the living stems and twigs. Finland.

Raciborski says in Hedwigia, 1887, p. 111, that the present species is the same as Fuligo varians, but he does not state that the examination of an authentic specimen has enabled him to arrive at that conclusion, hence the statement must be accepted as an opinion only.

\section{Fuligo tatrica, Racib.}

Aethalium and capillitium very similar to Fuligo varians, spores obscure violet, minutely warted, $8-10 \mu$ diameter. 
Fuligo tatrica, Raciborski, in Hedwigia, 1885, p. 169; Sacc., Syll., vii., 1, n. 1229.

On fallen trunks. Hungary.

\section{Crateriachea, Rost.}

Sporangia irregularly ruptured during dehiscence, lower portion persistent, margin lacerated. Columella central, cylindrical, containing lime. Threads of the capillitium delicate, combined to form a network, nodes not usually developed, here and there inflated and containing granules of lime, meshes of the network becoming smaller towards the periphery, terminating in short arms that are attached to the wall.

Crateviachea, Rost., Mon., p. 125 ; Sacc., Syll., vol. vii., part I., p. 358; Cooke, Brit. Myx., p. 20.

Apparently intermediate in some respects between the Lithodermeae and the Columellifcrac, departing from the former in the paucity of lime and the thin tubes of the capillitium, forming a network which originates from the elongated columella, but differing from the latter in the tendency to form nodes containing lime not being yet obliterated. Distinct from Cratcrivm in the distinct columella and rudimentary nodes of the capillitium.

Distril. Germany. Species 1.

\section{Crateriachea mutabilis, Rost.}

Sporangia cylindrical, attenuated below, then expanding into a discoid hypothallus, every part reddish-brown; spores dingy violet, globose, $8-10 \mu$ diameter, strongly warted.

Crateriachca mutabilis, Rost., Mon., p. 126, figs. 102, 103; Cooke, Myx. Brit., figs. 102, 103; Sacc., Syll., vii., 1, n. 1243.

On wood. Germany.

Sporangia $\frac{1}{2}-\frac{3}{4} \mathrm{~mm}$. high, sometimes slightly curved. 


\section{DESCRIPTION OF THE FIGURES.}

\section{PLATE 1.}

Fic. 1. Tubulina cylindrica, Bull. Portion of an aethalium broken to show the arrangement of the component sporangia ; nat. size.

2. Spore of same, $\times 1200$.

"2a. Diagrammatic view of a sporangium of same, showing the imperforate wall, the sporangia are usually hexagonal from mutual pressure, and the free apical portion convex.

3. Tubulina flexuosa, Màss., plasmodiocarp sporangia, $\times 40$.

4. Spore of same, $\times 1200$.

5. Tubulina effusa, Mass. Aethalinm eut to show section; nat. size.

6. Spore of same, $\times 1200$.

7. Trichia fragilis, Rost., a. genuina, showing single sporangium and fasciculate or aethalioid form springing from the same hypothallus, hence from the same plasmodium, $\times 40$.

8. Var. serotina, of same, $\times 40$.

9. Elater of same, $\times 500$.

10. Spore of same, $\times 1200$.

11. Cribraria intricata, Schrad. Sporangium showing stem, $a$; passing into a thin hypothallus, $b$; calyculus or lower persistent portion of sporangium, $c$; and the permanent upper portion of the sporangium, consisting of numerous nodes or irregularly angular portions filled with coloured granules of lime, and connected by long, thin internodes; the spores have been blown away, $\times 250$.

12. Unnamed species. Group of sporangia, one of which is ruptured above and showing the pale yellow spore-mass, $\times 40$.

13. Spores and portion of capillitium of same, $\times 350$.

14. Enteridium olivaceum, Ehr. Aethalium ; nat. size.

15. Fragment of sporangial walls of same, showing perforations, $\times \mathbf{3 5 0}$.

16. Spore-cluster of same, $\times 500$.

17. Single spore of same with the convex free portion (when in the cluster) warted, $\times 1200$.

18. Diagrammatic representation of a sporangium of same showing the perforated lateral wall.

19. Tilmadoche nutans, Rost. Single sporangium, $\times 50$.

20. Spores and portion of capillitium showing the small, elliptical swellings containing linıe, $a, \times 350$.

21. Spore of same, $\times 1200$. 
FIg. 22. Physarum concinnum, Mass. Two sporangia seated on the leaf of a moss, $\times 40$.

23. Spores and portion of capillitium of same, $\times 350$.

24. Spore of same, $\times 1200$.

25. Clathroptychium mugulosum, Rost. Aethalinm with a portion removed to show the bright yellow spore-mass; nat. size.

26. Upper part of a sporangium showing the permanent, convex, apical portion, $b$; with its six descending threads, $a$; corresponding to the permanent angles of the lateral wall of the sporangium, $\times 350$.

27. Spore of same, $\times 1200$.

28. Diagrammatic representation of a sporangium of same, showing the perforations in the lateral wall, which is reduced to the angles.

\section{PLATE 2.}

FIG. 29. Didyminem farinacen!n, Schrad., plant, $\times 40$.

" 30. Section of same, showing the columella, $\times 40$.

"31. Portion of same, showing the capillitium radiating from the columella, $a$, to the wall of the sporangium, $b, \times 350$.

32. Portion of inner wall of sporangium passing over the columella, showing rib-like thickenings arranged in a reticulated manner, $\times 350$.

33. Spores, $\times 350$.

34. Portion of a spore, $\times 1200$.

35. Crystals of lime from wall of sporangium, $\times 350$.

36. Chondrioderma difforme, Rost., plant, $\times 40$.

37. Section of same showing the outer calcareous wall, $a$, separated from the thin inmer wall, $b$, by a space containing air, $c, \times 40$.

38. Threads of capillitium and spores of same, $\times 350$.

39. Lepidoderma fulvum, Mass., plants, $\times 40$.

40. Spores of same, $\times 350$.

41. Lepidoderma tigrinum, Rost., plant, $\times 40$.

42. Section of same, sliowing columella, $\times 40$.

43. Portion of capillitium and spores of same, $\times 350$.

44. Didyminem microcarpa, Rost., a. nigripes; plants, $\times 40$.

45. Spores of same, -350 ; a portion of a spore, $\times 1220$.

46. Didymium squamulosum, Fr., a. genuinum; plant, $\times 40$.

47. Section of same, showing columella, $\times 40$.

48. Spores of same, -350 ; portion of a spore, $\times 1200$.

49. Didymium squamulosum, Fr., var. costatum, Mass., plant, $\times 40$.

50. Didymium squamulosum, var. virgineum. Mass., plants, $\times 40$.

51. Section of same to show columella, $\times 40$.

52. Portion of capillitium and spores of same, . 350 ; a portion of a spore, $\times 1200$. 
Fig. 53. Didymirum clavus, Rost., plants, $\times 40$.

54. Portion of capillitium and spores of saine, $\times 350$.

55. Didymium serpula, Fr., plants, $\times 40$.

56. Portion of capillitium of same, $\times 350$.

57. Spores of same, $\times 330$; a portion of a spore, $\times 1200$.

58. Chondrioderma floriforme, Rost., plants ; $a$, before dehiscence; $b$, after dehiscence, $\times 40$.

59. Spores of same, $\times 350$; portion of a spore, $\times 1200$.

\section{PLATE 3.}

Fig. 60. Physarum lencopus, Rost., plants, $\times 40$.

61. Portion of capillitium and spores of same, $\times 350$.

62. Spore of same, $\times 1200$.

63. Physarum leucophaeum, Fr., plants, $\times 40$.

64. Portion of sporangial wall of same, showing innate patches of lime, $\times 200$.

65. Portion of capillitium and spores of same, $\times 350$.

66. Spore of same, $\times 1200$.

67. Hybrid between Physarum leucopus and Physarum leucophaeum, $\times 40$.

68. Physarum granulatum, Balf., fil., plant, $\times 40$.

69. Portion of capillitium and spores of same, $\times 350$.

70. Spore of same, $\times 1200$.

71. Physarum cinereum, Rost., plants, $\times 40$.

72. Portion of capillitium and spores of same, $\times 350$.

73. Spore of same, $\times 1200$.

74. Badhamia panicea, Rost., plants, $\times 3$.

75. Portion of capillitium and spores of same, $\times 350$.

76. Spore of same, $\times 1200$.

77. Physarum Phillipsii, Balf., fil., plants, $\times 40$.

78. Spore of same, $\times 1200$.

79. Badhamia macrocarpa, Rost., var. sessilis, Rost., plants, $\times 40$.

80. Portion of capillitium and spore of same, $\times 350$.

81. Spore of same, $\times 1200$.

82. Physarum didermoides, Rost., plants, $\times 40$.

83. Portion of capillitium and spores of same, $\times 350$.

84. Spore of same, $\times 1200$.

85. Badhamia fusea, Mass., plants, $\times 40$.

86. Spore of same, $\times 1200$.

87. Chondrioderma Oerstedii, Rost., plants, $\times 40$; $a$, before, $c$, after dehiscence.

88. Spore of same, $\times 1200$. 


\section{PLATE 4.}

FIG. 89. Chonidrioderma niveum, Rost., plants, $\times 40$.

" 90. Chondrioderma Trevelyani, Rost., plants, $\times 30$.

"91. Spore of same, $\times 1200$.

"92. Chondrioderma radiatum, Rost., plants, $\times 40$.

" 93. Didymium tucsilaginis, Mass., plants, $\times 40$.

"94. Portion of capillitium and spores of same, $\times 400$.

"95. Swollen angles of eapillitium of same, showing crystals of lime, $\times 1200$.

96. Physarum leucophaenm, var. violascens, Rost., plants, $\times 40$.

97. Didymium Listeri, Mass., plants ; nat. size.

98. Portion of eapillitiun and spores of same, $\times 400$.

99. Section of sane, $\times 40$.

100. Spore of same, $\times 1200$.

101. Crystals of lime from wall of sporangium of same, $\times 400$.

102. Dilyminm dubium, Rost., portion of enpillitium, $\times 400$.

103. Cribravia mifa, Rost., plant after the spores have been blown away, $\times 80$.

104. Cribraria anrantiaca, Schrad., plant after the spores have been blown away, $\times 80$.

105. Cribraric, aryillacea, Pers., plants, $\times 40$.

106. Portion of inner permanent wall of sporangium of same, $\times 400$.

107. Spore of same, $\times 1200$.

108. Spore of Enteridium Rozeanm, Wing., $\times 1200$.

109. Cribraria perperea, Schral., portion of permanent wall of sporangium, $\times 400$.

"110. Cribraria macrocarpa, Schrnd., $\times 80$.

"111. Siphoptychium Casparyi, Rost., showing the prismatic sporangia with slightly convex apices, sone have the lateral wall removed showing the long, slender, eentral columella with its lateral branclies, $\times 60$.

" 112. Stemonitis dictyospera, Rost., spore, $\times 1200$.

" 113. Arcyira fuliyinea, Mass., portion of capillitium, $\times 750$.

\section{PLATE 5.}

Fig. 114. Perichaena corticalis, Mass., sporangia of pale form,$\times 40$.

"115. Sporangium of dark form of same, $\times 40$.

"116. Spores and portion of capillitium of same, $\times 350$.

"117. Spore and portion of capillitium of same, $\times 1200$.

"118. Perichaena depressa, Lib., sporangia showing dehiscent lid, $\times 40$.

"119. Sporangia of same, seen from above, $\times 40$.

$" 120$. Spores aud portion of capillitium of same, $\times 350$. 
Fig. 121. Lycogala epidendrum, Bux. ; nat. size.

122. Spore and portion of capillitium of same, $\times 1200$.

123. Lycogala flavo-fusca, Rost. ; nat. size.

124. Arcyria clavata, Mass, base of sporangium and stem, showing the latter filled with large cells which become smaller upwards and pass gradually into normal spores, $\times 100$.

125. Sporangia of same, $\times 40$.

126: Spores and portion of capillitium of same, $\times 350$.

127. Prototrichia cuprea, Mass., sporangia, $\times 40$.

128. Spores and branched elater of same, $\times 350$.

129. Spore of same, $\times 1200$.

130. Prototrichia flagellifer, Rost., sporangium split open showing the flesh-coloured mass of spores, $\times 40$.

131. Spores and branched elater of same, $\times 350$. :

132. Spore of same, $\times 1200$.

133. Dictydium cernuum, Mass., sporangium, after the spores have been blown away, showing the calyculus or persistent basal portion of the sporangial wall, $a$; the persistent latticed portion of the remainder of the sporangial wall, $b$; and the shrivelled apical portion of the sten, $\times 100$.

134. Cribraria macrocarpa (Schrad.), R., sporangia showing at $a$ the original continuous sporangial wall ; at $b$ the external portion of the wall has fallen away, leaving only the thickened persistent portion, the spores have been blown away, $\times 40$.

135. Portion of permanent network of the sporangial wall of same, showing the nodes, $a$, filled with granules of lime, connected by the thin, elongated internodes, $b$, destitute of lime, $\times 350$.

136. Spore of same, $\times 1200$.

137. Arcyria cinerea, Mass., sporangia, $\times 40$.

138. Portion of capillitium and spores of same, $\times 350$.

139. Portion of capillitium, $\times 1200$.

140. Arcyria nutans, Rost., sporangia $a$, before, $b$, after dehiscence; $c$, the long, elastic capillitium, $\times 50$.

141. Portion of capillitium of same, $\times 1200$.

142. Trichia advenula, Mass., group of sporangia, $\times 40$.

143. Spores and portion of an elater of same, showing the smooth, long apiculus and interstitial swelling, $\times 350$.

144. Spore of same, $\times 1200$.

\section{PLATE 6.}

Fig. 145. Lamproderma arcyrioides, Rost., plants, $\times 40$.

"146. The same after the sporangial wall and mass of spores have fallen away, showing $a$, base of wall of sporangium; $b$, columella; $c$, capillitium; $d$, stem, passing into the hypothallus, $e$, $\times 100$. 
Fig. 147. Portion of capillitium and spores of same, $\times 350$.

"148. Spore of same, $\times 1200$.

" 149. Lamproderma iridea, Cooke, plants, $\times 40$.

$"$ 150. Spores of same, $\times 350$.

"151. Portion of capillitium and spores of same, $\times 350$.

"152. Lamproderma violacea, Rost., plants, $\times 40$.

"153. Portion of capillitium of same, $\times 350$.

154. Spores of same, $\times 1200$.

155. Stemonitis fusca, Rost., group of plants ; nat. size.

156. Single plant of same with the sporangial wall and spores blown away, showing the dense capillitium, $\times 100$.

157. Portion of capillitium and spores of same ; $a$, part of columella ; $b$, main branches of capillitium originating from the columella, which branch and anastomose irregularly, the meshes becoming small towards the periphery, $\times 350$.

158. Stemonitis Carlylei, Mass., group of plants, $\times 10$.

"159. Portion of capillitium and spores of same, $\times 350$.

" 160. Stemonitis fermininea, Ehr., plants, $\times 8$.

"161. Portion of capillitium and spores of same, $\times 350$.

" 162. Stemonitis fusca, R., var. $a$. ; plants, $\times 6$.

"163. Portion of capillitium and spores of same, $\times 350$.

" 164. Spore of same, $\times 1200$.

" 165. Diachaea leucopoda, Rost., plant, $\times 25$.

"166. Spores of same, $\times 350$; one spore, $\times 1200$.

\section{PLATE 7.}

FIG. 167. Didymium sinapinum, Mass., plants, $\times 40$.

168. Spores of sane, $\times 350$; a portion of one $\times 1200$.

169. Trichia varia, var. nigripes, Rost., plants, $\times 40$; $a$, before deliscence; $b$, after deliscence.

170. Trichia varia, var. gemina, Rost., plants, $\times 40$.

171. Spores of same, $\times 350$.

172. Portion of spore and tip of elater of same, $\times 1200$.

173. Trichic Carlylei, Mass., plants, $\times 40$.

174. Spores and an elater of same, $\times 350$.

175. Portion of sporangial wall of same, seen from the inside, showing the purple masses of organic matter, $\times 350$.

176. Badhamia nitens, Berk., plants, $\times 40$.

177. Spores of same; $a$, in clusters ; $b$, detached, $\times 350$.

178. Single spore of same, $\times 1200$.

179. Portion of capillitium of same, $\times 350$.

180. Trichia intermedia, Mass., plants, $\times 40$. 


\section{Description of the Figures.}

FIG. 181. Two spores of same, showing the extreme variations of markings ; $a$, having the bands all united to form a network; $b$, having the bands not at all combinerl, $\times 1200$.

"

9)

182. Portion of an elater of same, $\times 1200$.

183. Trichia purpurascens, Nyl., plants, $\times 40$.

184. Spores and elaters of same, $\times 350$; portion of a spore, $\times 1200$.

185. Oligonema Broamei, Mass., plants, $\times 40$.

186. Spores and elater of same, $\times 350$.

187. Leocarpus fragilis, Rost., plants, $\times 25$.

188. Pale-coloured form of same, $\times 25$.

189. Portion of capillitium and sfores of same, $\times 350$; portion of a spore, $\times 1200$.

190. Fuligo varians, Rost., a small specimen ; nat. size.

191. Section of same; nat. size.

192. Portion of capillitium and spores of same, $\times 350$.

193. Oligonema nitens, Rost., group of plants, $\times 40$.

194. Portion of capillitium of same, $\times 350$.

195. Spore of same, $\times 1200$.

\section{PLATE 8.}

FIG. 196. Physarum tenerum, Rex., $\times 100$.

197. Ophiotheca Wrightii, Berk. and Curtis; portion of capillitium thread, $\times 1200$.

"198. Ophiotheca vermicularis, Mass, portion of capillitium thread, $\times 1230$.

„198a. Spore of same, $\times 1200$.

"199. Ophiotheca reticulata, Mass., group of specimens showing various forms of the venulose plasmodiocarp, $\times 50$.

"200. Portion of same showing the numerous free arms, $a$, $a$, of the capillitium, and the attachment of the latter to the wall of the sporangium, $b, \times 600$.

"201. Orcadella operculata, Wingate; two entire specimens; $a$, the deciduous operculum, $\times 100$.

"202. Lamproderma Listeri, Mass., showing a specimen after the disappearance of the sporangial wall, and the dispersion of the spores ; $a$, stem, passing into the hypothallus, $b$; $c$, remains of the wall of the sporangium, which forms a frill round the apex of the stem; $d$, columella, which in the present specimen is expanded in an irregularly discoid manner at the apex; $e$, threads of the capillitium which originate from the discoid apex of the columella, $\times 400$.

"203. Spore of same, $\times 1200$.

,

204. Lachnobolus globosus, Schweinitz. A specimen growing on a spine of the involucre of the sweet chestnut; $a$, the basal permanent portion of the sporangium, $\times 100$. 
FIG. 205. Heterotrichia Gabriellae, Mass., two entire specimens : a, before, $b$, after deliscence, and showing the protruded capillitium, $\times 80$.

206. Spores and portion of capillitium of same; $a$, thin inner portion of capillitium without free ends; $b$, thick, peripleral portion of capillitium with numerous, pointed, free ends, $\times 500$.

207. Didymium neglectum, Mass., section of sporangium; $a$, columella; $b$, wall of sporangium covered externally with minute granules of lime; $c$, threads of capillitium, $\times 200$.

208. Didymium anstralis, Mass., single specimen showing the shallow umbilicus on the under surface of the sporangium, $\times 100$.

209. Echinostelinem minutum, Rost., portion of capillitium. (After Rostafinski.)

210. Physarum conglomeratum, Fries, a group of specimens seen from above, $\times 100$. (Drawn from a specimen named by Fries.)

211. Section of a sporangium of same, $\times 150$.

212. Spores and a portion of the capillitium of the same, $\times 400$.

\section{PLATE 9.}

FIa. 213. Craterium cylindricum, Mass., $\times 100$.

214. Physamum ellipsosporum, Rost., spore, $\times 1200$.

215. Physarum flavum, Fries, entiro specimen, $\times 100$ (figured from specinen by Fries).

216. Chondriolerma virginea, Mass., two specimens showing the sinooth wall and irregular mode of dehiscence, $\times 80$.

217. Clusters of the same growing on a dead leaf ; nat. size.

218. Spore of same, $\times 1200$.

219. Section of a sporangium of same, showing columella and capillitium, $\times 100$.

220. Portion of capillitium and spores of same, $\times 400$.

221. Physcerum brunneolum, Phil., two entire specimens; $a$, before, $b$, after deliscence, $\times 100$.

222. Section of same, showing the very numerous, large nodes of the capillitium, $\times 300$.

223. Lepidoderma stellata, Mass., young specimen, showing the originally continuous white crust of bicarbonate lime just beginning to break up into large, detached, persistent patches, $\times 150$.

224. Two specimens of same; $a$, before, $b$, after dehiscence, which takes place in a stellate manner from the apex, $\times 150$.

225. Section of same, showing the columella and capillitium, $\times 150$.

226. Didymium longipes, Mass, three specimens, showing irregular mode of dehiscence; $a$, liypothallus, $\times 100$.

227. Didymium proximum, Berk. and Curt., specimens growing on deal grass ; nat. size.

228. Two specimens of same; $a$, showing the elongated columella, which is very brittle and easily broken off, $\times 100$. 


\section{Description of the Figures.}

FIG. 229. Portion of capillitium and spores of same, $\times 400$. (All the figures are drawn from the type specimen in Herb. Berk., Kew, n. 10,760.)

"

230. Lepidoderma reticulatum, Mass., two specimens, showing variety of form assumed by the plasmodiocarp, $\times 100$.

231. Physarum scyphoides, Cooke and Balfour, three specimens; a, after dehiscence, showing the columella ; $b$, showing the irregularly circumscissile mode of dehiscence, $\times 100$.

232. Didymium fulvellum, Mass., single specimen showing the frosting of lime partially removed from the sporangium, $\times 200$.

233. Trichia superba, Mass., spore showing the raised, flat bands combined to form a nearly polygonal network; the flat surface of the flat raised band is ornanented with a row of minute depressions, $\times 1200$.

234. Physarum Ravenelii, Mass., single specimen, $\times 100$.

235. Portion of capillitiun and spores of same, $\times 400$.

\section{PLATE 10.}

FIG. 236. Tilmadoche mutabilis, var. auerantiaca, Rost., plant, $\times 40$.

,

,

237. Portion of capillitium and spores of same, $\times 350$.

238. Spore of same, $\times 1200$.

239. Tilmadoche mutabilis, var. lutea, Rost., plants, $\times 40$.

240. Physarum Carlylei, Mass., plant, $\times 40$.

241. Portion of capillitium and spores of same, $\times 350$.

242. Arcyria punicea, Rost., plants, $\times 40$.

243. Portion of capillitium and spores of same, $\times 350$.

244. Portion of capillitium of same, $\times 1200$.

245. Chondrioderma Carmichaeliana, Mass., plants, $\times 40$.

246. Section of same, $\times 40$.

247. Portion of capillitium and spores of same, $\times 350$.

248. Arcyria cinerea, Mass, plant, $\times 40$.

249. Spores of same, $\times 350$.

250. Arcyria furruginea, Sauter., plants, showing the various forms of sporangium; in $a$, the sporangium has been ruptured by the elastic capillitium, $b, \times 40$.

251. Portion of capillitium and spores of same, $\times 350$.

252. Spore of same, $\times 1200$.

253. Portion of capillitium thread of same, $\times 1200$.

254. Brefeldia maxima, Rost., plant; nat. size.

255. Portion of capillitium and spores of same, $\times 350$.

256. Spore of same, $\times 1200$.

257. Craterium aureum, Rost., plant, $\times 40$.

258. Portion of capillitium and spores of same, $\times 350$.

259. Spore of same, $\times 1200$. 
FIG. 260. Craterium aucreum, Rost., plant, $\times 40$.

,261. Portion of capillitium and spores of same, $\times 350$.

"262. Arcyria muliformis, Rost., $a$, the stipitate, faseiculate form ; $b$, sessile form; in $c$, the sporanginm has dehiseed in a circunscissile manner, the apical portion, $d$, being carried up by the elastic capillitium, $e, \times 40$.

"263. Portion of capillitium and spores of same, $\times 350$.

"264. Spore of same, $\times 1200$.

"265. Cratcrinum Friesii, Rost., $\times 40$.

PLATE 11.

FIr. 266. Ceinkowskir reticulata, Rost., specimen, $\times 40$.

"267. Spores and portion of capillitium of same, showing the free, curved, pointed tips, $a, a, \times 400$.

"268. Arcyria chrysospora, Mass., spore, $\times 1200$.

269. Free apex of thread of capillitium, $\times 1200$.

270. Arcyric Bucknulli, Mass., tip of elater, $\times 1200$.

271. Spore of same, $\times 1200$.

272. Arcyria paradoxa, Mass., portion of an elater, $\times 1200$.

273. Arcyria serpula, specimen, $\times 40$.

274. Tip of elater of same, $\times 1200$.

274 2 . Spore of same, $\times 1200$.

275. Physarum cerchrinum, Mass., specimen, $\times 40$.

276. Physarnem contestum, specimen, $x-40$.

277. Spores and portion of capillitium of same, $\times 350$.

278. Spore of same, $\times 1200$.

279. Physarum virescens, sesslle form, $\times 40$.

280. Stipitatc form of same, $\times 40$.

281. Aethalioid form of same, $\times 2$.

282. Portion of eapillitium and spores of same, $\times 350$.

283. Spore of same, $\times 1200$.

284. Physarnum conglomeratum, Fries, group of sporangia, $\times 40$.

285. Spores and portion of capillitium of same, $\times 350$.

286. Spore of Eame, $\times 1200$.

287. Physarum. Schumacheri, plants in different stages of development, the one to the left with the sporangium broken away and showing the columella, $\times 40$.

288. Spore of same, $\times 1200$.

"289. Craterium confusum, Mass, group of sporangia, $\times 40$.

\section{PLATE 12.}

FIG. 290. Physarum psittacinum, plant, $\times 40$.

"291. Spores and portion of capillitimu of same, $\times 350$. 


\section{Description of the Figures.}

FIG. 292. Physarum sinuosum, entire plants after dehiscence, $\times 40$.

293. Section of same, $\times 50$.

294. Badhamia macrocarpa, sessile scattered form, $\times 50$.

295. Stipitate form of same, $\times 50$.

296. Spores and portion of capillitium attached to sporangial wall of same, $\times 350$.

297. Spore of same, $\times 1200$.

298. Craterinm leucocephalum, specimens showing the various stages of dehiscence, $\times 50$.

299. Vertical medium section of same showing the irregnlar columella, dense capillitium, and perforations in the wall, $a, \times 100$.

300. Portion of wall of sporangium of same, seen from the inside, showing the general crust of lime in the form of very minute granules, the circular discs of organic matter, $a$, and the cavities from which the discs have been removed, $b, \times 400$.

301 . One of the discs of organic matter removed from wall. of same, $\times 400$.

302. Enerthenema elegans, specimen from which the wall of the sporangium has been removed and the spores blown away, showing the thin columella with its apical disc-like portion from which the capillitium originates, a fragment of the basal portion of sporangial wall still adhering to the stem is marked, $a, \times 50$.

303. Portion of capillitiun' and spores of same, $\times 350$.

304. Spore and portion of capillitium of same, $\times 1200$.

305. Craterium dictyospermim, $\times 50$.

306. Median vertical section of same, showing the columella and capillitium, $\times 100$.

307. Craterium lilacinum, $\times 50$.

308. Spore of same $\times 1200$.

309. Craterium rubiginosum, $\times 50$.

310. Spore of same, $\times 1200$.

311. Reticularia lycoperdon, a. castaneum; nat. size.

312. Spore of same, $\times 1200$.

313. Chondrioderma Michelii, $a$, hypothallus, $\times 50$. 


\section{GENERA AND SPECIES EXCLUDED.}

Endocalyx, B. and Br., belongs to the Fungi.

Reticnlaria affinis, B. and C.,

$"$ atro-rufa, B. and C., $\}=$ Trichosporium Curtisii,

" venulosa, B. and C., $\}$ Mass., Journ. Myc., 1889.

Reticularia phyrrhospora, Berk., $\{$ Trichosporium phyrrhorubra, Ayres. $\{=$ sporium, Mass., Journ.

Reticularia apiospora, B. and Br., $\left\{\begin{array}{c}\text { Trichosporium apio- } \\ \text { sporium, Mass., Journ. } \\ \text { Myc., 1889. }\end{array}\right.$

Badhamia fulvescens, Cke., is probably a member of the Perisporiaceae.

Didymium bulbillosum, $\mathrm{Br}$. and $\mathrm{Br}$., = minute galls on a leaf, as proved by examination of type.

\section{BIBLIOGRAPHY.}

Baranetzki; Influence de la lumière sur les plasmodia des Myxomycetes. Mem. Soc. Nat. de Sci. Nat. de Cherbourg, v., xix.

Bary, De; Morphology und Physiologie der Pilze, Mycetozoen und Bacterien; Leipzig, 1866 (English edition, Clarendon Press, 1887). 1859. 
Brefeld; Dictyostelium mucoroides; Abhandl. der Senk. Nat. Gesell., vii., 1869.

Brunchorst, T.; Spongospora Solani (a new Myxomycete causing disease in potato); Bergens Museums Aarsberet, 1877 (2 Pl.).

Bulliard; Hist. des Champignons.

Candolle, De ; Flore Française; fungi in vol. ii.

Cienkowski, I. ; Entwick. der Myxomyceten ; Pringish. Jahrb., iii.

—; Guttulina rosca, Bot. Jahresb., 1873, p. 61.

; Zur Entwickel. der Myxomyceten; Jahrb. für Wiss., Bot. iii., 1862.

_; Das Plasmodium; Jahrb. fiir Wiss., Bot. iii. 1863.

Cooke, M. C.; Myxomycetes of Great Britain, 1877.

Crouan, P. I., and H. M.; Florule de Finisterre, 1867.

Dangeard, M. P. A. ; Recherches sur les organisms inférieurs; Ann. Sci. Nat. (Bot.) iv. (1886), ( 4 Pl.).

Fayod, V.; Beitrag zur Kenntniss niederer Myxomyceten; Bot. Ztg., 1883.

Fries, E. ; Systema Mycologicum; vol. iii. (1829).

—_ Stirpium agri Femsjonensis (1825, 1826).

- ; Summa Vegetabilium Scandinaviae (1846).

Fuckel, L.; Symbolae Mycologicae (1875, concluded).

Gobi, C. ; Pseudospora, structure and development of; Ber. Gesell. öff Gesundh.; Petersburg, 1887 (in Russian); (abstract in Bot. Centralbl., 39 (1889), p. 346.

Greville, R. K. ; Flora Edinensis (1824).

; Scottish Cryptogamic Flora, 1823-1829.

Henfrey; Notes on the elaters of Trichia; Trans. Linn. Soc., v., 21 , p. 221 .

Hisinger, E.; Tetramyza parcesitica (producing tubercles on muppia rostellata and zanichellia polycarpa). Meddl. Soc. pro Faun. et Flor. Fennica, 1887.

Lister, A; Notes on the plasmodium of Radhamia utriculosa and Brefeldia maxima; Annals of Botany, vol. ii., 1888 (2 Pl.).

— N Notes on Chondrioderma difforme and other Mycetozoa; Ann. Bot., vol. iv. (1890) (1 Pl.). 
Lister, A. ; New species of Mycetozoa ; Journ. Bot., 1891 (4 P1.). Massee, G.; A revision of the Trichiaceae; Journ. Roy. Micr. Soc., 1889 (4 Pl.).

—; Mycological Notes; Journ. Mycol., vol. v., 1889.

Persoon, D. C. H.; Observationes Mycologicae, 1796-1799.

— : Synopsis Methodica Fungorum, 1801.

Raciborski, M.; Myxumyceten der Tatra; Hedw., 1885, p. 168 .

- ; Bemerk. über einige in den letzten Jahren beschrieb. Myxomyceten; Hedw., 1887, p. 109.

Raunkier, C.; Myxomycetes Daniae; Bot. Tidsskr. (18881889).

Rex, G. A. ; A remarkable variation of Stemonitis Bauerlinii, Massee; Proc. Acad. Nat. Sci. Phil., 1890, p. 36.

Rosanoff; De l'influence de l'attraction terrestre sur la direction des Plasmodia des Myxomycètes; Mem. Soc. Imp. Sc. Nat. Cherb., vol. xiv.

Rostafinski, J.; Versuch cines Systems der Mycetozoen (Inaugural I)issertation), Strassburg, 1873.

—; Sluzowce (Mycetozoa), Monogratia (In Polisl, numerous figures); Paris, 1875.--Supplement to above, Paris, 1876.

Roze, E. ; Des Myxomycètes et de leurs place dans la système. Bull. Soc. Bot. France, vol. xx., p. 320 (1873).

Saccardo; Myxomycetes; in "Sylloge Fungorum," vol. vii., pt. I.

Schroeter, J.; Myxomycetes, in Cohn's Kryptogamen-Flora Von Schlesien, 1885.

Schumacher, C. F.; Enumeratio Plantarum Saellandiae, 1801.

Schweinitz, L. D. de; Synopsis Fungorum Carolinae; Soc. Nat. Curio. Lips., 1882.

- ; Synopsis Fungorum in America Boreali media degentium. Trans. Amer. Phil. Soc., vol. iv., New Ser. (1834).

Stahl, E. ; Zur Biologic der Myxomyceten; Bot. Ztg. (1884), $145,146,161-176,187-191$.

Tieghem, Ph. Van; Traité de Botanique, 1884.

— ; Sur quelques Myxomycètes a plasmode agrégé; Bull. Soc. Bot., xxvii., 1880. 
Wallroth, F. G. ; Flora Cryptogamica Germaniae, 1833.

Ward, H. M.; The Morphology and Physiology of an aquatic Myxomycete; Studies from the Biological Laboratories of the Owens College, vol. i. (1886).

Wigand; Zur Morphologie der Gattungen Trichia und Arcyria; Jahrb. fur. Wiss. Bot., iii. (1862).

Wingate, H.; Orcadella, a new genus of Myxomycetes; Rev. Mycol. (1890), p. 74, 75.

Woronin and Famintzin; Ceratium Hydnoides and $C$. poroidcs. Mem. de l'acad. Imp. des. 'Sc. de St. Petersb., vii., ser. T., n. 3, 1873.

Woronin; Plasmodiophora Brassicae; Jahrb. fur. Wiss. Bot., xi., p. 548 (1878).

Zoff, W.; Vorkommen von Fettfarbstoffen bei Pilzthieren. (Mycomyceten); Flora; lxxii. (1889), pp. 353-361 (1 fig.).

- ; Ueber Pilzfarbstoffe (including some of the Myxomycetes); Bot. Ztg., xlvii. (1889), 54-61, 69-81, 85-92 (1 Pl.).

-; Die Pilzthiere oder Schleimpilze; in Schenk's "Handbuch der Botanik," parts 15, 16 (1884).

Zukal, H, ; Einig neue Pilze, Myx. und Bact. (contains descriptions of two new Myxogastres, Trichia nana and Amaurochacte speciosa); Verhandl. K. K. Zool.-Bot. Gesell. Wien., xxxv. (1885), pp. 332-345 (1 Pl.). 


\title{
INDEX OF GENERA.
}

\author{
Synonyms are printed in Italics.
}

Aluvisia, B. and Br., 126.

Amaurochaete, Rost., 89.

Ancyrophorus, Raunk., 107. Arcyria, Hill, 141.

Badhamia, Berk., 316.

Brefeldia, Rost., 90.

Chondrioderma, Rost., 197.

Chromosporium, Sacc., 93.

Cienkowskia, Rost., 336.

Clathroptychium, Rost., 50.

Comatricha, Preuss., 72.

Cormuvia, Rost., 126, 130.

Crateriachea, Rost., 314.

Craterium, Toent., 262.

Cribraria, Pers., 54.

Dermodium, Rost., 120.

Diachaea, Fries., 258.

Dictydium, Schrad., 67.

Didymium, Schrad., 218.

Echinostelium, De Bary, 108. Enerthenema, 130wu., 104.

Enteridium, Rost., 44.

Fuligo, Rost., 339.

Hemiarcyria, Rost., 141.

Heterodictyom, Rust., 54 .

Heterotrichia, Mass., 139.
Lachnobolus, Fries., 136.

Lamproderma, Rost., 94.

Leocarpus, Rost., 337.

Lepidoderma, De Bary, 251.

Licea, Schrad., 35.

Lindbladia, Fries, 35.

Lycogala, Mich., 119.

Lycoperdon, Bux., 120.

Oligonema, Rost., 169.

Ophiotheca, Curr., 130.

Orcadella, Wing., 48.

Orthotrichia, Wing, 109.

Perichaena, Fries, 113, 130.

Physarum, Pers, 273.

Protoderma, Rost., 43.

Protodermium, Rost., 43.

Prototrichia, Rost., 126.

Raciborskia, Berl, 108.

Reticularia, Bull., 92.

Rostafinskia, Speg., 91, 108.

Siphoptychium, Rost., 88.

Spumaria, Pers., 256,

Stemonitis, Gled., 72 .

Tilmadoche, Rost., 327.

Trichia, Haller., 126, 173.

Tubulina, Pers., 35. 


\title{
INDEX OF SPECIES.
}

\author{
Synonyms are in roman type.
}

Abrupta (Trich.) 187. acuminata (Stem.) 78. Adnata (Arey.) 145. advenula (Trich.) 181. aeneum (Olig.) 172. affine (Phys.) 283. affine (Chon.) 210. affine (Didy.) 222. affinis (Coma.) 77. affinis (Arcy.) 157. affinis (Trich.) 194. affinis (Stem.) 77. alba (Spum.) 256. albescens (Chon.) 209. albesscens (Dider.) 209. Albicans (Phys.) 312.4

Alexandrowiczii (Chon.) 212. Alexandrowic ii (Badh.) 324. Alexandrowiczii (Didy.) 232. angulatum (Didy.) 249. anomala (Tilm.) 333. anomala (Ophi.) 135. anomala (Trich.) 135. anomala (Corn.) 135. anomalum (Didy.) 245. anomalum (Chon.) 245. antiades (Trich.) 314. antiides (Sphaer.) 314. antiades (Phys.) 313. applanata (Retic.) 45. applanata (Peri.) 116. applanata (Hemi.) 117. arcyrella (Lach.) 138. arcyrioides (Lamp.) 95 . arcyrioides (Lamp.) 102. arcyrionema (Lamp.) 96. aryillacea (Crib.) 65. argillacea (Crib.) 37. artocreas (Peri.) 135. atra (Stem.) 78. $\operatorname{atra}$ (Amaur.) 89. atropurpureum (Lyco.) 121. atroribrum (Phys.) 294. atrum (Phys.) 314, 315. aurantiaca (Arcy.) 155. aurantiaca (Crib.) 57. aureum (Crat.) 269. australe (Steg.) 119. australis (Rost.) 92. austrulis (Didy.) 237, australis (Peri.) 119.

Balfouri (Trich.) 186. Barteri (Didy.) 231.

Bauerlinii (Stem.) 79. Bavarica (Olig.) 170. Bavarica (a) 170.

Berkeleyana (Ener.) 106. Berkeleyanum (Chon.) 214. Berkeleyi (Phys.) 285. Berkeleyi (Phys.) 242. Berkeleyi (Clat.) 53. Berkeleyi (Tilm.) 332. bicolor (Arcy.) 153. bieniaszii (Crib.) 60. bieniaszii (Heter.) 61. bombarda (Proto.) 128. Bonariensis (Arcy.) 157. botryoides (Didy.) 229. botrytis (Trich.) 176. Braunianum (Phys.) 308. brevifilum (Olig.) 173. Broomei (Olig.) 172, brunnea ('Tubu.) 42. brunnea (Licea) 42.

brunneolum (Phys.) 280. 
brunneolum (Dider.) 281.

Bucknalli (Arcy.) 161.

Bucknalli (Hemi.) 161.

caespitosa (Tubu.) 43.

crespitosum (Phys.) 43, 311.

culcarenm (Chon.) 218.

calyculata (Arcy.) 162.

calycnlata (Hemi.) 162.

candidum (Plyys.) 286.

canoftavescens (Ophi.) 134.

Capense (Phys.) 309.

capsulifera (Badh.) 319.

Curestianum (Lepi.) 255.

Carestiana (Reti.) 255.

Carlyleuna ('Trich.) 174.

Carlylei (Phys.) 293.

Carlylei (Stem.) 84.

Carmichaelianum (Chon.) 202.

Carmichuelianum (Didler.) 202.

Casparyi (Siph.) 89.

curipes (Tilm.) 333.

cercbrinum (Phys.) 306.

ceruuum (Dict.) 67.

Chailettii (Lepi.) 255.

Chamacleontina (Proto.) 130.

chondroderma (Didy.) 232.

chrysopeplum (Phys.) 275.

chrysosperma (Oplii.) 131.

chrysosperma (Trich.) 189.

chrysospora (Arcy.) 164.

chrysospora (Iemi.) 164.

Chrysotrichum (Phys.) 300.

cinerea (Arcy.) 151.

rinerea (Arcy.) cribrnides (Vur.) 153. cineremu (Phys.) 301.

cinereum (l'hys.) 310.

cinereum (Phys.) 298.

cimaharina (Licen) 52.

cimaburinum (Clat.) 53.

cinsamomeal (Arcy.) 158.

circinans (Lach.) 139.

circumscissn (Corn.) 131.

eircumscissa (Ophi.) 131.

citrinellum (Phys.) 278.

citrinum (Phys.) 275.

citrinum (Phys.) 278.

clavata (Arcy.) 165.

clavata (Hemi.) 166.

clavis (Didy.) 230.

coadmata (Badh.) 325.

columbina (Tilm.) 331.

columbinum (Phys.) 332.

columbinum (Didy). 331. confluens (Coma.) 77. confluens (Didy.) 235. comflusus (Stem.) 77. conifusa (Peri.) 117.

confusa (Diac.) 259.

conifusum (Crat.) 263. columbirum (Lamp.) 100. commutable (Didy.) 229. compacta (Tilm). 332. complanatum (Didy.) 234. compresseum (Phys.) 286. concinnum (Dider.) 308. concinnum (Phys.) 308. congesta (Lach.) 139. congestum (Didy.) 292. conglomeratum (Phys.) 301. conglomeratum (Phys.) 304. conglomeratum (Dider.) 301. conicum (Dermo.) 123. conicum (Lyco.) 123. connatum (Didy.) 251. contertum (Phys.) 303. contorta (Trich.) 182. Cookei (Didy.) 245.

Conkei (Chon.) 245.

Cookei (Chon.) 207. Cookei (Arcy.) 154. corticalis (Peri.) 115. corticalis (Peri.) 135. crassipes (Ancy.) 107. cribrarioides (Stem.) 104. cribroicles (Var.) 144. croceo-tlavium (Didy.) 277. cmestaceum (Chon.) 215. crustaceum (Dider.) 215. crustaceum (Didy.) 235. cmustuceum (Dider.) 215. cubense (Chon.) 213. cupren (Proto.) 129. cupripes (Phys.) 284. Curtisii (Didy.) 272. Curtisii (Crat.) 272. Curtisii (Badh.) 272. Curtisii (Scyp.) 272. cyliudrica ('Tubu.) 39. cylindrica (Licea) 53. cylindricum (Crat.) 268.

daedaleum (Didy.) 250. dealbata (Chon.) 207. dealbatum (Didy.) 208. Decaisneana (Trich.) 185. decipiens (Arcy.) 158. decipiens (Arcy.) 157. 
decipiens (Badh.) 300.

deplanatum (Chon1.) 215. depressa (Peri.) 114. dictydioides (Crib.) 65. dietyocarpa (Corn.) 131. dictyonema (Arcy.) 154. dictyospermum (Crat.) 270. dictyospora (Badh.) 271. dictyospora (Stem.) 83. diderma (Phys.) 304. didermoides (Phys.) 291. difforme (Clion.) 213. digitata (Stem.) 153. digitata (Arcy.) 153. discoiderm (Didy.) 229. dissiliens (Clat.) 53. dissiliens (Dict.) 54. Ditmari (Pliys.) 277. dubium (Didy.) 244. dubium (Didy.) 246.

echinospora (Didy.) 239. echinulata (Stem.) 97. echimulatum (Lamp.) 97. effusa (Lind.) 41. effusa (Tubu.) 41. êfusum (Phys.) 313. effusum (Didy.) 236. elata (Crib.) 61.

elegans (Phys.) 313. elegans (Crib.) 55. elegans (Ener.) 105. elegans (Raci.) 108. elegantissimum (Didy.) 243. elegantula (Proto.) 128. ellipsosporum (Phys.) 310. Ellisiana (Lamp.) 98. epidendrum (Lyco.) 121. crecta (Trich.) 184.

erythrinum (Didy.) 275. erythrimum (Didy.) 249. exigium (Chon.) 240. eximium (Didy.) 241.

Fairmani (Didy.) 24.9. fallax (Licea) 47. fallax (Chon.) 212. fallax (Trich.) 192. Famintzini (Plıys.) 309. farinaceum (Didy.) 219. farinaceum (Dider.) 233. fasciculata (Badh.) 326. fasciculata ( $\beta$. $) 163$. fisciculatum (f.) 230 . fasciculatum (f.) 288. ferrnginea (Arcy.) 144. ferruginea (Stem.) 85. fimetarium (Phys.) 314. flagellifer (Proto.) 127. flagellifer (Derm.) 127. flagellifer (Trich.) 127. flagellifera (Proto.) 128. flavicomum (Didy.) 242. flavicomum (Phys.) 242. flavicomum (Phys.) 285. flavida (Peri.) 171.

flavidum (Diky.) 251. flavidum (Didy.) 251. flavidum (Pliys.) 247. flavidum (Didy.) 247. flavidum (Olig.) 171. flavo-fuscum (Lyco.) 124. flavo-virens (Phys.) 310. flavum (Phys.) 279. flexuosa (Tubu.) 37. flexuosa (Licea) 37. floriforme (Chon.) 308, 198. fuminensis (Stem.) 80. fragilis (Spha.) 176. fragilis (Trich.) 175 . fragilis (Trich.) 176. Friesiana (Coma.) 82. Friesiana (Stem.) 82. Friesiana (Peri.) 135. Friesianum (Chon.) 208. Friesii (Crat.) 266. Friesii (Arcy.) 152. Fuckeliana (Badh.) 321. Fuckeliana (Trich.) 321. Fuckelianum (Didy.) 222. Fuckelianum (Lamp.) 103. Fuckelii (Crat.) 272. fuliginea (Hemi.) 169. fuliginea (Arcy.) 169. fulvella (Badli.) 326. fulvellum (Didy.) 237. fulvipes (Didy.) 248. fulvum (Lepi.) 253. furcatum (Olig.) 173. fusca (Stem.) 72. fusca (Stem.) 88. fusca (Arcy.) 149. fusco-atra (Peri.) 115.

Gabriellae (Heter.) 140. gulbeum (Phys.) 296. geastroides (Clion.) 201. geastroides (Dider.) 201. 
glaucum (Didy.) 284. glaucum (Phys.) 284. globosum (Chon.) 206. glolosus (Lach.) 137. globuliferum (Phys.) 297. gracilenta (Tilm.) 330. gromulatum (Plyss.) 289. grunulifera (Badh.) 321. granuliferum (Dilly.) 321. Guaranitica (Tnbur.) 39. Guaranitica (Licea ?) 39. gyrocephala ('Tilm.) 335. gyrocephalum (D:dy.) 335. Iyrosum (Phys.) 307.

Hariotii (Arcy.) 155. herbatica (Stem.) 87. heterotrichia (Aric.) 17 . hians (Ailm.) $2 \pi 9$. hians (Phys.) 296. Hookeri (Diac.) 260. Hookeri (Dider.) 261. Hookeri (Lamp.) 261. humile (Didy.) 248. hyalina (Badh.) 319. hypnophilum (Didy.) 224. hyprophilum (Phys.) 314.

inaurata (Badh.) 324. incarnata (Arcy.) 145. incarnatus (Lach.) 139. inconspicue (Trich.) 180. imiturs (Phys.) 292. inaequalis (Phys.) 300. inermis (Arcy.) 157 . insignis (Arey.) 148. intermedia (Trich.) 188. intricata (Arcy.) 144. intricata (Crib.) 59. iridescens (Lamp.) 101. irideum (Lamp.) 95. irregularis (Badh.) 323. irregnlaris (Ophi.) 132. irregularis (Peri.) 133. irregularis (Arcy.) 146.

Jackii (Trich.) 188.

Kalbreyeri (Trich.) 191. Kalchbrenueri (Phys.) 297. Karsteni (Arcy.) 168. Kicksii (Trich.) 195. Kur:ii (Lepi.) 255. laciniatum (Dider.) 201. lateritia (Trich.) 176. laxa (Stem.) 79. laxa (Coma.) 79 . leicorpa (Hemi.) 167. leicorpa (Arcy.) 167. leocarpoides (Corn.) 167. leocarpoides (Arcy.) 167. Le prieurii (Arcy.) 153. leptotrichum (Chon.) 244. lencophaeum (Phys.) 288. leptotrichum (Didy.) 243. lercocephalum (Crat.) 267.

lencophaeum (Phys.), o. flexuosum, 287.

lencophacum (Phys.) 288.

levcopoda (Diac.) 259. leucopus (Phys.) 287.

lencosporum (Lamp.) 96.

Leveillei (Phys.) 296.

liccoides (Peri.) 118.

liceoules (Chon.) 215.

licheniformis (Spum.) 292.

lilacina (Badh.) 271.

lilaciunm (Crat.) 271.

Lindheineri (Licea) 42.

Lindheimeri (Tubur.) 42.

Listeri (Lamp.) 97.

Listeri (Didy.) 244.

livilum (Pliys.) 304.

lividum (Phys.) 294.

lobatum (Didy.) 220.

longa (Coma.) 83.

longa (Stem.) 83.

lomgipes (Didy.) 236.

Lorinseriana ( $\beta$. $) 175$.

lucidum (Dider.) 204.

lucidum (Chon.) 204.

luteolum (Phys.) 309.

luteo-valve (Phys.) 310.

Iyallit (Chon.) 201.

lycoperdi (Crib.) 104.

lycoperdon (Retic.) 93.

lycopodii (Lamp.) 104.

macrocarpa (Badh.) 317.

mucrocarpa (Crib.) 56.

macrocarpon (Phys.) 317.

macrosperma (Stem.) 76 .

macrospermum (Didy.) 228.

macrosporum (Enter.) 45 .

magna (Ballh.) 319.

magnum (Dicty.) 319.

mexime (Bref.) 91. 
maxima (Stem.) 74.

melanopesiza (Arcy.) 162. melanopeziza (Hemi.) 162. melanospora (Badh.) 325. melleum (Didy.) 278, 279. mellen (Didy.) 276, 278. metallica (Corn.) 130. metallica (Proto.) 128. metallica (Trich.) 128. metallicum (Phys.) 130. Michelii (Chon.) 204..Michelii (Dider.) 205. microcarpa (Badl.) 325. microcarpa (Crib.) 63. microcarpa (Peri.) 117. microcarpon (Didy.) 227. microcarpon (Didy.) 226. microcephala (Orth.) 109. microscopica (Crib.) 62. microsperma (Licea) 40. minima (Crib.) 59. minima (Tubu.) 36 . minima (Licea) 36. minima (Trich.) 182. minimum (Crat.) 272. minuta (Tilm.) 296. minuta (Tilm.) 279. minutissima (Crib.) 66. minutulum (Olig.) 171. minutum (Lamp.) 100. minutum (Echin.) 109. minutum (Lyco.) 125. minutum (Crat.) 264. minutum (Crat.) 273. mirabile (Heter.) 60. mirabilis (Crib.) 60 . mirabilis (Phys.) 334. Morgani (Stem.) 86. muscicolum (Phys.) 312. muscorum (Ener.) 106. muscorum (Phys.) 307. mutabile (Chon.) 212. mutabile (Crat.) 269. mutabile (Crat.) 272. mutabilis (Tilm.) 329.

mana (Trich.) 181. nefroideum (Pliys.) 285. neglectum (Didy.) 231. neglectum (Didy.) 224. nigrescens (Lamp.) 96. nigrescens (Lamp.) 102. nigripes (a.) 227. vitens (Badh.) 324. nitens (Ophi.) 133. nitens (Peri.) 133. nitens (Olig.) 170. nitens (Olig.) 173. nitens (Tricli.) 179. nitidissima (Tubu.) 30 . nitidum (Lyco.) 122. niverum (Chon.) 206. niven (Chon.) 207. nodulosa (Badh.) 322. nodulosum (Phys.) 322. nutans (Arcy.) 150. nutans (Crat.) 266. nutans (Tilm.) 327.

ob̉longa (Tilm.) $\mathbf{3 4}$. oblonga (Trich.) $3 \dot{i} 4$. obovatum (Lepi.) 254. obrusseum (Didy.) 241. obrusseum (Lidy.) 247. obrusseum (Didy.) 240. obrusseuin (Phys.) 241. ochraceum (Chon.) 216. ochraceum (Lyco.) 125. Oerstedtii (Chon.) 203. Oerstedtii (Crat.) 266. Oerstedtii (Arcy.) 147. olivaeeum (Enter.) 44. operiulata (Orca.) 49. ornatum (Phys.) 295. ovispora (Badh.) 326.

papaveracea (Badh.) 323. pallida (Badh.) 323. pallida (Peri.) 118. pallida (Ophi.) 136 pallidum (Steg.) 119. panicea (Badh.) 318. paniceum (Phys.) 318. pannorum (Licea) 118. papillata (Ener.) 105. paradoxa (Arcy.) 159. paradoxa (Hemi.) 160. Paraguayense (Didy.) 250. pedunculatum (Crat.) 264. penetralis (Badh.) 98 . perreptans (Licea) 91. pertusum (Didy.) 241. Petersii (Phys.) 295, 287. pexizoidenm (Didy.) 239. Phillipsii (Phys.) 290. physarioides (Chon.) 214. physarioides (Lamp.) 103. physarioides (Stem.) 96. 
physarioides (Didy.) 233. piceum (Phys.) 313. piriformis (Crib.) 55. platypus (Agaricus) 239. platypus (Didy.) 239. polyaedron (Phys.) 316. po'ymorphum (Phys.) 283. polymorphum (Pliys.) 251. pomiformis (Arcy.) 151. praccox (Didy.) 223. proximellu (Trich.) 180. proximum (Didy.) 238. pruinosum (Didy.) 288. psenuluecidium (Peri.) 119. psittacinum (Phys.) 274. pulchellı (Stem.) 86. pulchellar (Coma.) 86. pulcherrimum (Plyss.) 293. pulcherripes (Plyss.) 315. privice (Arcy.) 142. punicer (Arcy.) 149. puppurescens ('Trich.) 177. purpureu (C'rib.) 57. pusilla (Hemi.) 168. pusilla (Arcy.) 168. pusilln (Hemi.) 168. pusilla (Tricl.) 195. pusilla (Proto.) 44. pusillmu (Proto.) 44. presillum (Proto.) 43. pusillum (Dirly.) 238. pyriforme (Crit.) 264.

querciul (Peri.) 115.

Ruariborsckii (Arcy.) 156. ruliutum (Didy.) 229. rudiatum (C'hon.) 200, 202. Ravenclii (1)illy.) 281. Ravenelii (Phys.) 281. Realeri (Phivs.) 282. reniformis (Trieh.) 184. reniformis (Tiln.) 336 . reticuluta (Licea) 6is.3. reticulata (Licea) 1333. reticulata (Oplii.) 133. reticulata (Peri.) 133. reticulatum (Chon.) 216. reticulatum (Didy.) 253. reticulatum (Lepi.) 252. reticulatum (Phys.) 314. robusta (Lamp.) 99. roseum (Phys.) 294. liostrufinskii (Lach.) 138.
Rostafinskii (Peri.) 117. Rostafinskii (Phys.) 301. Rostrupii (Enter.) 45. Rozeana (Retic.) 47. Rozcaunm (Enter.) 47. vubiformis (Arcy.) 158. rubigirosa (Badh.) 270. mubiginosum (Crat.) 270. rubiginosum (Phys.) 302. rubiginosnem (Scyphium) 270. mefa (Crib.) 63.

rufibasis (Phys.) 296.

rufibasis (Phys.) 279.

rufipes $(\beta) 227$.

rufo-ciunamomentm (Lyco.) 125.

rugulosim (Clat.) 51.

Succardianum (Lamp.) 101.

Śanulersii (Chon.) 209.

Sauteri (Chon.) 217.

Sauteri (Lamp.) 100. scabra (Trich.) 192.

Schimperi (Lamp.) 99.

Schroeteri (Phys.) 280.

Schumacheri (Pliys.) 275.

Selumacheri (Phys.) 335.

Schumacheri (Phys.) 278.

Schweinitzii (Corn.) 52.

Schweinitzii (Phys.) 311. serobiculatum (Didy.) 301. scrobiculatum (Pnys.) 300. scyphoides (Phys.) 282. serpula (Arcy.) 164. serpula (Arcy.) 136. serpula (Didy.) 234. serpula (Ophi.) 135. serpuln (Hemi.) 165. simile (Phys.) 286. similis (Arcy.) 156 . simplex (Chon.) 217. simulans (Chon.) 209. simulaus (Enter.) 47. sinupisum (Didy.) 246. sinuosum (Phys.) 305. spadicemm (Ostr.) 52. speciosa (Tubu.) 38. splendens (Crib.) 62. splendens (Stem.) 74 . splendens (Diac.) 261. spermoides (Licea) 37. spermoides (Tubu.) 37. spumarioidea (Licea) 42. spumarioidea (Tubu.) 42. spumarioides (Dily.) 232. 


\section{Index.}

spumarioides (Chon.) 232. squamulosum (Didy.) 223. Stahlii (Chon.) 218. stellare (Dider.) 200. stellatum (Lepi.) 252. stipitata (Arcy.) 163. stipitata (Hemi.) 163. stipitata (Licea) 38. stipitata (Tubu.) 38. stipitata (Spor.) 219. stipitatum $\left(\gamma_{.}\right) 277$. straminiformis (Crib.) 335. striatum (Phys.) 243. stricta (Arcy.) 151. stromateum (Chon.) 233. subcaespitosa (Stem.) 80. subdictyospermum (Chon.) 208. subfusca ('Trich.) 183.

subglobosum (Phys.) 300. sublateritium (Chon.) 211. suboenerm (Lamp.) 95. subroseum (Didy.) 312. subsessitis (Diac.) 262. Suksdorfii (Coma.) 76 . Suksdorfii (Stem.) 76 . sulphurea (Trich.) 186. sulphureum (Phys.) 311. superba (Trich.) 194.

Tatrica (Crib.) 62. tenella (Crib.) 58. tenerrima (Stem.) 81. tenerrimum (Didy.) 247. tenuissina (Licea) 52. terrestre (Lyco.) 122. testacerem (Chon.) 210. tliyoteum (Phys.) 277. tigninum (Lepi.) 253. Trevelyana (Chon.) 202. Trevelyani (Leang.) 203. tubulina (Stem.) 87.

tussulaginis (Didy.) 244. tussulaginis (Phys.) 245. typhina (Coma.) 75. typhina (Stem.) 74.

umbrina (Arcy.) 147. umbrina (Ophi.) 135. utricularis (Badh.) 319.

vaccinum (Chon.) 217. vaccinum (Dider.) 217. vasia (Badh.) 319. varia (Trich.) 178. variabilis (Licea) 36 . venosum (Dict.) 68. vermiculare (Phys.) 135. vermicularis (Ophi.) 134 vermicularis (Peri.) 135. verna (Badh.) 324. vernicosa (Arey.) 142. verrucosa (Trich.) 191. versicolor (Arcy.) 149. versipelle (Didy.) 249. violacea (Lamp.) 95. violacerm (Lamp.) 94. virescens (Phys.) 277. virginenm (Var.) 226. viridis (Tilm.) 329. vitellina (Arcy.) 150. vitellinnm (Poly.) 311. vulgare (Crat.) 263. vulgaris (Crib.) 61.

Weinmanni (Didy.) 248. Wigandii (Arcy.) 163.

Wrightii- (Corn.) 132.

Wrightii (Opli.) 132.

Zeylanicum (Didy.) 240.

Zeylanicum (Chon.) 240. 
Ricilaro Clay \& Sonk, Limitri, IosDon \& Bl'vaY. 


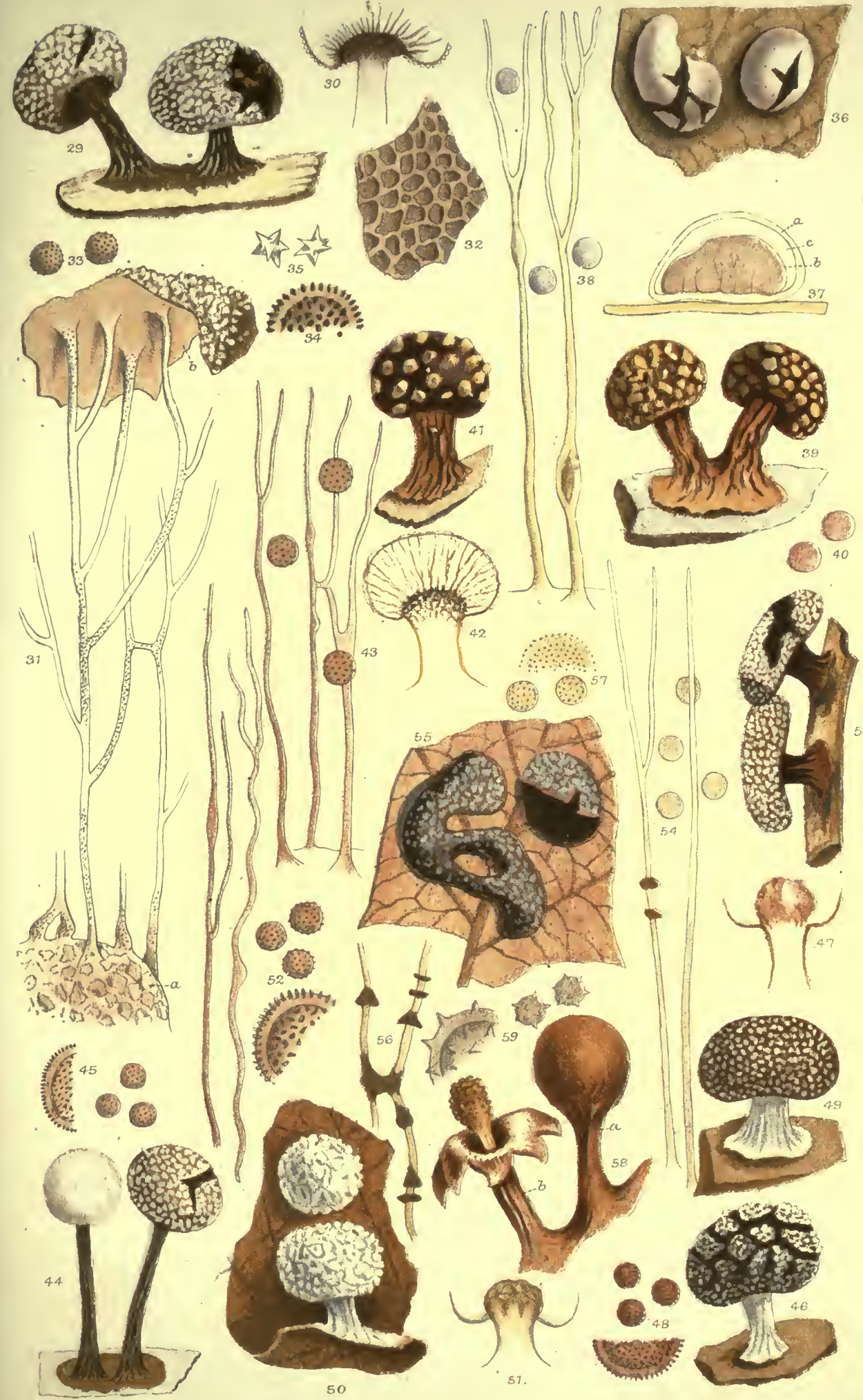


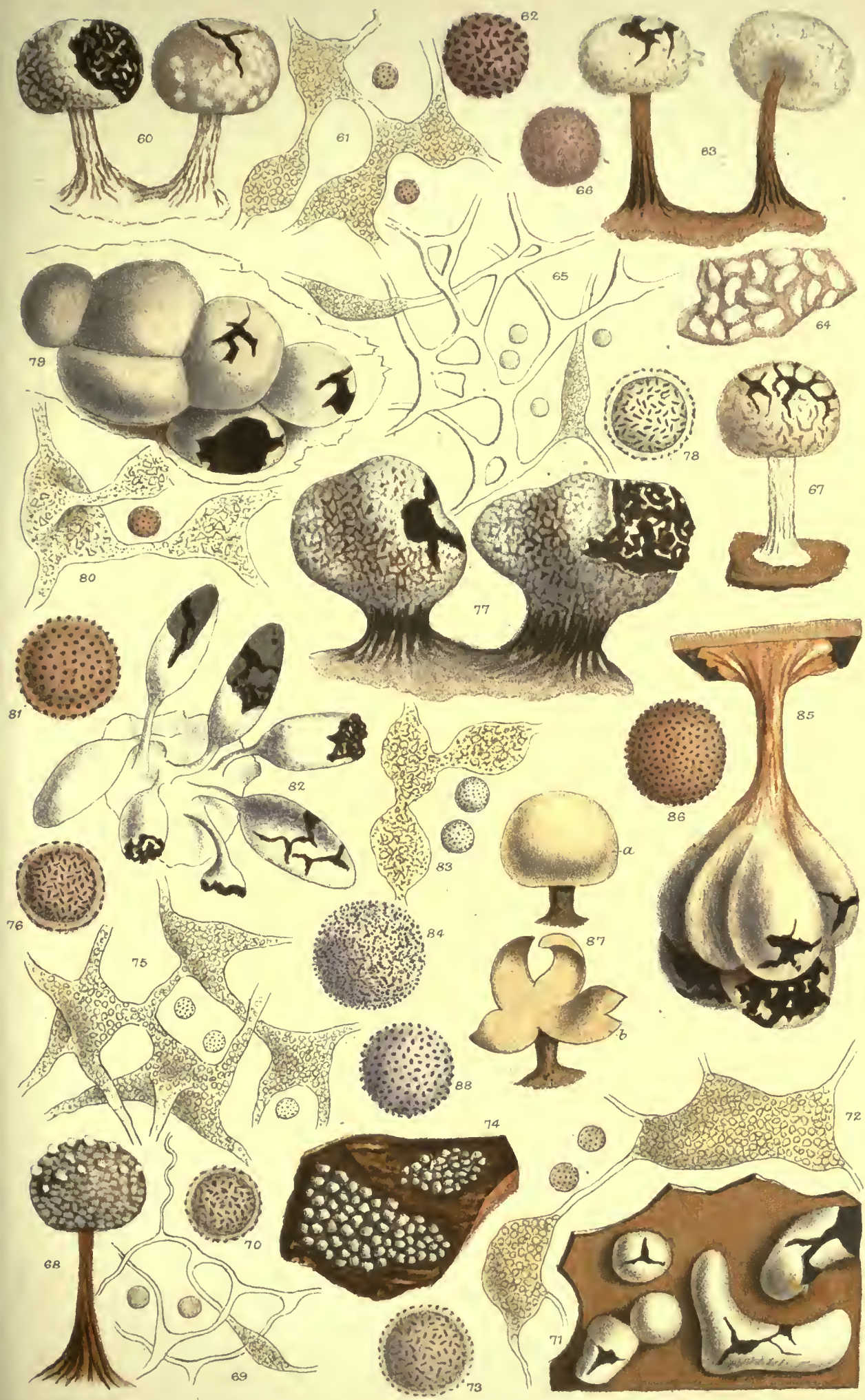




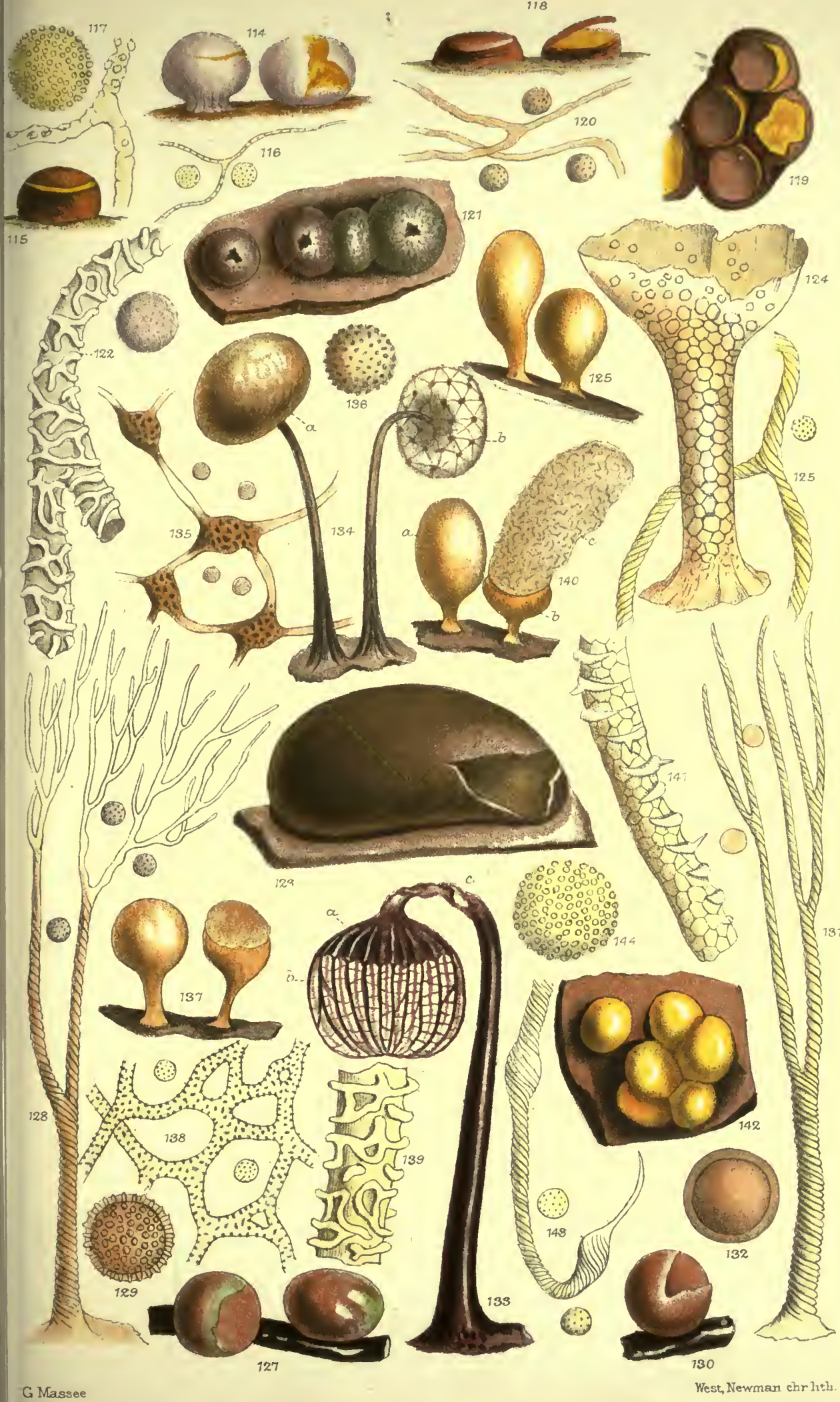




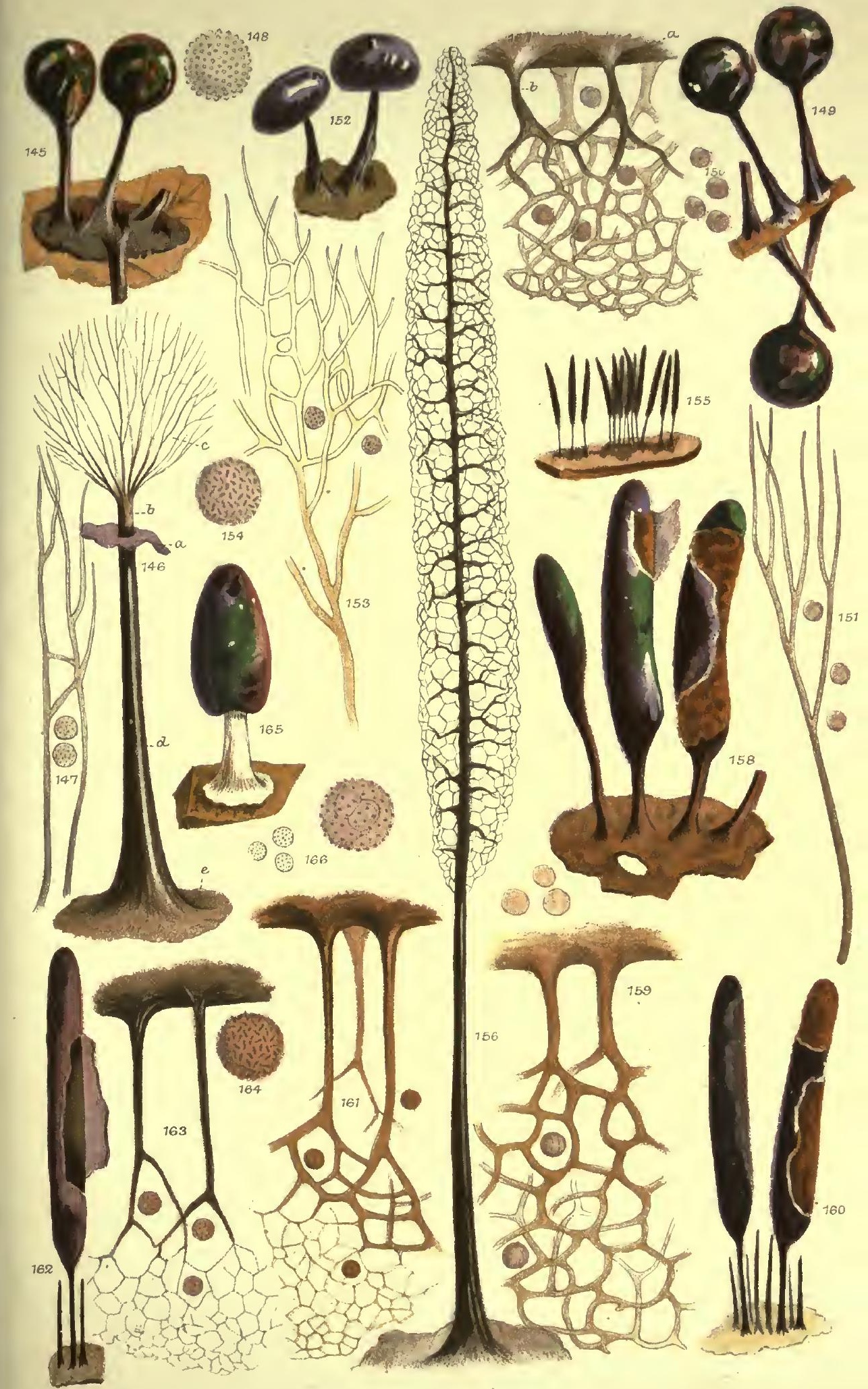



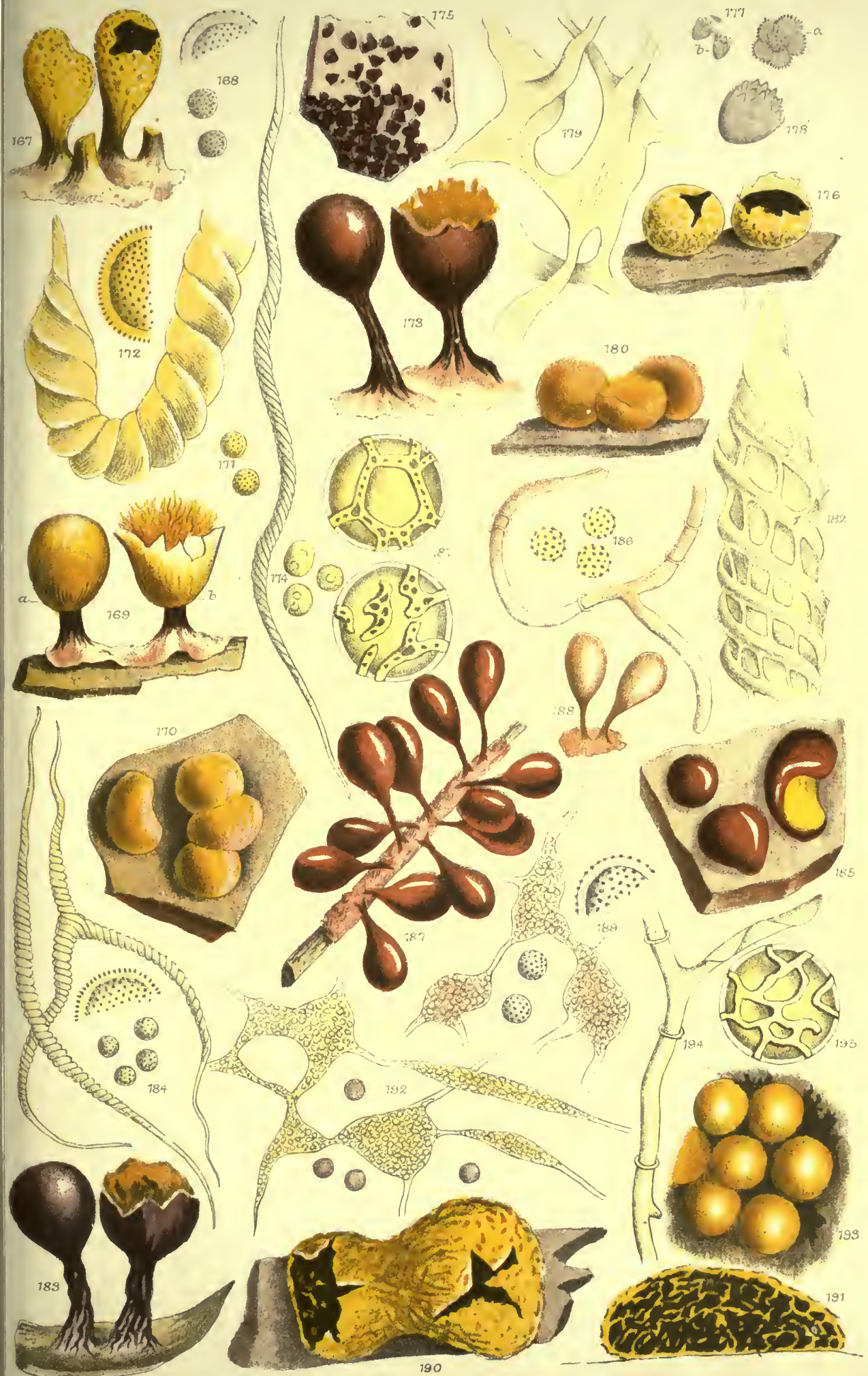




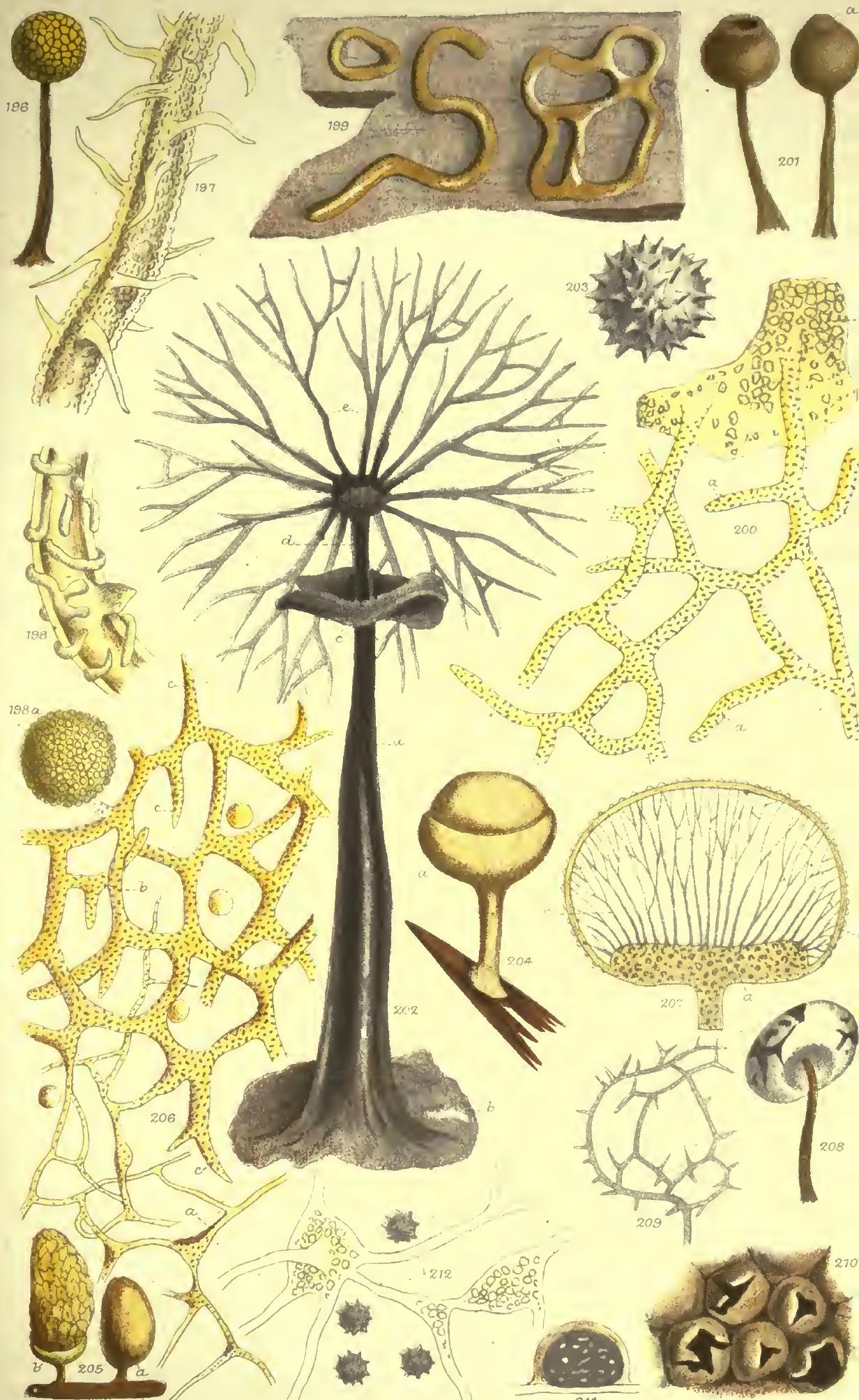



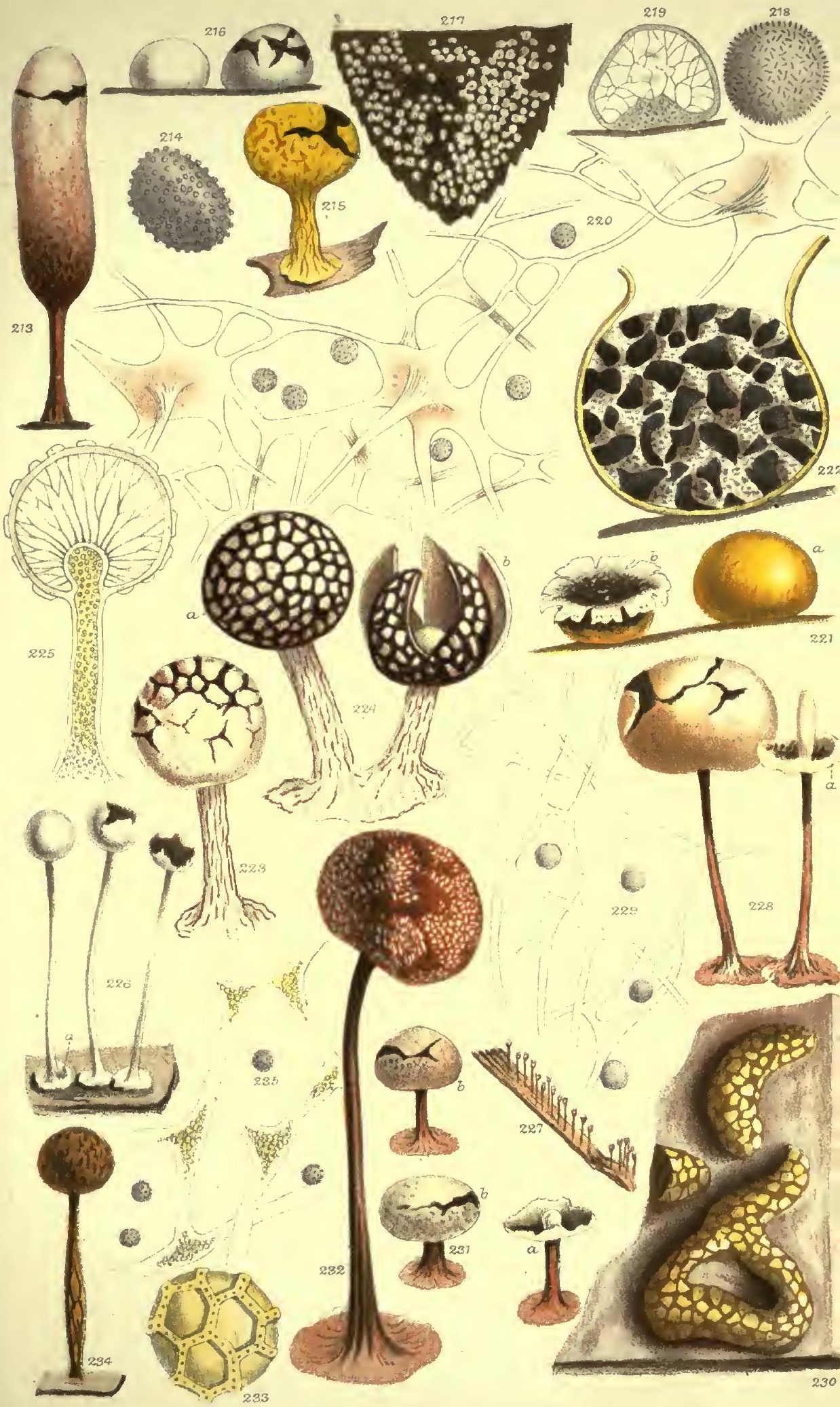





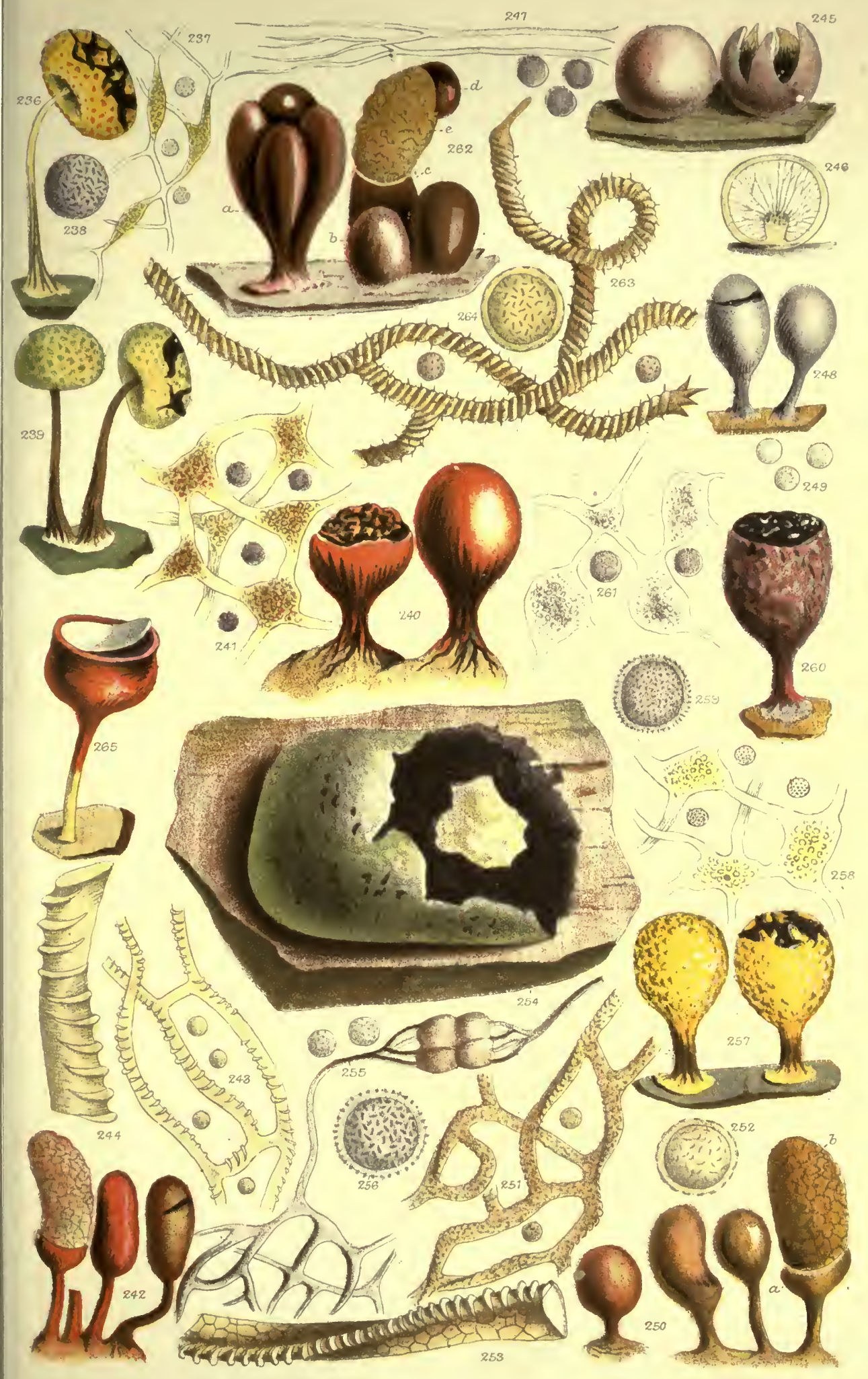





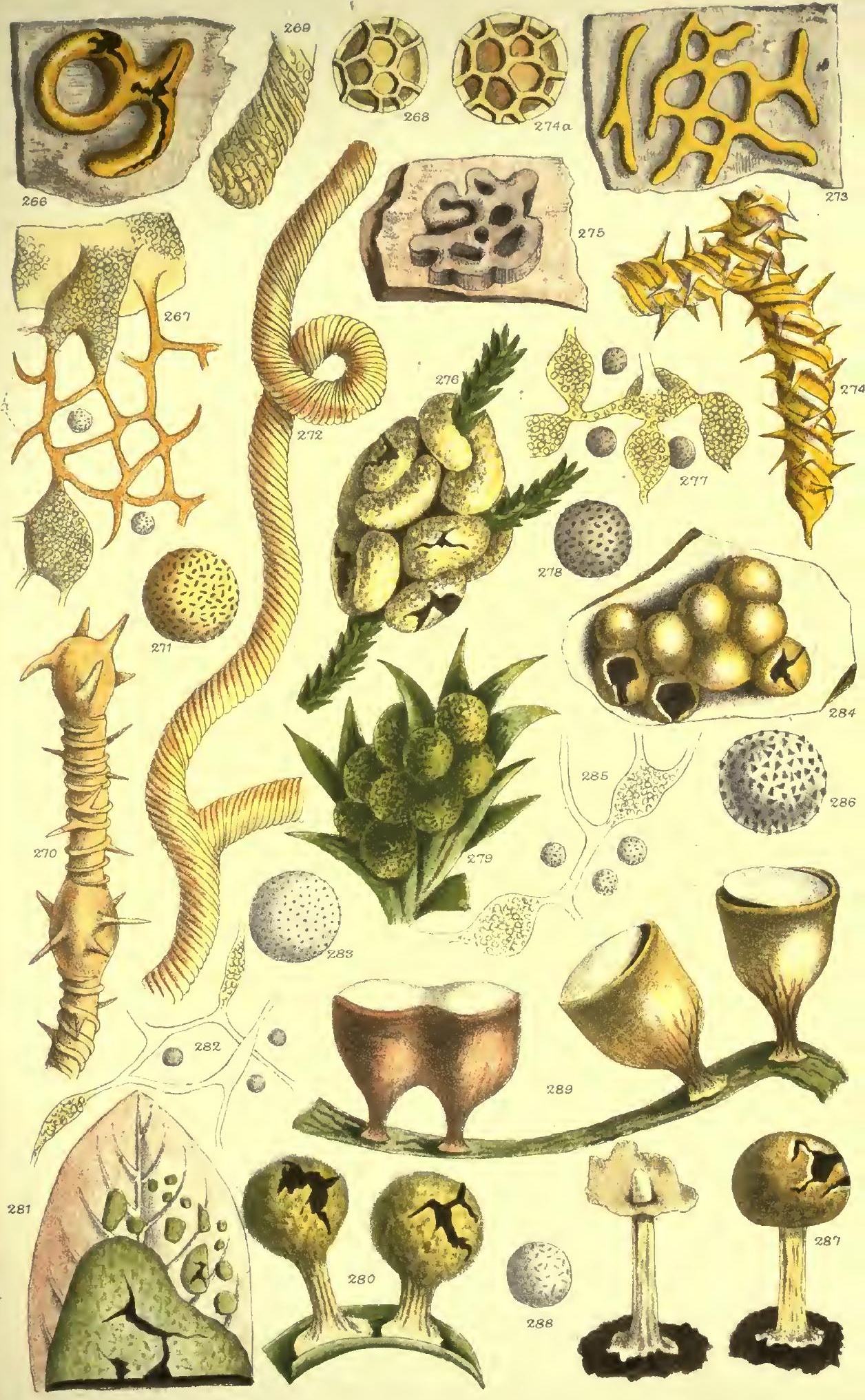




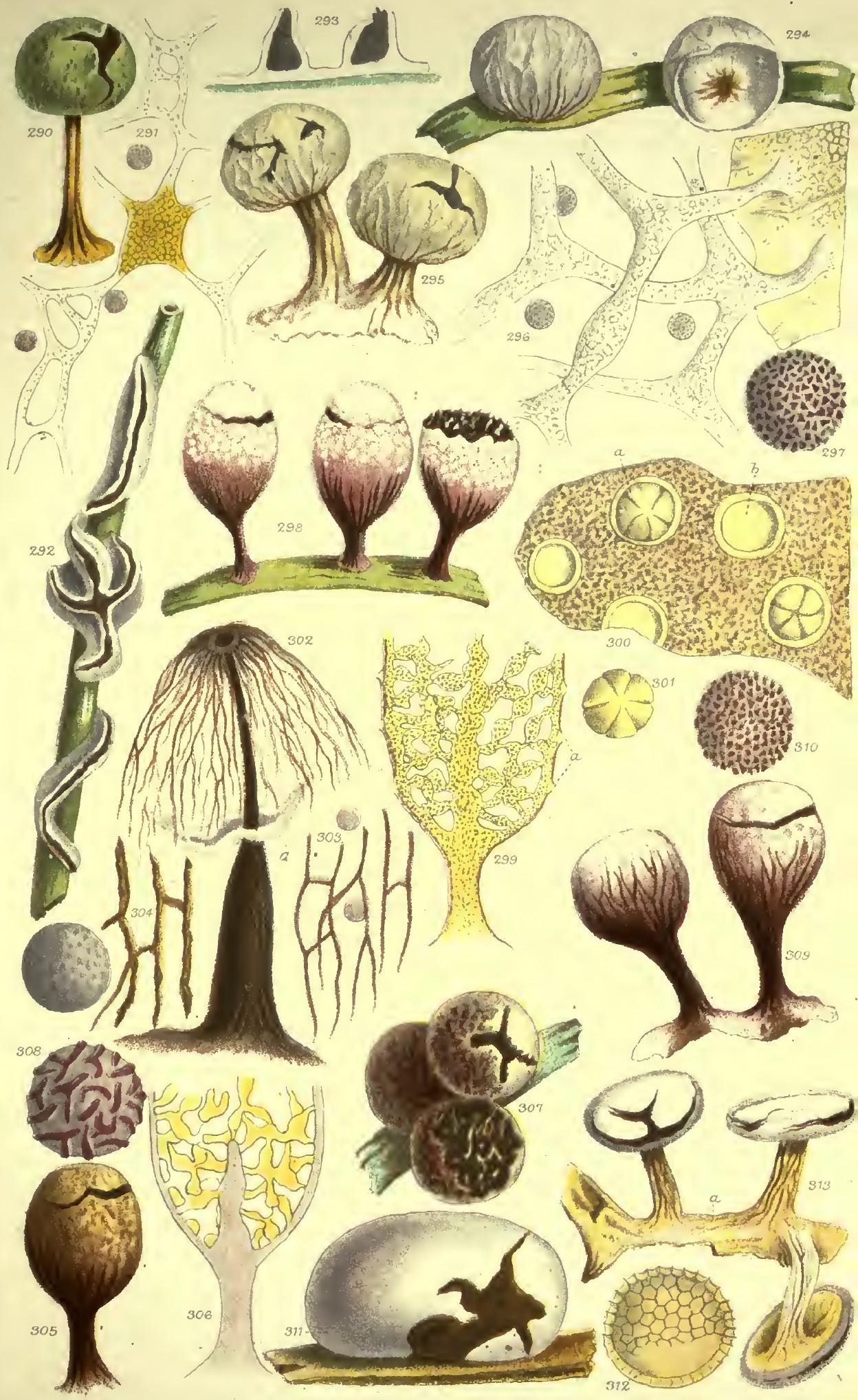


• 



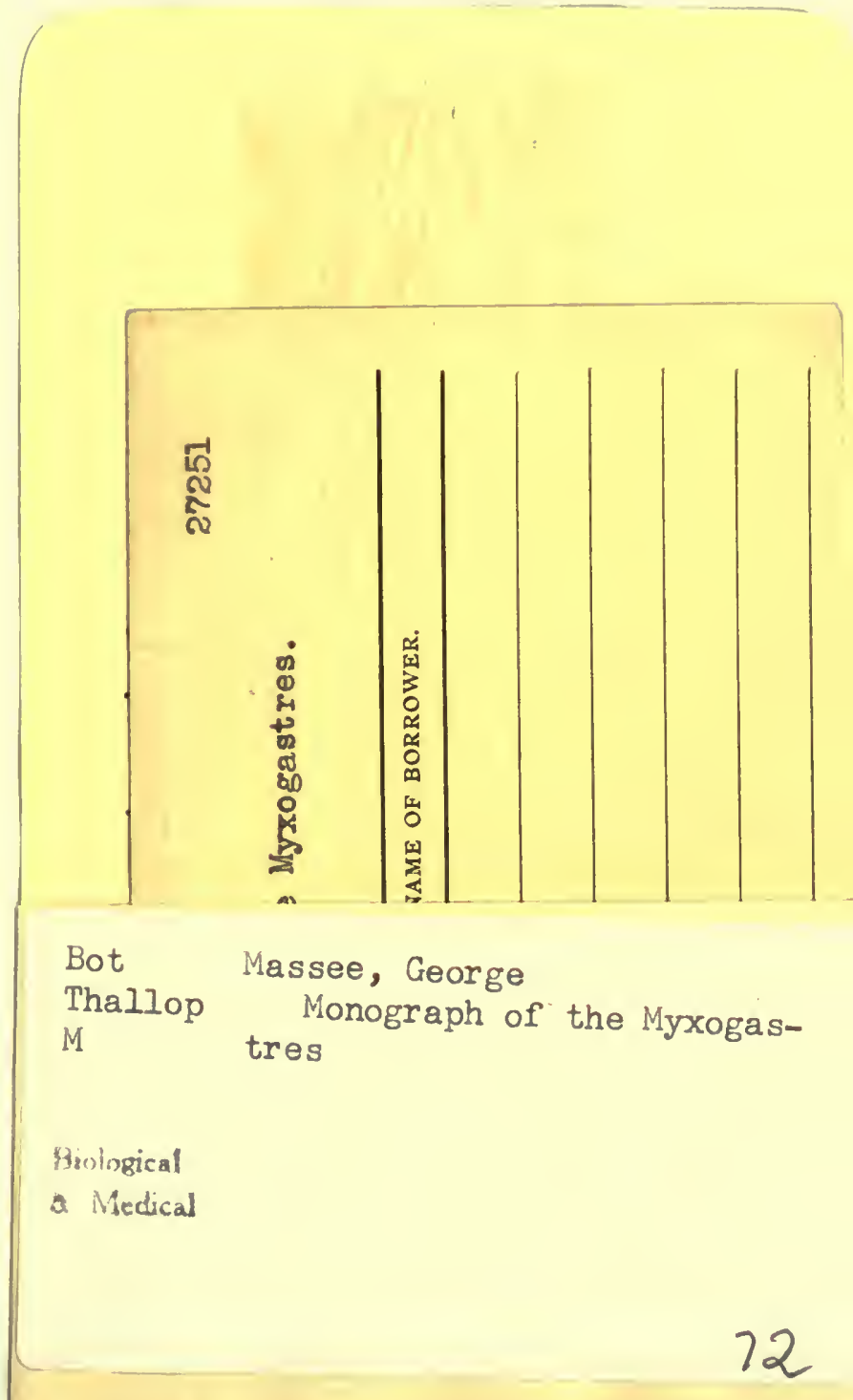


